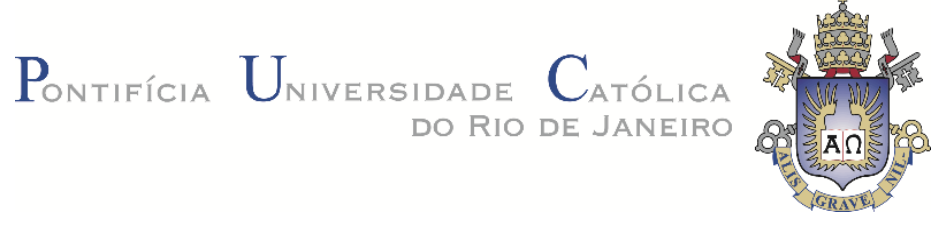

Flávia Pedrosa de Camargo

O Direito à Educação de Alunos com Deficiência: aspectos da implementação da política de educação inclusiva em Corumbá/MS

Tese de Doutorado

Tese apresentada ao Programa de Pós-Graduação em Educação da PUC-Rio como requisito parcial para obtenção do grau de Doutora em Ciências Humanas Educação.

Orientadora: Prof. Cynthia Paes de Carvalho Co-orientadora: Prof. Mônica de Carvalho Magalhães

Kassar

Rio de Janeiro

Fevereiro, 2019 
Flávia Pedrosa de Camargo

\section{O Direito à Educação de Alunos com Deficiência: aspectos da implementação da política de educação inclusiva em Corumbá/MS}

Tese apresentada como requisito parcial para obtenção do grau de Doutora pelo Programa de Pós-Graduação em Educação do Departamento de Educação do Centro de Teologia e Ciências Humanas da PUC-Rio. Aprovada pela Comissão Examinadora abaixo assinada.

Profa. Cynthia Paes de Carvalho

Orientadora

Departamento de Educação - PUC-Rio

Profạ. Mônica de Carvalho Magalhães Kassar

Co-orientadora

Universidade Federal de Mato Grosso do Sul

Profá. Flávia Faissal de Souza

Universidade do Estado do Rio de Janeiro

Profo. Murillo Marschner Alves de Brito

Universidade do Estado de São Paulo

Profa . Maria Luiza Canedo Departamento de Educação - PUC-Rio

Prof ${ }^{\mathrm{a}}$. Zena Winona Eisenberg

Departamento de Educação - PUC-Rio

Prof ${ }^{\mathrm{a}}$. Monah Winograd

Coordenadora Setorial do Centro de Teologia e

Ciências Humanas

PUC-Rio

Rio de Janeiro, 19 de fevereiro de 2019. 
Todos os direitos reservados. É proibida a reprodução total ou parcial do trabalho sem autorização da universidade, da autora e do orientador.

Flávia Pedrosa de Camargo

Graduou-se em Psicologia pela Universidade Federal de Mato Grosso do Sul em 2008. Concluiu o Mestrado em Educação no ano de 2011, pela mesma universidade. Na PUC-Rio, integra o grupo de pesquisa Gestão e Qualidade da Educação (GESQ), coordenado pela Profá. Cynthia Paes de Carvalho. É Psicóloga Organizacional do Instituto Federal de Mato Grosso do Sul, Campus Corumbá.

Ficha Catalográfica

Camargo, Flávia Pedrosa de

O direito à educação de alunos com deficiência aspectos da implementação da política de educação inclusiva em Corumbá/MS / Flávia Pedrosa de Camargo ; orientadora: Cynthia Paes de Carvalho ; co-orientadora: Mônica de Carvalho Magalhães Kassar. - 2019.

$208 \mathrm{f}$. $; 30 \mathrm{~cm}$

Tese (doutorado)-Pontifícia Universidade Católica do Rio de Janeiro, Departamento de Educação, 2019.

Inclui bibliografia

1. Educação - Teses. 2. Política de educação inclusiva. 3. Implementação. 4. Burocracia de médio escalão. 5. Burocracia de nível de rua. 6. Capacitismo. I. Carvalho, Cynthia Paes de. II. Kassar, Mônica de Carvalho Magalhães. III. Pontifícia Universidade Católica do Rio de Janeiro. Departamento de Educação. IV. Título. 
Às pessoas com deficiência que vivenciam diariamente situações de invisibilidade. 


\section{Agradecimentos}

Aos meus pais, Vilma e Manoel por tudo o que me proporcionaram durante toda a minha trajetória. A eles devo tudo o que sou.

À minha irmã Fabiana, por ter sido minha segunda mãe e grande responsável por todas as minhas conquistas.

Ao meu esposo Leandro, por estar sempre ao meu lado e ser o melhor parceiro que eu poderia ter.

Às minhas orientadoras, $\operatorname{Prof}^{\mathrm{a}}$. Cynthia e Prof ${ }^{\mathrm{a}}$. Mônica a quem tive a grande honra de conviver mais de perto, compartilhar experiências e, principalmente, crescer como profissional e ser humano, tendo como exemplo mulheres espetaculares e extremamente humildes e solícitas. A vocês, o meu sempre muito obrigada!

À banca pelas importantes contribuições no trabalho.

À UFMS Campus do Pantanal, na pessoa do Prof ${ }^{\circ}$. Fabiano Santos e da Prof ${ }^{a}$. Mônica Kassar por terem proporcionado a oferta de um Dinter entre a UFMS e a PUC-Rio.

À PUC-Rio por todo o apoio prestado durante toda a trajetória, principalmente durante os meses em que permanecemos no Rio de Janeiro.

À todos os professores do Departamento de Educação da PUC-Rio, os meus singelos agradecimentos pela oportunidade de aprender com profissionais competentes e respeitáveis.

Ao GESQ pelas excelentes contribuições na tese, em especial à Carla Lima, pelo grande companheirismo durante a fase final desta trajetória e Ana Cristina Prado de Oliveira pelas contribuições na Qualificação II.

Ao Instituto Federal de Mato Grosso do Sul, Campus Corumbá pelo apoio e incentivo.

Aos meus amigos e amigas, que acompanharam de perto todo o trajeto e com muito carinho desejaram sempre muito sucesso durante toda essa caminhada.

À Secretaria Municipal de Educação de Corumbá e principalmente ao CMADIJ e às escolas da rede, por terem me recebido tão bem e contribuído com a realização do trabalho

À FUNDECT pelo apoio financeiro concedido para realização das viagens para as qualificações e defesa. 


\section{Resumo}

Camargo, Flávia Pedrosa de. Paes de Carvalho, Cynthia . O Direito à Educação de Alunos com Deficiência: aspectos da implementação da política de educação inclusiva em Corumbá/MS. Rio de Janeiro, 2019. 208 p. Tese de Doutorado Departamento de Educação, Pontifícia Universidade Católica do Rio de Janeiro.

O trabalho buscou investigar a implementação das políticas da educação inclusiva na rede municipal de Corumbá/MS a partir das percepções dos agentes implementadores. Como objetivos específicos buscamos conhecer como as políticas educacionais voltadas aos alunos com deficiência são implementadas no município e quais as condições de atendimento desses alunos na rede municipal. Focalizamos em particular a interação entre a gestão das escolas com a Secretaria Municipal de Educação e a maneira como ocorrem os atendimentos voltados aos alunos com deficiência, considerando a atuação da gestão e professores das unidades escolares. Como referencial teórico utilizamos os estudos sobre burocracia de médio escalão e de nível de rua, para entendermos como essas relações se estabelecem. Utilizamos também o contexto histórico das políticas da educação especial para entendermos de que maneira elas se consolidam na sociedade brasileira, além dos Estudos sobre a Deficiência (Disability Studies) que nos ofereceram condições de chaves de interpretação dos fenômenos por meio da perspectiva sociológica da deficiência, sobretudo através do conceito de Capacitismo. Inicialmente foi aplicado um survey às equipes de gestão e aos professores de todas as escolas urbanas da rede municipal de Corumbá, totalizando dezesseis unidades escolares. A partir da análise dos dados coletados e dos microdados do Censo Escolar 2016 foram escolhidas três escolas para participar de um movimento posterior de pesquisa qualitativa. Esta fase qualitativa incluiu cerca de um mês de observação do cotidiano em cada escola e entrevistas semiestruturadas realizadas com oito integrantes das equipes de gestão e dez professores. Esta segunda fase da pesquisa foi completada com a análise de documentos oficiais e seis entrevistas semiestruturadas com profissionais da Secretaria Municipal de Educação. Os resultados mostraram que os agentes 
implementadores das políticas da educação inclusiva, apesar de seus esforços para realização do trabalho, encontram dificuldades que interferem diretamente em sua atuação. O funcionamento precário de algumas unidades escolares, a pressão de responsabilização quanto aos resultados sem a oferta de condições adequadas de trabalho, o desmantelamento nos últimos anos da equipe pedagógica responsável pelo atendimento dos alunos com deficiência da rede municipal são fatores que impactam profundamente no trabalho desses profissionais. Atrelado a isso ressaltamos também as percepções desses agentes implementadores a respeito do conceito de deficiência e o fato da maior parte deles considerar os alunos com deficiência como incapazes. Este conjunto de fatores contribui para os resultados encontrados no Censo Escolar, que mostram que esses alunos, embora acessem à escola regular, no marco da política de inclusão educacional em vigor, encontramse majoritariamente retidos nos anos iniciais do Ensino Fundamental, raramente completando as condições para sua efetiva inclusão escolar e social.

\section{Palavras-chave}

Política de Educação Inclusiva; Implementação; Burocracia de médio escalão; Burocracia de nível de rua; Capacitismo. 


\section{Abstract}

Camargo, Flávia Pedrosa de. Paes de Carvalho, Cynthia (advisor). Students with Disabilities Right to Education: aspects of the implementation of the policy of inclusive education in Corumbá/MS. Rio de Janeiro, 2019. 208 p. Tese de Doutorado - Departamento de Educação, Pontifícia Universidade Católica do Rio de Janeiro

The work sought to investigate the implementation of public policies of special education in the municipal system of Corumbá / MS based on the perceptions of the implementing agents. As specific objectives, we wanted to learn how educational policies aimed at students with disabilities are implemented in the municipality and what the conditions of attendance of these students are in the municipal system. We focused particularly on the interaction between the school board with the Municipal Department of Education, and the way the service to the disability students is provided considering the operation of the school management and teachers. As a theoretical framework, we use studies on middle-level and street-level bureaucracy to understand how these relationships are established. We also used the literature on the historical context of special education policies to understand how they were consolidated in Brazilian society, in addition to Disability Studies, which offered us keys to interpret phenomena through the sociological perspective of disability, especially throughout the Ableism concept. Initially a survey was applied to the management teams and teachers of all urban schools of the municipal system of Corumbá, summing sixteen school units. From the analysis of data collected and the microdata of the 2016 Brazilian School Census, three schools were chosen to participate in a following movement of qualitative research. This qualitative phase included about a month of observation of the daily life in each school and semistructured interviews done with eight members of the management team and ten teachers. This second phase of research was than complemented with official documents' analysis and six semi-structured interviews with professionals from the Municipal Education Department. The results showed that the agents implementing the policies of the special education, despite their efforts to carry out the work, find difficulties that interfere directly in their work. The precarious functioning of some 
school units, the pressure to hold the principals' accountable for the school results, without the provision of adequate work conditions, and the dismantling in the last years of the educational team responsible to provide the service to the students with deficiency of the municipal system, are factors that impact the work of the professionals at school level. In addition to that we highlighted the perceptions of the implementing agents to the concept of disability and the fact of the majority of them considers disability students as unable. This set of factors contributes to the results found in the School Census that show that these students, although they attend the regular school, within the framework of the current policy of educational inclusion, are mostly retained in the initial years of Elementary Education, rarely completing the conditions for effective school and social inclusion.

\section{Keywords}

Policy of Inclusive Education; Implementing; Middle-level bureaucracy; streetlevel bureaucracy; Ableism. 


\section{Sumário}

Introdução

1.Políticas Educacionais para Pessoas com Deficiência:

história, perspectivas e implementação

1.1.Discussões a partir da Perspectiva Sociológica

sobre a Deficiência

1.2. A Influência das Organizações Internacionais nas Políticas

da Educação Especial

28

1.2.1.O Período Entre 1960 A 1980

1.2.2. A municipalização da educação a partir da Constituição Federal de 1988 e as políticas educacionais na década de 1990

1.2.3. As Políticas da Educação Especial na Perspectiva da Educação Inclusiva a partir dos anos 2000

1.3. A Implementação das Políticas Educacionais e

Discricionariedade dos Agentes Implementadores

1.3.1.Os Agentes Implementadores: a discricionariedade dos

burocratas de médio escalão e dos burocratas de nível de rua

2. O Campo da Pesquisa: a Rede Municipal de Ensino de Corumbá e a Educação Voltada às Pessoas com Deficiência.

2.1. A Rede Municipal de Ensino de Corumbá/Ms:

o recorte da pesquisa

2.2. A Educação Especial Na Rede Municipal De Corumbá/MS

2.3.Os Fenômenos que Emergem dos Discursos: uma análise inspirada na perspectiva hermenêutico-dialética

3. A Política de Educação Especial na Perspectiva da

Educação Inclusiva em Corumbá: perspectivas dos agentes implementadores da Secretaria Municipal De Educação

3.1.O Contexto de Criação do Cmadij, Formulação de

Políticas Públicas e os Burocratas de Alto Escalão:

disputas em ação 
3.2. Interações dos Agentes Implementadores no Âmbito da Secretaria Municipal De Educação

3.2.1. A Atuação da Supervisão do Núcleo de Inclusão Escolar e

Diversidade

3.2.2. O Trabalho Das Assessoras Técnicas Do Cmadij

4. A Implementação da Política de Educação Especial na

Perspectiva dos Agentes Implementadores no Âmbito

das Escolas

113

4.1.A Pesquisa em Corumbá: aplicação do survey e

estudos em escolas

4.2. A Pesquisa Empírica: observações e entrevistas nas três unidades escolares

4.2.1. A Escola II

4.2.2. A Escola IX

132

4.2.3. A Escola IV

136

4.3. As Percepções sobre a Deficiência: como as pessoas com deficiência são enxergadas pelos implementadores das políticas públicas

4.4.Percepções a Respeito do Conceito de Deficiência e Educação Inclusiva: a escola que acolhe

4.4.1 A Formação Continuada dos Agentes Implementadores e sua Atuação no Âmbito da Escola

4.5. A Implementação da Política no Âmbito da Gestão Escolar: atuação dos diretores e coordenadores

4.6.Burocratas de Nível de Rua: interações entre os agentes implementadores da linha de frente

5. Considerações Finais

6. Referências Bibliográficas

7. Anexos

8. Apêndices 


\section{INTRODUÇÃO}

A motivação para a realização do presente trabalho é de longa data. Para mim, a educação especial sempre foi um objeto de estudos instigante, sendo meu foco de pesquisa desde os anos finais da graduação em Psicologia na Universidade Federal de Mato Grosso do Sul (UFMS), Campus do Pantanal (2008). Após a formação no ensino superior, atuei por dois anos na Associação de Pais e Amigos dos Excepcionais ${ }^{1}$ (APAE), onde estagiei durante a graduação. Minha atuação era voltada, dentre outras funções, à inserção dos alunos da turma de "Qualificação para o Trabalho" no mercado de trabalho. No ano de 2009, entrei para o mestrado em Educação, na UFMS Campus do Pantanal, pesquisando a relação do Benefício de Prestação Continuada (BPC) com a inserção das pessoas com deficiência intelectual no mundo do trabalho ${ }^{2}$. Atualmente atuo como psicóloga organizacional no Instituto Federal de Educação, Ciência e Tecnologia de Mato Grosso do Sul, Campus Corumbá onde coordeno o Núcleo de Apoio à Pessoa com Necessidades Educacionais Específicas (NAPNE).

No contexto da história da educação especial no Brasil, as escolas especializadas de caráter assistencial - via de regra filantrópicas - ocupam um lugar relevante, recebendo recursos públicos a partir de convênios, apesar da existência de instituições públicas que realizam atendimento educacional às pessoas com deficiência desde o período imperial (Instituto Nacional de Educação de Surdos INES e Instituto Benjamin Constant). Como assinala Kassar (2001):

\footnotetext{
As instituições "privadas", principalmente no setor do atendimento especializado a pessoas com deficiências, vão se apresentar durante toda a história da Educação Especial como extremamente fortes, com lugar garantido no discurso oficial, chegando a confundir-se com o próprio atendimento "público" aos olhos da população, pela "gratuidade" de alguns serviços (p. 29, grifos da autora).
}

\footnotetext{
${ }^{1}$ Instituição privada de caráter assistencial.

${ }^{2}$ CAMARGO, F.P. O Benefício de Prestação Continuada e a inserção do indivíduo com deficiência intelectual no mundo do trabalho. Dissertação de Mestrado. UFMS, Programa de Pós-graduação em Educação, Campus do Pantanal. Corumbá, 2011.
} 
Um contraponto importante refere-se ao caráter filantrópico de tais instituições. Kassar (2001) chama a atenção para a transferência da responsabilidade do poder público para a sociedade civil por meio de um discurso que prioriza ações assistencialistas e filantrópicas.

$\mathrm{O}$ atendimento educacional voltado às pessoas com deficiência, ganha espaço nas legislações de âmbito nacional a partir da Lei de Diretrizes e Bases de 1961, que reconhece a educação dos "excepcionais" com a indicação de sua matrícula "dentro do possível” na rede regular de ensino (KASSAR, 2011a p. 44 grifos da autora). A partir daí, diversos fatores influenciaram a criação de políticas educacionais para pessoas com deficiência, principalmente nos anos de 1990 (após a Constituição de 1988) e início dos anos 2000, conforme veremos mais adiante.

Retomando o percurso da pesquisadora, anos depois, já atuando no IFMS Campus Corumbá (a partir de 2011), convivi com uma situação distinta, ao trabalhar em uma escola que possui como exigência a aprovação em um processo seletivo. Ou seja, adentram aqueles que apresentam as melhores notas na seleção. Curiosamente, não tínhamos nenhum aluno com deficiência matriculado. Assim, os questionamentos referentes às condições de acesso desses alunos às instituições de ensino continuavam gerando inúmeras dúvidas. Diante disso, a partir da entrada no Programa de Pós-graduação em Educação da PUC-Rio, por meio da oferta de um Doutorado Interinstitucional (Dinter) em parceria com a UFMS propus um projeto que buscava entender como as condições sociais influenciavam a trajetória dos alunos com deficiência na escola.

Ao analisarmos os microdados do Censo Escolar do ano de 2014, inicialmente, verificamos que poucos alunos com deficiência conseguiam concluir o Ensino Fundamental, permanecendo, em sua maioria, nos primeiros anos desta etapa escolar. Dessa forma, o estudo referente às trajetórias seria inviabilizado pelo fato de que, a maior parte dos alunos encontrava-se retida nos anos iniciais do ensino fundamental. A retenção dos alunos com deficiência configurou-se como a problemática da pesquisa, uma vez que, a partir do levantamento dessa informação voltamos nossos olhares para as possíveis situações que poderiam contribuir para essa realidade. 
A partir da inserção no grupo de pesquisa Gestão Escolar e Qualidade na Educação (GESQ), novas questões se apresentaram em torno do que seria o papel da gestão escolar nos processos de inclusão escolar previstos nas políticas em vigor. Estudos que apresentavam a gestão escolar, a liderança do gestor e outros aspectos ligados à figura do diretor e de sua equipe como um dos principais determinantes para o acesso e permanência com sucesso dos alunos (PAES DE CARVALHO, OLIVEIRA e LIMA, 2014; OLIVEIRA, 2015; LIMA, 2016) mostraram que este tema poderia nos responder muitos dos questionamentos existentes no campo da Educação Especial.

O campo de pesquisa da educação especial esteve voltado nos últimos anos para a investigação da educação escolar das pessoas com deficiência, bem como as análises da natureza e função da educação especial. É o que apontam Bueno e Souza (2018) ao realizarem um levantamento das publicações da Revista Brasileira de Educação Especial. Das produções voltadas à educação especial e divulgadas no periódico entre os anos de 1997 e 2017, 23,7\% abordaram o tema da prática docente, 14,8\% investigaram a formação do professor, 14,8\% a identidade da educação especial, $13,9 \%$ as políticas e $12,3 \%$ a produção de pesquisa no campo. Os autores apontam que as demais publicações apresentaram resultado inexpressivo e são compostas por textos voltados a aspectos referentes à inserção social.

A respeito das pesquisas que vinculam a educação especial à gestão escolar, Ferreira e Bueno (2011), ao realizarem levantamento das publicações do Grupo de Trabalho da Educação Especial na Associação Nacional de Pesquisa em Educação (ANPED) de 1992 a 2010, apontam uma baixa incidência do tema nos trabalhos $(7,9 \%$, sendo utilizado o termo educador para designar as pesquisas que utilizaram diretores, gestores, coordenadores e outros profissionais de educação). Praticamente quatro quintos das produções foram voltadas a documentos, professores e alunos, com destaque para os dois primeiros.

É possível verificar que o campo de pesquisa da educação especial, na sua construção, voltou seu olhar, principalmente para as questões que envolvem o professor, tendo poucas publicações que analisam outros agentes do contexto escolar. 
A investigação que toma como foco a figura do gestor escolar é de grande valia no campo das pesquisas da educação de maneira geral e na educação inclusiva, em especial. A esse respeito, Flores (2018) afirma:

\begin{abstract}
A atuação da gestão escolar é indispensável em todos os setores da escola, faz-se necessária e imprescindível prioritariamente quando os desafios são maiores, como no caso das questões relacionadas à educação inclusiva. Por apresentar inúmeras dificuldades quer seja de estrutura física, ordem material, ou preponderantemente nos quesitos de formação profissional e de relações estabelecidas, essas dificuldades acabam por trazer lacunas perceptíveis, que não podem ser naturalizadas na escola, contrariamente devem ser objeto de discussão tendo como meta o acesso, a permanência de todos os alunos (p.70).
\end{abstract}

Flores (2018) realizou levantamento das publicações que integram a temática da educação inclusiva e gestão escolar no período de 2007 a 2017 na Biblioteca Digital Brasileira de Teses e Dissertações (BDTD), Instituto Brasileiro de Informação em Ciência e Tecnologia (IBICT) e no Sistema Integrado de Bibliotecas da Universidade de São Paulo (SIBiUSP). A autora verificou que entre o período de 2008 e 2015 foram publicados apenas seis trabalhos, sendo quatro dissertações e duas teses que discutiram a temática da educação inclusiva, educação especial, prática pedagógica, práticas inclusivas e gestão escolar.

Guerreiro (2012) aponta que não bastam apenas adequações de espaço físico para garantir a permanência de alunos com deficiência na escola, mas é preciso que sejam realizadas adequações de recursos pedagógicos e a capacitação do corpo docente e gestor. Somamos a essa afirmação, o fato de que as percepções dos gestores e professores sobre a deficiência também devem ser consideradas, pois elas podem ser primordiais nos processos de implementação das políticas educacionais voltadas a esses atores.

Ao verificarmos a escassez de publicações que articulam os temas da gestão escolar e da educação especial na perspectiva da educação inclusiva apresentamos a pesquisa realizada. O olhar voltado ao gestor foi referenciado pelos conceitos que abordam a discricionariedade dos burocratas de médio escalão (BME) e dos burocratas de nível de rua (BNR). Os burocratas de médio escalão consistem nos "gerentes, dirigentes, supervisores e agentes encarregados de operacionalizar as estratégias definidas nos altos escalões da burocracia, porém, distanciados dos contextos concretos de implementação" (PIRES, 2011 p.3). Já os burocratas de nível de rua são os "funcionários que trabalham diretamente no 
contato com os usuários dos serviços públicos, como, por exemplo, policiais, professores, profissionais da saúde, entre outros" (LOTTA, 2014 p.43).

Dessa forma, neste trabalho os agentes implementadores no âmbito da secretaria municipal de educação e os diretores e coordenadores das escolas serão considerados agentes híbridos, conforme definido por Mota (2018) que afirma que esses atores possuem multiplicidade de funções, atuando hora como burocratas de médio escalão, hora como burocratas de nível de rua, a depender do público com quem interagem. Já os professores regentes, professores do atendimento educacional especializado (AEE) e profissionais de apoio serão considerados os burocratas de nível de rua, neste trabalho, definidos como os agentes públicos que interagem diretamente com os cidadãos e que tem substancial descrição na execução do seu trabalho (Lipsky, 2010).

A literatura que analisa a implementação de políticas com o olhar voltado para os agentes implementadores ainda é bastante incipiente no campo das pesquisas. Lotta, Pires e Oliveira (2015) apontam que, em âmbito nacional, existe uma limitação da literatura em relação ao olhar dado ao papel das diferentes burocracias no processo entre formulação e implementação. A respeito da burocracia intermediária os estudos são ainda mais escassos. Ainda assim, Faria (2012) aponta que as pesquisas que possuem como tema a implementação de políticas públicas no Brasil apresentaram crescimento considerável apenas a partir dos anos 2000. Segundo o autor, dentre aquelas realizadas no âmbito de programas de pós-graduação entre 1987 e 2010 a maior parte constituiu-se de estudos na área da Educação, seguido do Direito e da Saúde.

No campo da implementação de políticas públicas é importante destacar os aspectos ligados à descentralização, marcados no Brasil, sobretudo, a partir da Constituição de 1988. Cavalcante (2011) afirma que a literatura voltada à descentralização de políticas aborda o processo descentralizador brasileiro a partir da dinâmica das relações intergovernamentais. Consequentemente, os fatores de ordem institucional como as normas constitucionais, regras eleitorais e de funcionamento das relações federativas permeiam o estudo do campo no país. O autor destaca a necessidade de estudos que considerem a compreensão dos 
processos decisórios, seus impactos e os resultados subjacentes à implementação de políticas públicas descentralizadas.

Quanto à gestão escolar, Oliveira e Vasques-Menezes (2018), ao realizarem levantamento das pesquisas da área no período entre 2005 e 2015, afirmam que ainda existem lacunas relacionadas aos assuntos que foquem nas competências, formação, identidade e qualidade do trabalho dos gestores escolares. As autoras apresentam como ponto positivo dos estudos na área, o predomínio das pesquisas que relacionam a gestão escolar com a necessidade de uma gestão democrática, especialmente nas pesquisas nacionais.

A respeito dos estudos voltados à implementação de políticas focados nas burocracias de médio escalão o trabalho de Cavalcante e Lotta (2015) apresenta uma contribuição importante ao analisar o campo teórico e empírico do tema através de estudos de setores governamentais e políticas públicas específicas. Já Oliveira e Abrucio (2018) investigaram especificamente os diretores de escolas como burocratas de médio escalão (como se pretende fazer também neste trabalho) e verificaram pontos importantes sobre esses agentes. Dentre estes destacamos os incentivos institucionais específicos e a própria lógica da política pública que devem ser melhor compreendidos. No caso específico da educação, a autonomia escolar do gestor é positiva quando há qualificação e condições materiais para isso. Os autores ressaltam que o estabelecimento de metas e regras não deve coibir a capacidade de inovação e discricionariedade dos gestores. Por fim, a pesquisa destaca a importância do aprofundamento de estudos sobre a burocracia de médio escalão, por considerá-la essencial nos resultados das políticas públicas e na interligação com o restante do sistema administrativo devido às suas funções e à identidade dos atores.

No que tange aos burocratas de nível de rua (também analisados na presente pesquisa), Cavalcante, Lotta e Pires (2018) ressaltam que os estudos têm apresentado variações entre estilos de implementação e resultados das políticas. Dessa forma, os debates do campo têm revelado aspectos individuais e dinâmicas coletivas que influenciam o exercício da discricionariedade de cada um desses atores e afetam os resultados das políticas. As pesquisas também abrem perspectivas de discussão sobre como as políticas podem investir em formação 
profissional para alterar valores, práticas e formas de fazer baseadas nas ações individuais. Os autores enfatizam que o campo das pesquisas de burocracia de nível de rua ainda é pequeno no Brasil, possuindo grande potencial para contribuições que trarão desenvolvimento na literatura, no desempenho e na implementação das políticas, na medida em que evidenciam processos cotidianos que podem afetar os resultados.

Quanto aos estudos que focam a discricionariedade dos burocratas de nível de rua, destacamos o trabalho de Oliveira (2017) que buscou investigar a implementação da política de correção de fluxo em uma escola municipal do Rio de Janeiro a partir da percepção dos agentes escolares, analisando de que forma elas influenciam sua discricionariedade. Os resultados mostram, dentre outros fatores, os limites e possibilidades do senso prático-moral que orienta as ações discricionárias. Por um lado, invenções e improvisações, pragmáticas realizadas pelos agentes escolares para lidar com as contingências do contexto de implementação e com a inadequação das próprias regras formais da política. Por outro, esse mesmo senso de pragmatismo permeado por juízos morais que percebem os alunos de forma binária e estereotipada. A autora ressalta a (re)atribuição de sentido em um cenário de intensa sobrecarga de trabalho e falta de recursos que faz com que escolhas éticas e morais tornem-se relevantes no trabalho ao nível de rua, diante de sua capacidade de influenciar a elegibilidade dos cidadãos no acesso ao serviço público.

Importante destacar que não foi encontrado nenhum trabalho que abordasse a temática da implementação de políticas públicas da educação especial relacionando-a com os burocratas de médio escalão e burocratas de nível de rua, dessa forma, buscamos contribuir com as discussões referentes às políticas educacionais voltadas às pessoas com deficiência, oferecendo um olhar distinto a respeito do seu processo de implementação, ao abordarmos a discussão com foco nos agentes implementadores.

Considerando os aspectos elencados, o objetivo principal desta pesquisa foi investigar a implementação da política de educação especial na perspectiva da educação inclusiva a partir da atuação dos agentes implementadores na rede municipal de ensino de Corumbá/MS. 
Os objetivos específicos consistiram em conhecer de que forma as políticas da educação inclusiva são implementadas e executadas na rede municipal de ensino de Corumbá; quais são as condições do atendimento dos alunos público alvo das políticas da educação especial nas escolas da rede municipal; investigar qual a atuação dos agentes implementadores no âmbito da secretaria municipal de educação (Núcleo de Inclusão Escolar e Diversidade e Centro Multiprofissional de Apoio ao Desenvolvimento Infanto-Juvenil - CMADIJ) e; averiguar a atuação dos agentes implementadores no contexto das unidades escolares.

Além desta apresentação, o presente trabalho está organizado da seguinte forma: o primeiro capítulo apresenta inicialmente, a discussão da perspectiva sociológica sobre a deficiência, pano de fundo que possibilita compreender de que maneira as pessoas com deficiência são vistas histórica e socialmente. Ainda nesse capítulo, será abordada a influência das organizações internacionais nas políticas da educação especial, considerando os períodos de 1960 a 1980, as mudanças advindas da Constituição de 1988, as políticas da educação especial na perspectiva da educação inclusiva instauradas na década de 1990 e nos anos 2000. Por fim, retomamos na discussão sobre a implementação das políticas educacionais a atuação dos burocratas de médio escalão e dos burocratas de nível de rua, cujas categorias serão utilizadas na análise dos dados coletados.

No capítulo dois apresentaremos o campo da pesquisa a partir de breve histórico da educação especial no município de Corumbá e o panorama da rede municipal de ensino a partir do dados do Censo Escolar 2016.

O terceiro capítulo apresenta a discussão dos resultados no âmbito da Secretaria Municipal de Educação, ressaltando os agentes que compõe o Núcleo de Inclusão Escolar e Diversidade e o Centro Multiprofissional de Apoio ao Desenvolvimento Infanto-Juvenil (CMADIJ). Retomamos a discussão a respeito das políticas educacionais voltadas às pessoas com deficiência buscando integrar as análises no nível micro (escolas) e macro (secretaria municipal de educação, seus órgãos e atores com burocratas de médio escalão).

O capítulo quatro aborda as discussões no âmbito das unidades escolares, apresentando os diretores, coordenadores (considerados burocratas de médio 
escalão e em algumas situações burocratas de nível de rua) e professores e suas relações com a secretaria de educação, alunos e famílias.

O quinto e último capítulo apresenta as considerações finais e as possibilidades e sugestões de pesquisas futuras considerando a temática das políticas da educação especial com foco nos agentes implementadores. 


\section{1 POLÍTICAS EDUCACIONAIS PARA PESSOAS COM DEFICIÊNCIA: história, perspectivas e implementação}

Inicialmente apresentamos as discussões acerca da perspectiva sociológica sobre a deficiência para situar o panorama conceitual sobre a maneira como a deficiência foi historicamente concebida na sociedade. Em seguida abordamos a influência dos organismos internacionais nas políticas educacionais, realçando sua importância para a criação de normativas que regem o campo das políticas educacionais voltadas às pessoas com deficiência. A partir daí, descrevemos as políticas da educação especial no Brasil do período de 1960 a 1980, os impactos trazidos pela Constituição de 1988, as políticas da educação especial nos anos de 1990 e a partir dos anos 2000. Ao final, falaremos sobre a implementação de políticas públicas com foco na discricionariedade dos agentes implementadores.

\section{1 \\ Discussões a partir da perspectiva sociológica sobre a deficiência}

A Educação Especial enfrenta em seu cerne o desafio de nomear o seu próprio público-alvo. A discussão a respeito do termo adequado para abordar a temática ainda hoje é um desafio do campo.

Como exemplos podemos citar alguns documentos oficiais que tratam as pessoas com deficiência com nomenclaturas diferenciadas, tais como a Portaria $n^{\circ}$ 1.793/94 que dispõe sobre a necessidade de complementar os currículos de formação de docentes e outros profissionais que interagem com portadores de necessidades especiais. Já o Decreto no 3.298/99 dispõe sobre a Política Nacional para a Integração da Pessoa Portadora de Deficiência. A partir dos anos 2000 os documentos oficiais referem-se às pessoas com deficiência (a exemplo do Decreto nº186/2008 que aprova o texto da Convenção sobre os Direitos das Pessoas com Deficiência $\left.{ }^{3}\right)$.

\footnotetext{
${ }^{3}$ Grifos nossos.
} 
Pessoa deficiente, pessoa portadora de deficiência, pessoa com necessidades especiais, pessoas especiais, pessoas com deficiência, são exemplos de nomes utilizados para tratar uma mesma população. Diversas são as nomenclaturas e os significados apresentados, sobretudo, em convenções internacionais e legislações que tratam do assunto. No entanto, nesse âmbito persistem questões que vão além da simples denominação de um determinado grupo de pessoas e envolvem aspectos sociológicos.

Sassaki (2003) ressalta que em todas as épocas e localidades "a pergunta que não quer calar-se têm sido esta, com alguma variação: 'Qual o termo correto portador de deficiência, pessoa portadora de deficiência ou portador de necessidades especiais'?” (p.12). O autor afirma que não há (ou haverá) um único termo correto, válido definitivamente em todos os tempos e espaços e isso se deve ao fato de que, em cada época são utilizados termos cujo significado é compatível com os valores vigentes em cada sociedade, enquanto esta evolui em seu relacionamento com as pessoas com qualquer tipo de deficiência.

A concepção de deficiência como uma variação do normal da espécie humana foi uma criação discursiva do século XVIII, e desde então ter deficiência é experimentar um corpo fora da norma (Diniz, 2007). O corpo com deficiência somente se delineia quando contrastado com uma representação de o que seria o corpo sem deficiência. Entretanto, Diniz (2007) enfatiza que, ao contrário do que se imagina, não há como descrever um corpo com deficiência como anormal. A anormalidade é um julgamento estético e, portanto, um valor moral sobre os estilos de vida. Há quem considere que um corpo cego é algo trágico, mas há também quem considere que essa é uma entre várias possibilidades para a existência humana (idem, p.8).

$\mathrm{O}$ período entre os séculos XIX e XX marca a ideia da deficiência associada a causas naturais, vinculada à formação orgânica dos indivíduos, sobretudo na Europa. No Brasil, essa perspectiva encontrou grande repercussão. Os médicos empenhavam-se em realizar pesquisas e atuar diretamente no campo educacional como professores, diretores de instituições educacionais e teóricos pedagógicos (Padilha, 2014). Jannuzzi (2017) afirma que a medicina influenciou a educação das pessoas com deficiência não só pela atuação direta dos médicos, 
como também pela dos diretores, professores e pelas repercussões de ensinamentos fundados na área da saúde. Por outro lado, os médicos também perceberam a importância da vertente pedagógica, enfatizando os aspectos ligados à segregação versus integração na prática social mais ampla, sendo os primeiros a teorizarem sobre o assunto.

Com o objetivo de contrapor o modelo médico surgem em meados do século XX, mais precisamente durante a década de 1970, as discussões acerca do modelo social de deficiência. A partir desses estudos, a deficiência passa a ser considerada um conceito complexo que reconhece os aspectos biológicos e fisiológicos, mas também denuncia a estrutura social que oprime a pessoa com deficiência, assim como outras formas de opressão, como o racismo por exemplo. Para Diniz (2007) os estudos sobre a deficiência descortinam uma das ideologias opressoras da vida social: a que segrega o corpo com deficiência.

Os estudos sobre a deficiência oferecem uma discussão que considera a deficiência como uma marca da identidade do sujeito, assim como estudos sobre raça, etnia, classe e gênero. Tais estudos apontam que a questão central da deficiência não deve estar focada na pessoa, mas na construção do conceito de normalidade. "O problema é a forma como a normalidade é construída para criar o 'problema' da pessoa com deficiência” (DAVIS, 2006 p.3, tradução nossa, grifos do autor). O conceito de deficiência, a partir desses estudos, baseia-se não no diagnóstico médico, mas nos aspectos históricos e sociológicos que envolvem essas pessoas.

Omote (2004) ressalta que essa análise sobre a imagem social das pessoas com deficiência precisa ser percebida como parte integrante de um processo social e resultado de relações interpessoais que envolvem as pessoas nesta condição (condição de deficiência). Assim, os julgamentos a respeito da deficiência precisam ser tratados como parte do fenômeno social.

Nessa perspectiva, os Estudos sobre a Deficiência (Disability Studies) têm engendrado algumas reflexões. Valle e Connor (2014) afirmam que a maneira como as deficiências são compreendidas na educação especial é restritiva e até mesmo errada, considerando a confluência dos campos da Medicina, da Ciência e da Psicologia. Sob essa ótica, as escolas seriam incapazes de conceituar alunos 
com deficiência de outra forma que não seja como pessoas que precisam de uma "cura" (grifos dos autores).

Lacerda (2006) afirma que os estudos sobre a deficiência operam uma distinção entre lesão física (impairment) e invalidação social (disability) e privilegia a segunda como objeto de estudos ao utilizar os saberes das ciências humanas para entender como a sociedade constrói mecanismos de classificação e hierarquização dos indivíduos que apresentam algum tipo de lesão ${ }^{4}$. Lacerda explica que os estudos sobre a deficiência devem ajudar a desvelar valores e explicitar a construção social da deficiência pela cultura hegemônica, utilizando o modelo social onde antes era empregado o modelo médico, que definia a deficiência como um problema a ser tratado e curado (grifos da autora).

Ao abordarmos a temática da deficiência nos deparamos com situações em que os próprios sujeitos são tratados de acordo com o diagnóstico que possuem, não sendo enfatizados os aspectos ligados às suas capacidades e potencialidades. De acordo com Connor e Valle (2014) esta percepção permeia as relações entre pessoas com deficiência e sem deficiência. Os autores destacam ainda, que as representações da deficiência são quase sempre "problemáticas por perpetuarem estereótipos, distorções e incompreensões, que, por sua vez, perpetuam a marginalização das pessoas com deficiência" (CONNOR e VALLE, 2014 p. 41). Os autores exemplificam como a deficiência pode ser compreendida como uma construção social:

[...] uma usuária de cadeira de rodas pode ter um impedimento que requer que ela se movimente pelo mundo de um modo que não seja caminhando; contudo, se a usuária de cadeira de rodas quer entrar em um edifício que é acessível apenas para pessoas que caminham, ela se torna deficiente pelo contexto. Dessa forma, a deficiência pode ser entendida como uma construção social (p. 62).

Os teóricos do modelo social da deficiência, sobretudo na literatura britânica, reconhecem a preferência pelas expressões que denotem identidade na deficiência, sendo mais comum o uso do termo "deficiente". Quanto ao uso do termo pessoa com deficiência, o modelo social considera que ele denota que a deficiência é propriedade do indivíduo e não da sociedade (Diniz, 2007).

\footnotetext{
${ }^{4}$ Lacerda (2006) utiliza o termo lesão por achar que ele seja mais acurado para descrever uma limitação física. A autora afirma que no Brasil, os autores (SASSAKI, 2004) que trabalham com o modelo social traduzem o termo impairment como incapacidade.
} 
Em contrapartida, na Convenção Internacional sobre o Direito das Pessoas com Deficiência, promulgada no Brasil no ano de 2008 o termo escolhido foi "pessoa com deficiência”. Os princípios para se chegar a essa denominação foram os seguintes: não esconder ou camuflar a deficiência; mostrar com dignidade sua realidade; valorizar as diferenças e necessidades decorrentes da deficiência, combater neologismos, garantir os direitos e eliminar as restrições de participação (ONU, 2006). A escolha do termo foi realizada pelas próprias pessoas com deficiência, que enfatizaram tal ato a partir da frase: "Nada sobre nós, sem nós". Por esse motivo, neste trabalho utilizaremos o termo pessoa com deficiência.

A ampliação do acesso em todos os aspectos da sociedade é fundamental para todos, uma vez que as pessoas com deficiência teriam oportunidades mais igualitárias de acesso e as pessoas sem deficiência conviveriam em maior quantidade com pessoas com deficiência, conhecendo e entendendo suas necessidades e a importância da construção de espaços que considerem todas as diferenças humanas. A baixa visibilidade das pessoas com deficiência significa que ela permanece segregada nos mais diversos aspectos da experiência social (Valle e Connor, 2014).

Valle e Connor (2014) exemplificam a situação da seguinte forma: "ao planejar uma simples ida a um restaurante, uma pessoa fisicamente apta não precisa pensar sobre transporte público com acessibilidade, portas de entrada, assentos à mesa e banheiros, pois o mundo é configurado para pessoas como ela" (p.39). Os aspectos mais simples do cotidiano são fundamentalmente pensados para pessoas sem deficiência, o que se reflete diretamente na limitação da participação social das pessoas com deficiência em diversos espaços.

Ébersold (2005) afirma que as pessoas com deficiência devem fazer parte de todos os âmbitos da sociedade e define esse movimento a partir do que denomina uma abordagem inclusiva ${ }^{5}$. Esta perspectiva propõe uma dinâmica readaptativa que enfatiza a potencialidade das pessoas com deficiência e não suas dificuldades e impossibilidades. O movimento é oposto à visão da deficiência centrada no indivíduo: parte-se da capacidade dos sujeitos para proporcionar sua

\footnotetext{
${ }^{5}$ L'aprocche inclusive (EBERSOLD, 2005 p.43).
} 
inserção social e não da tentativa de "adaptar" esses indivíduos aos padrões estabelecidos pela sociedade (grifo meu). A necessidade de adaptação não é vinculada ao indivíduo, mas sim à sociedade. A deficiência não é considerada uma desvantagem social, mas é associada a uma restrição de participação que encontra sua fonte na inacessibilidade imposta pela sociedade.

A maneira como isso pode se estabelecer em uma sociedade está intimamente ligada à garantia de direitos. Os direitos iguais permitem ao indivíduo (seja ele com deficiência ou não) a garantia de sua autoproteção, pois possibilitam que ele mesmo se defenda e lute para garantir sua participação em questões econômicas, sociais e políticas (Ébersold, 2005). Os direitos possibilitam a autonomia dos sujeitos.

A respeito das visões sobre as capacidades das pessoas com deficiência, destacamos o conceito de capacitismo (palavra originária do Ableísmo - Ableism, derivado do verbo em inglês able - ser capaz de) que consiste na crença de que pessoas fisicamente aptas são superiores às pessoas com deficiência. De uma maneira geral, parte-se da premissa de que pessoas com deficiência possuem um status de segunda classe, sendo consideradas inferiores por seus pares sem deficiência, gerando atitudes prejudiciais e comportamentos discriminatórios com base na deficiência, independente de sua origem (física, intelectual, sensorial...). Considera-se que a pessoa com deficiência necessita de constante auxílio, estando permanentemente em dívida com os outros (Marçal, 2013). Importante ressaltarmos que esse comportamento pode não ser intencional, mas baseado numa construção social da deficiência pautada no modelo médico/assistencialista.

Em relação ao conceito de capacitismo, vale ressaltar que são utilizados os mesmos pressupostos que conceituam o racismo e o sexismo, por exemplo. O capacitismo nada mais é que o comportamento de discriminação voltado às pessoas com deficiência (HARPUR, 2009). Assim como em outros grupos minoritários, pessoas com deficiência têm que conviver com mensagens contraditórias recebidas de muitas frentes. Valle e Connor (2014) afirmam que o capacitismo pode assumir diversas formas, incluindo a utilização de estereótipos muito difundidos em diversos locais comuns, como livros, televisão, língua e história. Na língua, podemos verificar o uso de expressões como: "você é cego?", 
“você é surdo?", "você é retardado?”, “isso é uma pergunta imbecil”, “um ponto cego" são expressões que relacionam a deficiência à incapacidade, à negatividade, inconveniência, anormalidade e inferioridade.

A difusão desse tipo de uso da língua é mais provável de ocorrer porque as pessoas não consideram as questões das deficiências como equivalentes às questões raciais, étnicas, de gênero e de orientação sexual. As deficiências ainda continuam sendo um depósito de imagens e associações ruins, um conceito que as pessoas continuam a desvalorizar e a menosprezar. Embora não pretendamos ser uma polícia da linguagem, não podemos evitar achar interessante (e problemático) o quanto aviltar pessoas com deficiência é aceito socialmente - ao ponto de as pessoas não reconhecerem que elas o fazem! (VALLE e CONNOR, 2014 p.45).

Para Campbell (2009), o capacitismo está incorporado profundamente e subliminarmente dentro da cultura (grifos nossos). É resultado do posicionamento hegemônico dos indivíduos considerados "normais" na sociedade que atribuem uma conotação negativa àqueles que não se enquadram nos padrões de normalidade estabelecidos socialmente.

Valle e Connor (2014) enfatizam que para mudar as práticas capacitistas é necessário primeiramente refletir sobre nossas próprias atitudes, pois vivemos em uma cultura em que o capacitismo parece certo e natural, o que nos impele a pensar e agir de forma capacitista, independente do nosso nível de conhecimento a respeito do tema.

A construção social da deficiência e a forma como ainda a percebemos apontam para um longo caminho em busca da desconstrução de estereótipos, sobretudo no âmbito escolar. $\mathrm{O}$ acesso e a permanência desses atores em espaços considerados comuns a todos são fundamentais para que eles conquistem seu protagonismo social. Para tanto é necessário que eles estejam presentes nos mesmos locais e desfrutem das oportunidades que são ofertadas às pessoas sem deficiência, considerando sempre as especificidades próprias da diversidade humana. Nesse sentido, a constituição e a ampliação de políticas públicas voltadas a esses agentes são primordiais.

O item seguinte apresenta a forma como as políticas da educação especial são construídas a partir da influência dos organismos internacionais para que possamos abordar, posteriormente, como essas políticas foram constituídas no contexto brasileiro. 


\section{2. \\ A influência das organizações internacionais nas políticas da educação especial}

Após a Segunda Grande Guerra os organismos internacionais ganham força a partir da necessidade de ampliar o horizonte de convivência entre pessoas de diferentes povos do mundo. Os documentos advindos desses organismos priorizam, dentre outras regulações, a universalização da educação. Nesse horizonte, a educação como um direito extensivo a todas as pessoas integra um contexto de reorganização mundial. Um dos documentos mais importantes nesse sentido é a Declaração Universal dos Direitos Humanos, proclamada em 10 de dezembro de 1948 pela Organização das Nações Unidas, que estabelece todo homem tem direito à instrução gratuita, pelo menos, nos graus elementar e fundamental, sendo a elementar obrigatória (ONU, 1948).

Os organismos internacionais têm desempenhado um papel fundamental na organização das políticas educacionais. Por meio deles, são estabelecidos objetivos que devem ser alcançados pelos países signatários nos mais diversos campos. Para falarmos brevemente a respeito da influência dos organismos internacionais no contexto da educação, faz-se necessário apresentarmos alguns conceitos importantes, no entanto, ressaltamos que o aprofundamento dessa discussão não é objetivo do presente trabalho.

Iniciaremos apresentando o conceito de globalização, sendo ela "o processo pelo qual determinada condição ou entidade local estende a sua influência a todo o globo e, ao fazê-lo, desenvolve a capacidade de designar como local outra condição social ou entidade rival” (SANTOS, 1997 p. 14).

A relação entre globalização e educação é marcada por diversos fatores. Dale (2004) apresenta duas abordagens distintas que apesar de suas diferenças, procuram explicar a influência da globalização na educação: a Cultura Educacional Mundial Comum - CEMC e a Agenda Global Estruturada para a Educação - AGEE. Segundo o autor, a CEMC (desenvolvida pelo professor John Meyer e seus colegas da Universidade de Stanford - Califórnia) possui como argumento central que as instituições dos estados-nação, e o próprio estado, devem ser vistos como essencialmente moldados a um nível supranacional por 
meio de uma ideologia do mundo dominante (Ocidente), e não como criações autônomas e únicas. Sob essa ótica, os estados possuem políticas moldadas por normas e cultura universais.

Já a AGEE (desenvolvida pelo próprio Roger Dale) considera a globalização como um "conjunto de dispositivos político-econômicos para a organização econômica global, conduzido pela necessidade de manter o sistema capitalista, mais do que qualquer outro conjunto de valores" (DALE, $2004 \mathrm{p}$. 436). A adesão aos princípios ocorre através da pressão econômica e da percepção do interesse nacional próprio (idem).

A CEMC procura demonstrar a existência e o significado de uma hipotética cultura mundial, ideias e valores de nível mundial, mesmo quando estes não são reconhecidos. Tal abordagem mostra a existência de um nível de recursos culturais partilhados que embasou a maior parte dos sistemas educativos. Já a AGEE busca mostrar como os estados interpretam e respondem a uma agenda comum imposta sobre os sistemas educativos. Tal reconhecimento deve ter em conta que a forma, substância e estatuto dos roteiros se alteram qualitativamente, sendo mais restritos no seu âmbito e muito mais sujeitos à imposição, não passando pela adoção voluntária (Dale, 2004).

Ambas as abordagens apresentadas por Dale nos ajudam a entender a complexidade da construção das políticas públicas, uma vez que elas correspondem a interesses globais e locais que influenciam na criação da agenda e, posteriormente, na implementação dessas políticas. Robertson e Dale (2011) afirmam que as mudanças em âmbito global afetam os sistemas educacionais nacionais, pois envolvem novos atores, novas maneiras de pensar a respeito da produção e distribuição do conhecimento e novos desafios com a finalidade de assegurar a distribuição de oportunidades para o acesso e mobilidade social.

Tais mudanças influenciam a proposição de políticas públicas, sobretudo no campo das políticas sociais. Souza (2006) afirma que a política pública, de uma maneira geral, e a política social, em particular, são campos multidisciplinares. O foco estaria na forma como sua natureza e seus processos são explicados. A autora define políticas públicas como o campo do conhecimento que busca "colocar o governo em ação" (SOUZA, 2006 p.69), analisando suas 
ações e, quando necessário, propondo mudanças. Lasswell (1992) define a política pública por meio dos seguintes questionamentos: quem ganha o quê, por quê e que diferença faz? O autor também destaca que a decisão tomada pelos governos geralmente contém determinações tomadas fora do governo.

Di Giovanni (2009) define políticas públicas como "uma forma contemporânea de exercício do poder nas sociedades democráticas, resultante de uma complexa interação entre o Estado e a sociedade". O autor enfatiza que esta interação, de modo amplo, inclui as relações sociais estabelecidas no campo da economia e define as situações sociais consideradas problemáticas, assim como os conteúdos, os meios, os sentidos e modalidades de intervenção estatal.

Quanto às políticas sociais, Faleiros (2000, p.44) afirma que "as políticas sociais conduzidas pelo Estado capitalista representam um resultado da relação e do complexo desenvolvimento das forças produtivas e das forças sociais. Elas são o resultado da luta de classes e ao mesmo tempo contribuem para a reprodução das classes sociais".

São influenciadas por diversos fatores, sendo alguns deles as forças sociais, as mudanças nas políticas internacionais e as conquistas dos trabalhadores. Esses fatores modificam a correlação de forças e as conjunturas para a transformação e implantação das políticas. Portanto, as políticas sociais consistem um campo que se define historicamente por essas correlações. É através das lutas que surgem as alternativas de política social, por meio do equilíbrio de compromissos entre as forças presentes e os interesses em jogo (FALEIROS, 2000 grifos do autor).

É nesse contexto complexo que as políticas educacionais se efetivam, principalmente na construção e organização dos sistemas escolares, conforme veremos a seguir.

\subsection{1.}

O período entre 1960 a 1980

Nos anos de 1950 e 1960, período que antecede a primeira Lei de Diretrizes e Bases da Educação Nacional, o Brasil vivia uma fase desenvolvimentista com forte apoio de capital externo num movimento de 
aceleração do processo de industrialização, influenciando o desenvolvimento de outros setores da sociedade, sobretudo a educação (Saviani, 2008).

Ao longo da década de 1950, Theodoro Schultz construiu nos Estados Unidos a noção de capital humano como "estoque de conhecimentos, habilidades, atitudes, valores e níveis de saúde que potenciam a força de trabalho das diferentes nações" (FRIGOTTO, 2011 p.4, grifo do autor). Esta teoria sustenta a ideia de que os países deveriam investir em educação para se desenvolver e que esse investimento traria um retorno igual ou maior que outros investimentos produtivos, configurando a chave para diminuir a desigualdade entre nações, grupos sociais e indivíduos.

Frigotto (2011) pontua que a Teoria do Capital Humano possui uma perspectiva integradora da educação escolar ao mundo do emprego e, simultaneamente, expressa uma estratégia para evitar a penetração do ideário socialista e o risco de sua expansão, particularmente nos países subdesenvolvidos ou em desenvolvimento no contexto da guerra fria. Com base na Teoria do Capital Humano foram traçados planos, diretrizes e estratégias educacionais, principalmente para os países dependentes, tal como o Brasil, construindo o ideário de que a ascensão e mobilidade social têm um caminho garantido via escolaridade, mediante empregos bem remunerados (ibidem). Jannuzzi (2004, p. 13) afirma que a Teoria do Capital Humano "é a expressão mais explícita de vincular a educação com o desenvolvimento econômico do país, tal como ele se manifestava". Através da educação o aluno seria formado para ocupar os postos de trabalho existentes.

No contexto brasileiro este ideário foi incorporado inicialmente na primeira Lei de Diretrizes e Bases da Educação (Lei $n^{\circ}$. 4.024/61). Conforme Aguiar (2010) essa lei formula a tese da educação como instrumento de desenvolvimento social. Assim, a Teoria do Capital Humano ganha força no Brasil a partir dos anos de 1960 devido à preocupação cada vez maior com o crescimento econômico e a distribuição de renda.

A Lei de Diretrizes e Bases $n^{\circ}$ 4.024/61 reconhece que a educação dos "excepcionais" deveria, no que fosse possível, enquadrar-se no sistema geral de educação a fim de integrá-los na comunidade (BRASIL, 1961, grifo nosso). No 
entanto, a lei não especificava o tipo de atendimento a ser realizado com os alunos com deficiência, tampouco o nível de responsabilidade do Estado para com a escolarização desses alunos (REBELO, 2016). Além disso, como enfatizava que a educação dessa população deveria acontecer dentro do possível no sistema geral de educação, oportunizando que as instituições privadas de caráter assistencial mantivessem o atendimento desses alunos, não responsabilizava o Estado pela ausência desses atendimentos. Kassar (2011a) afirma que a adesão do Brasil aos acordos internacionais no período pós-1948 pode ser considerada impulsionadora na proposição das matrículas de alunos com deficiência nos sistemas de ensino, além dos movimentos internos de luta pela educação de pessoas com deficiência e disseminação dos preceitos da Escola Nova ${ }^{6}$.

Ainda na década de 1960, mais precisamente entre os anos de 1964 e 1968, o Ministério da Educação (MEC) e a United States Agency for International Development (USAID) estabelecem convênios de assistência financeira e assessoria técnica. Os acordos MEC-USAID ${ }^{7}$ instauraram treinamentos de pessoal docente e técnico para implantar programas de reformas e linhas gerais da organização universitária brasileira. Dentre elas, destacamos: satisfação, com os produtos da Universidade, das reais necessidades da sociedade; criação de cursos básicos de estudos fundamentais gerais; implantação do tempo integral dos professores; ampliação e diversificação dos cursos profissionais.

Gaio (2008) afirma que a modernização no Brasil foi imposta como projeto de uma concepção de mundo classista, sendo o Estado o protagonista da condução desse processo. A educação seria a condição essencial para a modernização. Porém, o ensino se vinculava à tecnologia e à profissionalização, representando a formação do trabalhador técnico para as indústrias.

\footnotetext{
${ }^{6}$ Lemme (2005) afirma que a Escola Nova foi um movimento de renovação escolar baseada nos progressos da psicologia infantil que reivindicava uma maior liberdade para a criança, o respeito às características de sua personalidade nas várias fases de seu desenvolvimento, colocando o "interesse" como o motor principal da aprendizagem (grifos do autor).

${ }^{7}$ Os acordos atingiram todos os níveis do sistema de ensino brasileiro (primário, médio e superior), abrangendo os ramos acadêmico e profissional e toda a estrutura de funcionamento (reestruturação administrativa, planejamento, treinamento de pessoal docente e técnico), além do controle geral do ensino através do controle de publicação e distribuição de livros técnicos e didáticos (ROMANELLI, 1986).
} 
Com o objetivo de melhorar o sistema educacional, recomenda-se a universalização do ensino fundamental e a elevação dos padrões de ensino. Assim, estariam sendo criadas as condições objetivas para a aquisição, na escola, das capacidades e conhecimentos para desenvolver as novas competências exigidas pelo desenvolvimento econômico (LAPLANE, 2013).

Em 1971 foi promulgada a Lei Educacional 5.692/71. Esta legislação fixou diretrizes e bases para a educação de $1^{\circ}$ e $2^{\circ}$ graus e ampliou a obrigatoriedade do ensino de primeiro grau para a idade de 7 a 14 anos (obrigatório até então por quatro anos). A lei fundiu o ensino primário ao $1^{\circ}$ ciclo do ensino médio, instituindo um novo ensino de $1^{\circ}$ grau, obrigatório, com oito anos de duração. Os quatro últimos anos seriam profissionalizantes e seu currículo teria como finalidade a sondagem vocacional e iniciação para o trabalho. Além dessa unificação parcial do ensino pós-primário, a lei também tornou obrigatório o $2^{\circ}$ grau profissional. A ideia era de que todos os alunos obtivessem no $2^{\circ}$ grau uma habilitação como técnico ou auxiliar técnico ${ }^{8}$ (Cunha, 2000). A educação como um fator econômico, baseada nas relações de mercado atribui ao indivíduo a responsabilidade de buscar o conhecimento e, com isso, alcançar o êxito profissional, ao mesmo tempo em que culpabiliza àqueles que não possuem condições de obter sucesso profissional.

Quanto à Educação Especial, a Lei 5.692/71 afirma que os alunos que apresentassem deficiências físicas ou mentais, os que se encontrassem em atraso considerável quanto à idade regular de matrícula e os superdotados deveriam receber tratamento especial (BRASIL, 1971). Nesse período, ainda não estavam estabelecidas as condições, e tampouco os atendimentos realizados exigiam uma definição clara e unívoca do público da Educação Especial, pois a formulação incluía também nesta categoria alunos com atraso considerável quanto à idade regular de matrícula. Ao lado disso, a lei 5.692/71 mantinha as relações entre os setores público e privado ao enfatizar o princípio da intercomplementaridade dos estabelecimentos de ensino entre si ou com outras instituições sociais e, nesse

\footnotetext{
${ }^{8}$ Cunha (2000) também destaca que a profissionalização universal e compulsória no $2^{\circ}$ grau tinha a função de conter a demanda de candidatos para o ensino superior, de modo a encaminhar os alunos para um mercado de trabalho supostamente carente de profissionais habilitados.
} 
caso em particular da rede filantrópica privada de atendimento aos alunos com deficiências (REBELO, 2016).

Rebelo (2016) ressalta que os atendimentos em Educação Especial, naquele período (década de 1970), precisavam ser estabelecidos nas diferentes redes de ensino, devido à classificação e aos encaminhamentos dos alunos considerados "excepcionais" para as classes especiais, serviços de apoio pedagógico, salas de recursos, entre outros. Essa demanda foi ampliada pela expansão da educação obrigatória.

$\mathrm{Na}$ construção das políticas da educação especial é importante destacar a

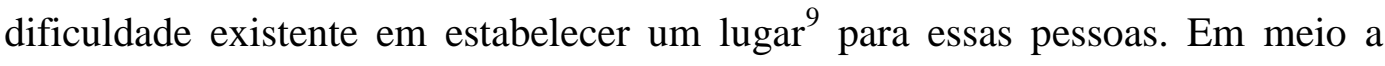
essas modificações, o discurso do modelo médico, que responsabiliza o indivíduo por sua própria aprendizagem, esteve presente, tirando da escola a responsabilidade de ensinar esses alunos, como nos aponta Mazzotta (2005, p.73) ao se referir aos anos de 1970 e início dos anos 1980: "Em tais diretrizes fica patenteado um posicionamento que atribui um sentido clínico elou terapêutico à educação especial, na medida em que o atendimento à educação assume caráter preventivo/corretivo. Não há aí uma característica de educação escolar propriamente dita".

Dessa forma, as ações são orientadas no sentido de possibilitar que as pessoas com deficiência se "adequem" aos ambientes voltados às pessoas sem deficiência. Um exemplo dessa situação pode ser visto na Portaria Interministerial $n^{\circ}$ 186/78, publicada pelos Ministérios da Educação e Cultura e Ministério da Previdência e Assistência Social que organiza o planejamento e implementação dos programas de atendimento às pessoas com deficiência.

Kassar e Rebelo (2011) destacam que esse documento estabelece uma "meta mínima" a ser atingida pelos alunos com deficiência, que acaba por ter uma finalidade em si mesma, pois estaria integrado socialmente o aluno capaz de atingir total ou parcialmente uma independência nas atividades de vida diária (hábitos de higiene, vestir-se, deslocar-se, alimentar-se, entre outros). O olhar voltado à concepção médica está presente na legislação. A partir dele, o objetivo

\footnotetext{
${ }^{9}$ Para verificar essas modificações de maneira mais detalhada, ver Quadro I no apêndice do presente trabalho.
} 
da educação especial seria reabilitar, corrigir e o aluno seria aceito caso conseguisse realizar as atividades do cotidiano ou pudesse "beneficiar-se dos recursos da educação especial" (p.5 grifos das autoras).

É a partir dessa concepção que as políticas educacionais para as pessoas com deficiência vão tomando forma, diante das nuances sócio-históricas e das conjunturas políticas do país. No próximo item mostraremos como isso se consolidou no Brasil a partir da Constituição Federal de 1988.

1.2.2.

A municipalização da educação a partir da Constituição Federal de 1988 e as políticas educacionais na década de 1990

A partir da década de 1980, a descentralização constitui-se como um princípio norteador de reformas do setor público, expressando também um importante ingrediente das reformas advogadas por governos neoliberais em escala global, tendo como difusores as instituições multilaterais como o Banco Mundial e o Fundo Monetário Internacional (FMI) (MELO, 1996).

A Constituição de 1988 preconiza em seu artigo 211, que os entes federados organizarão os sistemas de ensino estabelecendo um regime de colaboração com uma significativa transferência de funções, decisões e recursos do plano federal para estados e municípios (no caso da educação, esse aspecto consta do artigo 60 do Ato das Disposições Constitucionais Transitórias - ADCT). A Constituição de 1988 desenha assim um novo quadro de responsabilidades educacionais que alterou o arranjo federativo do Brasil quanto às relações entre o Estado e o setor privado lucrativo e não lucrativo na oferta e distribuição de educação escolar (BONAMINO, 2003).

O processo de municipalização é parte do projeto de reforma do Estado que busca racionalizar recursos, diminuindo seu papel no que se refere às políticas sociais (PERONI, 2003). A reforma do Estado é preconizada por meio da premissa de que é preciso reorganizar as estruturas da administração pública levando em conta a qualidade e produtividade do serviço público (BRASIL, 1995). Tal afirmação nos mostra que a redefinição do papel do Estado está 
baseada na descentralização, publicização ${ }^{10}$ e terceirização, aspectos ligados a um modelo de administração gerencial.

Foi durante os anos de 1990 que o Brasil implantou um grande número de políticas sócio-educacionais, dirigidas principalmente às camadas populares. Platt (2004) afirma que essas medidas tinham por objetivo acomodar as camadas populares diante dos "novos tempos" de reajuste estrutural da produção capitalista. Segundo ela, os anos de 1990 foram a chave para a arrancada da reestruturação produtiva e transformações qualitativas para alcançar competitividade internacional, e nesse sentido, o setor educacional foi estratégico para conter os focos de insatisfação do novo modelo social (PLATT, 2004). Por outro lado, foi nesse período que ocorreu uma acelerada ampliação da cobertura da educação básica e da dimensão das redes de ensino estaduais e municipais propiciando o aumento expressivo da taxa de atendimento do sistema educacional (PAES DE CARVALHO; BONAMINO; KAPPEL, 2011).

Nesse contexto, temos duas grandes convenções organizadas pelos organismos internacionais, sendo elas: a Conferência Mundial sobre Educação para Todos realizada em Jomtien, Tailândia em 1990 e; a Declaração de Nova Delhi em 1993. Ambas foram patrocinadas por órgãos como o Banco Mundial, UNESCO (Organização das Nações Unidas para a Educação, a Ciência e a Cultura), UNICEF (Fundo das Nações Unidas para a Infância) e PNUD (Programa das Nações Unidas para o Desenvolvimento). As convenções estabeleceram, dentre outros aspectos, a promoção de valores humanos universais, respeito à diversidade e a qualidade dos recursos humanos e satisfação das necessidades básicas de aprendizagem.

No Brasil, a Declaração de Jomtien lançou as bases para a elaboração do plano Decenal de Educação para Todos, no ano de 1993 durante o governo Itamar Franco, marcando a influência dos organismos internacionais na legislação brasileira. Ainda durante a década de 1990 diversos outros documentos voltados à educação foram publicados pelos organismos internacionais, a exemplo:

\footnotetext{
${ }^{10}$ A publicização consiste na transferência do setor estatal para o público não-estatal através da atuação de "organizações sociais", que são entidades de direito privado que, por iniciativa do Poder Executivo, obtém autorização para celebrar contrato de gestão com esse poder e assim ter direito à dotação orçamentária (BRASIL, 1995 grifos dos autores).
} 
Transformación productiva com equidade e Educación y conocimiento, ambas organizadas pela CEPAL (Comissão Econômica para a América Latina e Caribe). Os documentos tinham por objetivo a ampla reforma dos sistemas educacionais para a capacitação profissional e o aproveitamento da produção científicotecnológica (FRIGOTTO; CIAVATTA, 2003), além da universalização do acesso escolar, financiamento e repasse de recursos, descentralização da gestão, estabelecimento de Parâmetros Curriculares Nacionais, expansão do ensino à distância, políticas do livro didático, entre outras (LIBÂNEO, 2012).

Libâneo (2012) afirma que na Declaração de Jomtien são definidas estratégias aceitáveis na direção de uma educação para todos, no entanto, esses conceitos acabam sendo encolhidos para adequar-se à visão economicista do Banco Mundial, o patrocinador das conferências mundiais. Nóvoa (2009) afirma que um dos grandes perigos dos tempos atuais é uma escola "a duas velocidades", concebida essencialmente como um centro de acolhimento social, para os pobres, com uma forte retórica da cidadania e participação e uma escola centrada na aprendizagem e nas tecnologias, destinada aos filhos dos ricos. Assim, a visão ampliada de educação se converteria numa visão encolhida da educação, sendo a última adotada pelos países em vias de desenvolvimento.

No campo da Educação Especial, o marco mais importante foi a Declaração de Salamanca, organizada pela UNESCO na Conferência Mundial sobre Necessidades Educacionais Especiais, que ocorreu na cidade de Salamanca na Espanha em 1994. A Conferência visou informar e guiar ações governamentais, de organizações internacionais ou agencias nacionais de auxílio, organizações não-governamentais e outras instituições quanto à implementação de políticas e práticas em Educação Especial. A Declaração de Salamanca prioriza em seus preceitos, a inserção de todas as crianças no sistema regular de ensino e ressalta que um espaço adequado aos alunos com deficiência é um espaço adequado a todas as crianças. Enfatiza também que crianças com necessidades educacionais especiais ${ }^{11}$ devem receber qualquer suporte extra requerido para

\footnotetext{
${ }^{11}$ A declaração conceitua o termo necessidades educacionais especiais da seguinte forma: todas aquelas crianças ou jovens cujas necessidades educacionais especiais se originam em função de deficiências ou dificuldade de aprendizagem.
} 
assegurar uma educação efetiva e que os encaminhamentos às escolas ou classes especiais devem constituir exceções, sendo realizados somente em casos onde fique demonstrado que a educação na classe regular seja incapaz de atender às necessidades educacionais ou sociais da criança (UNESCO, 1994).

Um ponto importante da declaração é o item voltado aos recursos, priorizando o fortalecimento de escolas inclusivas ao afirmar que tais escolas são mais bem-sucedidas em apoio da comunidade e em achar modos imaginativos e inovadores de uso dos limitados recursos que sejam disponíveis (grifo nosso). A esse respeito Kassar (2011b, p. 71) afirma que a declaração "enuncia que diante do alto custo em manter instituições especializadas as escolas comuns devem acolher todas as crianças independente de suas condições físicas, intelectuais, sociais, emocionais, linguísticas ou outros".

É interessante observar que mesmo que a Declaração de Salamanca preconize importantes avanços na Educação Especial delega-se à escola a responsabilidade de gerir os recursos - via de regra escassos - utilizando-se de modo imaginativo e inovador para conseguir alcançar seus objetivos. Laplane (2013) ressalta que as declarações que apregoam uma educação inclusiva, universal, não consideram questões políticas, que envolvem relações de poder, combate aos privilégios e à desigualdade econômica e social, mas sim, dependem 'da convicção, do compromisso e da boa vontade de todos os indivíduos que integram a sociedade' (BRASIL, 1994 p.23). Para a autora, o discurso em defesa da inclusão constituiu-se como um importante elemento no campo da educação, porém acaba sendo mistificado pela ausência de contextualização das realidades locais. Questões históricas, políticas e sociais são ignoradas e a responsabilidade de incluir acaba recaindo sobre os sujeitos (pessoas com deficiência, familiares, professores, entre outros).

A afirmação de que a inclusão representa a única e melhor solução para alunos, professores, pais e sociedade, põe em evidência um mecanismo discursivo que opera para assegurar a eficácia do discurso. Sua fraqueza, entretanto, reside no fato de que em certo momento o discurso contradiz a realidade educacional brasileira, caracterizada por classes superlotadas, instalações físicas insuficientes, quadros docentes cuja formação deixa a desejar. Essas condições de existência do nosso sistema educacional levam a questionar a própria ideia de inclusão como política que, simplesmente, insira alunos nos contextos escolares existentes. [...] esse discurso apaga o quadro de tensões e contradições no qual a política inclusiva se insere (LAPLANE, 2013 p. 18). 
Jannuzzi (2004) afirma que a Declaração de Salamanca implica uma reestruturação do sistema comum de ensino, porém enfatiza que, durante a década de 1990 houve uma diminuição da atuação do Estado, desprestigiando-o em detrimento do setor privado e das organizações não-governamentais que, em muitos casos, suprem a obrigatoriedade estatal em relação à educação e à saúde. A ampliação da educação inclusiva acompanhou (ainda que de modo mais lento) o processo de universalização do ensino fundamental (SILVA; CAVALCANTE, 2016).

No bojo dessas transformações educacionais o Brasil promulga em 1996 uma nova Lei de Diretrizes e Bases da Educação Nacional (Lei 9.394/96). A LDB/96 reafirma o dever do Estado para a educação através da garantia de padrões mínimos de qualidade de ensino, definidos como a variedade e quantidade mínimas, por aluno, de insumos indispensáveis para o desenvolvimento do processo de ensino-aprendizagem (GIL ET AL, 2010).

Outra medida importante estabelecida durante o governo de Fernando Henrique Cardoso com o propósito de alcançar um objetivo nacional para reduzir as assimetrias intra-estaduais de gasto no ensino fundamental e promover a valorização salarial dos professores foi a criação em 1996, pouco depois da promulgação da LDB/96, do Fundef ${ }^{12}$ (Fundo de Manutenção e Desenvolvimento do Ensino Fundamental e de Valorização do Magistério).

$\mathrm{O}$ acelerado processo de municipalização pode ser explicado em grande parte pelo interesse dos municípios em aumentar suas receitas, que, a partir do Fundef, era a única estratégia possível para preservar as receitas municipais passou a ser aumentar a oferta de matrículas municipais na rede de ensino fundamental. A municipalização é o resultado da estrutura de incentivos da nova legislação sobre a decisão dos governos locais (ARRETCHE, 2002). Esse

\footnotetext{
${ }^{12}$ Instituído pela Emenda Constitucional n.14 o Fundef implicou uma minirreforma tributária de âmbito estadual, uma vez que, a cada ano, $15 \%$ das receitas de estados e municípios seriam automaticamente retidas e contabilizadas em fundo estadual. Essas receitas foram redistribuídas, no interior de cada estado, entre governos estaduais e municipais conforme o número de matrículas oferecidas anualmente (Arretche, 2006). Essas regras valeram por 10 anos e possuíram um caráter redistributivo do ponto de vista regional, considerando a existência de um teto mínimo a ser despendido com cada aluno e, caso os recursos vinculados não atingissem o mínimo exigido, o governo federal suplementaria a diferença.
} 
movimento "municipalizador" foi acompanhado de ações que resultaram em novas atribuições educacionais aos gestores das cidades, como: merenda, transporte escolar, reformas e manutenções de prédios e equipamentos, fornecimento para escolas estaduais e privadas, dentre outras funções. Esse processo tem levado as administrações municipais a criar novas estruturas, ou ampliar as existentes para fazer frente às suas crescentes funções, modificando e tornando mais complexos os arranjos institucionais da máquina pública (GIL ET AL., 2010, grifo dos autores).

No nível político-institucional, entre as inovações introduzidas na década de 1990 no campo da educação, temos a adoção de medidas que buscam consolidar a tendência à descentralização administrativa, financeira e pedagógica (BONAMINO, 2003). No entanto, apesar disso, observamos ainda uma centralização do governo federal em relação às políticas da educação no que diz respeito às suas diretrizes (a exemplo: parâmetros curriculares e avaliação das instituições). Nesse contexto de descentralização/centralização, as atribuições do diretor escolar se ampliaram, pois ele torna-se um dos principais responsáveis pela implementação das políticas educacionais, e é chamado a se responsabilizar pelos resultados apresentados por sua unidade escolar.

Em síntese, pode-se dizer que a LDB acaba por colocar a política educacional ante uma nova forma de gestão estatal, na qual, através da descentralização, se flexibiliza a base da oferta escolar, enquanto a União se reserva o poder de avaliar centralizadamente os resultados educacionais (BONAMINO, 2003 p. 265-266).

A partir desses fatores, a investigação sobre as condições que os agentes implementadores (nesse caso, especificamente os diretores escolares) possuem é de grande importância, uma vez que eles, considerados agentes híbridos atuam tanto nas articulações realizadas no contexto das secretarias, quanto na implementação da política, ao interagir com os atores que se encontram na ponta do processo (professores, alunos e familiares). No que tange às políticas da educação especial, alertamos ainda para a interveniência das instituições privadas de caráter assistencial, que através de um processo de publicização mantém elo com o poder público. Nesse sentido, Dale e Gandin (2014) afirmam que o fortalecimento do terceiro setor constitui-se como uma resposta para o enfraquecimento da economia como base da prosperidade nacional, além de 
possuir forte relação com a nova gestão pública, que tende à descentralização do Estado.

Apresentados os aspectos referentes aos anos de 1990, no próximo item abordamos as políticas da educação especial implementadas a partir dos anos 2000.

\subsection{3.}

As políticas da educação especial na perspectiva da educação inclusiva a partir dos anos 2000

A educação no Brasil na perspectiva de uma educação inclusiva se origina a partir da adoção de uma política educacional voltada à universalização do Ensino Fundamental, mesmo período em que as agências internacionais difundem as mudanças referentes às matrículas de alunos com deficiência na escola comum (Kassar, 2011b), conforme já apresentado no item anterior. No entanto, os documentos que visam a garantia de uma educação voltada às pessoas com deficiência na rede regular mantêm o viés da publicização.

No ano de 2001, o Conselho Nacional de Educação (CNE) promulga a resolução que institui as Diretrizes Nacionais para a Educação Especial na Educação Básica. Este documento regulamenta os artigos presentes na LDB 9.394/96 (que instituiu a Educação Especial como modalidade educacional). A resolução $\mathrm{CNE} / \mathrm{CEB}$ 2/2001 propõe também que a educação dos alunos com deficiência ocorra na escola regular. O termo "preferencialmente" foi suprimido e em seu lugar foi utilizado o termo "em caráter extraordinário", como podemos verificar no artigo 10 da resolução:

Os alunos que apresentem necessidades educacionais especiais e requeiram atenção individualizada nas atividades da vida autônoma e social, recursos, ajudas e apoios intensos e contínuos, bem como adaptações curriculares tão significativas que a escola comum não consiga prover, podem ser atendidos, em caráter extraordinário, em escolas especiais, públicas ou privadas, atendimento esse complementado, sempre que necessário e de maneira articulada, por serviços das áreas de Trabalho e Assistência Social (BRASIL, 2001 p. 3).

No entanto, apesar da orientação quanto à matrícula desses alunos no sistema regular de ensino, Garcia e Michels (2011) apontam que a mudança no termo mantém a histórica lógica dual integrado/segregado, modificando sua 
intensidade. A Resolução no 02 ganhou importância ao normatizar no Brasil as premissas inclusivas presentes no debate internacional e, ao mesmo tempo, expressou o modo pelo qual a política brasileira incorporou as ideias que se firmaram hegemônicas no campo da Educação Especial. No entanto, a resolução manteve os atendimentos nas classes e escolas especiais.

Quanto ao público-alvo, a Resolução utilizou a terminologia "alunos com necessidades especiais", definidos como aqueles que apresentam dificuldades de aprendizagem, com ou sem correlações orgânicas. A utilização desta definição, a exemplo das indicações encontradas na Declaração de Salamanca abriu o foco de atenção para uma diversidade de sujeitos muito grande e fora das características da Educação Especial (Garcia; Michels, 2011).

Importante ressaltar o uso do termo "inclusão" está presente na legislação educacional desde o início dos anos 2000, porém, já estava presente também na LDB 9.394/96 Michels e Garcia (2014) apontam que o termo “educação inclusiva" foi apreendido na política educacional brasileira como uma expressão relacionada quase que exclusivamente à educação especial, mesmo que os discursos políticos presentes na documentação internacional não tragam essa interpretação. Bueno (2008) analisa as políticas de inclusão escolar como uma prerrogativa da educação especial. $\mathrm{O}$ autor utilizou documentos nacionais e internacionais, bem como produções acadêmicas disponíveis no Banco de Teses da CAPES (entre os anos de 1997 e 2003) com o objetivo de contribuir para o aprofundamento das reflexões críticas a respeito da "inclusão escolar" e da "educação inclusiva".

Também em 2001 foi promulgada a Lei $\mathrm{n}^{\circ} 10$. 172/2001 que instituiu o Plano Nacional de Educação (2001 - 2011). O plano definiu diagnósticos, diretrizes, objetivos e metas relacionadas a educação básica, educação superior e modalidades de ensino, Formação dos Professores e Valorização do Magistério, Financiamento e Gestão, além do Acompanhamento e Avaliação do Plano, propugnando a efetivação de uma gestão descentralizada pela via do regime de colaboração entre os entes federativos (Souza, 2014). Dourado (2010) afirma que, apesar de contar com metas de amplo alcance, o plano foi marcado pela ausência de mecanismos concretos de financiamento. 
O PNE/2001 contempla em seus objetivos e metas a educação especial, no entanto, dos 28 itens dedicados ao tema, apenas um (n.25) depende da atuação da União. Do total, quatorze "exigem" a associação da União, porém, esta não se responsabiliza diretamente por nenhuma delas. Os demais objetivos e metas ficam partilhados entre União, estados e municípios ou Organizações da Sociedade Civil, caracterizando a responsabilidade dos municípios em assumir a efetivação das políticas públicas da educação especial (CORRÊA, 2005).

Ainda em 2001, o Ministério da Educação lança as Diretrizes Nacionais para a Educação Especial na Educação Básica. Essas diretrizes regulamentam a organização e a função da educação especial nos sistemas de ensino da educação básica e a manutenção do repasse de verbas e recursos humanos para instituições privadas através de parcerias (PLETSCH, 2014).

Durante o primeiro governo de Lula, o Ministério da Educação passou por algumas reestruturações no início de 2003 com a criação de novas secretarias, sendo duas delas voltadas à questão da inclusão: Secretaria Extraordinária de Erradicação do Analfabetismo (SEEA) e Secretaria de Inclusão Educacional (SECRIE). A inclusão social constitui um dos quatro eixos estratégicos da política educacional, sendo divulgados através dos slogans "Educação para Todos" e “Todos juntos para democratizar a educação" (MOEHLECKE, 2009). A ênfase nas questões voltadas à inclusão são reflexos dos documentos advindos dos organismos internacionais que, no final dos anos de 1990 e início dos anos 2000 reforçaram a importância de países como o Brasil, promoverem legislações que garantissem a participação social de grupos minoritários, como o de pessoas com deficiência.

Durante os dois mandatos do presidente Lula os Planos Plurianuais ("Plano Brasil de Todos: participação e inclusão" 2003-2006 e "Desenvolvimento com inclusão social e educação de qualidade" 2007-2010), mantêm a diretriz do governo anterior. Os planos enfatizavam a importância da inclusão social associada à desconcentração e redistribuição de renda, com crescimento de emprego e educação como prioridade articulada à atenção à diversidade e à inclusão social, respectivamente. 
Em 2003 é lançado o Programa Educação Inclusiva: direito à diversidade, promovido pela então Secretaria de Educação Especial (SEESP) do Ministério da Educação (MEC). O programa tem como diretriz principal: “disseminar a política de educação inclusiva nos municípios brasileiros e apoiar a formação de gestores e educadores para efetivar a transformação dos sistemas educacionais em sistemas educacionais inclusivos" (BRASIL, 2006 p. 1).

O programa foi organizado da seguinte forma: foram escolhidos 106 municípios-polo que atuaram, inicialmente, como multiplicadores para município da área de abrangência. Desde o início da formação do programa, Corumbá foi escolhida como município-polo $^{13}$. No ano de 2011/2012 foram atingidos 166 municípios-polo, atingindo 100\% dos municípios brasileiros (BRASIL, 2013). Para escolha dos municípios-polo o governo federal realizou um levantamento do número de municípios e localização, conforme as cinco regiões do país. Após essa etapa os municípios foram escolhidos por meio dos seguintes critérios: localidade geográfica, densidade demográfica, infraestrutura urbana e acessibilidade (BRASIL, 2005).

Oliveira (2012) afirma que os primeiros documentos desse programa foram divulgados por meio da série Educação Inclusiva, que contou com quatro livros, sendo eles: A Fundamentação Filosófica; O Município; A Escola e; A Família. Os livros foram distribuídos gratuitamente para os sistemas educacionais municipais. Quanto à formação os municípios-polo, em parceria com o Ministério da Educação, ofereceram seminários (os Seminários da Educação Inclusiva: Direito à Diversidade) com duração de 40 horas (KASSAR, MELETTI, 2012).

Em 2007, já no segundo mandato do presidente Lula, foi lançado o Plano de Desenvolvimento da Educação $\left(\mathrm{PDE}^{14}\right)$, juntamente com o Decreto 6.094 que

\footnotetext{
${ }^{13}$ Sobre o funcionamento do programa em Corumbá, falaremos mais adiante.

${ }^{14}$ Trata-se, com efeito, de ações que cobrem todas as áreas de atuação do MEC, abrangendo os níveis e modalidades de ensino, além de medidas de apoio e de infraestrutura. As 30 ações apresentadas como integrantes do PDE aparecem no site do MEC de forma individualizada, encontrando-se justapostas, sem nenhum critério de agrupamento. Contudo, de modo geral, as ações podem ser distribuídas da seguinte maneira: No que se refere aos níveis escolares, a educação básica está contemplada com 17 ações, sendo 12 em caráter global e cinco específicas aos níveis de ensino. Entre as ações que incidem globalmente sobre a educação básica situam-se o "FUNDEB", o "Plano de Metas do PDEIDEB", duas ações dirigidas à questão docente ("Piso do Magistério" e "Formação"), complementadas pelos programas de apoio "Transporte Escolar",
} 
dispõe o "Plano de Metas Compromisso Todos pela Educação". O PDE abriga praticamente todos os programas em desenvolvimento pelo MEC, cobrindo todas as suas áreas de atuação e abrangendo todos os níveis e modalidades de ensino, além de medidas de apoio e infraestrutura (Saviani, 2008). Na educação especial foram lançados os seguintes programas, que compunham o PDE: Escola acessível, Benefício de Prestação Continuada na Escola ${ }^{15}$ e o Programa de Implantação das Salas de Recursos Multifuncionais. Souza (2013) enfatiza que a incorporação de programas voltados às pessoas com deficiência por parte do governo brasileiro representou o reconhecimento de que a organização escolar e as práticas pedagógicas existentes eram marcadas historicamente por uma "cultura escolar excludente, existindo, portanto, uma dívida social a ser resgatada" (BRASIL, 2007).

Em 2007 foi aprovada a Lei 11.494/2007 que regulamenta o Fundo de Manutenção e Desenvolvimento da Educação Básica e de Valorização dos Profissionais da Educação (FUNDEB) que, substituindo o FUNDEF, ampliou o número de níveis de ensino cobertos pelo então FUNDEF, que atendia apenas o ensino fundamental. A participação dos estados e municípios na composição do fundo foi elevada de 15 para $20 \%$, do montante de $25 \%$ de arrecadação de impostos obrigatoriamente destinados para a manutenção e desenvolvimento do ensino, assegurando-se a complementação da União (SAVIANI, 2007).

Padilha (2015) enfatiza o reforço financeiro garantido pelo FUNDEB no PDE e a manutenção do Programa Dinheiro Direto na Escola (PDDE) ${ }^{16}$ durante o segundo mandato do governo Lula. Segundo a autora, tal inclusão garantiu a implantação das Salas de Recursos Multifuncionais destinadas à oferta de Atendimento Educacional Especializado (AEE) nas escolas comuns.

\footnotetext{
"Luz para Todos", "Saúde nas Escolas", "Guias de tecnologias", "Censo pela Internet", "Mais educação", "Coleção Educadores” e "Inclusão Digital” (SAVIANI, 2007 p. 1.233).

15 Acompanhamento e monitoramento do acesso e permanência na escola dos beneficiários do Benefício de Prestação Continuada (BPC)

${ }^{16}$ Criado em 1995, o Programa Dinheiro Direto na Escola (PDDE) tem por finalidade prestar assistência financeira, em caráter suplementar, às escolas públicas da educação básica das redes estaduais, municipais e do Distrito Federal e às escolas privadas de educação especial mantidas por entidades sem fins lucrativos, registradas no Conselho Nacional de Assistência Social (CNAS) como beneficentes de assistência social, ou outras similares de atendimento direto e gratuito ao público (BRASIL, 2017).
} 
Quanto ao aspecto financeiro, Saviani (2007) argumenta que é forçoso reconhecer que o FUNDEB representa considerável avanço em relação ao seu antecessor (FUNDEF), pois promove a ampliação do raio de abrangência de toda a educação básica, não apenas no que se refere aos níveis, mas também às modalidades de ensino. Assim, o FUNDEB não representa a resolução do problema do financiamento da educação, mas sim um ganho de gestão. Os recursos alocados, se efetivamente aplicados e corretamente geridos, podem melhorar o financiamento da educação, mas não terão força para alterar o status quo vigente. Ou seja, uma boa gestão do fundo permitirá atender maior quantidade de alunos, porém em condições não muito menos precárias que as anteriores, com professores em regime de hora-aula, obrigados a ministrar grande número de aulas semanais para compensar os baixos salários, classes numerosas, dentre outros fatores estruturais (idem).

Em 2008 o governo federal publicou a Política Nacional de Educação Especial na Perspectiva da Educação Inclusiva ${ }^{17}$. Complementando a Política Nacional de Educação Especial na Perspectiva da Educação Inclusiva, temos ainda em 2008, o Decreto $\mathrm{n}^{\circ}$ 6.571/2008 que dispõe sobre o Atendimento Educacional Especializado (AEE). Realizado, prioritariamente, nas salas de recursos multifuncionais, o AEE é um atendimento que não substitui as classes regulares e pode ser oferecido tanto por instituições públicas, quanto por instituições comunitárias, confessionais ou filantrópicas sem fins lucrativos conveniadas com a Secretaria de Educação ou órgãos equivalentes (BRASIL, 2009). Ressalta-se mais uma vez a permanência de ações que sobrepõem o setor público e o setor privado, por meio da oferta de atendimento e financiamento de instituições privadas sem fins lucrativos.

O Decreto 6.571/2008 em seu artigo $9^{\circ}$ mantém, "para efeito da distribuição dos recursos do FUNDEB, o cômputo das matrículas dos alunos da

${ }^{17} \mathrm{O}$ objetivo da referida política consistia em garantir o acesso, a participação e a aprendizagem dos alunos com deficiência, transtornos globais do desenvolvimento e com altas habilidades/superdotação nas escolas regulares. O documento apresenta diretrizes voltadas às escolas na execução dos atendimentos voltados à educação especial em relação ao Atendimento Educacional Especializado (AEE), acesso à educação infantil, educação de jovens e adultos, educação profissional, educação superior, ingresso de estudantes surdos, avaliação pedagógica dos alunos com deficiência, além de orientar os sistemas de ensino quanto à organização do espaço, recursos pedagógicos, comunicação, valorização das diferenças de forma a atender as necessidades educacionais de todos os estudantes (BRASIL, 2008). 
educação regular da rede pública que recebem atendimento educacional especializado, sem prejuízo do cômputo dessas matrículas na educação básica regular" (BRASIL, 2008a). Como cada matrícula corresponde a um "custo-aluno" no FUNDEB, esses recursos extras, referentes à dupla matrícula deveria se destinar à execução desse atendimento e à manutenção das salas de recursos multifuncionais nas escolas. A Resolução do Conselho Nacional de Educação/Câmara de Educação Básica CNE/CEB 04/2009, regulamenta que cada matrícula de aluno com deficiência deva ser registrada duplamente, regulamentando o Decreto 6.571. Dessa forma, a resolução estabelece que o financiamento da matrícula no AEE é condicionado à matrícula do aluno no ensino regular da rede pública, conforme registro no Censo Escolar do ano anterior, contemplando:

a) Matrícula em classe comum e em sala de recursos multifuncionais da mesma escola pública;

b) Matricula em classe comum e em sala de recursos multifuncionais de outra escola pública;

c) Matricula em classe comum e em centro de Atendimento Educacional Especializado de instituição de Educação Especial pública;

d) Matricula em classe comum e em centro de Atendimento Educacional Especializado de instituições de Educação Especial comunitárias, confessionais ou filantrópicas sem fins lucrativos (BRASIL, 2009 p.2).

Rebelo (2016) afirma que a princípio, a Lei 11.494/2007 destinaria recursos financeiros para a dupla matricula dos alunos com deficiência matriculados no Atendimento Educacional Especializado (AEE) apenas para as escolas regulares/comuns. Porém, a lei foi alterada (pelo Decreto $n^{\circ}$ 6.253/2007) a partir da reivindicação das instituições especializadas privado-filantrópicas para que estas também pudessem ofertar o AEE e receber os recursos financeiros vinculados à matrícula dupla ${ }^{18}$.

Conforme Rebelo e Kassar (2017), nos últimos dez anos, além de contabilizar a matrícula dupla, as escolas que se enquadram nessa proposta podem contar também com o financiamento do Fundo Nacional de Desenvolvimento da

\footnotetext{
18 "Barbosa [deputado Eduardo Barbosa (PSDB - MG)] cobra inclusão de alunos especiais no Fundeb", 27 de janeiro de 2006. Disponível em http://www.psdb.org.br/acompanhe/noticias/barbosa-cobra-inclusao-de-alunos-especiais-nofundeb/ Acesso em 30 de janeiro de 2019 (apud Rebelo, 2015).
} 
Educação (FNDE) ${ }^{19}$. Pletsch (2013) ressalta que as indicações desses documentos têm sido amplamente difundidas e orientam os sistemas de ensino a se transformarem em "sistemas educacionais inclusivos" indo ao encontro dos princípios da Convenção Internacional sobre os Direitos das Pessoas com Deficiência da Organização das Nações Unidas.

Em maio de 2011, o governo federal realoca a Educação Especial na estrutura organizacional do MEC e ela passa a ser uma diretoria de uma secretaria já existente - a Secretaria de Educação Continuada, Alfabetização e Diversidade (SECAD) que passa a se chamar Secretaria de Educação Continuada, Alfabetização, Diversidade e Inclusão $(\text { SECADI })^{20}$ através do Decreto $\mathrm{n}^{\circ}$ $7.480 / 2011^{21}$.

Ainda em 2011, ocorre a criação do "Plano Nacional dos Direitos das Pessoas com Deficiência - Plano Viver sem Limite" a partir do Decreto 7.612/2011. Nesse plano, o governo ressalta o compromisso do Brasil com as prerrogativas da Organização das Nações Unidas (ONU) sobre os direitos das pessoas com deficiência (BRASIL, 2013a). O documento norteador articula políticas governamentais através de ações/programas na área da educação, inclusão social, acessibilidade e atenção à saúde.

No âmbito da educação, o Plano Viver sem Limites possui os seguintes programas: Salas de Recursos Multifuncionais; Escola Acessível; Transporte Escolar Acessível - Programa Caminho da Escola; Pronatec; Acessibilidade na Educação Superior - Incluir; Educação Bilíngue; BPC (Benefício de Prestação Continuada) na Escola. Dos programas citados, destacamos o programa de

\footnotetext{
${ }^{19}$ O Fundo Nacional de Desenvolvimento da Educação (FNDE), autarquia federal criada pela Lei $\mathrm{n}^{\circ}$ 5.537, de 21 de novembro de 1968, e alterada pelo Decreto-Lei n ${ }^{\circ} 872$, de 15 de setembro de 1969 é responsável pela execução de políticas educacionais do Ministério da Educação (MEC). Tem por objetivo transferir recursos financeiros, prestar assistência técnica aos estados, municípios e ao Distrito Federal (BRASIL, 2018).

${ }^{20}$ A SECADI era composta pelas Diretoria de Políticas para a Educação do Campo e Diversidade; Diretoria de Políticas de Alfabetização e Educação de Jovens e Adultos; Diretoria de políticas de Direitos Humanos e Cidadania e Diretoria de Políticas de Educação Especial. A secretaria foi extinta no ano de 2019.

${ }^{21}$ Revogado pelo Decreto 7.690/2012. A estrutura regimental do Ministério da Educação passou por outras modificações: em 2017 o Decreto 7.690/2012 é revogado pelo Decreto 9.005/2017 e mais recentemente em 2019 o Decreto 9.005/2017 é revogado pelo Decreto 9.665/2019.
} 
implantação de Salas de Recursos Multifuncionais, Escola Acessível e Transporte Escolar Acessível, implantados pela rede municipal de Corumbá e relacionados ao público alvo da pesquisa. Abordaremos a política municipal voltada à educação especial em Corumbá no capítulo II.

Dentre os programas da SECADI, Bueno (2016) afirma que o Programa Sala de Recursos Multifuncionais foi o carro chefe da política nacional da educação especial, pois foi o programa que implementou o apoio especializado a alunos da educação especial incluídos no ensino regular da educação básica. Pletsch (2013) afirma que o Plano Viver sem Limite mantém o compromisso do Brasil com a Convenção Internacional sobre os Direitos das Pessoas com Deficiência, tendo no bojo dessas diretrizes e programas, ações que começaram a ser implementadas com o objetivo de intensificar a inclusão social e educacional das pessoas com deficiência.

Nesse contexto, Souza (2013) destaca as análises do Relatório Mundial sobre a Deficiência (WHO; WB, 2011) a respeito das políticas voltadas às pessoas com deficiência implementadas no Brasil. No retrato da situação das pessoas com deficiência no Brasil as preocupações emergem ligadas a pequena quantidade de alunos com deficiência no sistema educacional, sendo a maior quantidade de recursos para os anos iniciais e ensino e ausência de recursos nos anos finais; abandono da escola por alunos com deficiência devido à falta de condições de acesso ao conhecimento e o não cumprimento das leis de acessibilidade, dentre outros fatores.

\begin{abstract}
Em face dos programas e ações descritos, podemos afirmar que, na esteira do movimento histórico, as atitudes do governo dirigidas às pessoas com deficiência estão pautadas pelos princípios da plena participação social e equidade de oportunidades, conforme previsto na Convenção Sobre os Direitos das Pessoas com Deficiência. Contudo, ao mesmo tempo que homologam a legislação vigente estabelecendo políticas regulares e de Estado, e trazem as vozes dos movimentos sociais para dentro do governo, estabelecem políticas de governo por meio de um conjunto de programas esparsos e pontuais com foco em agrupamentos específicos e na redenção dos processos históricos de exclusão (SOUZA, 2013 p. 87).
\end{abstract}

Em 2012, o Decreto $n^{\circ} 7.690 / 2012$ reorganiza a SECADI e cria novas diretorias $^{22}$. Compete à Diretoria de Políticas de Educação Especial a

\footnotetext{
${ }^{22}$ Diretoria de Políticas de Educação do Campo, Indígena e para as Relações Étnico raciais e Diretoria de Políticas de Educação para a Juventude.
} 
implementação da Política Nacional de Educação Especial na Perspectiva da Educação Inclusiva, a oferta do AEE, por meio de ações de apoio técnico e financeiro, ações de formação continuada e a promoção da "transversalidade" e "intersetorialidade" das políticas de educação especial (Rebelo, 2016 grifos da autora).

Bueno (2016) afirma que a incorporação da educação especial pela SECADI pareceu construir um avanço, na medida em que incluiu a política da educação especial dentro de um âmbito mais amplo, da diversidade social e políticas de inclusão. No entanto, o autor enfatiza que embora as ações políticas do Ministério da Educação se voltassem exclusivamente para o apoio ao ensino regular, as instituições privadas de caráter assistencial continuaram recebendo financiamento público.

No ano de 2014 foi publicado o Plano Nacional de Educação (2014 2024) por meio da Lei $n^{\circ} 13.005 / 2014^{23}$. Rebelo (2016) aponta que, mesmo com a expansão das ações das políticas da educação especial, persiste ainda uma correlação de forças entre o setor público e privado, presente durante toda a sua constituição. Ao mesmo tempo que se prioriza o atendimento educacional especializado em salas de recursos multifuncionais, com o objetivo de fortalecer a rede pública de ensino, este atendimento pode ser prestado por instituições privadas de caráter assistencial.

O contexto político do Brasil passou por mudanças importantes nos últimos anos, dentre os acontecimentos destacamos o impeachment da presidente Dilma Rousseff $^{24}$. O governo de Michel Temer (2016 - 2018) apresentou sérias mudanças no contexto educacional brasileiro ${ }^{25}$. As reformas propostas

\footnotetext{
23 A respeito da educação especial, a meta 4 no projeto de lei inicial tinha como objetivo "universalizar, para a população de quatro a dezessete anos, o atendimento escolar aos estudantes com deficiência, transtornos globais do desenvolvimento e altas habilidades ou superdotação na rede regular de ensino" (BRASIL, 2014), porém, após inúmeras mobilizações por parte de instituições especializadas e alterações na redação final, a inserção da oferta nas instituições privadas de caráter assistencial foi inserida.

${ }^{24}$ O segundo mandato de Dilma Rousseff (2015- 2016) manteve o clima de recessão econômica. O país enfrentava uma grave crise política causada pela violenta queda dos preços das commodities exportadas pelo país e por uma série de políticas econômicas equivocadas que produziram uma crise fiscal. No ano de 2016 a presidente Dilma Rousseff sobre impeachment, sendo substituída pelo seu vice, o então presidente Michel Temer.

${ }^{25}$ A exemplo: reforma do ensino médio (instituída pela Lei federal 13.415/2017 ${ }^{25}$ que converteu a Medida Provisória 746/2016 e alterou a estrutura do ensino médio ao implementar a educação em
} 
aprofundam tendências privatistas presentes historicamente na educação pública brasileira e apresenta novos rumos com a ampliação de ações de empresas privadas associadas aos interesses do capital financeiro internacional (MELO E SOUZA, 2017). No campo da educação especial também estão previstas mudanças ${ }^{26}$, no entanto, ainda não é possível sabermos quais serão seus impactos.

Na construção histórica das políticas da educação especial percebemos os avanços e retrocessos que contribuíram para a situação atual, em que o acesso dos alunos com deficiência na escola regular apresentou considerável aumento, porém, ainda são mantidas dificuldades relacionadas à aprendizagem desses indivíduos, devido ao grande número de retenções. Mesmo que eles consigam ocupar os espaços do sistema educacional, outros fatores mostram-se necessários para garantir que esses sujeitos, de fato, tenham as mesmas oportunidades educacionais que as demais pessoas.

É importante lembrar que a maneira como a deficiência é entendida pode ter uma grande influência na implementação das políticas da educação especial, nos mais diferentes níveis de atuação, indo do alto escalão até a burocracia no nível de rua. Nesse sentido, discutimos na próxima seção o papel dos atores responsáveis pela implementação das políticas públicas e como eles podem influenciar nos resultados existentes.

\section{3.}

\section{A implementação das políticas educacionais e discricionariedade dos agentes implementadores}

A implementação constitui parte de um amplo processo no estabelecimento de uma política pública, sendo uma das suas principais dimensões. Souza (2006) afirma que as últimas décadas registraram o

tempo integral, tentativas de privatização da educação (mercantilização), onda de repressão conhecida como "Lei da Mordaça" (Escola sem Partido - PL 867/2015), retirada das questões de gênero da Base Nacional Curricular Comum (Ferreti e Silva, 2017). Além da Emenda Constitucional 241 que cortou os investimentos em saúde e educação para os próximos 20 anos (de 2017 a 2037).

${ }^{26}$ BRASIL (2018) Política de educação especial deverá passar por atualização. Disponível em: http://portal.mec.gov.br/ultimas-noticias/202-264937351/62961-politica-de-educacao-especialdevera-passar-por-atualizacao. 
ressurgimento do campo de conhecimento relacionado às políticas públicas, levando em conta as instituições, regras, modelos que regem sua definição, elaboração, implementação e avaliação.

Com o objetivo de analisar as políticas públicas foram criados diversos modelos explicativos para entender como e porque o governo toma algumas decisões que repercutirão na vida dos mais variados agentes sociais. Dentre eles, destacamos a definição de política pública por meio de tipologias ${ }^{27}$, incrementalismo ${ }^{28}$, ciclo da política pública ${ }^{29}$, garbage can $^{30}$, coalizão de defesa ${ }^{31}$ e arenas sociais ${ }^{32}$, entre outros. Todas as abordagens coadunam com a percepção de que o funcionamento e os resultados das ações do governo pressupõem o reconhecimento da existência de um conjunto amplo de atores, características e procedimentos que irão variar de acordo com a área ou tema específico das políticas públicas (policy issue) (CAVALCANTE, CAMÕES, KNOP, 2015).

Neste trabalho utilizaremos o ciclo de políticas públicas (policy cicle), por considerar que seja a forma mais adequada para realizar a investigação de uma de suas partes. Lima e D’Ascenzi (2013) afirmam que a separação em etapas é

\footnotetext{
${ }^{27}$ Desenvolvido por Theodor Lowi que define que cada tipo de política irá encontrar diferentes formas de apoio e rejeição e que as disputas relacionadas às suas decisões passam por arenas diferenciadas. Segundo Lowi as políticas públicas se dividem em: distributivas, regulatórias, redistributivas, constitutivas.

${ }^{28}$ Lindblom (1979), Caiden e Wildavsky (1980) e Wildavsky (1992) afirmam que as políticas públicas não partem do zero, mas são decisões marginais, incrementais que não levam em conta as mudanças políticas ou mudanças substantivas nos programas.

${ }^{29}$ Nessa concepção a política pública é um ciclo deliberativo composto por estágios, sendo eles: agenda, formulação, implementação e avaliação. Sobre elas iremos discorrer mais profundamente no decorrer do texto.

${ }^{30}$ Desenvolvida por Cohen, March e Olsen (1972) afirma que as escolhas de políticas públicas são feitas como se as alternativas estivessem em uma "lata de lixo" (analogia utilizada para explicar que existem muitos problemas e poucas soluções). As soluções dependem do que os decisores possuem no momento. De acordo com essa definição, as organizações são formas anárquicas que compõem ideias com pouca consistência.

${ }^{31}$ Proposto por Sabatier e Jenkins-Smith (1993) define que a política pública deve ser concebida como um conjunto de subsistema relativamente estável, que se articula com conhecimentos externos. Segundo esse modelo cada subsistema da política pública é composto por um número de coalizões de defesa que se distinguem através por meio de valores, crenças e ideias e pelos recursos que dispõem.

${ }^{32}$ Vê a política como uma iniciativa dos empreendedores políticos ou de políticas públicas. Leva em conta que para uma determinada circunstância ou evento se transforme em um problema, é preciso que as pessoas sejam convencidas de que alguma coisa precisa ser feita. É nesse momento que os policy makers dos governos (aqueles que fazem as políticas públicas) passam a prestar atenção em algumas questões e ignoram outras.
} 
frequentemente utilizada para realização da análise de uma política pública. De acordo com este modelo, o ciclo da política pública é composto pelas seguintes fases: agenda, formulação, implementação e avaliação. $O$ ciclo das políticas públicas também é conhecido como policymaking (CAVALCANTE, CAMÕES, KNOP, 2015).

A respeito da construção da Agenda a questão se refere aos argumentos teóricos de como são construídas as decisões e assuntos que serão apresentados e debatidos na esfera pública (LOTTA, 2014). A fase de Formulação inclui a seleção e especificação da alternativa considerada mais conveniente (SARAVIA, 2006). Já a implementação se refere ao momento em que a política entra em ação e é colocada em prática. (LOTTA, 2006). A última fase no ciclo da política consiste na fase de Avaliação. Esta fase pode acontecer em diversos momentos da implementação (monitoramento) ou após a implementação. Os estudos sobre implementação de políticas públicas estão atrelados às necessidades de desenvolvimento e melhoria nos processos político-administrativos (LIMA e D’ASCENZI, 2013). A análise dessa fase tem sido entendida como uma das dimensões cruciais (senão a variável central) para a explicação do insucesso dos governos em atingir os objetivos do desenho das políticas públicas. A implementação constitui o "elo perdido" nas discussões sobre eficiência e eficácia da ação do governo (SILVA E MELO, 2000 grifos dos autores).

Lotta (2010) afirma que uma das lacunas existentes ${ }^{33}$ nas análises da implementação de políticas públicas relaciona-se à incorporação de outros atores, considerando os processos de interação, mediação e os referenciais dos agentes inseridos na implementação.

Nesse sentido, o próximo item aborda a temática os agentes implementadores, apresentando os conceitos referentes aos Burocratas de Médio Escalão (BME) e Burocratas de Nível de Rua (BNR).

\footnotetext{
${ }^{33}$ Até os anos de 1970 os estudos sobre implementação de políticas públicas eram focados nos processos de tomada de decisão, assumindo-a de maneira hierárquica (de cima para baixo). Nessa vertente, a política era considerada um processo dinâmico e a inserção de atores no processo não era levada em conta (Barret, 2004).
} 


\subsection{1.}

Os agentes implementadores: a discricionariedade dos burocratas de médio escalão e dos burocratas de nível de rua.

O campo de estudos das análises de implementação de políticas públicas que consideram influência dos agentes implementadores no processo podem ser explicadas através de duas perspectivas: top-down e bottom-up. O modelo topdown diz respeito a uma estrutura tradicional de governo e organização do setor público, com ênfase na separação de política e administração, coordenação e controle por meio de autoridade e hierarquia. Já o modelo bottom-up considera a implementação como parte de um processo contínuo em que os agentes envolvidos têm a possibilidade de modificar suas ações ao longo do percurso (BARRET, 2004).

Lotta (2015) afirma que na perspectiva top-down o foco é a prescrição, o que deve ser feito. A crítica a essa abordagem é a ausência de descrições profundas sobre os processos e suas complexidades. A visão bottom-up tende a focar o entendimento e a explicação e sua principal crítica é a ausência de prescrições para a prática. Outro ponto importante no que diz respeito à descrição e prescrição apontado por Lotta (2015) refere-se ao que se entende por implementação, se o conceito está relacionado à conformação ou ao desempenho. A conformação diz respeito à comparação entre a formulação das políticas e seus resultados, já o desempenho refere-se ao processo de implementação. Neste trabalho o foco será no desempenho da implementação das políticas da educação especial.

Outro fator importante na análise da implementação de políticas públicas diz respeito à discricionariedade dos agentes implementadores. Os estudos sobre a discricionariedade apresentam diferentes pontos de vista quanto à sua amplitude. De um lado existe o ponto de vista de que a discricionariedade do agente está presente em praticamente todos os níveis do processo de implementação, onde quer que os limites de seu poder permitam fazer uma escolha entre possíveis cursos de ação ou inação (Davis, 1969). Por outro lado, existem definições restritivas do conceito de discricionariedade, atribuindo-a a agentes específicos em situações particulares (BULL, 1980; DONNISON, 1977). 
De acordo com Ham e Hill (1993) a discricionariedade pode ser analisada em dois níveis, sendo um amplo e outro mais restrito. O primeiro é totalmente isento de valores e considera o estudo da discricionariedade a partir da identificação de sua influência e das regras estabelecidas, além de considerar a maneira como os agentes desenvolvem a implementação, levando em conta as forças políticas, sociais e econômicas maiores. No outro nível, os estudos visam entender quem ganha o quê em função de uma configuração particular de regras e discricionariedade, além de considerar as mudanças concretas que alteram o processo. Neste nível as preocupações referentes aos interesses de ganhadores e perdedores são trazidas à cena.

No presente trabalho o conceito de discricionariedade será utilizado levando em consideração a interação dos agentes. A análise da dinâmica interativa existente por trás das políticas públicas será um dos focos do presente trabalho. Para tanto é necessário entendermos também o contexto burocrático de implementação das políticas públicas.

Faria (1983) ao examinar a contribuição dos estudos de Max Weber, considerando sua influência nos estudos relacionados à Administração afirma que a organização burocrática é tecnicamente superior a outras formas de organização. $\mathrm{O}$ autor conceitua a burocracia da seguinte forma:

\begin{abstract}
A burocracia é, para quem controla seu aparato, um eficiente instrumento de poder, pois atrela o funcionário à sua atividade; controla os meios e canal de comunicações; impõe normas de conduta; regula extensamente os fluxos de informação; determina os níveis de sigilo ("segredo oficial"); indica a forma e o conteúdo do processo de recrutamento; promove, a todos os níveis e de uma forma bastante intensa, o desenvolvimento de uma objetividade de cunho eminentemente racional (FARIA, 1983 p.28).
\end{abstract}

Faria e Meneghetti (2011) afirmam que a burocracia estabelece relações de autoridade delimitadas por normas e por meio da definição de postos e níveis de autoridade. Nesse contexto, a administração se formaliza através de documentos que regulam a conduta e as atividades das pessoas. $\mathrm{O}$ cumprimento dos objetivos efetiva-se por tarefas definidas que devem ser realizadas, independente das características relacionadas a critérios pessoais. Dessa forma, a burocracia na visão weberiana apresenta características racionais, nas quais as regras, meios fins e objetivos são primordiais no desenvolvimento das atividades. 
Para Weber, o burocrata é um fiel executor de serviços que deve aplicar fielmente as regras observando os procedimentos, garantindo cumprimento da hierarquia e das atribuições. Nesse sentido, não haveria nessa relação espaço para discricionariedade. Ao longo dos anos e com a modernização do papel do Estado, novos estudos ganham espaço no campo acadêmico, identificando a complexidade do papel dos burocratas (LOTTA, 2015). Nesse sentido, o modelo tradicional de interpretação dos mecanismos das políticas públicas abriu espaço para outras formas de análise que consideram diferentes níveis do processo de implementação. Destacamos no presente trabalho os Burocratas de Médio Escalão e os Burocratas de Nível de Rua.

Os burocratas de médio escalão ${ }^{34}$ consistem nos "gerentes, dirigentes, supervisores e agentes encarregados de operacionalizar as estratégias definidas nos altos escalões da burocracia" (PIRES, 2011 p.3). Já os burocratas de nível de rua (Street-level-bureaucrats) são os agentes implementadores que interagem diretamente com os cidadãos e lhes concedem (ou não) acesso a programas e serviços, aplicam sanções etc. (Lipsky, 2010). As ações desses profissionais têm impacto considerável na vida das pessoas em geral, particularmente dos usuários dos serviços públicos, pois determinam a elegibilidade dos cidadãos para acessar os serviços oferecidos pelo governo.

Os burocratas de médio escalão atuam no nível intermediário da política pública localizados entre o topo e a base. Pires (2011) afirma que esses atores estão "espremidos" tanto do ponto de vista prático, devido à sua posição na estrutura organizacional e suas prerrogativas, quanto do ponto de vista teórico entre as abordagens que focam o alto escalão e o chamado "nível de rua" (grifos do autor).

Lotta, Pires e Oliveira (2015), no que tange ao serviço público, destacam que os estudos sobre a burocracia de médio escalão possuem como questão central a consideração de que os valores e motivações dos burocratas são distintos e podem ser afetados por questões institucionais ou organizacionais. Sua atuação

\footnotetext{
${ }^{34}$ Lotta, Pires e Oliveira (2015) afirmam que existe na literatura certa ambiguidade e dificuldade em definir com exatidão o que caracteriza um burocrata de nível de rua, sendo a forma mais frequente de definição a que se relaciona à identificação dos funcionários situados no meio da estrutura hierárquica da organização.
} 
está voltada para as atividades internas à organização e, consequentemente a sua interação é mais frequente com superiores, subordinados e colegas do que com atores externos. Finalmente, Freire, Viana e Palotti (2015) definem o burocrata de médio escalão como o profissional responsável pela intermediação entre técnica e política. Eles assessoram o alto escalão e são responsáveis pela articulação dos processos de trabalho internos.

Já a Street-Level Bureaucracy ou burocracia do nível de rua consiste no termo traduzido literalmente para a língua portuguesa criado por Michael Lipsky para descrever os agentes responsáveis pelo nível operacional das políticas públicas. Esses agentes, de acordo com Lotta (2014) são foco de controvérsia, pois são pressionados pelas demandas de serviços para aumentar efetividade e responsividade e, ao mesmo tempo, sofrem pressão dos cidadãos para elevar a eficiência e eficácia dos serviços. A autora afirma que existem duas razões centrais para eles dominarem a controvérsia política nos serviços públicos: os debates sobre o escopo e foco dos serviços públicos que estão diretamente relacionados à função exercida por eles; e o fato de que eles possuem grande impacto na vida das pessoas.

Araújo Filho (2014) enfatiza que a teoria da burocracia do nível de rua possui como perspectiva central os dilemas individuais dos funcionários que trabalham diariamente com as políticas públicas, colocando-as em prática. Eles lidam diretamente com o público e com os conflitos decorrentes dessas interações. "Por meio de sua abordagem aproximada da realidade dos indivíduos que operacionalizam as políticas públicas, os estudos de burocracia do nível de rua têm um ponto de vista privilegiado do processo de conhecimento dos serviços governamentais" (p. 47-48). Essa posição contribui para que o burocrata do nível de rua tenha amplitude de escolha como "realizador da política pública". Essa posição está pautada em dois elementos: seu relativo poder discricionário e a relativa autonomia das autoridades organizacionais (idem).

A heterogeneidade dos atores se dá tanto pelo contexto setorial e institucional quanto pelos cargos exercidos por cada um deles (LOTTA, PIRES E OLIVEIRA, 2015). No presente trabalho, os diretores e coordenadores serão considerados os burocratas de médio escalão, porém, em determinados momentos 
atuando como burocratas de nível de rua e os professores regentes, profissionais de apoio e professores do atendimento educacional especializado, burocratas de nível de rua. Buscaremos conhecer o ponto de vista desses agentes a respeito da política da educação especial e suas interações. Além de verificarmos a existência (ou não) de discricionariedade nessas relações.

A esse respeito, Lotta (2015) ressalta que "as instituições impactam as práticas, mas as ações, valores, referências e contextos dos indivíduos também impactam as instituições” (p.47). Oliveira (2017) também afirma que o exercício da discricionariedade dos "fazedores" 35 " das políticas públicas é "influenciado por suas ideias, crenças e valores, o que torna significativo o estudo de suas percepções" (p.181).

Oliveira (2017) aponta, ainda, que a discricionariedade dos agentes ocorre não porque não haja normas que os constranjam, mas porque as regras formais, nem sempre dão conta de todos os casos com que esses funcionários lidam e muitas vezes os recursos são escassos para a prestação de determinado serviço. Esses fatores, somados à imprevisibilidade do trabalho, faz com que eles tomem decisões sob pressão direta do público, sem o mesmo tempo de reflexão de que dispõem os formuladores das políticas.

Maynard-Moody e Musheno (2003) destacam que as leis e as normas estão presentes no cotidiano do trabalho dos burocratas implementadores, no entanto, elas coexistem com as tensões do trabalho em nível de rua, revelando uma necessidade de compreensão mais profunda sobre as tomadas de decisões, considerando principalmente os motivos existentes. Com o objetivo de mostrar a complexidade dessa relação, suas práticas e efeitos, os autores descrevem dois tipos de narrativas: como agente do Estado (state-agent narrative) e como agente do cidadão (citizen-agent narrative).

Os agentes do Estado são aqueles que baseiam seu trabalho no cumprimento da lei, que baseiam a sua perspectiva e suas decisões de acordo com as ações equivalentes à política. Sua narrativa é sobre a obediência à lei, tanto para cidadãos quanto para trabalhadores. Já o agente do cidadão atua conforme

\footnotetext{
${ }^{35}$ Referência aos burocratas do nível de rua.
} 
julgamentos feitos sobre as identidades e caráter moral do público alvo das políticas, identificando aqueles que são merecedores daqueles que não são merecedores. Ambas as narrativas são interligadas em seus significados e propósitos no contexto do estado moderno, por vezes elas coexistem e convergem (leis, políticas públicas, normativas da instituição, por exemplo) e por vezes as decisões ocorrem de acordo com a visão dos agentes, no que diz respeito ao seu senso de justiça e à visão acerca da decisão correta. As visões divergem no momento em que as normativas legais entram em conflito com as crenças dos agentes no que se refere ao que é certo fazer (MAYNARD-MOODY E MUSHENO, 2003).

Os "agentes do cidadão" baseiam suas ações na discricionariedade, o que não significa que esses agentes não tenham sua ação restringida por regras, regulamentos e diretrizes superiores, uma vez que as políticas públicas são formuladas em outras instâncias de maior nível hierárquico (LIPSKY, 2010). Oliveira (2017) afirma que o exercício da discricionariedade, a exemplo da atuação do "agente do Estado" proposto por Maynard-Moody e Musheno, gira em torno de uma fidelidade legal, enquanto o "agente do cidadão" baseia sua atividade em uma espécie de fidelidade moral ou cultural, que leva em conta os cidadãos dignos ou não de usufruir de um serviço diferenciado. Dessa forma, os agentes avaliam o cidadão em questão e depois recorrem à política para respaldar sua decisão, caso não encontrem suporte legal, racionalizam suas decisões com base em outras formas de legitimação, que podem estar relacionadas, inclusive, ao seu saber pragmático advindo da experiência próxima à realidade da linha de frente.

Para entender de que maneira ocorre a implementação de uma determinada política pública, Lima e D’Ascenzi (2013) ressaltam que devem ser considerados fatores relacionados às características do plano da política, a organização do aparato administrativo responsável pela implementação e as ideias, os valores e as concepções de mundo dos indivíduos. Dentre os fatores, ao analisarmos as políticas voltadas às pessoas com deficiência, daremos maior atenção ao fator que está relacionado às ideias, valores e concepções de mundo dos implementadores acerca do conceito de deficiência, ideias que conformam a percepção que os 
agentes implementadores têm dos potenciais usuários da política e influenciam sua ação. Consideraremos também o contexto em que estão inseridos, suas condições de trabalho e as características intersetoriais do desenho da implementação das políticas de educação especial na rede municipal de Corumbá, sobre a qual discorreremos no próximo capítulo, apresentando a rede municipal de ensino de Corumbá, o histórico da educação especial no município e o campo de pesquisa. 


\section{2 \\ O CAMPO DA PESQUISA: a rede municipal de ensino de Corumbá e a educação voltada às pessoas com deficiência.}

A pesquisa foi realizada no município de Corumbá, tríplice fronteira oeste do Mato Grosso do Sul. Corumbá faz divisa com a Bolívia e o Paraguai. A cidade mantém relações próximas com as cidades de Puerto Suarez e Puerto Quijarro (Bolívia) enquanto sua fronteira com o Paraguai é alagada.

Figura 1: Corumbá, Mato Grosso do Sul, Brasil.

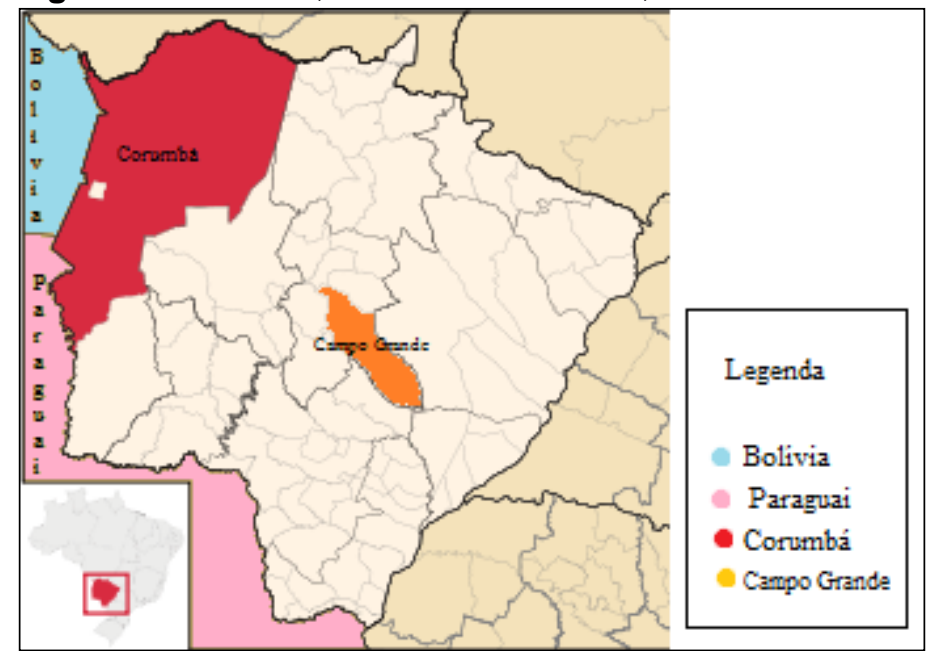

Fonte: Adaptado de Wikipedia, 2017.

A abertura da livre navegação, após a Guerra do Paraguai, propiciou expressivo movimento de pessoas e de mercadorias no Porto de Corumbá entre final do século XIX e o início do XX. Com o crescimento considerável ${ }^{36}$ do comércio e das exportações a cidade passou a ser o principal entreposto comercial da Província de Mato Grosso e polo catalisador do desenvolvimento de toda a região sul da província. Porém, após a chegada da Estrada de Ferro Noroeste do

\footnotetext{
36 "Um álbum gráfico editado em 1914, em Hamburgo, relata que cento e quarenta e dois navios do Brasil, Argentina, Uruguai e Paraguai, aportaram em Corumbá naquele ano, dos quais seis eram do Lloyd Brasileiro. Os navios da Companhia Lloyd advindos de outros países levavam, basicamente, as peles de animais silvestres, a erva mate, o charque e a borracha" (VIANNA, et.al., 2002). O Lloyd era uma Companhia de Navegação existente em várias localidades do mundo: Argentina, Cuba, Honduras, Uruguai, América,Canadá, Brasil, México,Chile, entre outros (Giraud, 2011).
} 
Brasil (NOB) ocorreu uma considerável diminuição do comércio por vias fluviais, o que contribuiu para a decadência do município (Manetta, 2009).

Com população estimada de 110.806 habitantes em 2018 (IBGE, 2018) Corumbá possui como atividades econômicas principais a extração mineral, pecuária e o turismo. Conforme os dados do IBGE, seu Índice de Desenvolvimento Humano Municipal (IDHM ${ }^{37}$ ) é de 0,700, o que o classifica como alto, ainda que esteja no limite inferior $\operatorname{desta~}^{38}$. O estado de Mato Grosso do Sul apresenta índice um pouco maior $(0,729)$, tendo como dimensão mais proeminente a Longevidade ${ }^{39}$, com índice de 0,833 e o pior indicador a Educação com 0,629. O IDHM de Corumbá também tem entre suas dimensões mais elevadas a Longevidade $(0,834)$. Vale ressaltar que, no que se refere à Educação, o município apresenta índice de 0,586, considerado baixo. (PNUD, 2013).

\section{1.}

\section{A rede municipal de ensino de Corumbá/MS: o recorte da pesquisa}

Conforme os dados do Censo Escolar do ano de 2016, o município de Corumbá possui $26.330^{40}$ alunos matriculados na Educação Básica em suas 61 instituições de ensino. O Censo registra que 493 deles possuem algum tipo de deficiência (Censo Escolar/INEP, 2017). Para melhor visualização das informações referentes às instituições escolares do município de Corumbá, vejamos a tabela a seguir:

\footnotetext{
${ }^{37}$ O Índice de Desenvolvimento Humano Municipal é uma medida composta de indicadores de três dimensões do desenvolvimento humano: longevidade, educação e renda. O índice varia de 0 a 1. Quanto mais próximo de 1, maior o desenvolvimento humano (PROGRAMA DAS NAÇÕES UNIDAS PARA O DESENVOLVIMENTO NO BRASIL, 2017).

${ }^{38}$ A classificação do IDHM é caracterizada da seguinte forma: 0 a 0,499 - Muito Baixo; 0,500 a 0,599 - Baixo; 0,600 a 0,699 - Médio; 0,700 a 0,799 - Alto e; 0,800 a 1,00 - Muito Alto (PNUD, 2013).

${ }^{39}$ Esperança de vida ao nascer

${ }^{40}$ As informações apresentadas nesse item foram retiradas dos microdados do Censo Escolar 2016. Para construção das tabelas e gráficos utilizamos o software IBM Statistical Package for the Social Sciences - SPSS, o software de análise de dados mais utilizado nas ciências sociais e humanas (MARÔCO, 2011).
} 
Tabela 1: Quantidade de alunos matriculados na educação básica das escolas de Corumbá (MS) conforme dependência administrativa em $2016^{41}$.

\begin{tabular}{ccccc}
\hline $\begin{array}{c}\text { Dependência } \\
\text { Administrativa }\end{array}$ & $\begin{array}{c}\text { Escolas } \\
\text { Urbanas }\end{array}$ & $\begin{array}{c}\text { Número de alunos } \\
\text { (urbanas) }\end{array}$ & $\begin{array}{c}\text { Escolas } \\
\text { Rurais }\end{array}$ & $\begin{array}{c}\text { Número de } \\
\text { alunos } \\
\text { (rurais) }\end{array}$ \\
\hline Municipal & 24 & 12.287 & 11 & 1.239 \\
Estadual & 10 & 8.970 & 1 & 11 \\
Federal & 1 & 374 & - & - \\
Privada & 14 & 3.448 & - & 1 \\
Total & 49 & $\mathbf{2 5 . 0 7 9}$ & $\mathbf{1 2}$ & $\mathbf{1 . 2 5 1}$ \\
\hline
\end{tabular}

Fonte: Elaboração própria com base nos Microdados do Censo Escolar, MEC/INEP, 2017.

Os dados mostram que a grande maioria dos estudantes está matriculada na rede municipal de ensino, o que também justifica a escolha desta dependência administrativa para a pesquisa, acrescentado ao fato do município implementar as políticas públicas do governo federal frequentemente, como poderemos verificar mais adiante ao apresentarmos o histórico das políticas da educação especial, nessa localidade.

As escolas da rede municipal são classificadas de acordo com tipologias. O Decreto Municipal $\mathrm{n}^{\circ} 2018$ de 25 de julho de 2018 determina a estrutura organizacional das escolas delimitando o quadro de profissionais que atuarão na escola. A tipologia é definida a partir dos seguintes critérios: quantidade de alunos matriculados, etapas de ensino, oferta de EJA, localização (urbana ou rural) e número de extensões. Cada um dos critérios elencados apresenta pontuação que define a classificação das escolas ${ }^{42}$ (Corumbá, 2018).

\footnotetext{
${ }^{41}$ Nos dados existe uma escola cadastrada no município de Corumbá de maneira equivocada. Por isso a existência de uma única matrícula na rede privada em escola rural, apesar de não existir registro no Censo de escolas privadas rurais no município de Corumbá.

${ }^{42}$ As escolas que apresentam de 9 a 15 pontos classificam-se como tipologia A, de 7 a 8,9 pontos como tipologia B, de 3 a 6,9 pontos como C e até 2,9 pontos como tipologia D (Corumbá, 2018). A tabela com a pontuação de cada critério encontra-se no anexo deste trabalho.
} 
Tabela 2: Organização dos cargos e funções conforme tipologia das escolas da rede municipal de Corumbá.

\begin{tabular}{|c|c|c|c|c|c|}
\hline \multirow{2}{*}{ Cargo } & \multirow{2}{*}{ Função } & \multicolumn{4}{|c|}{ Tipologia } \\
\hline & & A & B & C & $\mathrm{D}$ \\
\hline \multirow{3}{*}{$\begin{array}{l}\text { Profissional de } \\
\text { educação }\end{array}$} & Diretor de escola & 1 & 1 & 1 & 1 \\
\hline & Diretor Adjunto & 1 & - & - & - \\
\hline & $\begin{array}{l}\text { Especialista em Educação e/ou } \\
\text { professor coordenador }\end{array}$ & 3 & 2 & 1 & 1 \\
\hline \multirow{2}{*}{$\begin{array}{l}\text { Técnico de } \\
\text { Educação Escolar I e } \\
\text { II }\end{array}$} & Secretário de Escola & 1 & 1 & 1 & 1 \\
\hline & Auxiliar de Secretaria & 2 & 1 & - & - \\
\hline \multirow{2}{*}{$\begin{array}{l}\text { Agente de apoio } \\
\text { escolar II }\end{array}$} & Agente de disciplina escolar & 4 & 3 & 2 & 1 \\
\hline & Agente de merenda & 2 & 2 & 2 & 1 \\
\hline \multirow{2}{*}{$\begin{array}{l}\text { Agente de apoio } \\
\text { escolar I }\end{array}$} & Auxiliar de agente de merenda & 2 & 2 & 1 & - \\
\hline & $\begin{array}{c}\text { Agente de limpeza, conservação, } \\
\text { manutenção e lavanderia }\end{array}$ & 6 & 4 & 3 & 2 \\
\hline
\end{tabular}

Fonte: Anexo III do Decreto 2.018 de 25 de julho de 2018 (CORUMBÁ, 2018).

Todas as escolas que participaram da fase empírica da pesquisa são classificadas como de Tipologia A.

Quanto à quantidade de alunos nas diferentes etapas de ensino, a maior parte dos estudantes do município de Corumbá frequenta os anos iniciais do Ensino Fundamental, seguido dos matriculados nos anos finais do Ensino Fundamental e na Educação Infantil, como podemos ver de maneira detalhada na tabela a seguir.

Tabela 3: Quantidade de alunos nas redes de ensino urbanas de Corumbá (MS) conforme a etapa de ensino e dependência administrativa em 2016.

\begin{tabular}{lccccccc}
$\begin{array}{c}\text { Dependência } \\
\text { Administrativa }\end{array}$ & $\begin{array}{c}\text { Ed. } \\
\text { Infantil }\end{array}$ & $\begin{array}{c}\text { Anos } \\
\text { iniciais do } \\
\text { Ens. Fund. }\end{array}$ & $\begin{array}{c}\text { Anos finais } \\
\text { do Ens. } \\
\text { Fund. }\end{array}$ & $\begin{array}{c}\text { Ensin } \\
\mathbf{0} \\
\text { Médio }\end{array}$ & $\begin{array}{c}\text { EJA } \\
\text { Ens. } \\
\text { Fund. }\end{array}$ & $\begin{array}{c}\text { EJA } \\
\text { Ens. } \\
\text { Médio }\end{array}$ & Total \\
\hline Municipal & 2.876 & 5.410 & 2.850 & - & 1.045 & - & 12.181 \\
Estadual & - & 1.762 & 2.772 & 2.636 & 212 & 1.159 & 8.541 \\
Federal & - & - & - & 204 & - & 2 & 206 \\
Privada & 569 & 1.301 & 733 & 517 & & 7 & 3.127 \\
Total & 3.445 & 8.473 & 6.355 & 3.357 & 1.257 & 1.168 & 24.055 \\
\hline
\end{tabular}

Fonte: Elaboração própria com base nos Microdados do Censo Escolar, MEC/INEP, 2017.

A maior quantidade de alunos na rede municipal também está ligada ao fato desta dependência administrativa possuir maior número de unidades 
escolares, tanto na zona urbana, quanto na zona rural. Nesse sentido, a rede municipal de ensino, no ano de 2016 foi a dependência administrativa que apresentou maior quantidade de alunos com deficiência, como podemos ver no gráfico a seguir:

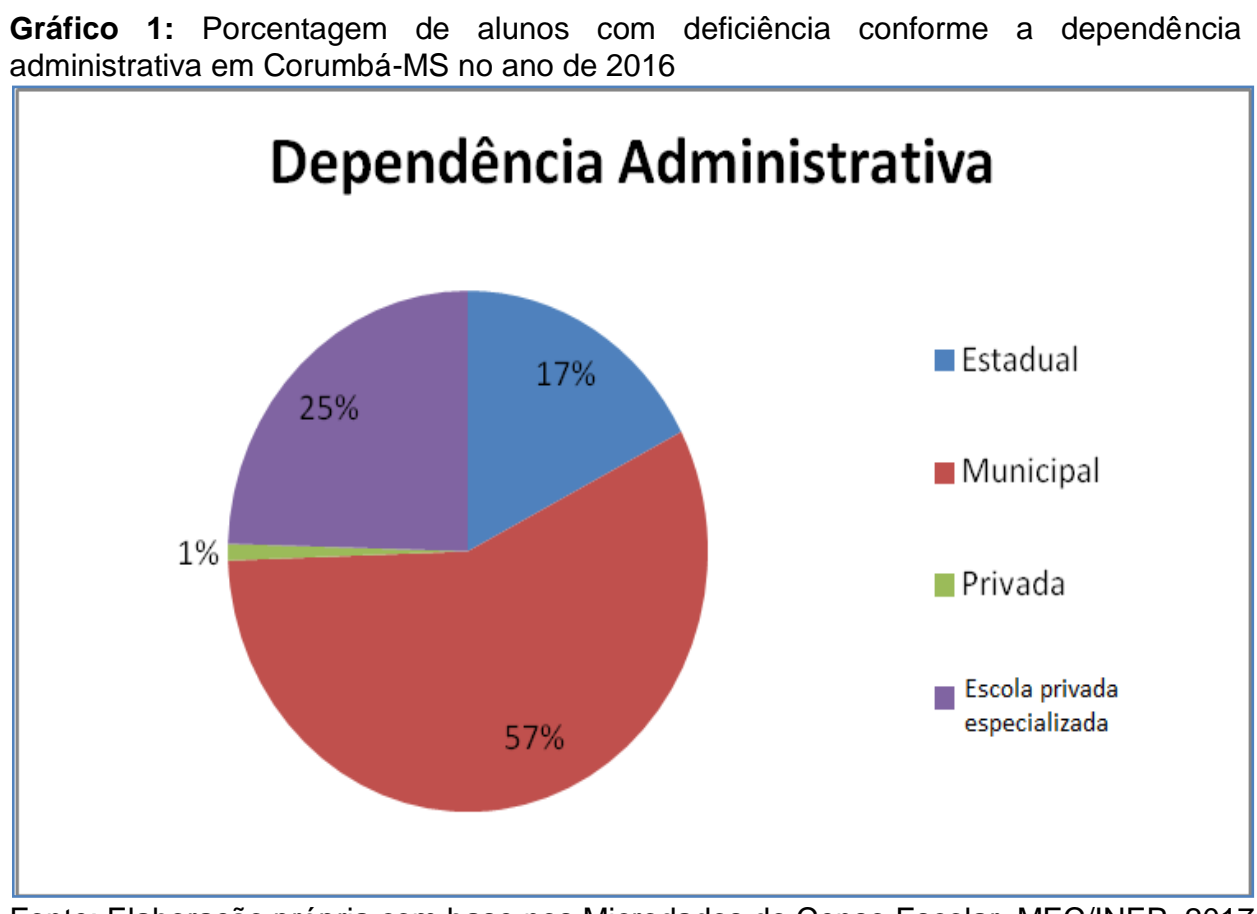

Fonte: Elaboração própria com base nos Microdados do Censo Escolar, MEC/INEP, 2017.

Entendemos que o aumento das matrículas de alunos com deficiência, além de estar relacionado com o avanço na universalização da educação básica, tem relação também com a implementação de políticas educacionais voltadas às pessoas com deficiência. A quantidade de pessoas com deficiência matriculadas nesta dependência administrativa pode estar relacionada aos resultados dessas políticas, além de refletir as iniciativas próprias do município no atendimento a essa população.

Considerando que nosso foco de pesquisa são os agentes implementadores da política educacional voltada aos alunos com deficiência, incluindo nessa população os diretores escolares, é necessário entendermos como ocorre a escolha dos diretores na rede municipal de educação em Corumbá. Para tanto, apresentaremos a legislação concernente à escolha da direção escolar nas escolas da rede municipal de ensino de Corumbá. A escolha é regida pela Lei Municipal 
$n^{\circ} 2.264 / 2012$ que dispõe sobre a gestão democrática do ensino público municipal e fixa regras para a eleição dos diretores e do colegiado escolar ${ }^{43}$ da rede municipal. O acesso ao cargo de diretor de escola fica a critério de cada unidade de federação (OLIVEIRA, 2015).

O diretor exerce sua autoridade de formas variadas, considerando sua trajetória pessoal, formação acadêmica e experiência no exercício do cargo ou em outros setores educacionais. Oliveira (2015) afirma que as estratégias adotadas na condução da escola envolvem negociações, diálogos e decisões e o nível de participação e abertura existentes entre a direção e os demais agentes escolares. A gestão escolar pode ser entendida como um processo político de disputa de poder (explícita ou não), por meio do qual as pessoas agem na/sobre a escola pautandose predominantemente por seus próprios olhares e interesses sobre todos os passos desse processo (SOUZA, 2006). De acordo com o autor, a gestão escolar é uma espécie de braço executivo da política.

Em Corumbá, a Lei Municipal no 2.264 de 23 de agosto de 2012 define a seleção dos diretores da rede municipal da seguinte forma: realização de prova de títulos dos últimos cinco anos; curso de Gestão Escolar; avaliação de competências básicas de dirigentes, por meio de prova escrita; construção de um Banco Único de Dados com o registro dos habilitados a participarem da eleição; elaboração e apresentação de projeto de gestão à comunidade escolar; assinatura do Contrato de Gestão; e eleição. O mandato dos diretores possui duração de três anos.

Em 2016 a Lei Municipal $n^{\circ} 2.550$ retira a obrigatoriedade da construção do banco de dados com o registro dos habilitados a participarem da eleição, mas mantém a consulta à comunidade por meio do artigo $5^{\circ}$ da lei $2.264^{44}$.

Já em dezembro de 2017, a prefeitura publica a Lei Complementar $n^{\circ}$ $216^{45}$. A partir daí a ocupação do cargo de diretor das escolas da rede municipal

\footnotetext{
${ }^{43} \mathrm{O}$ colegiado escolar e a direção integram a Direção Colegiada, instância máxima do processo decisório, de iniciativa e propositura de projetos e atividades na unidade escolar. O colegiado é órgão de caráter deliberativo, executivo, consultivo e avaliativo, da gestão democrática pedagógica, administrativa e financeira, dos estabelecimentos de ensino, respeitadas as normas legais vigentes (CORUMBÁ, 2012).

44 "A consulta à comunidade escolar para a escolha da Direção, com voto direto, secreto e proporcional, prova de título e curso de gestão escolar" (CORUMBÁ, 2016).
} 
de ensino mantém os mesmos critérios, porém, retira-se a eleição do processo. A obrigatoriedade do banco de dados volta a ser obrigatória, com a alteração da lei 2.250. A partir do banco de dados, a consulta à comunidade escolar é realizada, porém, a escolha do diretor é realizada pelo prefeito municipal, que pode acatar o candidato escolhido pela comunidade ou não.

Em junho de 2018, a prefeitura sanciona nova lei complementar que mantém o curso de gestão, a avaliação de competências básicas de dirigente e a constituição do banco único de dados. A partir dessa lei, o inciso I do artigo $5^{\circ}$ (que previa a consulta à comunidade para escolha do diretor) é alterado e passa a vigorar da seguinte forma: "participação no processo de capacitação para o exercício da função de gestor escolar e composição de banco único de dados" (CORUMBÁ, 2018).

Assim, a escolha para o cargo de diretor na rede municipal de Corumbá passa a ser por meio de um processo seletivo e não eletivo, que pode envolver uma consulta à comunidade, mas que será referendada pelo prefeito, que pode acatar a opinião popular ou indicar outro diretor que componha o banco único de dados.

Quanto à gestão da Secretaria Municipal de Educação destacamos a grande rotatividade de seus membros. Nos últimos anos, a Secretaria Municipal de Educação sofreu três alterações em sua equipe diretiva (secretários, gerentes, chefes de núcleos, supervisores).

Durante a gestão do prefeito Paulo Duarte (2013 - 2016) a Secretaria de Educação contava com uma equipe que permaneceu até o final de 2017. No ano de 2018, com a posse do prefeito Ruiter Cunha de Oliveira, que já havia estado no cargo por dois mandatos, de 2005 a 2012, ocorreu alteração de toda a equipe da secretaria de educação. Em novembro do mesmo ano, o prefeito Ruiter falece. Quem assume a prefeitura de Corumbá é seu vice, Marcelo Iunes, que realiza mais uma vez a alteração de toda a equipe diretiva da Secretaria de Educação, sendo a terceira mudança em aproximadamente 2 anos.

\footnotetext{
${ }^{45}$ Altera a Lei Complementar $\mathrm{n}^{\circ} 150$ (institui o Plano de Carreira e Remuneração do Magistério Municipal de Corumbá) e a Lei no 2.250 .
} 
O processo de escolha dos diretores sofreu os reflexos dessas mudanças, pois as leis foram implementadas por três prefeitos diferentes. No ano de 2012, o prefeito Ruiter Cunha de Oliveira sancionou a lei que estabelece que a escolha do diretor seria democrática, trazendo inclusive esta palavra na descrição do documento legal. Em 2016, o prefeito Paulo Duarte realiza alterações retirando o banco único de dados, porém, mantendo a consulta à comunidade com voto proporcional. Já em 2017, o prefeito Marcelo Iunes retira o termo "democrático" da legislação e altera o processo retirando também os artigos referentes à eleição dos diretores. Em 2018 o pleito é oficialmente composto por critérios que o caracterizam como um processo seletivo e não uma escolha democrática.

A retirada das características democráticas da escolha dos diretores caracteriza um retrocesso, uma vez que a escolha popular não representa mais o principal critério para a escolha do diretor. Paes de Carvalho e Oliveira (2018) afirmam que escolhas democráticas de diretores influenciam positivamente os resultados dos alunos. A alta rotatividade da equipe responsável pela Secretaria Municipal de Educação também possui grande impacto na implementação das políticas públicas, uma vez que o trabalho pode não apresentar continuidade.

\section{2.}

\section{A educação especial na rede municipal de Corumbá/MS.}

Os primeiros registros de atendimento educacional voltado à pessoa com deficiência no município acontecem em 1971 a partir do surgimento de uma instituição privada de caráter assistencial, de acordo com os documentos da Secretaria Municipal de Educação. Em 1975, as classes especiais começam a ser implantadas nas escolas públicas da rede estadual e em 1977 duas salas especiais são implantadas na rede municipal, sendo transferidas para o estado em 1978. Já nos anos finais da década de 1980 ocorreu a abertura da primeira sala de recursos, na área de deficiência visual, na rede municipal de ensino (LOBO, 2011).

A oferta do atendimento educacional às pessoas com deficiência no município ocorre após a Constituição de 1988, com o processo de municipalização. O Sistema Municipal de Ensino também foi criado nesse 
contexto, por meio da Lei Municipal $n^{\circ}$ 1.523/1996 definindo a atuação prioritária no ensino fundamental e na educação infantil (CORUMBÁ, 1996).

No ano de 1997 foi implantado no município o Centro Regional de Integração Especial (CRIE), vinculado ao Centro de Atendimento Integral à Criança (CAIC/Pe. Ernesto Sassida), por meio da Secretaria Municipal de Educação, oferecendo apoio pedagógico aos alunos que apresentavam dificuldades no processo de ensino-aprendizagem. O centro contava com salas de recursos para alunos com deficiência auditiva, física, intelectual, visual e distúrbio de aprendizagem, além da oferta de cursos pré-profissionalizantes (Rodrigues, 2017).

A cidade de Corumbá tem acompanhado o contexto nacional das políticas públicas da educação especial, tendo realizado a oferta de atendimento educacional especializado nos anos seguintes à Constituição de 1988, seguindo as normativas impostas no artigo 208, parágrafo III “atendimento educacional especializado aos portadores de deficiência, preferencialmente na rede regular de ensino" (BRASIL, 1988) no contexto da municipalização da educação.

Importante ressaltar que em 1994, a Secretaria de Educação Especial (SEESP/MEC) recomenda que os municípios passem a se responsabilizar pelo atendimento educacional das pessoas com deficiência, por meio da elaboração do documento denominado "Expansão e Melhoria da Educação Especial nos Municípios Brasileiros". Padilha (2014) aponta que a criação do documento foi influenciada pelo Plano Decenal de Educação (1993-2003) e buscava mostrar que em grande parte dos municípios brasileiros, o atendimento educacional voltado às pessoas com deficiência era precário em termos de quantidade e qualidade. Dessa forma, através do referido documento, o governo sugere aos administradores municipais a realização de parcerias junto ao MEC com o objetivo de expandir a Educação Especial.

Porém, Padilha (2014) afirma que não foram garantidas as condições necessárias para que isso acontecesse devido à ausência de metas, mecanismos de financiamento, programas de formação de recursos humanos, diretrizes para a adequação física, entre outros aspectos, existindo apenas a orientação em relação à efetivação de alianças e parcerias entre os órgãos governamentais e cumprimento 
das disposições legais quanto aos dispositivos orçamentários em vigor. Assim, a responsabilidade de escolarização das pessoas com deficiência nos municípios ocorre nesse contexto.

Em 2001 o Ministério da Educação lançou as Diretrizes Nacionais para a Educação Especial na Educação Básica através da Resolução n 02/2001. Lobo (2011) afirma que em Corumbá o processo de inclusão foi respaldado nessas diretrizes a partir da previsão de um setor de Educação Especial para dar apoio à inclusão educacional de alunos com deficiência.

No ano de 2003 o Conselho Municipal de Educação (CME) publicou a Deliberação $n^{\circ}$ 74/2003, que estabeleceu a Política Municipal de Educação Especial na Educação Básica. O serviço voltado ao atendimento educacional dos alunos com deficiência ficou vinculado ao Centro de Atendimento Integral à Criança (CAIC) e em outras unidades escolares do Sistema Municipal de Ensino. Para o cumprimento da referida deliberação, foram previstas, dentre outras ações, articulação com os demais serviços públicos como: educação, saúde, trabalho, assistência social, outras agências municipais, estaduais e federais incumbidas da promoção do bem-estar social (RODRIGUES, 2017).

O objetivo do referido documento era constituir e fazer funcionar um setor responsável pela Educação Especial, com recursos humanos, materiais e financeiros que viabilizassem e dessem sustentação à construção da Educação Inclusiva. Cabia ao sistema municipal, através do referido setor, assegurar matrícula para todos, cabendo às escolas viabilizar as condições necessárias a uma educação de qualidade, considerando a organização curricular, através de adaptações necessárias dos recursos educativos, humanos e estrutura física adequada às necessidades específicas (CORUMBÁ, 2003). Importante salientar que a proposta visava o atendimento nas salas de recursos de alunos tanto da rede municipal, quanto de outras escolas ou ainda daqueles que não estivessem frequentando unidades escolares, mas necessitassem de atendimento específico (RODRIGUES, 2017).

Ainda em 2003, com o objetivo de criar um setor específico para os atendimentos voltados aos alunos público-alvo da educação especial, profissionais da Secretaria Municipal de Educação e da Universidade Federal de Mato Grosso 
do Sul, Campus do Pantanal propuseram um projeto que tinha como objetivo principal a oferta de serviços de responsabilidade compartilhada entre a Educação, Saúde, Trabalho e Assistência Social. A proposta também tinha por objetivo atender as orientações da Resolução CNE/CEB nº 2/2001 que estabelece que os sistemas de ensino devem ter um setor responsável pela educação especial (BRASIL, 2001).

No ano de 2004 o município oficializa o setor responsável pela educação especial através do Decreto $n^{\circ}$ 128/2004, criando a Unidade de Apoio à Inclusão de Portadores de Necessidades Especiais na Rede Municipal de Ensino com o objetivo de desenvolver a política de inclusão no sistema regular de ensino e também cria o Centro Multiprofissional de Apoio ao Desenvolvimento InfantoJuvenil (CMADIJ) para dar suporte aos alunos com deficiência matriculados nas redes municipal, estadual e particular da região (LOBO, 2011).

O CMADIJ tem como objetivo principal dar sustentação à política de Educação Inclusiva e garantir a oferta dos serviços de atendimento especializado na área da saúde e apoio pedagógico aos alunos com necessidades especiais temporárias ou permanentes, conforme a Resolução SEED n.023/2007, tal resolução baseia-se na Resolução CNE/CEB nº 2/2001. A Resolução SEED n.023 define como alunos com necessidades educacionais especiais aqueles que possuem dificuldades acentuadas de aprendizagem ou limitações no processo de desenvolvimento que dificultem o acompanhamento das atividades curriculares. As dificuldades podem ter ou não causa orgânica específica ou estarem vinculadas a disfunções, limitações ou deficiências. Os alunos com altas habilidades/superdotação também são considerados público alvo do referido centro. A normativa traz como objetivo, conforme apresentado no capítulo II, a sustentação das políticas da educação inclusiva. Cabe ressaltar, no entanto, que o parágrafo único do artigo $5^{\circ}$ utiliza a nomenclatura de alunos com necessidades educacionais especiais como sinônimo para alunos da educação especial: “A Educação Especial deve assegurar ao aluno com necessidades educacionais especiais, a formação comum indispensável e fornecer-lhe os meios de desenvolver atividades produtivas para progredir no trabalho e em estudos posteriores" (CORUMBÁ, 2007). 
O serviço oferecido pelo CMADIJ contava com a articulação entre educação, saúde e assistência social, com profissionais (neurologia pediátrica, fisioterapeutas, fonoaudiólogos, odontólogo, psicólogos e pedagogos) cedidos destas três secretarias que realizavam o trabalho de maneira permanente no centro. Tal situação possibilitava que a avaliação dos estudantes fosse realizada pelo serviço público, uma vez que anteriormente os atendimentos eram realizados apenas pela instituição privada de caráter filantrópico (Kassar, et al, 2018).

Dentre as competências do CMADIJ enfatizamos: a integração dos serviços especializados nas áreas de educação, saúde e assistência social; avaliação dos alunos com suspeita de deficiência; encaminhamento dos alunos avaliados, se necessário, aos serviços de educação especial; acompanhamento dos alunos com necessidades educacionais especiais na escola comum; promoção de momentos de discussão e reflexão, estudos de caso, entre outros, em conjunto com a coordenação pedagógica das escolas da rede municipal; implementar a formação em serviço; promoção de estudos nas unidades escolares com professores e coordenadores sobre as adaptações curriculares (Corumbá, 2007).

O crescimento das ações de caráter municipal e, sobretudo, nacional impulsionou a necessidade de formação continuada no campo da educação especial. Dessa maneira, no ano de 2003, Corumbá é escolhido como municípiopolo no Programa Educação Inclusiva: direito à diversidade. Em Mato Grosso do Sul, além de Corumbá, foram escolhidos os municípios de Campo Grande, Coxim, Dourados e Paranaíba. O polo de Corumbá abrangia os municípios de Antônio João, Aquidauana, Bandeirantes, Bodoquena, Bela Vista, Bonito, Caracol, Douradina, Guia Lopes da Laguna, Ladário, Miranda, Ponta Porã e Porto Murtinho (BRASIL, 2003).

A escolha dos municípios no referido programa, de acordo com o Projeto Plurianual de Educação Inclusiva nos Municípios (BRASIL, 2003), contou com aspectos ligados à localização geográfica, densidade demográfica, infraestrutura urbana e acessibilidade. Corumbá é a terceira cidade com maior número de habitantes no estado (IBGE, 2018) e está geograficamente distante das demais importantes cidades do Mato Grosso do Sul (428km de Campo Grande, 610km de 
Dourados e 753km de Três Lagoas). Tais fatores possuem grande influência para a escolha de Corumbá como município polo do referido programa.

Importante ressaltarmos que juntamente com os documentos referenciais desse programa, o Ministério da Educação orienta aos municípios a criação de Planos Municipais de Educação. O referencial denominado "O Município" (BRASIL, 2004) atenta para a importância dos planos municipais no campo da educação a partir da utilização de referenciais locais que podem ser usados como "norteadores para a definição de políticas públicas municipais" (p. 7). Mais adiante, apresentaremos brevemente o contexto de criação do primeiro Plano Municipal de Educação de Corumbá.

O Programa Educação Inclusiva: direito à diversidade, conforme já apresentado, teve por objetivo a disseminação da política de educação inclusiva nos municípios brasileiros e apoio à formação de gestores e educadores para efetivar a transformação dos sistemas educacionais em sistemas educacionais inclusivos. Em pesquisa realizada em Corumbá a respeito da formação ofertada pelo programa, Oliveira (2012) buscou verificar se os profissionais participantes desses cursos acreditam que os conhecimentos oferecidos influenciam sua metodologia de trabalho ${ }^{46}$. A partir dos resultados encontrados, a autora afirma que o fato do programa proporcionar apenas um encontro anual com duração de 40 horas, realizar as formações por meio de sucessão de palestras, não possuir mecanismos de acompanhamento dos cursos durante o ano, são fatores que limitam a efetividade do programa. Oliveira ressalta que essas formações não parecem ser suficientes diante da necessidade existente. A autora destaca também que tanto a formação do professor, quanto dos gestores, acaba acontecendo em grande parte, por iniciativa dos próprios profissionais, pois o poder público não oferta a formação continuada adequada para atender as demandas existentes dos alunos com deficiência matriculados e profissionais que atuam na rede municipal de educação.

\footnotetext{
${ }^{46}$ A pesquisa foi realizada em duas fases: a primeira contou com a aplicação de um questionário junto aos profissionais de educação (professores, intérpretes, coordenadores, técnicos escolares e psicólogos) que frequentaram os cursos realizados pelo programa no período de 2005 a 2009, totalizando 37 participantes. A segunda etapa constituiu-se de entrevistas com 20 profissionais de educação (participantes da primeira fase da pesquisa).
} 
Em 2007 é instituído o Programa de Implantação das Salas de Recursos Multifuncionais, no entanto, a rede municipal de Corumbá já possuía sala de recurso multifuncional desde o ano de 2005, inaugurada no contexto de implantação do Programa Educação Inclusiva: direito à diversidade (Kassar et al., 2018).

No contexto nacional, o Programa de Implantação de Salas de Recursos Multifuncionais (conforme apresentado no capítulo I), compôs o Plano de Desenvolvimento da Educação (PDE - 2007) e previu o apoio técnico e financeiro aos sistemas de ensino com vistas a garantir o acesso ao ensino regular e a oferta do AEE aos alunos com deficiência, transtornos globais do desenvolvimento e altas habilidades/superdotação (BRASIL, 2010). Os critérios para a escolha das escolas foram os seguintes: elaboração do Plano de Ações Articuladas (PAR) por parte da secretaria municipal; a escola indicada deve pertencer à rede pública de ensino regular; a escola deve possuir matrícula de alunos público-alvo da educação especial registrados no Censo Escolar (para implantação de sala tipo $\mathrm{I}^{47}$ ); a escola deve possuir matrícula de alunos cegos (para implantação de sala tipo II) e; a escola deve ter disponibilidade de espaço físico para o funcionamento da sala e atuação do professor no AEE (BRASIL, 2010). Todas as salas de recursos multifuncionais da rede municipal de ensino de Corumbá são do tipo I (SIMEC, 2019).

Em relação ao programa de implantação das salas de recursos multifuncionais, Pletsch (2011) afirma que diante da importância do suporte especializado oferecido para os alunos com necessidades educacionais especiais que frequentam a escola regular, deve-se frisar que a sala de recursos não pode ser

\footnotetext{
${ }^{47}$ As salas tipo I contam com os seguintes materiais: equipamentos - 2 microcomputadores, 1 laptop, 1 estabilizador, 1 scanner, 1 impressora laser, 1 teclado colmeia, 1 acionador de pressão, 1 mouse com entrada para acionador, 1 lupa eletrônica. Mobiliário - 1 mesa redonda, 1 mesa redonda, 4 cadeiras, 1 mesa para impressora, 1 armário, 1 quadro branco, 2 mesas para computador, 2 cadeiras. Materiais didáticos/pedagógicos -1 material dourado, 1 esquema corporal, 1 bandinha rítmica, 1 memória de numerais I, 1 tapete alfabético encaixado, 1 software comunicação alternativa, 1 sacolão criativo monta tudo, 1 quebra-cabeças - sequência lógica, 1 dominó de associação de ideias, 1 dominó de frases, 1 dominó de animais em Libras, 1 dominó de frutas em Libras, 1 dominó tátil, 1 alfabeto Braille, 1 kit de lupas manuais, 1 plano inclinado suporte para leitura, 1 memória tátil.

Já as salas tipo II (voltadas para os alunos com deficiência visual ou cegueira) contém os mesmos itens que as salas tipo I acrescido dos seguintes materiais: 1 impressora Braille - pequeno porte, 1 máquina de datilografia Braille, 1 reglete de mesa, 1 punção, 1 soroban, 1 guia de assinatura, 1 kit de desenho geométrico, 1 calculadora sonora.
} 
considerada a solução para todos os problemas e dificuldades enfrentados pela escola. A autora ressalta a necessidade da garantia aos professores do AEE e do ensino regular de formações que proporcionem conhecimentos para atuar com as especificidades do processo de ensino e aprendizagem dos alunos com deficiência. Outro ponto refere-se à importância de não confundir o atendimento especializado com reforço escolar e garantir que esses espaços não sejam reduzidos a meros espaços de acessibilidade temporária. O capítulo IV abordará a temática do atendimento educacional especializado e os profissionais que atuam nesses espaços no município de Corumbá.

Rebelo (2012) aponta que no ano de 2006, a rede municipal de educação contava com 137 alunos com deficiência matriculados no ensino regular e 141 matrículas na escola privada de caráter filantrópico, totalizando 278 matrículas. De acordo com a autora, nos anos seguintes ocorreu um pequeno aumento do número de matrículas na rede municipal de ensino, no entanto, não houve diminuição de matrículas na escola privada de caráter filantrópico.

$\mathrm{O}$ aumento das matrículas ocorreu nos anos iniciais do ensino fundamental (crescimento de 22,22\% entre os anos de 2007 e 2010). Esse aumento, segundo Rebelo (2012), demonstra o impacto positivo das políticas de inclusão escolar no crescimento do acesso desses alunos à educação. No entanto, esses resultados não se estendem à efetivação da permanência desse alunado na escola, pois os números de matrículas nos anos finais do ensino fundamental e no ensino médio são ínfimos em relação ao número de matrículas nos anos iniciais (Rebelo, 2012). O período de realização da pesquisa também demonstrou a manutenção dessa situação, uma vez que a maioria dos alunos com deficiência matriculados na rede municipal de ensino frequenta os anos iniciais do ensino fundamental, conforme os dados do Censo 2016.

Em 2008, as propostas nacionais ganham ainda mais força no âmbito municipal a partir do lançamento da Política Municipal de Educação Especial na Perspectiva da Educação Inclusiva que acompanha a Política Nacional da Educação Especial na Perspectiva da Educação Inclusiva (LOBO, 2011; RODRIGUES, 2017; KASSAR ET. AL., 2018). A política municipal prevê a diminuição de alunos por turma, para salas que possuem aluno com deficiência 
matriculado $^{48}$, salas de recursos multifuncionais, salas psicopedagógicas, intérprete de língua de sinais, transporte adaptado, dentre outras ações que englobam o atendimento específico às pessoas com deficiência.

Já em 2009 foi lançado o primeiro Plano Municipal de Educação de Corumbá, vigente até o ano de 2014 por meio da Lei Municipal n².091, de 18 de junho de 2009 ${ }^{49}$. Em 2015 o atual Plano Municipal de Educação (2015-2025) é publicado por meio da Lei Municipal 2.484/2015 de 26 de junho de 2015 em consonância com o Plano Nacional de Educação (Lei n 13.005/2014) e o Plano Estadual de Educação de Mato Grosso do Sul (PEE) (Lei Estadual n 4.621/2014). O Plano Municipal de Educação (2015 - 2025) apresenta objetivos e metas específicas em diversas áreas do campo da educação. Kassar et al. (2018) reiteram que a comparação das estratégias do PNE (2014) com o PME (2015) indica que Corumbá procura adequar suas metas ao contexto local ao se referir às suas características (escolas das águas, de fronteiras, indígenas e de comunidades quilombolas).

Os autores ressaltam também que o município não adota a estratégia do PNE que consiste em: "garantir a oferta de educação inclusiva, vedada a exclusão do ensino regular sob alegação de deficiência promovida a articulação pedagógica entre o ensino regular e o atendimento educacional especializado" (BRASIL, 2014). Os dados de matrículas mostram a constante procura pela instituição privada de caráter filantrópico ${ }^{50}$. A constância das matrículas na instituição

\footnotetext{
${ }^{48}$ A Deliberação n. 402/2015/CME/Corumbá-MS prevê que na sala de ensino regular em que houver inclusão de alunos com necessidades educacionais específicas, o quantitativo de alunos deverá ser, no máximo: I - Pré I - quinze crianças; Pré II - dezoito crianças. II - Ensino Fundamental: a) $1^{\mathrm{a}}$ série e $2^{\mathrm{a}}$ série - vinte alunos; b) $3^{\mathrm{a}}$ série a $5^{\mathrm{a}}$ série - vinte e cinco alunos; c) $6^{\mathrm{a}}$ série a $9^{\mathrm{a}}$ série - trinta alunos (CORUMBÁ, 2015).

${ }^{49} \mathrm{O}$ acompanhamento da execução do referido plano foi responsabilidade da "Comissão do Plano Municipal de Educação", juntamente com os técnicos da Secretaria Executiva de Educação e Conselho Municipal de Educação. O Plano Municipal de Educação (2009 - 2014) seguiu o padrão do Plano Nacional de Educação (2001 - 2011). No final de 2013, cerca de um ano antes do fim da vigência do Plano Municipal de Corumbá, o município participa do Fórum Estadual de Educação, realizado em Campo Grande (MS) com o objetivo de orientar os municípios sobre a metodologia de readequação dos Planos Municipais de Educação. A partir daí a Secretaria Municipal de Educação de Corumbá, o Conselho Municipal de Educação e o Fórum Municipal de Educação se reuniram para estruturar o processo de readequação do documento (Corumbá, 2015).

${ }^{50}$ Ao apresentar os dados da rede privada, que inclui a escola especializada de caráter assistencial, Kassar et al. (2018) mostram a constância no número de matrículas, que apresentava no ano de 2008 a quantidade de 147 alunos. Em 2012 o número de alunos na rede privada é de 159 e em 2017 são 141 matrículas.
} 
privada e a não adoção do PNE podem ser indicativos da força da instituição privada de caráter assistencial na política local (Kassar et al., 2018).

Em 2013 o CMADIJ passa por uma reestruturação. Rodrigues (2017) explica que o órgão, que anteriormente pertencia ao Núcleo de Inclusão Social, passa a pertencer ao Núcleo de Inclusão Escolar e Diversidade. No entanto a autora afirma que não foi possível encontrar o documento que oficializa a mudança do nome do núcleo e nesta pesquisa tampouco encontramos uma publicação a respeito no Diário Oficial de Corumbá (Diocorumbá ${ }^{51}$ ). O Núcleo de Inclusão Escolar e Diversidade é o atual responsável pela Educação Especial no município de Corumbá e conta com uma supervisora que é a responsável pela equipe de assessoras técnicas do CMADIJ. Portanto, em sua estrutura o núcleo conta com uma supervisora e o CMADIJ conta com sete assessoras técnicas. A estrutura atual do atendimento da educação especial em Corumbá se apresenta da seguinte forma:

\footnotetext{
${ }^{51}$ A única referência encontrada foi a nomeação da chefe do Núcleo de Inclusão e Diversidade com data de 22 de fevereiro de 2013. Anterior a essa data não foi encontrado nenhum documento que se refira ao Núcleo de Inclusão e Diversidade ou ao Núcleo de Inclusão Social.
} 
Figura 2: Organograma da Secretaria Municipal de Educação

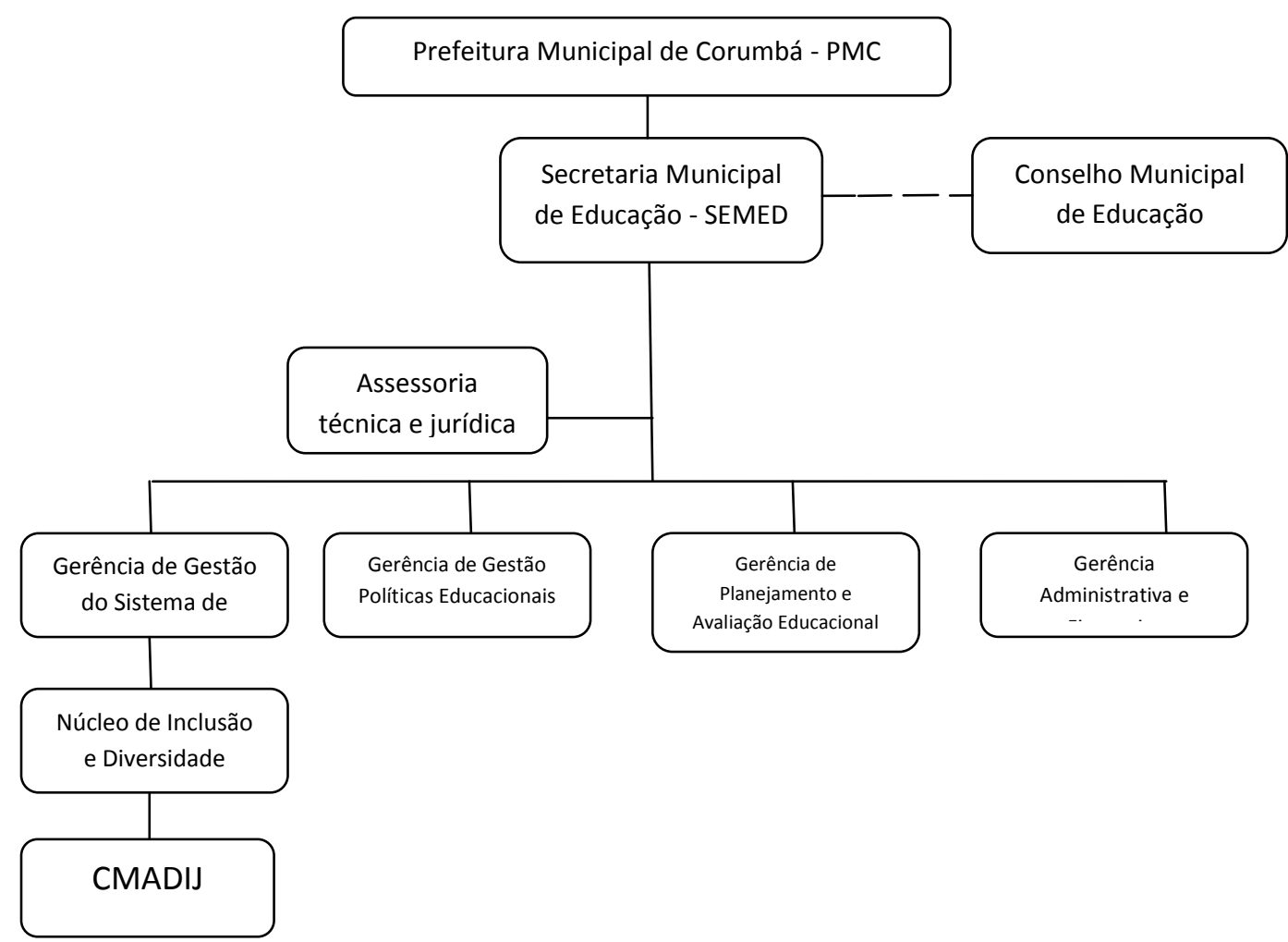

Fonte: Elaboração própria com base no Decreto № 1.141 de 28 de fevereiro de 2013 (Estrutura da Administração Direta Municipal de Corumbá).

A mudança ocorrida mantém a vinculação do CMADIJ com a Secretaria Municipal de Educação e com a Secretaria Executiva de Saúde Pública, no entanto, em outubro de 2012, os profissionais da área da saúde foram retirados e os serviços não foram mais oferecidos, com exceção do serviço odontológico. Os serviços educacionais, bem como as profissionais da área da educação foram mantidos (Rodrigues, 2017). Os estudantes, que anteriormente, contavam com os serviços de saúde vinculados à educação, passaram a ser encaminhados para outros locais (clínicas particulares ou públicas). Conforme a autora, a ausência dessa articulação pode prejudicar a integração dos atendimentos e, consequentemente, o desenvolvimento dos estudantes com deficiência.

A avaliação dos estudantes, realizada no próprio CMADIJ, também foi seriamente afetada após a mudança. Anteriormente, as unidades escolares encaminhavam os estudantes com suspeita de deficiência para avaliação no centro e, como o CMADIJ contava com uma equipe que integrava educação e saúde, a 
presença de um profissional médico dentro da equipe proporcionava a avaliação sem que o aluno precisasse ser encaminhado para outro serviço.

Em 2014 foi publicada a Portaria $n^{\circ}$. 1.027 SAS/MS, que implanta os Centros Especializados de Reabilitação $(\mathrm{CER})^{52}$. Esta implantação faz parte do Plano Nacional dos Direitos da Pessoa com Deficiência - Viver sem Limites e iniciou seus trabalhos com a implantação de 45 novos centros em todo o Brasil. O plano realiza ações de qualificação dos serviços e compõe a Rede de Cuidados à Saúde da Pessoa com Deficiência (Portaria MS/GM n 793, de 24 de abril de 2012) juntamente com a Rede SUS (Sistema Único de Saúde) de urgência e emergência (BRASIL, 2013).

No município de Corumbá, a implantação do CER ocorreu em uma instituição privada de caráter assistencial, no ano de 2015, por meio de um Termo de Contratualização da instituição privada com a prefeitura municipal. A parceria garante o repasse financeiro para viabilizar e aprimorar o atendimento ambulatorial na atenção especializada à saúde, às pessoas com deficiência física e intelectual, incluindo cuidados com pessoas ostomizadas ${ }^{53}$. A partir da adesão, a instituição especializada de caráter assistencial passou a receber mensalmente a importância de R \$140 mil reais, para aplicação na atenção à saúde para pessoas com deficiência temporária ou permanente; progressiva, regressiva ou estável; intermitente ou contínua, no âmbito do Sistema Único de Saúde. O repasse é realizado pelo próprio município (CORUMBÁ, 2015a).

A situação de Corumbá corrobora com a situação da educação especial no âmbito nacional, que possui em sua construção a figura constante de instituições especializadas privadas de caráter filantrópico que utilizam-se de recursos públicos para garantir seu funcionamento. Kassar et al. (2018) ressaltam que, mesmo diante da recomendação de parcerias (presente na política nacional e nos documentos dos organismos internacionais), estas se referem à

\footnotetext{
52 O CER é um ponto de atenção ambulatorial especializada em reabilitação que realiza diagnóstico, avaliação, orientação, estimulação precoce e atendimento especializado em reabilitação, concessão, adaptação e manutenção de tecnologia assistiva, constituindo-se em referência para a rede de atenção à saúde no território (BRASIL, 2017a).

53 Pessoas que passaram por uma intervenção cirúrgica para fazer no corpo uma abertura ou caminho alternativo de comunicação com o meio exterior, para saída de fezes ou urina, assim como auxiliar na respiração ou na alimentação. Essa abertura chama-se estoma (BRASIL, 2009a).
} 
complementaridade da "escolarização nas classes comuns, na formação de professores especializados ou no fornecimento de pessoal de apoio para atendimento especializado" (p. 307). Em Corumbá a parceria estabelecida com a instituição privada de caráter filantrópico extrapola essas recomendações, uma vez que o encolhimento das ações do CMADIJ e a transferência dos atendimentos da saúde para o poder privado apontam para um protagonismo da instituição privada de caráter filantrópico no município, como porta-voz da Educação Especial (ibidem).

Em 2017 o município publicou a Resolução SEMED nº 082 de 27 de dezembro de 2017 que dispõe sobre a organização curricular da Educação Básica do Município para o ano de 2018. A resolução traz em seu Título IV o item referente à "Educação Especial na Perspectiva Inclusiva", que afirma que:

[...] as Unidades Escolares e os Centros Municipais de Educação Infantil devem oportunizar aos estudantes com deficiência, transtornos globais do desenvolvimento e altas habilidades ou superdotação a inclusão em sala comum, promovendo condições de acesso, permanência, participação e aprendizagem, e serviços de apoio especializados de acordo com as necessidades individuais dos estudantes, por meio da flexibilização curricular e metodologia de ensino diferenciada, recursos de acessibilidade e pedagógicos adequados, processo de avaliação qualitativa, contínua e sistemática (CORUMBÁ, 2017 p.8).

A resolução também garante o atendimento educacional em ambiente hospitalar ou domiciliar, reforça a oferta do Atendimento Educacional Especial (AEE) disponibilizado nas Salas de Recursos Multifuncionais e ressalta que o AEE deve ser ofertado no contraturno das atividades escolares, tendo garantida a dupla matrícula. Assim, durante o ano de 2018, o Atendimento Educacional Especializado ofertado nas Salas de Recursos Multifuncionais se mantém como o principal programa voltado ao atendimento de alunos com deficiência matriculados na rede municipal.

A respeito das salas de recursos multifuncionais, a rede municipal de ensino é a dependência administrativa com maior quantidade de salas deste tipo. Das 16 existentes, 9 pertencem à rede municipal, enquanto a rede estadual conta com 7 salas. (SIMEC, 2019).

Kassar et al. (2018) afirmam que as salas de recursos multifuncionais existentes na cidade de Corumbá parecem não ser suficientes para atender toda a população da educação especial. Os autores utilizam dados do INEP (2017) para 
mostrar que de 2009 para 2017 ocorreu um aumento significativo do número de alunos matriculados na rede municipal, porém não houve aumento do atendimento educacional especializado. A porcentagem dos alunos com deficiências, matriculados na educação básica, que recebiam atendimento em sala de recursos que era de 80,37\% no ano de 2009 diminuiu para 23,98\% em 2017.

Ainda no final do ano de 2017, a Secretaria Municipal de Educação publica a Instrução Normativa n ${ }^{\circ} 001 / 2017$ que dispõe sobre as orientações quanto ao funcionamento da Educação Especial para o ano de 2018 em Corumbá. A normativa organiza os atendimentos e as atribuições do Núcleo de Inclusão Escolar e Diversidade ${ }^{54}$, CMADIJ, Salas de Recursos Multifuncionais, Intérprete de Libras, Profissional de Apoio e Atendimento Hospitalar e Domiciliar. Daremos ênfase às atribuições do Núcleo de Inclusão Escolar e Diversidade, dos profissionais de apoio e os que atuam nas salas de recursos multifuncionais, pois foram profissionais que participaram da presente pesquisa.

A instrução normativa afirma que o Núcleo de Inclusão Escolar e Diversidade possui como objetivo garantir o acesso, participação e aprendizagem dos alunos com deficiência, divulgando e implementando a Política de Educação Especial; deve atuar em interface com a Secretaria de Saúde e Secretaria de Assistência Social, para viabilizar o atendimento especializado aos alunos; acompanhar o atendimento nas salas de recursos multifuncionais; promover a formação em serviço aos profissionais das salas de recursos multifuncionais; dinamizar ações, programas e projetos para a educação inclusiva e inclusão social; elaborar e manter atualizado banco de dados sobre alunos e professores da Educação Especial (CORUMBÁ, 2017).

A partir das atribuições do núcleo, percebemos a amplitude das ações realizadas. Nesse sentido é importante destacar que o núcleo possui apenas um centro ligado a ele (o CMADIJ) e que todas essas atribuições concentradas nesse setor estão sob a responsabilidade de 7 profissionais, sendo uma supervisora e 6 assessoras técnicas. As profissionais são, em sua maioria, pedagogas, à exceção

\footnotetext{
${ }^{54}$ No referido documento o núcleo aparece com o nome de Núcleo dos Programas de Inclusão Escolar e Diversidade. No texto optamos por manter o nome de Núcleo de Inclusão Escolar e Diversidade, utilizado em todos os outros documentos e também chamado assim pelos participantes da pesquisa.
} 
de uma psicóloga que possui especialização em Psicopedagogia (o que garante sua permanência no núcleo). As assessoras técnicas estão ligadas ao CMADIJ, sob a chefia da supervisora responsável pelo Núcleo de Inclusão Escolar e Diversidade. A atual supervisora informa que o núcleo, até o ano de 2017, contava com uma coordenação, porém, após a aposentadoria da coordenadora, não houve substituição e o núcleo passou a contar apenas com a supervisão e as assessorias técnicas.

Retornando à instrução normativa que orienta os atendimentos voltados aos alunos com deficiência, temos as salas de recursos multifuncionais. De acordo com a instrução, o atendimento realizado deve considerar a natureza geral da deficiência, na qual o professor deve atender todas as necessidades do aluno encaminhado, sejam complementações ou suplementações curriculares. A instrução prevê também a forma como o aluno será encaminhado para frequentar a sala, o tempo do atendimento, a maneira como o atendimento será realizado (se individual ou em grupo), o funcionamento diário da sala e os resultados das reuniões entre os professores do atendimento educacional especializado e do ensino regular (Corumbá, 2017).

Quanto às atribuições do professor do atendimento educacional especializado, a normativa prevê como funções:

I - Acompanhar o processo de inclusão dos alunos na escola comum;

II - Atuar, como docente, nas atividades de complementação ou suplementação curricular específica que constituem o atendimento educacional especializado dos alunos da Educação Especial;

III - Atuar de forma colaborativa com o professor da sala de Ensino Regular para a definição de estratégias pedagógicas que favoreçam o acesso do aluno ao currículo e a sua interação no grupo;

IV - Promover as condições para a inclusão dos alunos com deficiência em todas as atividades da escola;

V - Orientar as famílias para o seu desenvolvimento e a sua participação no processo educacional;

VI - Informar a comunidade escolar acerca da legislação e normas educacionais vigentes que asseguram a inclusão educacional;

VII - Participar do processo de identificação e tomada de decisões acerca do atendimento às deficiências dos alunos;

VIII - Preparar material específico para uso dos alunos na sala de recursos;

IX - Orientar a elaboração de materiais didático-pedagógicos que possam ser utilizados pelos alunos nas salas de ensino regular;

$\mathrm{X}$ - Indicar e orientar o uso de equipamentos e materiais específicos e de outros recursos existentes na família e na comunidade;

XI - Articular com gestores e professores, para que o projeto pedagógico da instituição de ensino se organize coletivamente numa perspectiva de educação inclusiva;

XII - Participar das reuniões técnico-pedagógicas, do planejamento, dos conselhos de classe, da elaboração do projeto pedagógico, desenvolvendo ação conjunta com os 
professores da sala de ensino regular e demais profissionais da escola para a promoção da inclusão escolar (CORUMBÁ, 2017).

Importante ressaltarmos que as legislações de âmbito nacional que normatizam o atendimento educacional especializado classificam-no como um atendimento complementar destinado ao aluno com deficiência e/ou transtornos globais do desenvolvimento, de acordo com a Política Nacional de Educação Especial na Perspectiva da Educação Inclusiva (BRASIL, 2008, grifo nosso). A orientação normativa da rede municipal de Corumbá apresenta alguns objetivos que possuem maior amplitude quanto ao objetivo do atendimento como algo complementar, dentre eles destacamos: promover as condições para a inclusão dos alunos em todas as atividades da escola; orientar as famílias para o seu desenvolvimento e a sua participação no processo educacional; informar a comunidade escolar acerca da legislação e normas educacionais vigentes que asseguram a inclusão educacional (CORUMBÁ, 2017 grifo nosso). Os itens elencados podem ser considerados de responsabilidade de toda a comunidade escolar e não entendidos como uma atribuição apenas do professor do atendimento educacional especializado.

Já a respeito dos profissionais de apoio, percebemos que o documento também apresenta orientações genéricas, tal como: promover a permanência e o sucesso do aluno com deficiência na escola, efetivando os princípios da inclusão educacional; (CORUMBÁ, 2017 grifo nosso). Tal orientação possui grande amplitude, uma vez que promover a permanência do aluno com deficiência na escola não deveria estar vinculada à atuação de um único profissional, sendo essa não apenas uma orientação voltada a um único profissional, mas sim de todo o projeto político pedagógico da escola.

A Nota técnica $n^{\circ} 24 / 2013$ do Ministério da Educação ${ }^{55}$ estabelece que o serviço do profissional de apoio deva ser disponibilizado sempre que identificada a necessidade individual do estudante a fim de garantir a acessibilidade da comunicação e atenção aos cuidados pessoais de alimentação, higiene e locomoção (BRASIL, 2013b). Tal legislação segue as diretrizes da Convenção

\footnotetext{
${ }^{55}$ Orienta os sistemas de ensino para a implementação da Lei $n^{\circ} 12.764 / 2012$ que institui a Política Nacional de Proteção dos Direitos da Pessoa com Transtorno do Espectro Autista, atendendo a Política Nacional da Educação Especial na Perspectiva da Educação Inclusiva.
} 
sobre os Direitos da Pessoa com Deficiência (CDPD - 2006). De acordo com a CDPD não é atribuição do profissional de apoio desenvolver atividades educacionais diferenciadas, nem se responsabilizar pelo ensino deste aluno. Sua atuação não deve substituir o professor regente, professor do AEE e nenhum outro profissional da escola, em nenhuma atividade ou responsabilidade. $\mathrm{O}$ profissional de apoio, após orientação e entrega do material pedagógico por parte do professor(a), deve auxiliar o estudante no cumprimento das atividades.

O profissional de apoio é destinado aos alunos que não realizam atividade de alimentação, higiene, comunicação ou locomoção com autonomia e independência; sua atuação ocorre apenas nos casos em que a necessidade específica do estudante não for atendida no contexto geral dos cuidados disponibilizados aos demais estudantes. A necessidade de sua permanência deve ser avaliada periodicamente pela escola, juntamente com a família (BRASIL, 2013b).

Portanto, os documentos apontam para um aumento das atribuições desses profissionais no âmbito municipal, uma vez que suas atribuições apresentam amplitude em relação às normativas apresentadas pelos documentos nacionais, atribuindo a esses profissionais maiores responsabilidades.

A atuação desses profissionais e dos professores regentes será melhor explorada no capítulo IV, onde serão discutidos os resultados da primeira e segunda fase da pesquisa.

\section{3. \\ Os fenômenos que emergem dos discursos: uma análise inspirada na perspectiva hermenêutico-dialética.}

A pesquisa de campo foi realizada em dois momentos. $\mathrm{O}$ primeiro referese à aplicação do survey, utilizado com o objetivo de conhecermos inicialmente os profissionais da educação que atuam nas escolas urbanas daa rede municipal de ensino. No segundo movimento de pesquisa empírica foram realizadas 
observações e entrevistas em três unidades escolares escolhidas para o aprofundamento do estudo ${ }^{56}$.

As entrevistas foram semi-estruturadas a partir de um roteiro único que foi utilizado como ponto de partida para a conversa. A escolha da entrevista semiestruturada se deu devido à possibilidade de abordar todos os temas de interesse da pesquisadora. Minayo (2008) afirma que a entrevita semi-estruturada facilita a abordagem e assegura que as hipóteses ou pressupostos sejam cobertos na conversa.

O roteiro incluía questões sobre a trajetória e formação profissional, atribuições, relações com os membros da equipe de trabalho, percepções a respeito da escola ser ou não inclusiva, identificação e encaminhamento de alunos com deficiencia. Importante ressaltar que, o ritmo dos diálogos sofreu por vezes influências externas, como tempo do intervalo do professor regente, entrevistas realizadas em locais de grande circulação de pessoas, devido à ausência de um local reservado ou por serem realizadas durante uma aula de educação física (caso dos profissionais de apoio, que em sua maioria, não possuem hora-atividade). Porém, a maioria das entrevistas não sofreram intercorrências e os entrevistados mostraram-se bastante interessados em participar.

Em algumas entrevistas foi possível perceber que o momento propiciou a reflexão acerca da atuação do participante. Durante uma das entrevistas, a agente agradece a oportunidade de participação e ressalta que a entrevista a fez pensar em sua atuação. Afirma que foi um momento em que ela finalmente conseguiu parar para realizar uma espécie de auto avaliação.

Nesse sentido, Minayo (2008) afirma que durante a entrevista, o participante fornece informações advindas da reflexão sobre si mesmo sobre a realidade vivenciada. As informações constituem uma representação da realidade: ideias, crenças, maneira de pensar, opiniões, sentimentos, maneiras de sentir, de atuar, condutas, projeções para o futuro, razões conscientes ou inconscientes, dentre outros aspectos. Assim, as falas dos atores sociais foram situadas no contexto para possibilitar sua melhor compreensão. Tomando como ponto de

\footnotetext{
${ }^{56}$ As informações referentes à aplicação do survey e entrevistas realizadas serão abordadas no capítulo IV, bem como, os critérios para a escolha das três unidades escolares pesquisadas.
} 
partida o interior da fala e ponto de chegada o campo da especificidade histórica e totalizante que produz a fala (GOMES, 2002 p.77 grifos do autor).

As observações sobre o cotidiano escolar foram realizadas, em média, durante cerca de um mês por unidade escolar. Inicialmente foi realizado o contato com as três escolas, que já haviam participado da primeira fase da pesquisa (survey). A partir daí solicitamos a autorização para a realização das observações. Em todas as unidades uma das coordenações auxiliou a entrada nas salas de aula e no contato com os professores. Os locais observados foram salas de aula, sala dos professores, sala da equipe de gestão e espaços comuns como pátios, refeitórios e entrada ${ }^{57}$ dos alunos.

O critério para escolha das salas de aula para observação era possuírem, ao menos, um aluno com deficiência. Desse modo, ao chegar na unidade, era solicitado à coordenação a autorização para a entrada na sala. A partir daí, era escolhida a sala que seria acompanhada e feita a solicitação de entrada ao professor. Todos os professores foram solícitos e em alguns casos, foi possível perceber que eles desejavam mostrar seu trabalho, principalmente as dificuldades existentes. Alguns pediram que a observação fosse realizada mais de uma vez.

Nessas situações, buscamos conversar com os profissionais para entender melhor suas necessidades, dando espaço de escuta para que eles pudessem colocar seus anseios. A esse respeito, Minayo (2008) ao falar sobre a observação participante, ressalta a necessidade do pesquisador relativizar o seu espaço social, aprendendo a se colocar no lugar do outro, principalmente devido à proximidade com os interlocutores.

Devido à atuação da pesquisadora em locais de atendimento de alunos com deficiência (escola especializada e coordenação de um núcleo responsável pelo apoio de alunos com necessidades educacionais especiais em uma instituição de ensino federal) a maioria dos participantes conhecia a pesquisadora. Esse fator foi positivo, pois possibilitou a abertura de portas em diversos locais, bem como a facilidade de contato com alguns atores importantes no que se refere à implementação das políticas da educação especial. Em contrapartida, esse fator

\footnotetext{
${ }^{57}$ Os alunos, geralmente do Ensino Fundamental I, durante a entrada, conhecida na rede como acolhida, é realizada uma fila e os alunos fazem uma oração, recebem informes e vão para as salas, em fila, acompanhados pelos professores.
} 
pode ter afetado também a maneira como os participantes apresentaram sua realidade para a pesquisadora. Por esse motivo é importante que sejam analisados vários aspectos, considerando pontos de vista distintos sobre um mesmo fenômeno e o possível viés imposto por esta condição.

As pessoas que introduzem o pesquisador no campo são responsáveis pela sua primeira imagem, além de serem importantes também no que se refere às oportunidades encontradas durante o trabalho de campo. O perfil dos informantes e a qualidade dos dados recolhidos possuem relação com o impacto da entrada e da apresentação do pesquisador. Diante da situação particular da pesquisa, o que está em jogo é a capacidade de empatia, observação e aceitação do pesquisador que não pode ser transformada em receituário prático. As pessoas que o introduzem no campo, preocupam-se sobretudo, com a personalidade e o comportamento do pesquisador, uma vez que esses aspectos serão cruciais para que exista uma relação de confiança. Para os participantes importa saber se o pesquisador "é uma boa pessoa" e se não vai "fazer mal ao grupo", não vai "trair seus segredos" e suas estratégias de resolver os problemas (Minayo, 2008, grifos da autora).

Nesse sentido, o conhecimento prévio a respeito do trabalho desenvolvido pela pesquisadora, por parte de alguns participantes, foi importante para que algumas informações fossem acessadas. Frases como "vou te contar isso, porque já te conheço" e "a gente fala isso pra você, porque você está pesquisando, não falaríamos isso para outras pessoas" são alguns exemplos de situações em que a pesquisadora teve acesso a algumas informações que, talvez não fossem expostas em outros momentos ou para outras pessoas que não possuíssem tais características. Nessas situações, foi deixado bem claro que a identidade dos participantes da pesquisa não seria revelada, tampouco as escolas teriam seus nomes divulgados.

A esse respeito, Bourdieu (2008) afirma que a proximidade social e a familiaridade entre pesquisador e pesquisados asseguram duas condições principais de uma comunicação "não violenta" ${ }^{58 "}$ :

\footnotetext{
${ }^{58}$ Relação de escuta ativa e metódica, tão afastada da pura não-intervenção da entrevista não dirigida, quanto do dirigismo do questionário. Postura de aparência contraditória que não é fácil de
} 
De um lado, quando o interrogador está socialmente muito próximo daquele que ele interroga, ele lhe dá, por sua permutabilidade com ele, garantias contra a ameaça de ver suas razões subjetivas reduzidas a causas objetivas; suas escolhas vividas como livres, reduzidas aos determinismos objetivos revelados pela análise. Por outro lado, encontra-se também assegurado neste caso um acordo imediato e continuamente confirmado sobre os pressupostos concernentes aos conteúdos e às formas da comunicação (p. 697).

A inserção da pesquisadora no campo também apresenta aspectos pessoais e profissionais que influenciam sua atuação, principalmente devido às experiências de trabalho com alunos com deficiência. Por vezes, ocorreu certa dificuldade em manter-se em total posição de escuta durante as entrevistas, ocasionando algumas intervenções que podem ter conduzido falas. No entanto, a triangulação ${ }^{59}$ das informações coletadas possibilitou que um mesmo fenômeno fosse analisado a partir de dados coletados em situações diversificadas. Outro fator importante nessa relação foi a realização de entrevista com distintos atores (professores regentes, profissionais de apoio, professores do AEE, gestores, representantes da secretaria de educação) contribuindo para que os diversos olhares e opiniões fossem considerados e analisados.

Quanto à situação de inserção da pesquisadora no campo considerando suas experiencias anteriores, Minayo (2008) afirma que:

É bom lembrar mais uma vez que no campo, assim como durante todas as etapas da pesquisa, tudo merece ser entendido como fenômeno social e historicamente condicionado: o objeto investigado, o pesquisador e seu sistema de representações teórico-ideológicas, as técnicas de pesquisa e todo o conjunto de relações interpessoais e de comunicação simbólica (p.297).

As contribuições de Valle e Connor (2014) também foram importantes nas análises. Os autores referem-se ao "mito da homogeneidade", que orienta a busca de novos métodos para se classificar as crianças de acordo com as suas semelhanças. Eles afirmam que, "talvez o problema esteja em nossas expectativas" (p.72). Ademais, a conceituação de normal/anormal da educação

se colocar em prática. Efetivamente, ela associa a disponibilidade total em relação à pessoa interrogada, a submissão à singularidade de sua história particular, que pode conduzir, por uma espécie de mimetismo mais ou menos controlado, a adotar sua linguagem e a entrar em seus pontos de vistas, em seus sentimentos, em seus pensamentos, com a construção metódica, forte, do conhecimento das condições objetivas, comuns a toda uma categoria (BOURDIEU, 2008 p. 695).

\footnotetext{
${ }^{59}$ A triangulação consiste na combinação e no cruzamento de múltiplos pontos de vista, integrando a visão de vários informantes e empregando uma variedade de técnicas de coleta de dados que acompanha a pesquisa (MINAYO, 2005).
} 
especial influencia os professores a enxergarem os alunos como "adequados" ou "não adequados" (grifos dos autores). A relação de adequação/não adequação apresentada pelos autores dialoga com a premissa de Maynard-Moody e Musheno sobre a discricionariedade dos agentes do cidadão e os merecedores e não merecedores dos serviços públicos.

A partir do trabalho de campo foram estabelecidas as categorias de análises que serão apresentadas nos capítulos seguintes, sendo elas: a atuação dos agentes implementadores no âmbito da Secretaria Municipal de Educação, suas percepções e relações com as diferentes hierarquias que integram a política de educação especial no município. E a atuação dos agentes implementadores presentes nas unidades escolares, sendo eles os diretores, coordenadores e os professores regentes, professores do AEE e profissionais de apoio. A interação entre esses atores e suas relações com os alunos e famílias nos mostraram importantes aspectos da implementação da política educacional voltada às pessoas com deficiência em Corumbá/MS. Os agentes implementadores no âmbito da secretaria e das escolas (com exceção dos professores regentes, do AEE e profissionais de apoio) constituem-se como agentes híbridos, pois atuam hora como BMEs, hora como BNR, a depender do público que se relacionam (Mota, 2018), conforme apresentamos nos próximos capítulos. 


\section{3 \\ A POLÍTICA DE EDUCAÇÃO ESPECIAL NA PERSPECTIVA DA EDUCAÇÃO INCLUSIVA EM CORUMBÁ: perspectivas dos agentes implementadores da Secretaria Municipal de Educação}

O presente capítulo tem como objetivo apresentar a discussão acerca dos atores que participam da implementação das políticas públicas educacionais voltadas às pessoas com deficiência na rede municipal de Corumbá, no âmbito da Secretaria Municipal de Educação. Participaram das entrevistas individuais: duas supervisoras do Núcleo de Inclusão Escolar e Diversidade (uma que respondia pelo núcleo no ano de $2016^{60}$ e outra responsável pelo núcleo de $2018^{61}$ até o presente momento) e a coordenadora do CMADIJ (entrevista concedida em 2016). Foi realizada também uma entrevista de maneira coletiva com três assessoras técnicas ${ }^{62}$ do CMADIJ no ano de 2018, totalizando a participação de seis agentes da Secretaria Municipal de Educação na segunda fase da pesquisa.

Quanto à trajetória profissional das entrevistadas, a Supervisora I possui formação em Pedagogia e atuou no núcleo no período de fevereiro 2013 a janeiro 2017. Já a Supervisora II também possui formação em Pedagogia e passou a responder pelo núcleo em janeiro de $2018^{63}$. Anteriormente, trabalhou por 13 anos na instituição privada de caráter filantrópico (de 2003 a 2015) inicialmente como professora, coordenadora e, por último, como diretora. Ela relata que a partir da sua aprovação no concurso da rede municipal de ensino foi encaminhada para uma escola da zona urbana e permaneceu lá apenas por apenas uma semana, sendo convidada para compor a equipe do CMADIJ como assessora técnica.

\footnotetext{
${ }^{60}$ A quem iremos nos referir como Supervisora I.

${ }^{61}$ A quem iremos nos referir como Supervisora II.

${ }^{62}$ Que nos referiremos como: Assessora técnica I, Assessora técnica II e Assessora técnica III, respectivamente.

${ }^{63}$ No período entre janeiro de 2017 a janeiro de 2018 houve outra supervisora respondendo pelo núcleo, no entanto, embora tenhamos feito contato $^{63}$, não realizamos entrevista. Foi realizada apenas uma conversa para apresentação do projeto de pesquisa e conhecimento da atuação do núcleo na rede por meio de visita à duas unidades escolares.
} 
Atuou como assessora de 2015 a 2017, assumindo a supervisão do núcleo em janeiro de 2018.

Em relação à coordenação, o CMADIJ contou com a profissional até o ano de 2018. Após esse período a então coordenadora se aposentou e sua vaga não foi preenchida. Atualmente o CMADIJ não conta com uma coordenação em sua equipe, possuindo como chefia imediata a supervisora responsável pelo Núcleo de Inclusão Escolar e Diversidade. A coordenadora possuía formação em Psicologia e atuou no centro do período de 2009 a 2018. Anteriormente a coordenadora trabalhou na instituição especializada de caráter filantrópico por aproximadamente 20 anos.

Das três assessoras técnicas do CMADIJ, duas possuem formação em Pedagogia e uma delas formação em Psicologia. A assessora técnica I (psicóloga que atua no núcleo como psicopedagoga) tem uma longa trajetória dentro da rede municipal, sendo uma das responsáveis pela implantação do centro. Atuou no CMADIJ durante sua implantação, saindo da rede municipal de ensino e retornando no ano 2013. No segundo semestre de 2013 ela passou a atuar na Secretaria de Assistência Social, permanecendo até o ano de 2016. Em 2016 ela volta para a rede municipal de ensino e atua como profissional de apoio. Seu retorno ao CMADIJ ocorre em julho de 2017 e permanece até o período da realização da pesquisa.

Já a assessora técnica II possui formação em Pedagogia e está na rede municipal há 26 anos. Atuou como professora do ensino regular por um ano e foi convidada para atuar nos atendimentos voltados aos alunos com deficiência auditiva, onde permaneceu do ano de 1996 até 2008. No ano de 2009 ela foi cedida para o município de Campo Grande/MS e atua no NAAHS (Núcleo de Atividades de Altas Habilidades/Superdotação), permanecendo lá por 4 anos. Em 2012 ela retorna para Corumbá e é convidada para trabalhar no CMADIJ, onde permanece até o momento de realização da pesquisa.

A assessora técnica III também possui formação em Pedagogia e está na rede municipal de ensino desde o ano de 2008 (nesse período como professora contratada e a partir de 2012, como efetiva). Inicialmente trabalhou como professora de educação infantil e no segundo semestre do ano de 2013 recebeu 
convite para atuar como profissional de apoio em uma creche. Permaneceu nessa atividade até o final do ano de 2013 e em 2014 passou a compor a equipe do CMADIJ.

A seguir, apresentaremos o contexto de criação do CMADIJ conforme o relato das entrevistadas que fizeram parte da história de sua implementação.

\section{1. \\ O contexto de criação do CMADIJ, formulação de políticas públicas e os burocratas de alto escalão: disputas em ação.}

O CMADIJ possui como objetivo dar sustentação à Política de Educação Inclusiva, no âmbito da rede municipal de ensino, conforme legislação apresentada no capítulo II. As mudanças descritas ocorridas no âmbito do CMADIJ ao longo do tempo, que contribuíram para a diminuição de sua equipe de trabalho, entre outros aspectos, têm profundas relações com as gestões superiores do município, incluídas a secretaria de educação e secretaria de saúde. Para entendermos essas relações, vamos analisar o contexto de criação do centro e sua trajetória posterior, conforme o relato coletado durante as entrevistas com as agentes que compõem o Núcleo de Inclusão Escolar e Diversidade e o CMADIJ.

As entrevistas com as técnicas do CMADIJ foram importantes para recuperar a história de sua fundação. A assessora técnica I relata que, no início dos anos 2000 foi chamada pela secretária municipal de educação (durante a gestão de Éder Moreira Brambilla $^{64}$ ) para implantar um centro voltado ao atendimento educacional de pessoas com deficiência. Ela relata que possuía um projeto com essa proposta desde o ano de 1997, porém, naquele momento não houve interesse na implantação. A entrevistada ressalta que o interesse ocorreu a partir da promulgação de leis que orientavam os municípios a criar um setor responsável pela educação especial. Nesse aspecto destacamos a Resolução $\mathrm{CNE} / \mathrm{CEB} \mathrm{n}^{\circ} 02 / 2001$, apresentada no capítulo I deste trabalho.

Dessa forma, a partir do ano de 2003, o Conselho Municipal de Educação do Município aprova o Parecer CME n³8 que garante a criação de um serviço especializado no Centro de Atendimento Integral à Criança (CAIC) e em outras

\footnotetext{
${ }^{64}$ Éder Moreira Brambilla (PSDB) foi prefeito de Corumbá no período de 1997-2000 e de 2001 a 2004.
} 
unidades escolares que pertencessem à rede municipal de ensino para atender a clientela da educação especial (Kassar, Oliveira e Silva, 2007). No ano de 2004 cria-se o CMADIJ com a estrutura que contava com a parceria entre as Secretarias Municipais de Saúde e Educação.

A coordenadora do CMADIJ também conta durante a entrevista, sobre a implantação do centro e afirma que o objetivo é dar suporte às políticas educacionais do município voltadas às pessoas com deficiência. Segundo ela, as atividades do centro foram iniciadas com uma equipe completa que contava com terapeuta ocupacional, odontólogo, fisioterapeuta, ortopedista, clínico geral, fisioterapeuta, neuropediatra, fonoaudiólogo, pedagogos e psicólogos na área escola e clínica. Ela ressalta que o centro realizava as avaliações dos alunos encaminhados pelas unidades escolares e dos alunos que necessitavam de atendimentos especializados passavam a frequentar o centro no período contraturno.

A coordenadora conta que essa estrutura foi se modificando no decorrer das mudanças de gestão do município. Segundo ela, no ano de $2013^{65}$ os profissionais lotados na Secretaria de Saúde que atuavam no CMADIJ foram retirados, restando apenas os profissionais da educação. A entrevistada reitera que a justificativa foi o fato de que o atendimento educacional especializado era de responsabilidade apenas da secretaria de educação.

Sobre essas questões, Capella (2007) traz em seus estudos as perspectivas teóricas do processo de formulação de políticas públicas, a partir de dois modelos desenvolvidos para explicar como as agendas governamentais são formuladas e alteradas: O Modelo de Múltiplos Fluxos (desenvolvido por John Kingdon 2003) e o Modelo de Equilíbrio Pontuado ${ }^{66}$ (de Frank Baumgartner e Brian Jones - 1993). Consideramos que o Modelo de Múltiplos Fluxos seja mais útil para a

\footnotetext{
${ }^{65}$ Durante o mandato de Paulo Duarte (2013-2016).

${ }^{66}$ Neste modelo os autores procuraram criar um mecanismo que permitisse a análise tanto de períodos de estabilidade, como aqueles em que ocorrem mudanças rápidas no processo de formulação de políticas públicas. Nesse modelo, longos períodos de estabilidade, em que as mudanças se processam de forma lenta, incremental e linear, são interrompidos por momentos de rápida mudança. Essa ideia é aplicada às agendas que mudam de forma rápida devido ao que os autores chamam de feedback positivo. Algumas questões ganham importância, atraindo outras, funcionando como um efeito em cascata. Quando isso ocorre, algumas ideias tornam-se populares, disseminam-se e ocupam o lugar de antigas propostas (CAPELLA, 2007).
} 
compreensão sobre o processo de formulação da política municipal de educação especial em Corumbá. Portanto, sob esta perspectiva pretendemos verificar como ocorreu a formulação da política, para então empreendermos as análises referentes à sua implementação, objeto da pesquisa desenvolvida.

O Modelo de Múltiplos Fluxos (Multiple Streams Model) preocupa-se com os estágios pré-decisórios da formulação de políticas. Uma questão passa a fazer parte da agenda quando desperta a atenção e o interesse dos formuladores de políticas. Porém, devido à complexidade e ao volume de questões existentes, apenas algumas delas são consideradas em um determinado momento. Estas compõem a 'agenda decisional' (Capella, 2007 grifos da autora).

Kingdon (2003), ao propor o modelo, descreve três importantes fluxos de convergência: problemas (problems), soluções ou alternativas (policies) e política (politics). A respeito dos problemas, os formuladores de políticas depositam sua atenção em determinadas situações de acordo com a forma como eles as percebem, interpretam. Questões são percebidas como problemas quando chamam a atenção dos atores em um processo decisório. Em relação às soluções ou alternativas, elas são definidas em um processo competitivo de seleção, que considera sua viabilidade técnica, o fato de representarem valores compartilhados e ainda a questão da visibilidade dos formuladores destas soluções ou alternativas. Finalmente, a fase final da formulação consiste na barganha ou negociação política da proposta (policy) a ser adotada. Essa fase depende do que Kingdon chama de "humor nacional" ${ }^{67}$,, das forças políticas organizadas (grupos de pressão) e das mudanças dentro do governo (CAPELLA, 2007).

A implantação do CMADIJ passou por alguns destes processos para se constituir como setor responsável pela materialização da política pública da educação especial no município de Corumbá. O papel dos atores do alto escalão (secretários e prefeito) foi fundamental e respondeu também às pressões do governo federal para a implementação do setor que deveria atender os alunos com necessidades educacionais especiais (Resolução CNE/CEB n. 02/2001). Outro fato que merece atenção foi o relato da coordenadora do centro, que enfatiza que

\footnotetext{
${ }^{67}$ Situação na qual diversas pessoas compartilham as mesmas questões durante um determinado período de tempo. Possibilita alto semelhante a um "solo fértil" para algumas ideias "germinarem" (CAPELLA, 2007).
} 
as mudanças posteriores (mais precisamente a de 2013) ocorreram devido a mudanças da alta gestão da secretaria de educação. Sobre isso, Capella (2007) ressalta a importância dos atores do alto escalão, que atuam conforme o clima nacional e as mudanças dentro do governo, sendo esses dois fatores "os maiores propulsores de transformações na agenda governamental" (p.95).

Assim, a mudança dos atores contribuiu para que o centro fosse implementado e também para a diminuição da equipe. A coordenadora do CMADIJ também conta um pouco como acontecem os atendimentos após a retirada dos profissionais da saúde. Essas mesmas questões aparecem também na entrevista realizada com a Supervisora I do Núcleo de Inclusão Escolar e Diversidade. Trata-se da relação com a instituição privada de caráter assistencial a partir do momento em que a equipe de saúde deixa de compor o CMADIJ. Nas entrevistas, realizadas individualmente em 2016, a Supervisora I e a coordenadora do CMADIJ falam dos atendimentos oferecidos pela equipe do CMADIJ e da parceria com a instituição privada de caráter assistencial nos atendimentos voltados à saúde:

\footnotetext{
Entrevistada: E hoje em dia.... nossa equipe hoje em dia....do...do...núcleo... investe MUITO mais na área pedagógica e a área que...que da saúde a gente faz?

Nós...temos uma parceria MUITO BOA com o CER /APAE, a gente encaminha tudo lá para o CER/APAE.

Pesquisadora: Sim, o CER/APAE é a clínica deles?

Entrevistada: Hoje a APAE atende TODOS os alunos, pelo menos todos os que a gente encaminha eles tentam... encaixar, sabe? Nas áreas que necessitam (Coordenadora do CMADIJ).

Pesquisadora: Existe relação do núcleo com outras instituições?

Entrevistada: Sim, existe uma relação mais próxima com a APAE por conta do CER.

Pesquisadora: Aham (sic).

Entrevistada: Porque a gente encaminha os alunos.

Pesquisadora: Certo.

Entrevistada: Né? Então, a APAE é o nosso. É o nosso forte por conta dos atendimentos clínicos, né?

(Supervisora I, Núcleo Inclusão Escolar e Diversidade).
}

As imbricações entre os setores público e privado se estabelecem mais uma vez com o desmonte do centro e encaminhamento de recursos públicos para uma instituição privada de caráter assistencial, local de funcionamento do CER. O campo da educação especial - ensino regular mais uma vez é colocado em disputa. Tal situação permeou a história da educação dos alunos com deficiência, conforme discutimos no capítulo II. Kassar (1995) pontua essa relação de disputa 
ao afirmar que apesar da previsão existente na legislação (Leis de Diretrizes e Bases da Educação de 1996, Constituição Federal de 1988) que contribuiu para a expansão do ensino, o especial e o regular são vistos como problemas distintos que disputam espaço, o mesmo lugar físico: a escola pública (grifos da autora).

Mesmo com a saída de grande parte da equipe do centro, os atendimentos foram mantidos, sendo ofertados atualmente apenas pelas profissionais psicopedagogas que atuam como assessoras técnicas. A imagem construída como local em que eram realizadas avaliações que contribuíam para o trabalho na unidade escolar se manteve. O centro prosseguiu (e ainda prossegue) com suas atividades, com os mesmos objetivos e ações, porém, com uma equipe reduzida de profissionais que tenta de diversas formas manter o trabalho. No próximo item discutiremos a atuação desses profissionais, também considerados como burocratas de médio escalão, mas que atuam como burocratas de nível de rua em determinadas ações (a exemplo das avaliações realizadas com os alunos e nas tratativas voltadas às famílias dos alunos).

\section{2. Interações dos agentes implementadores no âmbito da secretaria municipal de educação}

Burocratas de médio escalão são atores que desempenham função de gestão e direção intermediária, sendo eles gerentes, diretores, coordenadores ou supervisores em burocracias públicas ou privadas. Eles são responsáveis por operacionalizar as estratégias formuladas no escalão superior (LOTTA, PIRES, OLIVEIRA, 2015).

No presente trabalho consideramos burocratas de médio escalão os profissionais da Secretaria Municipal de Educação que integram a supervisão do Núcleo de Inclusão Escolar e Diversidade, coordenação e assessoria técnica do CMADIJ, no entanto, ressaltamos que esses agentes também atuam como burocratas de nível de rua, dependendo do público com quem interagem. Ao atuar diretamente com os alunos e suas famílias, tais atores encontram-se em contato direto com o público-alvo da política, implantando a política no nível de rua. Portanto, para conhecermos um pouco sobre o trabalho de cada um desses agentes 
implementadores, apresentamos o que foi observado no campo e, principalmente, o que foi apreendido nas entrevistas realizadas.

\subsection{1.}

\section{A atuação da supervisão do núcleo de inclusão escolar e diversidade}

O Núcleo de Inclusão Escolar e Diversidade, conforme apresentado no capítulo II é responsável pela implantação da política educacional voltada aos alunos com deficiência na rede municipal de ensino, sendo responsável pela equipe do CMADIJ.

Quanto à atuação de sua supervisão, destacamos que em um curto período de tempo (três anos) o núcleo contou com três supervisoras distintas. A atuação dessas agentes parece ser significativamente alterada conforme a profissional que ocupa a função, mostrando a discricionariedade da burocracia de médio escalão.

A Supervisora I, entrevistada em 2016 afirmou que sua atuação consistia na realização de palestras nas escolas, acompanhamento do trabalho das assessoras técnicas, principalmente por meio de relatórios e através do sistema utilizado pela secretaria (Sistema de Gestão em Educação - G-SEA) no qual são registradas as matrículas nas escolas. Conforme a supervisora, durante as palestras nas escolas eram fornecidas informações às equipes diretivas sobre os direitos dos alunos com deficiência (a necessidade de diminuição da quantidade de alunos em turmas que possuem aluno com deficiência matriculado, por exemplo), formação continuada da equipe de profissionais da escola e acompanhamento dos atendimentos realizados com os alunos com deficiência. A supervisora também contou que era responsável pelos Seminários de Educação Inclusiva do Programa Educação Inclusiva: direito à diversidade, que aconteceram na rede no período de 2004 a 2010. Durante sua atuação como supervisora do núcleo, o CMADIJ contava ainda com a coordenação, sendo a coordenadora o elo da equipe com a secretaria municipal de educação.

Já a Supervisora II, entrevistada em 2018, enfatizou que seu papel na supervisão é atuar de maneira extremamente próxima às assessoras técnicas, o que - segundo ela - lhe brinda a possibilidade de conhecer todos os 240 alunos com deficiência da rede, acompanhando de perto o trabalho de apoio feito nas escolas. 
Um dos fatores que contribui para essa situação parece ter sido a ausência da coordenação do CMADIJ a partir do ano de 2017. Durante o período de realização da pesquisa, a supervisão do núcleo era responsável pela equipe do CMADIJ e as assessoras técnicas se reportavam diretamente à supervisão do núcleo, sendo ela a chefia imediata das profissionais do centro.

Durante a entrevista, a Supervisora II ressalta que conhece muito bem o trabalho das assessoras técnicas, uma vez que compôs a equipe do CMADIJ como assessora de 2015 a 2017:

\footnotetext{
por eu ter essa vivência, e quando me convidaram pra fazer o trabalho de supervisão, eu to (sic) muito colada às minhas técnicas, muito colada que eu digo assim: TODOS os alunos da rede hoje eu conheço, são 240. TODOS eu acompanho com as técnicas" (Supervisora II, Núcleo de Inclusão Escolar e Diversidade).
}

Ela enfatiza que este é um dos diferenciais de sua atuação, pois procura tomar suas decisões baseando-se na sua experiência como assessora técnica. Ela marca constantemente seu local de fala e com muita cautela escolhe as palavras mais apropriadas para comparar seu trabalho com o das supervisoras que ocuparam o cargo anteriormente. Ressalta várias vezes que todas fizeram um bom trabalho, se esforçaram, mas que seu grande diferencial é que ela procura constantemente estar presente em todas as unidades escolares. De fato, durante a aplicação dos questionários, momento em que estive em todas as 16 unidades escolares da zona urbana e durante a observação do campo de pesquisa, pude observar a proximidade da supervisão com o trabalho desenvolvido nas escolas. A supervisora chegava nas escolas, conversava com a equipe de gestão (direção e/ou coordenação), conversava com a professora regente, com a profissional de apoio e com a professora do AEE.

Esse contato frequente e intenso com o contexto de trabalho das assessoras e dos demais agentes escolares, ainda que possa ser considerado relevante ou desejável, parece garantir a identificação de algumas questões problemáticas do trabalho, porém não necessariamente induz a uma reflexão ou intervenção sobre o fato de que os alunos com deficiência não estavam aprendendo a ler, por exemplo, o que em nenhum momento foi diagnosticado por ela como algo problemático durante toda a entrevista. Nesse contexto, os pequenos avanços dos alunos (mesmo que fossem apenas comportamentais e não relacionados à aprendizagem) 
foram apresentados com muita ênfase, indicando a percepção destes como uma grande conquista, como podemos verificar na fala de uma das agentes implementadoras: "Às vezes é um passo mais largo que você já fica mais feliz, né?" (Assessora Técnica II, CMADIJ) ao descrever uma aluna que antes não permanecia sentada por todo o período da aula e, atualmente, permanece.

Nesse aspecto, percebemos a marca do capacitismo, uma vez que as dificuldades enfrentadas pelos alunos com deficiência (como analfabetismo e retenção, por exemplo) não são aspectos enfatizados em nenhuma entrevista no âmbito da secretaria de educação, mesmo por aqueles que apresentam experiência no campo da educação especial. Martín (2017) afirma que os juízos de valor sobre as capacidades estão tão presentes na sociedade que seus efeitos excludentes acabam não sendo percebidos, nem questionados.

Ainda sobre a atuação das assessoras técnicas, a supervisora reconhece a necessidade de uma equipe mais completa, no entanto, ela afirma que a equipe do CMADIJ precisa atuar considerando sua condição atual. A supervisora relata não gostar que a equipe se refira com pesar ao período em que o centro funcionava com todos os atendimentos (educação, saúde e assistência) e enfatiza que o centro deve funcionar com o que existe de recurso disponível: "Não vamos ficar alimentando o que tínhamos. Vamos fazer aquilo que nós podemos fazer da melhor maneira possivel, com o que TEMOS!” (Supervisora II, Núcleo de Inclusão Escolar e Diversidade).

Segundo ela, as assessoras técnicas devem valorizar as experiências advindas do trabalho na educação especial e considerá-lo um ganho, pois considera que este trabalho contribua para um enorme crescimento pessoal. Ademais, ela ressalta que diante da ausência de melhores condições de trabalho, as profissionais do CMADIJ devem buscar "meios próprios" para que a atuação aconteça da melhor maneira possível.

O discurso aponta para uma perspectiva "missionária" em relação ao trabalho realizado com pessoas com deficiência. Tal situação pode ser justificada devido ao longo período em que a supervisora atuou na instituição privada de caráter filantrópico. 
Outro fator importante abordado durante a entrevista com a Supervisora II diz respeito às mudanças da gestão da secretaria municipal de educação. Ela afirma que 2018 foi um ano totalmente atípico, pois quando a nova equipe iniciou os trabalhos, receberam a informação de que haviam perdido o prazo para solicitar recursos ao Ministério da Educação e que não havia mais nada que pudesse ser feito, impactando negativamente as ações do ano todo devido à ausência de recursos advindos de emendas parlamentares ${ }^{68}$, a que ela se refere como "os extras". A entrevistada reitera que "por conta de uma situação de...que foi falta não sei se...o...outra gestão não tinha conhecimento, não atentou pro prazo." (Supervisora II, Núcleo de Inclusão Escolar e Diversidade).

Tal situação aponta para uma possível descontinuidade políticoadministrativa da gestão municipal. Por descontinuidade político-administrativa entendemos ser "a interrupção de projetos, obras e ações, e na reversão de prioridades e metas (NOGUEIRA, 2006 p.6). O autor ressalta que essas situações são julgadas como indesejáveis por resultarem na perda do conhecimento acumulado (ou memória institucional), reversão de avanços, descrenças ou desmotivação por parte dos envolvidos e provável desperdício de recursos públicos envolvidos (ibidem).

Assim, percebemos que no caso de Corumbá, a partir das mudanças de prefeitos, toda a estrutura é alterada sem considerar o trabalho realizado anteriormente e sem prestar informações necessárias para que a nova equipe pudesse realizar a continuidade dos trabalhos (transição). Os cargos de confiança são alterados e, aparentemente, levam-se em conta apenas as questões pessoais entre o prefeito e os secretários. As transições parecem desconsiderar o caráter público, no sentido republicano da gestão.

De Oliveira Estevam (2010) descreve essas mudanças advindas das transições de gestão como o momento em que aparentemente "tudo vai mudar". As atividades serão interrompidas, independentemente de uma avaliação de sua eficácia. Parte-se do pressuposto que o novo é o novo e o anterior é passado. Para que o novo possa se estabelecer é preciso romper com o passado (grifos do autor).

\footnotetext{
${ }^{68}$ São consideradas emendas parlamentares a municípios todas as emendas à Lei Orçamentária Anual (LOA) propostas por comissão, bancada ou parlamentares individuais aplicadas como transferências diretas a municípios (Sodré; Alves, 2010).
} 
Tal situação foi observada nas últimas três gestões da prefeitura apontando para um possível elemento de cultura institucional da gestão do município.

A respeito das continuidades e descontinuidades das políticas públicas, Spink (1987) ressalta o paradoxo democrático. Uma continuidade administrativa, ao manter a continuidade dos serviços evita a esquizofrenia organizacional, garante o crescimento de uma classe técnoburocrática, que possui poder devido ao seu conhecimento histórico das tentativas de operacionalizar a política pública pela força da continuidade. Por outro lado, Spink afirma que a descontinuidade garante que "o governo do dia" domine a máquina pública, em vez de ter que negociar com ela. A partir daí o autor questiona: "E o cidadão nisso tudo? Qual é, em outras palavras, o preço que estamos dispostos a pagar por nossa democracia?”(p. 64).

Retornando ao discurso da Supervisora II, sua fala também transparece em diversos momentos, a insegurança da ocupação do cargo, pois ela afirma diversas vezes que sua posição como supervisora do núcleo é transitória, uma vez que ela ocupa um cargo que pode ser alterado de acordo com as mudanças ocorridas na gestão do município. A supervisora fala sobre as atividades que deseja realizar durante os próximos anos, porém ressalta: "Isso aí, eu pretendo se ficar na supervisão, porque tudo é transitório, é cargo" (Supervisora II, Núcleo de Inclusão Escolar e Diversidade). Tal situação ocorre devido à ideia da descontinuidade, que já faz parte do imaginário social dos servidores, técnicos e assessores políticos. Tal crença é reforçada, principalmente em épocas de eleições, chamando a atenção para projetos que foram encerrados ou deixaram de ser prioridade (Nogueira, 2006).

Outra atribuição descrita pela supervisora refere-se à contratação dos profissionais de apoio e dos professores do AEE. A supervisora relata que a exigência para contratação é que o profissional tenha formação ou experiência na área da educação especial. A contratação ocorre por meio de análise de currículo e entrevista feita pela supervisora do núcleo.

Quanto à forma de contratação, a entrevistada afirma que a prefeitura pretende substituir o trâmite atual do processo seletivo pela realização de uma prova. A supervisora se mostra preocupada com a situação, pois afirma que a 
entrevista é extremamente necessária para que se conheça o professor. Ela afirma que tentará negociar a manutenção da entrevista no processo seletivo.

Esta situação nos mostra a atuação da supervisora como burocrata de médio escalão responsável pela definição dos agentes implementadores que atuam como burocratas de nível de rua. Nesse sentido Lotta, Pires e Oliveira (2015) ressaltam que os burocratas de médio escalão são o elo fundamental entre as regras e sua aplicação prática, entre o mundo da política e o implementador que se relaciona com o usuário, entre múltiplas agências e seus entendimentos para a construção de consensos sobre as políticas públicas.

$\mathrm{Na}$ linha de frente da implementação da política de educação especial no âmbito da secretaria municipal de educação estão localizadas as assessoras técnicas do CMADIJ. Elas são caracterizadas como burocratas de médio escalão, no entanto, em determinados momentos atuam como burocratas de nível de rua. A atuação dessas profissionais será abordada no item a seguir.

\subsection{2. \\ O trabalho das assessoras técnicas do CMADIJ}

As assessoras técnicas do CMADIJ são responsáveis pelo acompanhamento do atendimento educacional dos alunos com deficiência da rede municipal de ensino. O CMADIJ conta com seis assessoras técnicas, sendo cada uma responsável pelo acompanhamento de 5 a 6 escolas de um total de 35 unidades escolares (urbanas e rurais). O acompanhamento é realizado através de visitas periódicas estabelecidas por meio de um cronograma. As escolas recebem o cronograma com as datas das visitas e aguardam a vinda da assessora técnica para realizar o repasse das demandas existentes. Caso existam demandas fora da previsão de visita (reunião com responsável de aluno com deficiência e encaminhamento de aluno para avaliação, por exemplo) a presença da assessoria técnica é solicitada pela escola ao CMADIJ.

As assessoras técnicas do CMADIJ também são responsáveis pela avaliação dos alunos para possível encaminhamento ao atendimento educacional especializado. A partir da identificação da necessidade de avaliação é solicitado à 
coordenação da escola um questionário informativo ${ }^{69}$. A partir do preenchimento deste questionário, o professor entrega à coordenação, que solicita a avaliação do aluno ao CMADIJ. Para melhor visualizarmos o procedimento realizamos o fluxograma a seguir:

Figura 2: Fluxograma de encaminhamento de alunos ao CMADIJ.

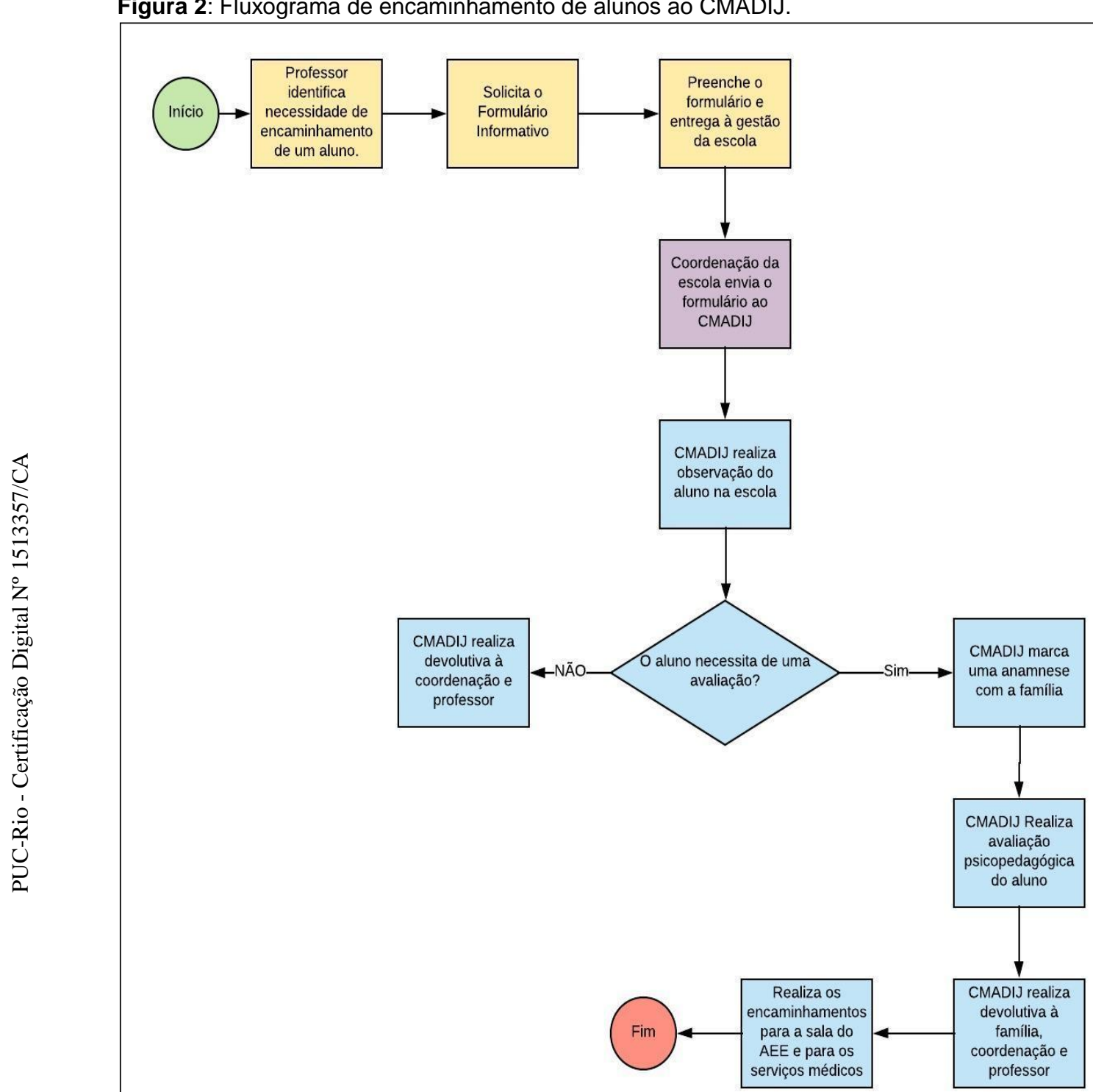

Legenda: verde: início do processo; amarelo: atuação docente; roxo: atuação da coordenação; azul: atuação do CMADIJ; vermelho: fim do processo.

Elaboração própria com uso da ferramenta www.lucidchart.com

${ }^{69}$ Elaborado pelo CMADIJ, o questionário informativo fica disponível na coordenação das escolas.O questionário encontra-se no anexo do presente trabalho. 
A partir do fluxograma apresentado, percebemos a atuação direta do CMADIJ em todo o processo. A respeito do encaminhamento, a atuação do professor e da gestão da escola consiste apenas em encaminhar.

Quanto ao questionário informativo, este é composto por perguntas que contém: dados do aluno (data de nascimento, filiação, endereço, telefone, escola, série), possível repetência (se sim, desde que ano); motivo do encaminhamento (neste o professor deve explicar com detalhes as principais dificuldades do aluno em sala de aula); quais os procedimentos pedagógicos utilizados com o aluno que apresenta dificuldades; durante quanto tempo esse aluno foi observado; informações sobre a interação família/escola/aluno; dificuldades/preocupações enquanto professor para atingir seus objetivos; existência de necessidade de adaptação curricular e acessibilidade no âmbito escolar e familiar.

Por meio do questionário, o CMADIJ realiza um primeiro levantamento das principais informações referentes ao aluno. $\mathrm{O}$ uso do questionário aponta para uma possibilidade da equipe do CMADIJ proporcionar ao professor a reflexão acerca de sua atuação, pois pede que ele descreva quais os procedimentos pedagógicos utilizados, por quanto tempo e se existe interação entre a família e a escola. Dessa forma, o professor poderia re(pensar) sua prática e verificar se de fato, aquele aluno constitui-se como público-alvo do CMADIJ. Em algumas unidades o questionário informativo é disponibilizado pela professora da sala de AEE, como no caso da Escola II, que descreve a situação ocorrida na unidade escolar e ressalta que alguns professores acabam não encaminhando o aluno após a solicitação de preenchimento do questionário informativo:

\footnotetext{
No último conselho que a gente teve eu peguei nome de uns 12 adolescentes. Aí a gente passou uma ficha ${ }^{70}$, a gente não teve devolutiva da ficha porque nesta ficha o professor vai relatar DE FATO o que ele fez de diferente para tentar cativar esse aluno. Daí a gente não teve essa devolutiva. (Professora do AEE, Escola II).
}

As assessoras técnicas do CMADIJ relataram na entrevista que, após o preenchimento do questionário informativo, elas realizam uma visita na escola para observar a rotina do aluno encaminhado. Após isso, elas solicitam a presença

\footnotetext{
${ }^{70}$ A professora refere-se ao questionário informativo como "ficha".
} 
dos responsáveis para uma entrevista, denominada por elas como anamnese ${ }^{71}$. Em seguida as profissionais fazem uma avaliação pedagógica e por fim, realizam a devolutiva para a coordenação da escola e para a família, momento em que irão comunicar se existe necessidade de encaminhamentos e, caso sim, quais serão realizados.

Após o encaminhamento, as assessoras técnicas também realizam o acompanhamento desses alunos nos mais diversos serviços (atendimentos educacionais especializados, atendimentos psicológicos, médicos, fonoaudiológicos, dentre outros) Importante ressaltar que, a partir da saída dos membros da equipe de saúde do CMADIJ no ano de 2013, conforme apresentado anteriormente, os profissionais psicopedagogos assumiram, de certa maneira, o papel dos profissionais da saúde ao realizarem agendamentos médicos, orientações quanto ao uso de medicamentos, acompanhamento dos atendimentos psicológicos, fonoaudiológicos, dentre outros.

As assessoras técnicas do CMADIJ realizam de uma maneira indireta, os atendimentos antes ofertados por outros profissionais, acompanham os alunos nos aspectos que extrapolam o âmbito pedagógico e dialogam com os profissionais que prestam atendimento. No entanto, em algumas situações, as assessoras relatam que esses profissionais desconsideram o contexto educacional dos alunos, enfatizando apenas os aspectos relacionados à saúde, uma vez que a atuação desses profissionais não se configura como de uma equipe multiprofissional. Sob o ponto de vista das assessoras do CMADIJ, isso dificulta ou mesmo inviabiliza o trabalho: "se a gente tivesse isso mais próximo de saúde e assistência, um vínculo que a gente tivesse sempre assim...conversando [...] o trabalho ia ter muito mais sucesso. Porque os trabalhos, eles acabam sendo muito..é...individualizados" (Assessora Técnica III, CMADIJ).

A atuação de equipe multiprofissional, além de ser uma prerrogativa do CMADIJ (incluída até mesmo na sua nomenclatura) é garantida pelas políticas propostas pelo governo federal para o atendimento educacional das pessoas com deficiência e orientada pelos documentos dos organismos internacionais, a

\footnotetext{
${ }^{71}$ No campo da saúde, a anamnese consiste na entrevista inicial que tem como objetivo coletar informações que irão auxiliar no processo diagnóstico.
} 
exemplo da Declaração de Salamanca, que preconiza a construção de uma "rede contínua de apoio, considerando a atuação de professores, psicólogos, fonoaudiólogos e terapeutas ocupacionais" (UNESCO, 1994). No âmbito do governo federal, a atuação de equipe multiprofissional é garantida desde a Política Nacional para a Integração da Pessoa Portadora de Deficiência ${ }^{72}$, lançada em 1999.

Ainda nesse sentido, as profissionais afirmam que sentem falta de uma equipe para realizar os atendimentos de maneira multidisciplinar, discutindo casos, considerando todas as especificidades do aluno e o contexto em que está inserido. Elas afirmam que os profissionais da saúde, por não atuarem no contexto da educação, acabam considerando os atendimentos individualizados como a única referência para o desenvolvimento dos alunos.

A assessora técnica I, ao contar sua trajetória, se queixa sobre a ausência dos profissionais da saúde no centro. Ela conta que o CMADIJ, na sua implantação, trabalhava com os atendimentos e também com a prevenção e orientação às unidades escolares, auxiliando na identificação das necessidades e realização dos encaminhamentos. A fala da assessora técnica é carregada de nostalgia ao se referir a esse período. Ela conta que o CMADIJ realizava campanhas, tais como: "Olho no olho"; "Quem ouve bem, aprende melhor". Seu relato dá a entender que o serviço prestado não era exclusivamente aos alunos com deficiência, pois as campanhas educativas as quais ela se refere possibilitavam que toda a unidade escolar recebesse informações sobre deficiências: "A gente trabalhava muito com a PREVENÇÃO naquela época" (Assessora Técnica I, CMADIJ).

A ação relatada pela entrevistada está de acordo com os preceitos trazidos pela Política Nacional de Educação Especial na Perspectiva da Educação Inclusiva, que orienta que os profissionais da educação especial devem atuar através de projetos em parceria com outras áreas, dentre elas, a saúde.

Além de realizar o processo de avaliação e acompanhamento dos atendimentos frequentados pelo aluno, o CMADIJ também realiza orientação aos

\footnotetext{
72 “A educação especial contará com equipe multiprofissional com a adequada especialização e adotará orientações pedagógicas individualizadas” (BRASIL, 1999 p.2).
} 
professores em relação à utilização de recursos de tecnologia assistiva ${ }^{73}$, ofertam formação continuada, principalmente aos professores do atendimento educacional especializado e profissionais de apoio.

Ainda sobre a atuação do CMADIJ destacamos alguns aspectos contraditórios. Mesmo sendo responsáveis pela avaliação e por todo o acompanhamento dos alunos com deficiência matriculados na rede municipal, as profissionais relatam sentir certa invisibilidade no seu trabalho, sobretudo nos casos em que o município é questionado pelos órgãos de controle, elas são procuradas para prestar informações a respeito dos atendimentos ofertados pelo centro e que são cobradas a dar respostas aos órgãos de controle, conforme relatos das Assessoras Técnicas II e III: "Quando entra no Ministério Público que a gente tem que responder" (Assessora Técnica II); “os pequenos avanços, essas coisas, ninguém enxerga, né? Mas aí quando é uma coisa mais assim, as pessoas enxergam” (Assessora Técnica III).

Esta situação demonstra que a responsabilidade em relação ao funcionamento da política de educação especial no município é transferida para a equipe do CMADIJ. Os discursos das assessoras técnicas evidenciam que, no âmbito da secretaria, os alunos com deficiência matriculados na rede "pertencem" a elas. As profissionais são responsabilizadas, sobretudo, quando a secretaria é notificada por algum órgão de controle. Esta situação aponta para o fato de que a secretaria municipal corrobora com a desresponsabilização de sua atuação perante os atendimentos realizados pelo centro.

Outro detalhe importante nas falas das assessoras técnicas do CMADIJ foi o uso do pronome possessivo todas as vezes que elas se referiam aos alunos atendidos. As profissionais se referiam aos alunos como "meu aluno", indicando sua atuação direta nos atendimentos, mesmo que elas não realizassem os atendimentos de maneira direta. Dessa forma, identificamos a ausência de um trabalho colaborativo no atendimento dos alunos com deficiência na rede municipal. Roldão (2007) define o trabalho colaborativo como um processo de

\footnotetext{
${ }^{73}$ Tecnologia Assistiva é uma área do conhecimento, de característica interdisciplinar, que engloba produtos, recursos, metodologias, estratégias, práticas e serviços que dão mais autonomia, independência e qualidade de vida a pessoas com deficiência, incapacidades ou mobilidade reduzida (BRASIL, 2009b).
} 
trabalho "articulado e pensado em conjunto, que permite alcançar melhor os resultados visados, com base no enriquecimento trazido pela interação dinâmica de vários saberes específicos e de vários processos cognitivos em colaboração" (p.27). No que se refere ao trabalho docente, a autora enfatiza que o uso do pronome possessivo ("meu aluno") é corriqueiro e consistem em um reflexo discursivo de uma concepção individual (ainda que afetuosa) da ação de ensinar.

Quanto às relações com as unidades escolares, a situação relacionada à responsabilização do CMADIJ a respeito do atendimento educacional dos alunos com deficiência também as assessoras priorizam a participação dos coordenadores das escolas com o intuito de fazer com que eles se envolvam nas situações, porém, a responsabilidade e, sobretudo, as cobranças sobre os atendimentos desses alunos não recai diretamente na figura da direção/coordenação da escola ${ }^{74}$.

Ainda a respeito da sensação de invisibilidade sentida pelas agentes, a assessora técnica I enfatiza em algumas unidades escolares elas são denominadas como "técnicas da secretaria" e não como as profissionais do CMADIJ ou como as técnicas da educação especial. Nesse sentido, a assessora técnica III, relata que quando atuava como profissional de apoio no ano de 2013 não conhecia o trabalho do centro, acreditando que a responsabilidade pelo aluno com deficiência era toda dela: "antes de vir pra cá eu não conhecia...é...efetivamente como que funcionava o trabalho do CMADIJ" (assessora técnica III).

As assessoras técnicas também ressaltam as relações existentes com as famílias dos alunos com deficiência. Segundo elas, as famílias são parte importante do processo, pois são responsáveis por possibilitar que os alunos frequentem os atendimentos durante o contraturno escolar. Nos casos em que a família não leva o aluno nos atendimentos, o CMADIJ adota procedimentos estratégicos que envolvem assinatura de documento, por exemplo, informando que serão tomadas medidas judiciais devido à ausência do aluno no atendimento educacional especializado. Percebemos que, além de servir como um instrumento de pressão, o documento é usado como comprovação de que o atendimento foi ofertado pela rede municipal, mas a família não possibilitou que o aluno o

\footnotetext{
${ }^{74}$ A atuação dos diretores e coordenadores serão apresentadas no capítulo IV.
} 
frequentasse. Essa é uma forma de garantir que o CMADIJ não seja responsabilizado, posteriormente, pela opção da família de não receber o atendimento.

A esse respeito, as assessoras destacam que mesmo que tomem atitudes com o objetivo de pressionar a família para garantir a frequência dos alunos nos atendimentos, elas afirmam que o contato com as famílias não deve ser feito exclusivamente por elas, mas também pelo diretor da escola.

Outra estratégia relatada pela equipe para tentar garantir que a família leve o aluno para os atendimentos devidos é relacionada à ameaça de suspensão do Benefício de Prestação Continuada (BPC) ${ }^{75}$. A assessora técnica III descreve uma situação em que um aluno possuía muitas faltas no atendimento educacional especializado e diante disso, ela chama a responsável para uma conversa e informa que, caso ele não frequente os atendimentos, o recebimento do BPC será suspenso. Ela também afirma que se utiliza dessa estratégia nos casos em que a família não compra os medicamentos necessários para os alunos. A assessora técnica III complementa o exemplo dado, dizendo que o recebimento do benefício é a justificativa utilizada por ela para que a família garanta a medicação, independente do preço do remédio.

As estratégias descritas configuram-se como práticas discricionárias utilizadas pelas agentes, que nessa atuação assumem características de burocratas de nível de rua, uma vez que lidam diretamente com o público alvo da política pública. Dessa forma, as assessoras técnicas do CMADIJ também podem ser consideradas como agentes híbridos, pois atuam em determinados momentos como BME e em outros como BNR.

A maior atuação das assessoras técnicas como BNR também é um resultado da ausência de profissionais no CMADIJ para desempenhar funções específicas. Um exemplo é a fala da Assessora Técnica III, que relata um diálogo com a responsável de um aluno:

\footnotetext{
75 O Benefício de Prestação Continuada é um direito adquirido por meio da Constituição Federal de 1988, que consiste no pagamento de um salário mínimo mensal à pessoa com deficiência e ao idoso acima de 65 anos que comprovem incapacidade para a vida laboral, atestada por meio de avaliação médica e social realizada pelo Serviço de Perícia Médica do INSS e por um profissional do Serviço Social, respectivamente.
} 
Entrevistada: Inclusive, eu falei assim:

-Você tá recebendo o benefício.

- Ah, mas a gente só tem a outra Ritalina cara...

- Mas você tem o benefício!

[...] Então, assim. A gente tem que dar essas apertadas (Assessora Técnica III, CMADIJ).

Ela ressalta que a família possui obrigação em garantir a compra de medicação do aluno, no entanto, o contexto socioeconômico dessa família não é considerado. Muitas vezes, o BPC é a única fonte de renda da família da pessoa com deficiência. Camargo (2011), em pesquisa realizada em Corumbá/MS, verificou que o benefício constitui não só a única renda de várias famílias de pessoas com deficiência, mas sua garantia da sobrevivência, minimizando a situação de pobreza $^{76}$.

Dessa forma, destacamos a necessidade de realização de um trabalho intersetorial, conforme prerrogativa da Política Nacional de Educação Especial na Perspectiva da Educação Inclusiva que apresenta como um de seus objetivos a "articulação intersetorial na implementação de políticas públicas" (BRASIL, 2008 p. 14). Por intersetorialidade, entendemos ser a "articulação de saberes e experiências no planejamento, realização e avaliação de ações, com o objetivo de alcançar resultados integrados em situações complexas" (JUNQUEIRA; INOJOSA; KOMATSU, 1997).

Jaccoud (2016) ressalta que o tema da intersetorialidade vem ganhando destaque como importante estratégia para a gestão pública, principalmente diante de problemas caracterizados como complexos e de públicos marcados por vulnerabilidades. Assim, destacamos a necessidade de um trabalho que envolva uma rede de profissionais, tanto da área da educação quanto saúde e assistência.

Enfatizamos que não seria correto responsabilizar as profissionais por essa atuação, uma vez que essa atividade não pertence à sua atribuição como profissional de pedagogia. As estratégias descritas por elas acabam sendo utilizadas com o objetivo de garantir o atendimento e a qualidade de vida do aluno.

Joaquim (2006) ao pesquisar a implementação de políticas da educação especial no município de Campinas no período entre 1989 a 2004 destacou a

${ }^{76}$ O objetivo da pesquisa foi averiguar os impactos do BPC na inserção de pessoas com deficiência intelectual no mundo do trabalho. 
inexistência ou insuficiência de um trabalho intersetorial, impossibilitando um atendimento mais consistente e complexo, como a situação do aluno com deficiência exige.

O trabalho em rede possibilita que as ações voltadas a todos os alunos, principalmente os com deficiência ganhem efetividade. Bendinelli, Andrade e Prieto (2012) afirmam que, embora as garantias legais que estabelecem o direito à educação dessa população tenham se firmado nos últimos anos, ainda há muito que intervir para que as práticas se aproximem das diretrizes da educação inclusiva. Uma das orientações refere-se à constituição de redes de apoio. As autoras apontam situação similar em São Paulo, à encontrada no presente trabalho, e afirmam que:

[...] não localizamos ações articuladas entre, por exemplo, educação, saúde e assistência social, o que se refletiu nas ações dos centros que, para tentarem sanar as demandas por esses serviços, utilizavam-se dos convênios ou parcerias com instituições privadas, ou realizavam ações pontuais junto aos serviços públicos antes referidos (BENDINELLI, ANDRADE e PRIETO, 2012 p. 21).

Na presente pesquisa, o CMADIJ assume essa mesma posição, de buscar parcerias com instituições privadas de caráter assistencial e de preencher as lacunas deixadas pela ausência de uma equipe multidisciplinar completa. Eles orientam as escolas e as famílias sobre as mais diversas temáticas, desde os aspectos pedagógicos até orientações sobre medicamentos, características fisiológicas da deficiência, entre outros aspectos.

$\mathrm{O}$ desmonte da equipe multidisciplinar do CMADIJ culminou nessa situação, apontando para a responsabilidade dos agentes do alto escalão do município que, de acordo com as informações levantadas nas entrevistas, foram os responsáveis pelo fim da articulação das secretarias de educação e saúde na oferta de profissionais ao centro. Sobre esse aspecto, Jaccoud (2016) afirma que a efetivação das políticas públicas sofre a influência de trajetórias históricas e institucionais, sendo a interdisciplinaridade, a transversalidade e a intersetorialidade termos que se associam à estratégias de gestão.

A articulação entre as diferentes ofertas setoriais traduziria, ao mesmo tempo, um duplo reconhecimento: o do usuário em sua trajetória pelas diversas políticas e o dos chamados problemas multidimensionais, cuja causalidade não pode ser creditada a um único setor ou dimensão. Em geral, a intersetorialidade vem tendo destaque no debate sobre a pobreza, entendida como problema complexo, em torno do qual vem se ampliando a reclamação por uma gestão pública mais integrada, com capacidade estatal e institucional 
adensada, maior capacidade de diálogo e partilha de recursos entre políticas setoriais, e mais mobilização de vontade política visando à colaboração (JACCOUD, 2016 p. 29).

Para Cunill-Grau (2016), a intersetorialidade é "parte central das políticas sociais ao ponto de aparecer como a nova promessa em matéria de gestão para traçar objetivos de transformação social” (p.35). Como os autores, destacamos a real necessidade de alteração da organização das políticas a partir da instauração de procedimentos que possibilitem os atendimentos em rede numa construção intersetorial das políticas públicas educacionais.

Além disso, a atuação dos profissionais que atuam na educação especial em parceria com outras áreas é referendado na Política Nacional da Educação Especial na Perspectiva da Educação Inclusiva (2008) que prevê a atuação de sistemas educacionais inclusivos na busca de acessibilidade arquitetônica, atendimentos de saúde, promoção de ações de assistência social, trabalho e justiça.

Em relação à perspectiva das assessoras técnicas sobre o trabalho dos professores, destacamos a ênfase dada à necessidade de um profissional que tenha "perfil" para trabalhar com alunos com deficiência. Elas descrevem que os professores devem ir muito além do ensinar, auxiliando o aluno em suas necessidades básicas: "pra trabalhar com criança deficiente você tem que ter perfil. Você não pode ter nojo, você tem que tá pronto pra trocar, pra limpar, pra lavar" (Assessora Técnica III, CMADIJ). Elas enfatizam que caso o profissional não apresente o chamado perfil, ele não deve permanecer. $O$ discurso das profissionais demonstra proximidade com a fala da Supervisora II, demonstrando mais uma vez a perspectiva do trabalho na educação especial como algo filantrópico, caritativo.

A partir da discussão apresentada referente ao trabalho dos burocratas de médio escalão no âmbito da secretaria municipal de educação, apresentaremos no próximo capítulo a implementação da política no âmbito das unidades escolares, abordando a atuação dos diretores, coordenadores, professores e profissionais de apoio e suas relações com o público alvo da política da educação especial e com os demais agentes implementadores. 


\section{4 \\ A IMPLEMENTAÇÃO DA POLÍTICA DE EDUCAÇÃO ESPECIAL NA PERSPECTIVA DOS AGENTES IMPLEMENTADORES NO ÂMBITO DAS ESCOLAS}

O presente capítulo apresenta as discussões no âmbito das unidades escolares. Para tanto, inicialmente apresentaremos os dados do Survey-GESQ Corumbá e os critérios de escolha das três unidades escolares referentes à segunda fase da pesquisa. Em seguida apresentamos de maneira mais detalhada as três unidades escolares utilizando os dados do Censo Escolar 2016, os resultados do survey e as observações feitas durante o trabalho de campo. A segunda fase da pesquisa contou com a participação de 24 agentes, sendo eles: 5 professores regentes, 2 profissionais de apoio, 3 professores do atendimento educacional especializado, 4 coordenadores, 1 diretora pedagógica e 3 diretores administrativos. Importante ressaltar que os 6 agentes da secretaria municipal de educação (Núcleo de Inclusão Escolar e Diversidade e CMADIJ), apresentados no capítulo III estão incluídos no número total de 24 participantes da segunda fase da pesquisa. Com o objetivo de mantermos o sigilo dos participantes da pesquisa, as escolas foram identificadas por números.

Ainda neste capítulo iremos apresentar as percepções dos agentes que atuam nas unidades escolares, acerca do conceito de deficiência e sobre conceito de educação inclusiva. A escolha desses conceitos ocorreu com o objetivo de averiguar o conhecimento dos agentes e suas concepções a respeito da deficiência e da inserção dos alunos com deficiência no ensino regular. Por fim, abordamos a discussão referente à atuação dos agentes implementadores no âmbito das unidades escolares, considerando suas condições no contexto da unidade e suas interações com os atores que implementam a política nas escolas e na secretaria 


\section{1.}

A pesquisa em Corumbá: aplicação do survey e estudos em escolas.

O survey utilizado na pesquisa foi o Survey GESQ, elaborado no trabalho de doutoramento da professora Ana Cristina Prado de Oliveira $^{77}$ em colaboração com o Grupo de Pesquisa Gestão Escolar e Qualidade na Educação (GESQ), ao qual foram incorporadas pequenas alterações para adequar o instrumento ao objeto da pesquisa em tela. O Survey GESQ foi criado com o objetivo de ampliar a discussão a respeito do trabalho de diretores, coordenadores e professores, considerando as dimensões de gestão, liderança e clima escolar, através da construção de novos itens elaborados especificamente para a mensuração desses conceitos (Oliveira, 2015).

Para utilização na pesquisa, inserimos questões relacionadas à formação e experiência dos agentes no campo da educação especial, além de itens voltados às expectativas a respeito da formação dos alunos com deficiência. A partir das alterações realizadas aplicamos o Survey GESQ-Corumbá 2017 no período de agosto a dezembro de 2017. Participaram da pesquisa 14 diretores, 96 professores e 24 membros da equipe de gestão (direção pedagógica e coordenação) de 16 escolas urbanas municipais de Corumbá. A seguir, apresentamos o universo da primeira fase da pesquisa.

Tabela 4: Número de participantes da pesquisa e total de escolas, diretores, equipe de gestão e professores das escolas da rede municipal de ensino de Corumbá MS.

\begin{tabular}{|c|c|c|c|c|c|c|c|}
\hline $\begin{array}{c}\text { Escolas } \\
\text { Municipai } \\
s \\
\text { Urbanas- } \\
\text { total }\end{array}$ & $\begin{array}{c}\text { Escolas } \\
\text { Municipais } \\
- \\
\text { participante } \\
\mathbf{s}\end{array}$ & $\begin{array}{l}\text { Diretore } \\
s-\text { total }\end{array}$ & $\begin{array}{c}\text { Diretores - } \\
\text { participante } \\
\text { s }\end{array}$ & $\begin{array}{l}\text { Equip } \\
\text { e de } \\
\text { gestã } \\
0- \\
\text { total }\end{array}$ & $\begin{array}{c}\text { Equipe de } \\
\text { gestão - } \\
\text { participante } \\
\text { s }\end{array}$ & $\begin{array}{c}\text { Professore } \\
\text { s - total }\end{array}$ & $\begin{array}{c}\text { Professore } \\
\text { s - } \\
\text { participante } \\
\text { s }\end{array}$ \\
\hline 16 & 16 & 16 & 14 & 63 & 24 & 507 & 96 \\
\hline $100 \%$ & $100 \%$ & $100 \%$ & $87 \%$ & $100 \%$ & $38 \%$ & $100 \%$ & $18,93 \%$ \\
\hline
\end{tabular}

Fonte: Elaboração própria com base nos Microdados do Censo Escolar, MEC/INEP (2017) e site da Prefeitura Municipal de Corumbá.

A gestão das escolas municipais de Corumbá conta com os seguintes componentes: diretor (a) da unidade escolar, diretor (a) adjunto (a), denominado também de diretor (a) pedagógico (a) e coordenador (a). O questionário foi

\footnotetext{
${ }^{77}$ Oliveira, A.C.P. As relações entre Direção, Liderança e Clima Escolar em escolas municipais do Rio de Janeiro. Tese de Doutorado, PUC-Rio, 2015.
} 
destinado a todos os membros da gestão da escola e a todos os professores, incluindo os professores do atendimento educacional especializado.

Inicialmente, a organização da aplicação ocorreu através da separação das escolas por região, a fim de garantir a visita de 2 a 3 escolas por dia. Todos os questionários foram entregues com o respectivo TCLE (Termo de Compromisso Livre e Esclarecido, em anexo). Selecionamos 16 escolas da zona urbana do município de Corumbá que ofertam o Ensino Fundamental I e Ensino Fundamental II. No universo das 24 escolas da zona urbana não foram escolhidas para a pesquisa os Centros de Municipais de Educação Infantil (CEMEI).

Neste item apresentaremos alguns resultados referentes à aplicação do survey. Vale ressaltar que Survey GESQ-Corumbá 2017 contava com dois questionários, um com 31 perguntas destinadas aos diretores e coordenadores da escola e o outro, com 29 perguntas, destinado aos professores. Neste item apresentaremos inicialmente o perfil dos participantes e abordaremos alguns aspectos relevantes para o trabalho.

Os diretores participantes, em sua maioria, são do sexo feminino $(75 \%)$ e $42 \%$ estão na direção das respectivas escolas no período entre 11 e 15 anos, caracterizando um longo período na gestão da escola. Todos(as) já haviam atuado antes como professores regentes. Quanto à qualificação, 75\% afirmaram já ter participado de curso de qualificação na área de gestão escolar, $75 \%$ possuía especialização e os outros $25 \%$, mestrado.

Em relação aos 96 professores participantes da pesquisa, $76 \%$ eram do sexo feminino, possuíam idade entre 30 e 49 anos (79\%). Quanto à experiência profissional na rede, $22 \%$ deles atuavam na rede municipal de ensino entre 10 a 14 anos e outros $20 \%$ atuavam há mais de 15 anos. A maioria dos respondentes lecionava nas séries iniciais do Ensino Fundamental (45\%). Quanto à formação, grande parte possuía especialização (66\%). O survey mostrou que $68 \%$ deles trabalhavam com carga horária de $20 \mathrm{~h}$ e $55 \%$ eram professores contratados, ou seja, possuíam um vínculo temporário com a rede pública municipal.

Como observa Oliveira (2007) na década de 1990, os trabalhadores da educação na América Latina sofreram grandes perdas econômicas. Em particular a autora registra que a política salarial do setor público no Brasil possui grande 
diversidade. No caso dos professores, os vencimentos tendem a ser diferentes conforme suas carreiras, contratos de trabalho (efetivo ou temporário), cargo, regime de trabalho, nível, classe, tempo de serviço, gratificações incorporadas e titulações.

O salário dos professores da rede municipal de Corumbá está acima da média salarial dos professores que atuam nos municípios do Brasil. Em estudo realizado em 2014 e divulgado em 2017, o INEP aponta que a média salarial dos professores das redes municipais com carga horária de $40 \mathrm{~h}$ semanais é de $\mathrm{R} \$ 3.116,35$ (INEP, 2017). O piso salarial nacional do magistério é de $\mathrm{R} \$ 2.455,35$ para $40 \mathrm{~h}$ de trabalho. Em Corumbá, um professor em início de carreira em Corumbá recebe o valor de $\mathrm{R} \$ 3.514,32$ para $40 \mathrm{~h}$ de trabalho, com especialização o valor sobe para $\mathrm{R} \$ 4.568,62$. Já com mestrado o docente recebe o valor de $\mathrm{R} \$ 5.622,92$ e com doutorado $\mathrm{R} \$ 7.028,64$.

Os 24 respondentes que eram membros das equipes de gestão eram em sua maioria do sexo feminino (80\%) na faixa etária entre 40 a 49 anos (50\%). Em termos de experiência profissional, 70\% deles atuavam na gestão da escola há até 5 anos. No tocante à formação, $90 \%$ deles possuía curso de especialização, no entanto, $55 \%$ não possuía curso de formação na área de gestão escolar. Em relação à experiência em sala de aula, $75 \%$ deles afirmaram já ter atuado como professor.

Em relação à identificação dos alunos, o questionário aplicado aos diretores indagava: "como o aluno com deficiência é identificado na escola?” Dos 12 diretores respondentes, 8 disseram que a informação é fornecida pela família no ato da matrícula, outros 5 informaram que o professor identifica em sala de aula e informa a gestão da escola, 2 disseram que a família informa à escola após o início das aulas. Vale ressaltar que alguns diretores escolheram mais de uma alternativa.

A resposta trazida pelos diretores corrobora com o que a coordenadora do CMADIJ e gestora do Núcleo de Inclusão Escolar e Diversidade apontou durante as entrevistas realizadas no ano de 2016. Nas entrevistas ambas informaram como ocorre a matrícula na rede municipal. Segundo elas, a rede municipal de Corumbá possui sistema de matrículas online, no qual as famílias fazem a opção quanto à escola que desejam matricular seus filhos e realizam toda a tramitação via 
internet. $\mathrm{O}$ formulário de preenchimento possui um campo específico para dados sobre diagnóstico de deficiência do aluno matriculado. Assim, se a família informa no ato da matrícula a deficiência (caso o aluno tenha), o CMADJI, automaticamente recebe a informação por meio do acesso ao sistema de matrícula. A gestora do núcleo afirma que ocorrem situações em que os pais (ou responsáveis) omitem a informação a respeito da deficiência do aluno. De acordo com as entrevistadas, nessas situações o núcleo orienta os pais junto à escola, mostrando as ações realizadas para esses estudantes. Segundo elas, há uma grande preocupação em relação a essas situações, pois a omissão influencia na organização da escola quanto à lotação dos alunos em sala de aula.

Sobre as formações em educação especial, a gestora do núcleo e a coordenadora do CMADJI relataram durante as entrevistas que também trabalham com formação nesta área. Entretanto, as respostas dos questionários mostraram que poucos diretores das escolas possuíam tal formação. Dos 14 participantes, 10 afirmaram não possuir formação na área de educação especial. Apenas um respondeu de maneira afirmativa e um deles não respondeu a este questionamento. Já dos 24 membros da equipe de gestão participantes, 13 informaram não possuir formação na área e os outros responderam de maneira afirmativa.

$\mathrm{Na}$ segunda fase da pesquisa retomamos o questionamento a respeito da oferta de formação continuada por parte da secretaria. Os coordenadores informaram que participam de formação na secretaria de educação e atuam como multiplicadores nas unidades escolares. Tal situação pode explicar a diferença entre a formação dos diretores e coordenadores presente nos dados do survey. Importante ressaltar que, alguns agentes relataram que as chamadas formações são na realidade reuniões para repasse de informações.

Tabela 5: Experiência da direção, professores e equipe de gestão das escolas participantes quanto à Educação Especial.

\begin{tabular}{cccccc}
\hline Profissional & $\begin{array}{c}\text { Até 1 } \\
\text { ano }\end{array}$ & Entre 1 e 3 & Acima de 3 & $\begin{array}{c}\text { Não possui } \\
\text { experiência }\end{array}$ & Não respondeu \\
\hline Diretores & 1 & 1 & 6 & 6 & - \\
Professores & 24 & 12 & 16 & 43 & 1 \\
Equipe de gestão & - & 3 & 8 & 12 & 1 \\
\hline Fonte: Survey GESQ-Corumbá, 2017. & &
\end{tabular}


Sobre a experiência na área da educação especial, observamos que 8 dos 14 diretores participantes possuíam acima de 1 ano, sendo 6 deles com mais de 3 anos de experiência na educação especial. Os coordenadores, em sua totalidade informaram possuir experiência acima de 1 ano, sendo 8 deles com mais de 3 anos. Tal situação pode estar relacionada com a experiência dos diretores e coordenadores em sala de aula, uma vez que todos os diretores afirmaram possuir experiência docente, bem como $75 \%$ dos membros da equipe de gestão.

Quanto ao fornecimento de materiais/informações sobre as políticas públicas voltadas às pessoas com deficiência, 64\% dos diretores afirmaram receber os materiais da Secretaria de Educação, apenas $14 \%$ deles disse não receber e buscar as informações por conta própria e os outros $22 \%$ disse receber essas informações do Ministério da Educação. Já a maioria dos membros das equipes de gestão informou não receber tais materiais/informações, sendo necessário buscar por conta própria (45\%), 40\% deles disse receber da Secretaria Municipal de Educação, 10\% recebe do MEC e 5\% deles não recebe e não busca esses materiais/informações.

Para os professores, por outro lado, a maior parte do material/informações recebida vem das equipes de gestão, sendo que $29 \%$ afirmou receber os materiais da coordenação da escola e $24 \%$ afirmou que não recebe nenhum material e que busca informações por conta própria. Outros $20 \%$ afirmou receber os materiais do diretor da escola. Essa diversidade de respostas indica que não existe uma padronização no fluxo das informações, pois em algumas escolas a coordenação ou direção pedagógica realiza o repasse e em outras o repasse dos materiais é feito pelo diretor. Nas entrevistas realizadas na segunda parte da pesquisa, a maior parte dos professores informou que busca auxílio das coordenações e dos professores do AEE, nos casos em que a escola conta com a sala de recursos multifuncionais.

Estes dados apontam para a relevância também da formação inicial desses profissionais. Verificamos que $73 \%$ dos professores são formados em instituição pública. Quanto aos diretores, todos os participantes se formaram em instituição pública e a mesma situação se aplica às equipes de gestão. Dos professores 
participantes $57 \%$, 55\% da equipe de gestão e $100 \%$ dos diretores possui formação em pedagogia.

No município de Corumbá, a Universidade Federal de Mato Grosso do Sul, Campus do Pantanal possui um curso de Pedagogia que apresenta carga horária considerável na área da Educação Especial, sendo ofertadas várias disciplinas que abordam tal temática (Introdução à Educação Especial - 51h; Práticas Pedagógicas e Pesquisa I (Educação Especial) - 51h; Direitos Humanos e Educação Inclusiva - 51h, sendo disciplinas obrigatórias e Adaptações curriculares na Educação Inclusiva - 51h; Tópicos Especiais em Educação Especial - 51h; Educação Saúde e Inclusão - 51h; Introdução ao Braille - 51h; Recursos Pedagógicos para o aluno com Deficiência Visual - 51h; Tópicos Especiais em Educação para a Diversidade - 51h; Altas habilidades/ superdotação em sala de aula: estratégias de identificação - 51h; Confecção de materiais adaptados - 51h; Distúrbios/Transtornos de Aprendizagem - 51h; Saberes e Práticas Inclusivas na Educação Infantil - 51h; Libras: noções básicas I - 34h; Libras: noções básicas II - 34h, como disciplinas complementares) (UFMS, 2019). A grade, que já contava com grande quantidade de carga horária em anos anteriores, ganhou ainda mais horas no ano de 2019.

A respeito da expectativa em relação à chegada desses alunos à universidade, perguntamos aos participantes quantos alunos com deficiência daquela escola, eles acreditavam que chegariam até a universidade. Os resultados são apresentados na tabela a seguir:

Tabela 6: Quantos alunos com deficiência desta escola você acredita que chegarão à universidade?

\begin{tabular}{cccc}
\hline & Diretores & Equipe de Gestão & Professores \\
\hline $\begin{array}{c}\text { Todos ou } \\
\text { quase todos } \\
\text { Um pouco } \\
\text { mais da } \\
\text { metade }\end{array}$ & - & 3 & 25 \\
$\begin{array}{l}\text { Um pouco } \\
\text { menos da } \\
\text { metade }\end{array}$ & 1 & 4 & 14 \\
$\begin{array}{c}\text { Muito Poucos } \\
\text { Não }\end{array}$ & 7 & 2 & 17 \\
respondeu & - & 11 & 25 \\
\hline Fonte: Survey GESQ-Corumbá 2017 & - & 15 \\
\hline
\end{tabular}

Fonte: Survey GESQ-Corumbá, 2017. 
Sobre a expectativa dos participantes a respeito dos alunos com deficiência matriculados na escola verificamos que a maior parte dos professores (67\%), diretores $(71 \%)$ e membros da equipe de gestão $(71 \%)$ consideram importante que eles consigam acompanhar o conteúdo no tempo deles, mesmo que não acompanhem toda a turma.

Caiado e Laplane (2009) afirmam que, inicialmente, a preocupação em relação às pessoas com deficiência era voltada ao aumento do número de matrículas nas escolas, porém, hoje esses alunos já estão dentro da escola e outras questões se colocam, tais como: os alunos aprendem? Como ensina-los? Como formar os docentes para essa nova organização da escola? Tal situação pode ser vista nas respostas obtidas em relação a aprendizagem desses alunos. Grande parte dos participantes afirmou que espera que eles consigam acompanhar o conteúdo no tempo deles.

É interessante observar que o questionário não abordava deficiências específicas (intelectual, visual, auditiva, por exemplo) e ainda assim, ao responder a pergunta, os participantes afirmaram que os estudantes devem acompanhar o conteúdo no tempo deles, mesmo que não acompanhem a turma. Pode-se assim levantar a hipótese de que a percepção sobre a deficiência estaria mais relacionada à existência de um atraso cognitivo ou limitações que impossibilitam a aprendizagem de uma maneira geral (VALLE; CONNOR, 2014). Outro fator que pode ser destacado é a provável vinculação da deficiencia com o fracasso escolar.

Em relação à percepção dos diretores e coordenadores, verificamos que a maior parte dos respondentes acredita que poucos alunos com deficiência da escola em que atuam conseguirão chegar à universidade. Tal situação pode estar relacionada à ideia da deficiência como algo relacioado ao fracasso escolar crença de que a deficiência é incapacitante. Já em relação ao professores, as opiniões ficaram distribuídas, apresentando resultados iguais entre os que acreditam que todos ou quase todos poderão chegar à universidade e entre os que acreditam que muito poucos chegarão ao nível superior. Abordaremos as expectativas dos agentes a respeito dos alunos com deficiencia mais adiante.

A partir da aplicação dos questionários verificamos que a atuação da direção da unidade escolar em relação aos atendimentos/encaminhamentos dos 
alunos com deficiência não possuía representatividade, uma vez que as demandas eram encaminhadas ao CMADIJ. Dessa forma, buscamos na segunda fase da pesquisa averiguar como ocorria a atuação de toda a equipe gestora da escola e dos professores, além das interações existentes com a assessoria técnica do CMADIJ.

Durante a fase de pesquisa empírica, participaram três escolas da rede municipal, escolhidas a partir dos resultados da aplicação do survey e dados do Censo Escolar 2016. Os critérios basearam-se na maior quantidade de alunos com deficiência matriculados, quantidade de participantes que responderam ao Survey GESQ-Corumbá, 2017, existência de sala de recurso multifuncional, sendo que uma das unidades (Escola IV) foi escolhida por possuir grande número de alunos com deficiência matriculados e não possuir sala de recursos multifuncional, nem profissional de apoio. O objetivo da escolha foi verificar como a implementação da política acontece no caso de uma unidade que não oferta o serviço. A seguir, apresentaremos os dados que basearam a escolha das três escolas.

A tabela a seguir mostrará as escolas participantes da primeira fase da pesquisa quanto às séries que ofertam, se possuem sala de atendimento educacional especializado, total de alunos matriculados no ano de 2016 (de acordo com os microdados do Censo Escolar), número de alunos com deficiência matriculados, quantidade de professores, diretores e demais membros da equipe de gestão que participaram da pesquisa. 
Tabela 7: Informações sobre as escolas quanto às séries, atendimento educacional especializado, número de alunos com deficiência e quantidade de participantes da pesquisa.

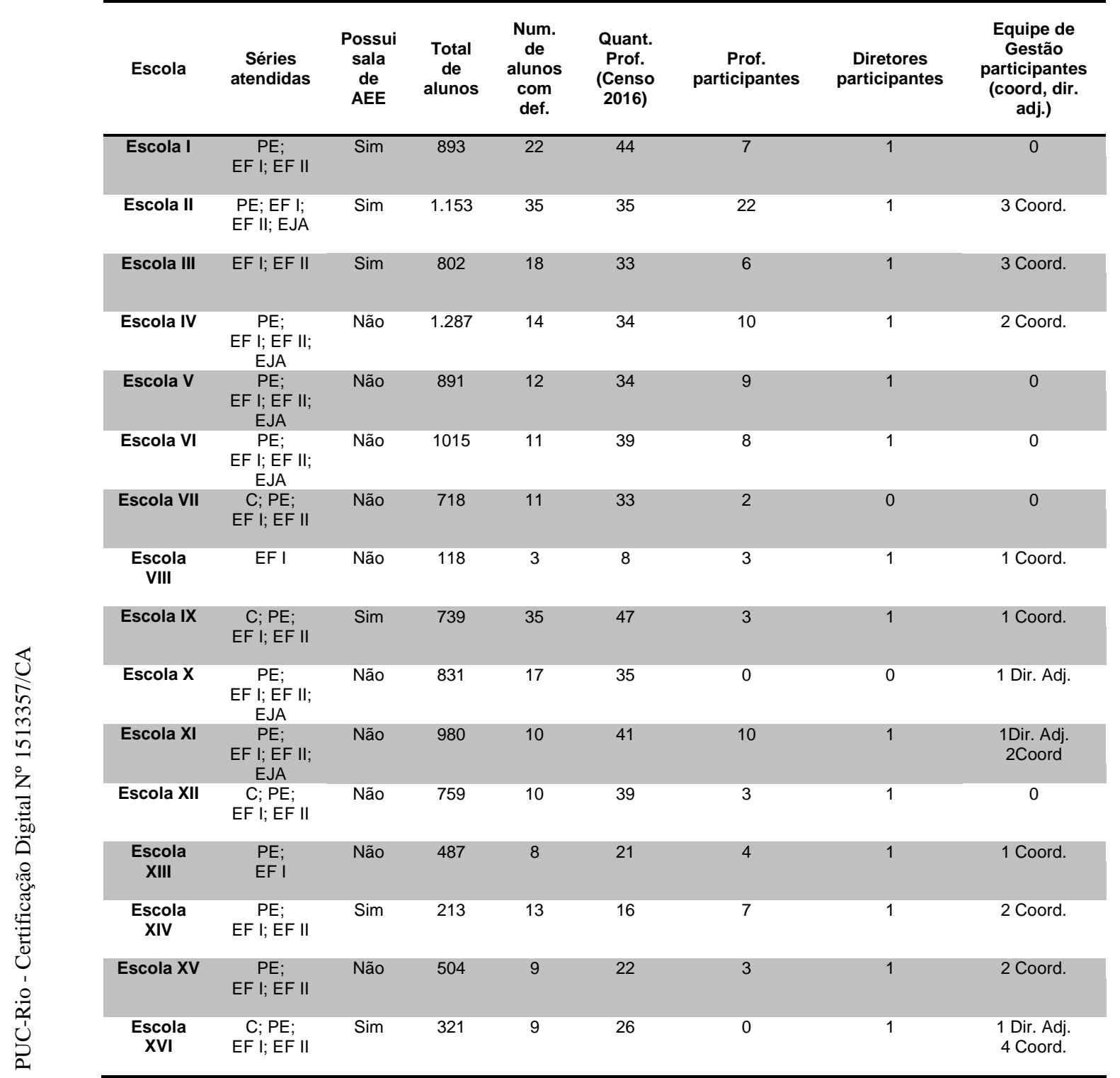

Legenda: C: Creche; EF: Ensino Fundamental; PE: Pré-escola; EJA: Educação de Jovens e Adultos. Fonte: Elaboração própria a partir dos dados do Censo Escolar 2016 e aplicação do survey GESQ Corumbá.

As escolas que mais tiveram participação dos professores na aplicação do survey foram as Escolas II, XIV e Escola VIII. No entanto, mesmo atendendo um dos critérios, não foram selecionadas para a segunda fase da pesquisa por serem escolas de tempo integral, o que impossibilitaria a comparação em relação à outra unidade escolar que funciona com regime de horário distinto. Quanto ao preenchimento dos questionários direcionados aos diretores não foram obtidas respostas apenas das Escolas VII e X. Em relação à equipe de gestão (coordenadores e diretores adjuntos) foi obtido retorno de 11 das 16 escolas 
participantes. Para que seja possível visualizar melhor os critérios de escolha das 3 escolas participantes da segunda fase da pesquisa, organizamos os dados de professores respondentes e alunos com deficiência em porcentagem, conforme a tabela a seguir. As escolas escolhidas aparecem em negrito.

Tabela 8: Quantidade de professores que responderam ao survey e quantidade de alunos com deficiência por escola em porcentagem.

\begin{tabular}{lcc}
\hline Escolas & $\begin{array}{c}\text { \% de professores } \\
\text { respondentes }\end{array}$ & \% de alunos com def. \\
\hline Escola I & 15,9 & 2,46 \\
\hline Escola II & $\mathbf{6 2 , 9}$ & $\mathbf{3 , 0 4}$ \\
\hline Escola III & 18,2 & 2,24 \\
\hline Escola IV & $\mathbf{2 9 , 4}$ & $\mathbf{1 , 0 9}$ \\
\hline Escola V & 26,5 & 1,35 \\
\hline Escola VI & $\mathbf{2 0 , 5}$ & $\mathbf{1 , 0 8}$ \\
\hline Escola VII & 6,1 & 1,53 \\
\hline Escola VIII & 37,5 & 2,54 \\
\hline Escola IX & $\mathbf{6 , 4}$ & $\mathbf{4 , 7 4}$ \\
\hline Escola X & 0,0 & 2,05 \\
\hline Escola XI & 24,4 & 1,02 \\
\hline Escola XII & 7,7 & 1,32 \\
\hline Escola XIII & 19,0 & $\mathbf{1 , 6 4}$ \\
\hline Escola XIV & 43,8 & 2,80 \\
\hline Escola XV & 0,0 & \\
\hline Escola XVI & 13,6 & 10 \\
\hline
\end{tabular}

Fonte: Elaboração própria a partir dos dados do Censo Escolar 2016.

Em relação à idade dos alunos, organizamos os dados por escola para sabermos quais das 16 escolas participantes da pesquisa apresentam maior número de estudantes fora da idade escolar obrigatória (de 4 a 17 anos), contrastando esse dado com os quantitativos de alunos com e sem deficiência. Os alunos considerados fora da idade escolar obrigatória são aqueles que possuem idade acima de 18 anos. 
Tabela 9: Alunos com e sem deficiência conforme instituição de ensino com idade entre 4 e 17 anos e acima de 18 anos.

\begin{tabular}{|c|c|c|c|c|c|c|c|c|c|}
\hline Escola & $\begin{array}{l}\text { Alunos } \\
\text { sem } \\
\text { deficiência } \\
\text { com idade } \\
\text { entre } 4 \text { a } \\
17 \text { anos }\end{array}$ & $\%$ & $\begin{array}{c}\text { Alunos } \\
\text { sem } \\
\text { deficiência } \\
\text { com } 18 \\
\text { anos ou } \\
\text { mais }\end{array}$ & $\%$ & $\begin{array}{l}\text { Alunos } \\
\text { com } \\
\text { deficiência } \\
\text { com idade } \\
\text { entre } 4 \text { e } \\
17 \text { anos }\end{array}$ & $\%$ & $\begin{array}{l}\text { Alunos } \\
\text { com } \\
\text { deficiência } \\
\text { com } 18 \\
\text { anos ou } \\
\text { mais }\end{array}$ & $\%$ & Total \\
\hline $\begin{array}{c}\text { Escola } \\
\text { I }\end{array}$ & 825 & 94,72 & 46 & 5,28 & 22 & 100 & 0 & - & 893 \\
\hline $\begin{array}{c}\text { Escola } \\
\text { II }\end{array}$ & 957 & 85,60 & 161 & 14,40 & 32 & 91,43 & 3 & 8,57 & 1.153 \\
\hline $\begin{array}{c}\text { Escola } \\
\text { III }\end{array}$ & 776 & 98,98 & 8 & 1,02 & 17 & 94,44 & 1 & 5,56 & 802 \\
\hline $\begin{array}{c}\text { Escola } \\
\text { IV }\end{array}$ & 1124 & 88,30 & 149 & 11,70 & 10 & 71,43 & 4 & 28,57 & 1.287 \\
\hline $\begin{array}{c}\text { Escola } \\
\text { V }\end{array}$ & 737 & 83,85 & 142 & 16,15 & 11 & 91,67 & 1 & 8,33 & 891 \\
\hline $\begin{array}{c}\text { Escola } \\
\text { VI }\end{array}$ & 954 & 91,38 & 50 & 4,79 & 8 & 88,89 & 1 & 11,11 & 1.015 \\
\hline $\begin{array}{c}\text { Escola } \\
\text { VII }\end{array}$ & 704 & 99,58 & 3 & 0,42 & 11 & 100 & 0 & - & 718 \\
\hline $\begin{array}{c}\text { Escola } \\
\text { VIII }\end{array}$ & 115 & 100 & 0 & - & 3 & 100 & 0 & - & 118 \\
\hline $\begin{array}{c}\text { Escola } \\
\text { IX }\end{array}$ & 605 & 85,94 & 99 & 14,06 & 32 & 91,43 & 3 & 8,57 & 739 \\
\hline $\begin{array}{c}\text { Escola } \\
X\end{array}$ & 633 & 77,76 & 181 & 22,24 & 8 & 47,06 & 9 & 52,94 & 831 \\
\hline $\begin{array}{c}\text { Escola } \\
\text { XI }\end{array}$ & 903 & 93,09 & 67 & 6,91 & 10 & 100 & 0 & - & 980 \\
\hline $\begin{array}{c}\text { Escola } \\
\text { XII }\end{array}$ & 683 & 91,19 & 66 & 8,81 & 9 & 90,00 & 1 & 10,00 & 759 \\
\hline $\begin{array}{c}\text { Escola } \\
\text { XIII }\end{array}$ & 479 & 100 & 0 & - & 7 & 87,50 & 1 & 12,50 & 487 \\
\hline $\begin{array}{c}\text { Escola } \\
\text { XIV }\end{array}$ & 200 & 100 & 0 & - & 13 & 100 & 0 & - & 213 \\
\hline $\begin{array}{c}\text { Escola } \\
\text { XV }\end{array}$ & 490 & 98,99 & 5 & 1,01 & 9 & 100 & 0 & - & 504 \\
\hline $\begin{array}{c}\text { Escola } \\
\text { XVI }\end{array}$ & 311 & 99,68 & 1 & 0,32 & 9 & 100 & 0 & - & 321 \\
\hline
\end{tabular}

A partir da tabela 5 podemos verificar que algumas escolas apresentam grande número de alunos com defasagem idade/série, independente de possuírem alguma deficiência. Dentre elas destacamos as Escolas II, IV, V, IX e X. Importante ressaltar que das escolas com grande número de alunos com deficiência acima de 18 anos, ou seja, fora da idade de escolarização obrigatória, temos as escolas que ofertam a modalidade de Educação de Jovens e Adultos.

Sobre a etapa de ensino, a tabela a seguir mostra as séries frequentadas pelos estudantes com deficiência na rede municipal de ensino de Corumbá. Considerando que as escolas com alto número de alunos com deficiência ofertam a modalidade de Educação de Jovens e Adultos, fez-se necessário organizar os dados de acordo com a etapa de ensino para que fosse possível verificar quais escolas possuem mais alunos com deficiência nos anos iniciais e finais do Ensino 
Fundamental, foco principal do presente estudo. Assim, a tabela a seguir mostra a quantidade de alunos com deficiência, conforme a etapa de ensino, por escola.

Tabela 10: Alunos com deficiência matriculados na educação infantil, anos iniciais e finais do ensino fundamental e EJA das escolas participantes da pesquisa.

\begin{tabular}{ccccccccc}
\hline $\begin{array}{l}\text { Escolas } \\
\text { respondentes }\end{array}$ & $\begin{array}{c}\text { Alunos } \\
\text { com } \\
\text { Def. na } \\
\text { Ed. Inf. }\end{array}$ & $\begin{array}{c}\text { Alunos } \\
\text { com } \\
\text { Def. EF } \\
\text { I }\end{array}$ & $\begin{array}{c}\text { Alunos } \\
\text { com } \\
\text { Def.EF } \\
\text { II }\end{array}$ & $\begin{array}{c}\text { Alunos } \\
\text { com } \\
\text { Def. } \\
\text { EJA- } \\
\text { EF I }\end{array}$ & $\begin{array}{c}\text { Alunos } \\
\text { com } \\
\text { Def. } \\
\text { EJA- } \\
\text { EF II }\end{array}$ & $\begin{array}{c}\text { Alunos } \\
\text { com Def. } \\
\text { no EJA- } \\
\text { EF } \\
\text { Projovem } \\
\text { Urbano }\end{array}$ & $\begin{array}{c}\text { Sem } \\
\text { dados } \\
\text { de } \\
\text { etapa } \\
\text { de } \\
\text { ensino }\end{array}$ & Total \\
\hline Escola I & 2 & 10 & 8 & 0 & 0 & 0 & 2 & $\mathbf{2 2}$ \\
\hline Escola II & $\mathbf{0}$ & $\mathbf{2 0}$ & $\mathbf{9}$ & $\mathbf{3}$ & $\mathbf{3}$ & $\mathbf{0}$ & $\mathbf{0}$ & $\mathbf{3 5}$ \\
\hline Escola III & 0 & 8 & 4 & 0 & 0 & 0 & 6 & $\mathbf{1 8}$ \\
\hline Escola IV & $\mathbf{0}$ & $\mathbf{7}$ & $\mathbf{2}$ & $\mathbf{4}$ & $\mathbf{1}$ & $\mathbf{0}$ & $\mathbf{0}$ & $\mathbf{1 4}$ \\
\hline Escola V & 0 & 10 & 1 & 0 & 0 & 1 & 0 & $\mathbf{1 2}$ \\
\hline Escola VI & 0 & 5 & 4 & 0 & 2 & 0 & 0 & $\mathbf{1 1}$ \\
\hline Escola VII & 0 & 8 & 3 & 0 & 0 & 0 & 0 & $\mathbf{1 1}$ \\
\hline Escola VIII & 0 & 3 & 0 & 0 & 0 & 0 & 0 & $\mathbf{3}$ \\
\hline Escola IX & $\mathbf{2}$ & $\mathbf{1 4}$ & $\mathbf{1}$ & $\mathbf{0}$ & $\mathbf{0}$ & $\mathbf{0}$ & $\mathbf{1 8}$ & $\mathbf{3 5}$ \\
\hline Escola X & 0 & 5 & 4 & 8 & 0 & 0 & 0 & $\mathbf{1 7}$ \\
\hline Escola XI & 0 & 8 & 2 & 0 & 0 & 0 & 0 & $\mathbf{1 0}$ \\
\hline Escola XII & 0 & 4 & 6 & 0 & 0 & 0 & 0 & $\mathbf{1 0}$ \\
\hline Escola XIII & 1 & 6 & 1 & 0 & 0 & 0 & 0 & $\mathbf{8}$ \\
\hline Escola XIV & 0 & 5 & 8 & 0 & 0 & 0 & 0 & $\mathbf{1 3}$ \\
\hline Escola XV & 2 & 5 & 2 & 0 & 0 & 0 & 0 & $\mathbf{9}$ \\
\hline Escola XVI & 0 & 4 & 5 & 0 & 0 & 0 & 0 & $\mathbf{9}$ \\
\hline Total & $\mathbf{7}$ & $\mathbf{1 2 2}$ & $\mathbf{6 0}$ & $\mathbf{1 5}$ & $\mathbf{6}$ & $\mathbf{1}$ & $\mathbf{2 6}$ & $\mathbf{2 3 7}$ \\
\hline
\end{tabular}

Fonte: Elaboração própria a partir dos dados do Censo Escolar 2016.

Vale ressaltar que algumas escolas não apresentaram informações a respeito da etapa de ensino de alguns estudantes com deficiência, não sendo possível saber em qual ano/série 10,9\% dos alunos se encontram. Desses 26 alunos sem informação de etapa de ensino, 18 estão matriculados na Escola IX, seis deles estão na Escola III e II na Escola I. Acreditamos que a ausência de informação a respeito da etapa de ensino aconteça possivelmente, devido à dupla matrícula dos alunos nas escolas que possuem atendimento educacional especializado. Conforme apresentado no capítulo I do presente trabalho, a Resolução CNE/CEB n. ${ }^{\circ} 04 / 2009$ prevê que "o financiamento da matrícula do AEE é condicionado à matrícula na rede regular de ensino, conforme registro no Censo Escolar do ano anterior. O Decreto 7.611/2011 enfatiza que a matrícula dupla possui como objetivo estimular o acesso ao atendimento educacional especializado (Brasil, 2011). 
Portanto, escolhemos para participar da segunda fase da pesquisa a Escola II, Escola IV e Escola IX. A escolha da Escola II e da Escola IX ocorreu devido à grande quantidade de alunos com deficiência matriculados e que frequentam o ensino fundamental. O segundo critério foi a quantidade de professores que responderam ao Survey-GESQ 2017, com o objetivo de possuirmos um panorama geral da escola, a partir do questionário, auxiliando na escolha da unidade para realização da fase empírica da pesquisa. A Escola IX em especial, foi selecionada devido ao seu histórico na educação de pessoas com deficiência no município de Corumbá. Já a Escola IV foi escolhida devido à quantidade de alunos com deficiência matriculados e ausência de uma sala de recursos multifuncional. Os critérios tiveram como objetivo investigar diferentes contextos organizacionais de implementação das políticas: unidades que tinham a sala de recursos e unidades que não contam com esse espaço. A Escola IV também não conta com nenhum profissional de apoio na escola, o que identificamos como um contexto diferenciado de implementação em relação às outras duas unidades. O próximo item apresenta as três unidades escolares de forma mais detalhada.

\section{2. \\ A pesquisa empírica: observações e entrevistas nas três unidades escolares}

Durante os meses de junho a setembro de 2018 foram realizadas observações e entrevistas nas três unidades escolares, com tempo aproximado de 30 dias de permanência em cada uma delas, durante todo o horário letivo. Durante esse período foram feitas observações em sala de aula, incluindo aulas de educação física, acompanhamento da rotina da gestão escolar, da dinâmica da sala dos professores, do funcionamento da sala de recursos multifuncionais e realização das entrevistas.

Das três unidades escolares escolhidas, uma está localizada próxima à área central (zona norte) da cidade e as outras duas na parte alta (zona sul). A cidade é popularmente dividida em parte alta e parte baixa: na parte alta estão localizados os bairros mais pobres do município, tendo como principal característica de expansão a construção de conjuntos habitacionais e implantação de loteamentos populares (PEREIRA, 2007). 
Com o intuito de melhor visualizarmos as três unidades escolares participantes da segunda fase da pesquisa, apresentamos a tabela a seguir:

Tabela 11: Quantidade total de alunos e quantidade de alunos com deficiência das três escolas selecionadas para a segunda fase da pesquisa.

Unidades escolares
Quantidade de alunos com deficiência

\begin{tabular}{ccc}
\hline Escola II & 1.153 & 35 \\
Escola IV & 1.287 & 14 \\
Escola IX & 739 & 35 \\
\hline
\end{tabular}

Fonte: Survey GESQ-Corumbá, 2017.

A apresentação de cada uma das unidades escolares será realizada de maneira individual. Começaremos pelas duas escolas que possuem sala de recursos multifuncionais e profissionais de apoio (Escolas II e IX) e por último, apresentaremos a Escola IV, que não conta com nenhum desses recursos voltados aos alunos com deficiência.

4.2.1.

A Escola II

A Escola II é a segunda escola da rede com maior número de alunos matriculados. A unidade escolar oferta Educação Infantil, Ensino Fundamental e EJA, funcionando nos períodos matutino, vespertino e noturno. Localizada na parte alta da cidade, a escola funciona no segundo bairro mais populoso da cidade, que conta com uma estimativa de 10.454 habitantes de acordo com o Censo Demográfico 2010, sendo um dos maiores em extensão territorial. O bairro apresenta pouca estrutura contando apenas com uma escola municipal e uma escola estadual.

A escola conta com 17 salas de aulas que comportam os 1.153 estudantes matriculados. Não possui quadra esportiva, sendo necessário que os alunos pratiquem as atividades físicas na praça localizada ao lado da escola. A escola possui um pátio coberto utilizado para recreação, reuniões e eventos, não possui refeitório (os alunos consomem a merenda dentro da sala de aula) e conta com um laboratório de informática. Não possui biblioteca, nem sala de leitura. 
Classificada pela Secretaria Municipal de Educação como uma unidade escolar de tipologia A, a escola conta com uma equipe de gestão composta por 1 diretora administrativa, 1 diretora adjunta e 2 coordenadoras $^{78}$, sendo uma coordenação responsável pela educação infantil e anos iniciais do ensino fundamental e outra pelos anos finais do ensino fundamental e EJA.

Participaram da entrevista a coordenadora da educação infantil e anos iniciais do ensino fundamental, a diretora adjunta e a diretora administrativa, além de dois professores regentes, a professora do AEE e uma profissional de apoio.

A diretora administrativa é professora licenciada e atua como professora há 25 anos. Há 10 anos responde pela direção da Escola II, sendo eleita pela comunidade escolar pela terceira vez no ano de 2018. A diretora é a responsável pelo gerenciamento dos recursos da unidade. Durante a entrevista, a ela afirma que esta é sua função principal, porém não é possível desvincular sua atuação das funções pedagógicas, pois necessita ter informações relacionadas a todo o funcionamento da unidade.

A diretora adjunta iniciou seus trabalhos na Escola II no mês de setembro de 2018, período de realização das observações e entrevistas. Ela afirma que atuou anteriormente, como gestora em uma unidade escolar da zona rural e que já fez parte da equipe da secretaria municipal de educação, porém não informou o período e o tempo em que atuou. A diretora adjunta possui formação em Pedagogia e atua na rede municipal já 15 anos. Quanto à sua atuação como diretora adjunta da Escola II ela afirma que pretende atuar de maneira conjunta e que sua primeira atividade como gestora da parte pedagógica foi verificar se os alunos dos anos iniciais do ensino fundamental estavam sendo alfabetizados, averiguando isso de maneira individual.

As coordenadoras possuem formação em Pedagogia. A coordenação da educação infantil e anos iniciais do ensino fundamental, que participou da entrevista, está há 25 anos na Escola II e atua na coordenação há 5 anos. Ela informa que antes de assumir a coordenação, era professora regente da educação infantil e da EJA. Quanto à sua atuação ela informa que atua diretamente com os

\footnotetext{
${ }^{78}$ Uma das coordenadoras encontra-se afastada por motivos de saúde.
} 
professores, alunos e famílias. Em relação aos professores, a coordenadora informa que auxilia nas atividades e disponibiliza materiais de apoio. A respeito dos alunos, ela afirma que sua maior atuação é relacionada aos aspectos comportamentais. Nos casos em que o aluno apresenta mau comportamento, ele é encaminhado para uma "conversa" com a coordenadora, que dependendo do caso, solicita a presença da família. Ela afirma que realiza muitos atendimentos de responsáveis de alunos, que são chamados ou buscam a escola para resolver situações diversas (dúvidas quanto às notas, queixas relacionadas a alguma situação ocorrida dentro da escola, brigas entre alunos, entre outros).

A equipe de gestão possui apenas uma sala, onde as quatro agentes dividem um pequeno espaço e contam com apenas um computador, utilizado de forma compartilhada. A sala dos professores fica situada como uma "antessala" do espaço ocupado pela equipe de gestão e conta com uma mesa grande, onde os professores permanecem durante os horários que não estão em sala de aula. A sala dos professores conta com 2 computadores, compartilhados entre os 35 professores que atuam na unidade.

A escola conta também com uma sala de recursos multifuncional, onde é ofertado o atendimento educacional especializado nos períodos matutino e vespertino. A sala de recurso da escola é categorizada como tipo I. A professora do AEE possui formação em Pedagogia e atuava na escola há um ano (desde o início do período letivo de 2017) e anteriormente atuava como professora do AEE na cidade de Ladário/MS. Ela conta que recebeu convite para atuar na rede municipal de Corumbá devido à sua atuação próxima às famílias dos alunos. A docente possui vínculo temporário de trabalho.

Já a profissional de apoio entrevistada atuava na Escola II desde o início do segundo semestre de 2018. A entrevistada afirma que atuou anteriormente na rede municipal de Corumbá como professora contratada ministrando aulas da disciplina de Artes. Ela informa que está atuando como profissional de apoio porque tem uma especialização na área de Atendimento Educacional Especializado. Seu vínculo de trabalho atual é temporário. Quando à sua atuação, afirma que é responsável pelo acompanhamento de uma aluna que possui 
Síndrome de Asperger ${ }^{79}$ que frequenta o segundo ano do ensino fundamental. A aluna está sendo alfabetizada e têm demonstrado um bom desempenho, de acordo com a entrevistada. A professora da turma é a professora regente I, que também participou da entrevista de maneira individual.

Em relação aos professores regentes, participaram da entrevista: uma professora do segundo ano (professora regente I) e um professor do quarto ano (professor regente II). A professora regente I atuava na escola há um mês (desde o segundo semestre de 2018). Ela conta que começou a trabalhar na Escola II após ser chamada no concurso público, porém, foi professora contratada da rede municipal por 8 anos. Sua experiência anterior foi em uma instituição privada de caráter filantrópico onde atuou por 7 anos, trabalhando exclusivamente com alunos que possuíam diagnóstico de deficiência intelectual e deficiência múltipla.

Por fim, o professor regente II trabalha na escola há 42 anos, desde que iniciou sua carreira docente no ano de 1976. Conta que formou-se inicialmente no magistério, quando iniciou sua carreira na alfabetização de adultos. Posteriormente, em 1996 formou-se em Pedagogia e continuou atuando no Ensino Fundamental e EJA. O professor informa que possui na turma uma profissional de apoio que acompanha uma aluna que tem diagnóstico de doença mental. Ele informa que não sabe ao certo o que a aluna tem e conta que quem realiza todas as atividades com ela é a profissional de apoio.

Durante as observações do campo foi possível verificar que a escola enfrenta diversas dificuldades relacionadas às questões financeiras. Frequentemente, os professores e a gestão da unidade organizam festivais de prêmios, rifas, sorteios e comercializavam alimentos (como uma espécie de cantina e também oferecendo os itens aos alunos nas sala de aula). Nas entrevistas, a equipe de gestão informou que a prática é corriqueira, uma vez que a escola não possui recursos suficientes para realização de manutenção do espaço

\footnotetext{
${ }^{79}$ A síndrome de Asperger (SA) caracteriza-se por prejuízos na interação social, bem como interesses e comportamentos limitados, como foi visto no autismo, mas seu curso de desenvolvimento precoce está marcado por uma falta de qualquer retardo clinicamente significativo na linguagem falada ou na percepção da linguagem, no desenvolvimento cognitivo, nas habilidades de autocuidado e na curiosidade sobre o ambiente. (KLIN, 2006 p. 8).
} 
físico e dos equipamentos utilizados. A diretora administrativa afirma que o repasse de recursos não é suficiente, que a escola está sem reforma, necessitando de constantes reparos.

Foram observadas 6 turmas, sendo que apenas uma delas contava com o profissional de apoio. As turmas não contavam com redução do número de alunos, mesmo possuindo alunos com deficiência matriculados. Durante as entrevistas, a coordenadora afirma que a escola não tem condições de cumprir a legislação municipal de redução de alunos, pois a unidade escolar encontra-se em sua lotação máxima.

Durante as observações do campo, foi possível perceber a dificuldade da lotação das salas. Não existem mesas e cadeiras suficientes em algumas salas de aula, sendo necessária a busca por tais mobiliários em toda a escola. Tanto no período matutino (Ensino Fundamental I), quanto no vespertino (Ensino Fundamental II), observou-se que os alunos saem pela escola procurando mesas e cadeiras em salas que apresentaram alguma ausência de estudantes. Essa situação foi vista em todos os dias de observação nesta unidade. Em um determinado dia, no período matutino, a professora do segundo ano se preocupa com a quantidade de alunos presentes e lamenta: "Poxa! Hoje vieram todos!" (professora regente I) Enquanto isso, a profissional de apoio percorre toda a escola para conseguir mesas e cadeiras para os alunos que estão em pé. A sala está muito cheia e nas fileiras não cabem mais alunos, sendo necessário pedir para que eles se posicionem mais à frente, para que seja possível encaixar os alunos nos mínimos espaços restantes. Toda essa organização toma, pelo menos 30 minutos da aula.

Sobre essa situação, a coordenadora afirma que a diretora administrativa já solicitou à secretaria a reforma das mesas e cadeiras que não apresentam condições mínimas de uso, no entanto, diante da ausência de recursos públicos, elas utilizam o dinheiro das rifas, festivais de prêmios e outras ações para tentar resolver problemas como esses. Caso não consigam o valor, utilizam recursos próprios.

O trabalho do gestor escolar reflete as dificuldades existentes no contexto da educação brasileira, no entanto, a ele é atribuída a responsabilidade em relação aos resultados das unidades escolares. Formalmente sua figura está ligada à 
autonomia, no entanto, as condições existentes mostram que sua realidade é bem diferente. Oliveira, Vieira e Augusto (2014) afirmam que a natureza e o desenvolvimento do trabalho do diretor escolar apresentam-se de forma contraditória com sua condição de trabalhador. Esta situação tem sido fonte de tensões no exercício da gestão escolar na educação básica. A descentralização da educação é um dos fatores que mais impactaram na atuação do diretor escolar. A atuação da equipe de gestão acaba voltando-se para o atendimento das necessidades básicas da instituição de ensino, priorizando questões ligadas ao funcionamento mínimo da unidade. As gestoras da unidade escolar preocupam-se com situações ligadas à quantidade de mesas e cadeiras por sala de aula, aspectos infraestruturais que garantem o funcionamento da escola.

As observações e as entrevistas realizadas na Escola II apontam para uma situação de precariedade contribui para que esses atores priorizem aspectos básicos com a finalidade de garantir o funcionamento da escola.

\subsection{2.}

\section{A Escola IX}

A Escola IX localiza-se em um bairro na parte baixa da cidade, que possui aproximadamente 4.200 habitantes, conforme o Censo Populacional 2010 e contém uma escola municipal e uma escola estadual. A unidade escolar possuía no ano de 2016, 739 alunos matriculados, de acordo com os dados do Censo Escolar. A unidade escolar possui tipologia A e oferta Educação Infantil, Ensino Fundamental, EJA e possui dentro de sua estrutura uma creche ${ }^{80}$. Sua equipe de gestão conta com 1 diretora administrativa, 1 diretora adjunta, 3 coordenadoras (uma responsável pelos anos iniciais do ensino fundamental, uma pelos anos finais do ensino fundamental e outra pela EJA). É a escola que possui maior número de salas de recursos multifuncional: 5 no total, sendo uma destinada exclusivamente para o atendimento de alunos com deficiência auditiva ou surdez e 2 voltadas ao atendimento de alunos com deficiência visual ou cegueira. $\mathrm{Na}$ Escola IX são atendidos alunos com deficiência de várias outras unidades

\footnotetext{
${ }^{80}$ A creche possui coordenação própria.
} 
escolares, que se utilizam do transporte ofertado pela rede municipal de ensino para frequentar o AEE.

Participaram da entrevista a diretora administrativa, 2 coordenadoras (responsável pelos anos iniciais do ensino fundamental ${ }^{81}$ e responsável pelos anos finais do ensino fundamental ${ }^{82}$, respectivamente), 2 professoras regentes ${ }^{83}$, uma profissional de apoio e 2 professoras do $\mathrm{AEE}^{84}$.

A escola conta com 24 salas de aulas, sala de professores, sala de coordenação, sala da direção administrativa, quadra coberta, refeitório, biblioteca, auditório, sala de leitura, laboratório de informática e laboratório de ciências.

A diretora administrativa possui Licenciatura e atua na rede municipal há 10 anos, como professora de Artes e no período da realização da entrevista respondia pela direção da escola há 3 meses. A entrevistada conta que a direção é uma experiência nova e que ainda está aprendendo sobre todos os procedimentos. Afirma que possui apoio da secretaria nos casos em que tem dúvidas, principalmente em relação às prestações de contas e recursos financeiros. Segundo ela, a secretaria disponibilizou um profissional da área de Ciências Contábeis para sanar as dúvidas da diretora durante seus primeiros meses de atuação.

A coordenadora I possui formação em Pedagogia e no período de realização da entrevista atuava na escola há 19 anos, desde o ano de 1999. Sempre respondeu pela coordenação dos anos iniciais do ensino fundamental, pois realizou concurso para Especialista em Educação ${ }^{85}$. Antes da coordenação trabalhou em uma escola da rede estadual dando aulas para turmas do $1^{\circ}$ ao $5^{\circ}$ ano do ensino fundamental por 16 anos. Ela afirma que atua diretamente com os professores, atendendo na parte pedagógica, questões relacionadas à atividades avaliativas, orientações quanto à didática e metodologia, acompanhamentos das notas e frequências por meio dos diários de classe e Conselhos de Classe. A coordenadora afirma que também realiza um trabalho com os alunos, com o

\footnotetext{
${ }^{81}$ A quem iremos nos referir como coordenadora I.

${ }^{82}$ A quem iremos nos referir como Coordenadora II.

${ }^{83}$ A quem iremos nos referir como Professora Regente I e Professora Regente II.

${ }^{84}$ A quem iremos nos referir como Professora do AEE I e Professora do AEE II.

${ }^{85}$ O Plano de Cargos e Carreiras da Prefeitura Municipal de Corumbá prevê a vaga de Especialista em Educação, profissional que atua na rede municipal de ensino através da função de Coordenador Pedagógico, Inspetor Escolar ou Gestor de Administração Escolar (Corumbá, 2005).
} 
objetivo de verificar se estão alfabetizados (realiza leitura de textos e ditados). Em relação aos alunos ela afirma que atua principalmente em questões relacionadas à disciplina. Nesses casos, solicita a presença da família para relato dos casos. A família também é chamada nos casos em que o aluno apresenta dificuldades de rendimento.

A coordenadora II possui Licenciatura e atua na escola há 14 anos, sendo 3 na coordenação e 11 em sala de aula. É responsável pelas turmas do $6^{\circ}$ ao $9^{\circ}$ ano desde 2015, quando assumiu a coordenação a convite da diretora que atuava na época. A entrevistada descreve como suas principais atividades orientação aos professores em relação a metodologias e didática, controle das notas e frequência por meio do acompanhamento dos diários de classe (nos casos em que o aluno apresenta muitas faltas, ela afirma que entra em contato com a família), disponibilização de materiais didáticos, auxílio em atividades extraclasse e atendimento à família de alunos.

A professora regente I atua na Escola IX desde o ano de 2015 como professora contratada. Afirma que começou a trabalhar na escola logo após terminar sua graduação em Pedagogia (no ano de 2014), atuando na pré-escola e posteriormente com o $1^{\circ}$ e $2^{\circ}$ ano do ensino fundamental. No período de realização da entrevista ela afirmou que estava atuando com uma turma de $2^{\circ}$ ano que possui um aluno com Síndrome de Down. Ela diz que é a primeira vez que ela trabalha com um aluno com deficiência. A professora informa que o aluno não conta com profissional de apoio, pois possui independência quanto às atividades de vida diária. Quanto à necessidade de orientações para realização das atividades realizadas com o aluno com deficiência, ela enfatiza que sempre conta com o apoio do CMADIJ, que frequentemente está na escola.

A professora regente II possui formação em Pedagogia e atuava na escola desde o segundo semestre de 2018. Ela afirma que possui experiência de 10 anos na educação especial, pois já trabalhou como profissional de apoio na rede municipal da cidade em que residia anteriormente. No período da entrevista atuava como regente de uma turma do $2^{\circ}$ ano do ensino fundamental que possuía dois alunos com Síndrome de Down (um com 8 anos e outro com 18 anos). Os 
alunos contam com uma profissional de apoio, que também participou da entrevista de maneira individual.

A profissional de apoio possui formação em Pedagogia e atua na escola desde o início do ano letivo de 2018. Ela afirma que já trabalhou como professora contratada em outras duas escolas da rede municipal. Está na rede há 3 anos. A respeito de sua atuação, ela conta que trabalha com os dois alunos que tem Síndrome de Down, sendo um deles dependente de auxílio nas atividades de vida diária. Afirma que ajuda na adaptação dos materiais destinados aos dois alunos e em relação à organização das atividades dentro e fora da sala de aula. Ambos alunos não são alfabetizados.

Quanto às profissionais do AEE, entrevistamos inicialmente a Professora do AEE I que possui formação em Pedagogia e trabalhou na Escola IX no ano de 2016, como profissional de apoio e em 2018 como professora do AEE. No ano de 2017 trabalhou em outra escola da rede municipal, também como professora do AEE. Possui experiência na educação especial devido sua atuação como professora em uma instituição privada de caráter filantrópico, onde atuou no período de 2009 a 2016.

A professora do AEE II atua especificamente com alunos com deficiência auditiva e surdez. Possui formação em Pedagogia e atua na escola desde o ano de 2017. Possui experiência de nove anos na educação especial como Intérprete da Língua Brasileira de Sinais (LIBRAS).

Foram observadas 7 turmas e 2 delas contavam com o profissional de apoio (a primeira que acompanhava uma aluna com Paralisia Cerebral e a segunda que acompanhava os dois alunos com Síndrome de Down). Em algumas turmas foram feitas observações por mais de uma vez, a exemplo da sala de $2^{\circ}$ ano dos alunos com Síndrome de Down. As turmas observadas contavam com poucos alunos (uma média de 18, por sala). O fato ocorre devido aos alunos com deficiência matriculados indicando que a escola segue a legislação municipal que prevê a diminuição de alunos nas turmas que possuírem um aluno com deficiência.

$\mathrm{Na}$ Escola IX também observamos a realização de festival de prêmios, porém com menor ocorrência que na Escola II. A prática aparenta ser comum nas 
escolas da rede municipal, pois durante a primeira fase da pesquisa isso também foi visto em outras unidades escolares ${ }^{86}$

4.2.3.

A Escola IV

A Escola IV é a unidade que possui maior número de matrículas, conforme o Censo Escolar 2016. Está localizada no bairro com maior extensão territorial do município, que possui cerca de 8 mil habitantes, conforme os dados do Censo Populacional 2010. O bairro contém vários conjuntos habitacionais e loteamentos populares, possuindo 3 escolas municipais e 1 escola estadual.

Classificada pela secretaria como uma escola de Tipologia A, a unidade escolar IX conta com um diretor administrativo, uma diretora adjunta, seis coordenadores que atuam com carga horária de 20h (três no período matutino e três no período vespertino). A escola oferta Educação Infantil, Ensino Fundamental (I e II) e EJA. Possuíam 1.176 alunos matriculados conforme os dados do Censo 2016.

A unidade escolar possui em sua estrutura 19 salas de aula, laboratório de informática, sala de direção administrativa, sala de coordenação, sala de professores, quadra de esporte coberta, biblioteca (utilizada também como sala de professores), auditório, e pátio coberto.

Esta escola contou com um número menor de entrevistas realizadas, sendo possível apenas entrevistar o diretor administrativo, um coordenador e uma professora regente. A diferenciação também ocorreu porque a escola não conta com sala de recursos multifuncional e com nenhum profissional de apoio. Foram realizadas tentativas de entrevistas com mais dois professores regentes e com uma coordenadora, no entanto, eles não apresentaram disponibilidade para participar.

O diretor administrativo possui formação em Educação Física e responde pela direção desde o segundo semestre de 2018. No período de realização da entrevista ele ocupava o cargo de diretor há dois meses e relatou estar na escola há 20 anos, desde 1998 no período matutino e desde 2004 no período matutino e

\footnotetext{
${ }^{86} \mathrm{Em}$ uma delas a diretora contou que realiza frequentemente promoções, festival de prêmios e rifas com o objetivo de pagar dívidas que a escola possui em determinada papelaria da cidade e também que utilizou o dinheiro para pintar a escola.
} 
vespertino atuando com turmas dos anos iniciais do ensino fundamental. Ele afirma que sua atuação como diretor é relacionada à parte administrativa da escola e que a diretora adjunta é responsável pela parte pedagógica, no entanto ele enfatiza que as decisões são tomadas em conjunto, pois ele necessita ter conhecimento de todas as atividades realizadas.

O coordenador possui Licenciatura com 18 anos de experiência, atuando na Escola IV desde 2010. Há quatro anos responde pela coordenação da escola, sendo responsável pelos segundos e terceiros anos do período vespertino. Nesta unidade escolar observamos que a organização das coordenações é diferente, pois o profissional relata que é responsável apenas por algumas turmas. Com carga horária de 20 horas, ele também atua nas outras 20 horas, como professor do ensino médio na rede estadual de ensino. Quanto às suas atribuições, ele afirma que acompanha as notas e frequências dos alunos por meio dos diários de classe, realiza orientações pedagógicas aos docentes, oferece material didático, atende também os responsáveis dos alunos, principalmente em casos em que os estudantes apresentam comportamentos considerados indisciplinados.

A professora regente entrevistada possui formação em Pedagogia e trabalha na escola há 3 anos como professora contratada. Atua em uma sala de $2^{\circ}$ ano do ensino fundamental. Não possui experiência anterior, pois se formou no ano de 2014. Trabalha também como professora regente em uma escola da rede estadual. A turma do $2^{\circ}$ ano possui dois alunos, ambos com 8 anos de idade, que ela acredita que tenham deficiência, porém os alunos nunca passaram por nenhuma avaliação. A professora afirma que existe a suspeita de que uma aluna tenha deficiência auditiva. Já o outro aluno, de acordo com a professora, aparenta ter deficiência intelectual.

Em relação à aluna a professora relata existir uma série de suspeitas quanto a um possível diagnóstico. Inicialmente, acreditavam que ela possuía Transtorno de Atenção. A professora conta que a aluna passou por consulta médica e fez uso de Ritalina, porém isso ocorreu em período anterior ao ano letivo de 2018. A história foi relatada para a professora pela coordenação da escola. A suspeita de diagnóstico foi alterada posteriormente, pois a aluna não interagia com os colegas. Diante disso, a suspeita passou a ser relacionada a um possível caso de Autismo. 
Porém, no segundo semestre de 2018, a secretaria municipal de educação passou a contar com uma fonoaudióloga em seu quadro de servidores. Durante visita à Escola IV, a fonoaudióloga informou à escola que a aluna aparenta ter deficiência auditiva, orientando a escola quanto ao encaminhamento da aluna para avaliação.

Já o aluno que a professora acredita ter deficiência intelectual está temporariamente em uma Casa de Acolhimento, pois foi retirado do âmbito familiar por suspeita de maus tratos. Durante as observações do campo, foi possível perceber que o aluno requer constante atenção da professora, solicitando auxílio em todas as atividades realizadas.

Em uma outra turma observada existe um aluno que está frequentando o segundo ano pela quarta vez. Com idade de 12 anos, ele apresenta muitas dificuldades em acompanhar os conteúdos ministrados. $\mathrm{O}$ caso deste aluno foi relatado logo no primeiro contato com esta unidade escolar. O coordenador informou que ele está na mesma turma há quatro anos e que a escola não sabe o que fazer nessa situação. A professora do aluno informou que ele não consegue contar de 0 a 10 e que frequenta o atendimento educacional especializado em outra unidade escolar próxima, mas que ela não tem nenhuma informação sobre esses atendimentos. Durante a entrevista com o coordenador, ele ressalta que o aluno não frequenta o $\mathrm{AEE}$, pois a família não o leva para os atendimentos. Dessa forma, ele orientou a família a realizar a matrícula do aluno na instituição privada de caráter filantrópico, mas segundo ele, a orientação não foi seguida. Como o presente trabalho não teve como objetivo o contato com a família, os motivos que levam a esta situação no que se refere ao âmbito familiar não puderam ser verificados.

As observações foram feitas em três turmas, sendo realizadas mais de uma vez em uma delas. As turmas não contam com redução no número de alunos matriculados, devido à ausência de diagnóstico dos alunos com suspeita de deficiência, de acordo com o coordenador. A quantidade de alunos nas turmas observadas era de 20 estudantes, em média. O coordenador afirma que para ter redução no número de alunos é necessário que exista o laudo. A solicitação de um profissional de apoio também é vinculada à necessidade de laudo. Esta é uma diretriz da política municipal. 
A partir da descrição das escolas que participaram da segunda fase da pesquisa, no próximo item, abordaremos as percepções dos agentes em relação à deficiência e ao conceito de educação inclusiva para então empreendermos as discussões sobre os agentes implementadores que atuam nas unidades escolares.

\section{3. \\ As percepções sobre a deficiência: como as pessoas com deficiência são enxergadas pelos implementadores das políticas públicas.}

A percepção dos agentes em relação aos alunos com deficiência foram aspectos primordiais para o entendimento sobre a implementação da política da educação especial. Durante as observações do campo e realização das entrevistas verificamos como os agentes implementadores (tanto no âmbito da secretaria municipal de educação, quanto das escolas) percebem a deficiência e a inserção dos alunos com deficiência na escola regular. Partimos do conceito de capacitismo para analisarmos tais percepções.

Conforme já abordado no presente trabalho, o capacitismo define a forma como as pessoas com deficiência são tratadas de modo generalizado como incapazes (de produzir, de trabalhar, de aprender, de cuidar, dentre outros aspectos), aproximando as demandas dos movimentos de pessoas com deficiência a outras discriminações sociais. A postura discriminatória contribui para que não seja considerado o fato de que as pessoas com deficiência possuem capacidades de desenvolver outras habilidades não agregadas à sua capacidade biológica (não ouvir, não enxergar, não andar, não exercer de forma plena todas as faculdades mentais ou intelectuais, entre outros) e serem socialmente capazes de realizar a maioria das capacidades exigidas a quem não tem deficiência (Mello, 2016).

Essa relação evidencia-se por meio dos discursos apresentados, nos quais alguns profissionais se mostram dispostos a trabalhar com esses alunos, no entanto, nas entrelinhas e, muitas vezes até de maneira direta, ressaltam que fazem o que é possível, pois esses alunos não são capazes de aprender.

A coordenadora pedagógica I da Escola IX afirma que o aluno com deficiência que frequenta uma turma de terceiro ano, precisa pelo menos contar até 10 ou até 20, demonstrando que dele são esperados conteúdos da educação 
infantil. Espera-se que ele aprenda seu endereço e seu telefone para uma possível situação de emergência. E ainda assim, ela relata que esse trabalho é complicado.

Já a professora regente I, também da Escola IX afirma a impossibilidade dos alunos com Síndrome de Down em realizar a mesma atividade que o restante da turma. Sobre esses mesmos alunos, a profissional de apoio relata os conteúdos trabalhados no segundo ano do ensino fundamental: cobrir pontilhados e escrever sem cobrir os pontilhados. Sendo esses objetivos destinados ao aluno de 8 anos e para o que possui 18 anos, respectivamente. Ela considera que o alcance desses objetivos será uma grande vitória: "se ele conseguir segurar bem no lápis e encobrir os pontilhados, pra mim isso já vai ser um... uma grande vitória" (Professora de Apoio I, Escola IX).

O acompanhamento da rotina da unidade escolar mostrou que as percepções da deficiência como incapacitantes não estão presentes somente no discurso dos agentes, fazem parte da rotina dos alunos com e sem deficiência. O aluno com deficiência é colocado frequentemente em posição inferior aos demais e em algumas situações, essa incapacidade é verbalizada e apontada a eles.

Durante observação de uma turma de quarto ano na Escola IX, a professora fala em voz alta que existem dois alunos na turma que não conseguem aprender e enquanto isso aponta para cada um deles. Ela conta que não consegue dar a atenção necessária para eles e ressalta que precisaria ter a presença de um profissional de apoio. Enquanto isso, os alunos da turma realizam uma atividade de leitura e respondem perguntas sobre um texto do livro didático (a disciplina é de Geografia). Como os alunos com deficiência não são alfabetizados, eles apenas folheiam o livro.

Situações como essas foram vistas nas três escolas observadas e também em quase todas as entrevistas realizadas (com exceção de uma professora do AEE e uma professora regente, das quais falaremos mais adiante), o que demonstra que o olhar está voltado para as "incapacidades" dos alunos com deficiência corroborando as afirmações apontadas pelos Disability Studies. Partindo do ponto de vista individual, centrado na pessoa, os professores justificam a não aprendizagem dos alunos devido à sua condição "com deficiência". Ao fazê-lo, acabam se desresponsabilizando do processo, afirmando que não há muito a ser 
feito, uma vez que os alunos não conseguem aprender. A saída encontrada pela escola, de acordo com os relatos coletados nas entrevistas, é o que eles denominam de "adaptação do conteúdo". No entanto, o que ocorre é aparentemente uma supressão dos conteúdos ministrados aos alunos com deficiência.

A adaptação curricular, garantida pela LDB 9.394/96 e assegurada pela legislação concernente à educação especial (a exemplo das Diretrizes Curriculares para a Educação Especial na Educação Básica/2001; Resolução CNE/CEB n. $\left.{ }^{0} 02 / 2001\right)$ consiste na oferta de "conteúdos básicos, metodologias de ensino e recursos didáticos diferenciados e processos de avaliação adequados ao desenvolvimento dos alunos que apresentam necessidades educacionais especiais, em consonância com o projeto pedagógico da escola" (BRASIL, 2001 p.47 grifo nosso). O que acontece na prática das escolas observadas é a simplificação de conteúdos, uma vez que atividades da educação infantil são disponibilizadas para alunos que frequentam o segundo ano do ensino fundamental e a expectativa é que ao conseguir realizá-las, eles avancem para o terceiro ano.

Durante as observações e entrevistas nenhum dos agentes referiu-se à situação de aprendizagem dos alunos com deficiência considerando-a como fracasso escolar. Aparentemente, os agentes creditam a situação de não aprendizagem dos alunos como algo próprio da deficiência. O professor regente II da escola II refere-se ao conteúdo ministrado para a aluna como "adaptado porque ela não consegue acompanhar" e atribui a adaptação à profissional de apoio. No entanto, ele afirma que a aluna "assiste às aulas entre aspas", pois ela toma medicação que a faz sentir sono e, por esse motivo dorme durante as aulas. Diante disso, o professor afirma que não há nada que ele possa fazer.

As expectativas dos professores podem influenciar o desempenho dos alunos, conforme afirma Soares et al. (2010). Os autores ressaltam que a sintonia entre o desempenho esperado e o desempenho observado é um "reflexo de um diagnóstico baseado em algum conhecimento das capacidades cognitivas dos alunos” (p.168) e também pode estar relacionado às características socioeconômicas dos alunos. Dessa forma, os autores sugerem que o diagnóstico do professor e, consequentemente, suas expectativas estão baseadas em 
estereótipos. No presente estudo, acrescentamos o fato dos alunos possuírem deficiência, o que seria mais um estereótipo que pode influenciar as expectativas dos professores sobre o desempenho dos alunos.

Durante as observações e entrevistas foram verificados apenas dois casos em que uma professora do AEE e uma professora regente relataram situações que não partiram do pressuposto que o aluno não aprendia devido à deficiência.

A professora do AEE I da Escola IX enfatiza que um aluno que possui diagnóstico de deficiência múltipla, atendido por ela, possui pouca idade e sabe muito bem usar o computador. Ela confessa, em determinado momento da entrevista, que nem mesmo ela acreditava que ele saberia usar o computador. Mas depois disso, relata que o aluno ligou o computador sozinho, utilizou todos os comandos necessários e ainda pediu para acessar a internet. Ela relata surpresa com a desenvoltura do aluno, demonstrando não esperar tal atitude. No entanto, percebemos também que situações como essas contribuem para uma desconstrução da imagem de incapacidade associada à deficiência. A professora, que anteriormente dizia que o aluno não seria capaz de utilizar o recurso, questiona a afirmação recorrente de que o aluno com deficiência não aprende ao afirmar: "Vai falar que não aprende? Aprende, gente! Aprende!" (Professora do AEE I, Escola IX). Em outro momento, ela cita outras situações com alunos que frequentam a sala e reforça a importância do uso de recursos alternativos para a aprendizagem. A utilização de revistas, jogos, mídias, tecnologias contribui para que a docente enxergue as capacidades dos alunos.

A Professora Regente I da Escola II, ao descrever sua atuação em uma sala de segundo ano, relaciona as incapacidades dos alunos ao contexto social vivenciado por eles, independente de deficiência. A professora realiza ainda, uma crítica a respeito da maneira como a escola se referiu à aluna com deficiência matriculada na turma. Ela conta que quando iniciou suas atividades na Escola II, recebeu a informação de que em sua turma haveria uma aluna com deficiência. Ela afirma que a descrição da aluna foi "assustadora” (sic).

Segundo a docente, a aluna foi apresentada como alguém que possuía intenso descontrole, necessitando inclusive ser contida com força. A informação gerou na professora uma sensação de nervosismo e medo, ao imaginar as 
possíveis situações que poderia vivenciar com a aluna (ainda desconhecida) durante o semestre. No entanto, ela conta que decidiu esperar para conhecer a aluna e se surpreendeu ao ver que não era nada daquilo que havia sido prenunciado.

Em seguida, a professora conta as perspectivas de aprendizagem para a aluna afirmando que acredita que ela possa fazer muito mais e ressalta: "eu acho que às vezes a sala deixa aquém dela" (Professora Regente I, Escola II). A percepção acerca da deficiência como um fator que não interfere nas capacidades da estudante aparece com frequência no relato da professora. Ela enfatiza toda a gama de possibilidades que a aluna pode alcançar.

A sala da professora foi acompanhada durante os dias de observação da unidade escolar. Foi possível perceber que a aluna está trabalhando o mesmo conteúdo que os colegas de turma e finaliza as tarefas antes dos demais alunos. Em um dos dias da observação nesta sala, foi possível perceber que a professora de apoio, ao terminar a atividade com a aluna, aproximou-se de outros estudantes para auxiliá-los na tarefa. E a aluna com deficiência permaneceu em seu lugar aguardando todos terminarem.

A respeito da maneira como a aluna com deficiência foi "apresentada" a ela, a docente reitera o cuidado que a escola precisa ter ao referir-se a um aluno com deficiência, segundo ela, isso pode criar rótulos: "Na mesa dos professores tem RÓTULO e esse aluno vai criando RÓTULO [...] esse rótulo não desprega mais dele." (Professora Regente I, Escola II). Os rótulos descritos pela professora foram percebidos em diversos discursos coletados durante as entrevistas do campo. Estão presentes nas unidades escolares e em todos os espaços ocupados por pessoas que aprenderam que a deficiência é algo inferior, algo digno de pena. Sobre essa naturalização, Rossato e Leonardo (2011) asseveram que o insucesso escolar dessas pessoas é algo certo e natural e seu sucesso é considerado como algo inusitado. Nesse sentido, os autores enfatizam que as práticas revelam as concepções sobre a sociedade, educação e deficiência e ao mesmo tempo, o quanto tais concepções vão sendo cristalizadas na sociedade.

Oliveira (2017) afirma que a percepção dos agentes escolares em relação ao aprendizado dos alunos pode apresentar aspectos precipitados e, 
eventualmente, discriminatórios, sobretudo se o professor considera que ele tenha supostamente alguma falha biológica ou estrutural. Situações como essas também são descritas por Almeida (2015) que define que, no âmbito escolar, a negação ao acesso de novas habilidades cognitivas básicas necessárias é considerada uma “degradação da oferta de um direito" (p.101).

A forma como a deficiência é considerada parece colocar os alunos com deficiência em uma posição inferior, de incapacidade de aprender. A comparação é realizada tomando como base o padrão de normalidade, enfatizando características capacitistas. A distinção dos discursos que reforçam a visão capacitista da deficiência contrasta dos relatos apresentados pelas professoras que consideram que os alunos são capazes de aprender e evoluir como os demais. A presença de uma percepção que considera que o aluno com deficiência não seja capaz de aprender deixa pouco espaço para a discricionariedade desses agentes, pois a ausência de ações que incentivem o aprendizado desses alunos não é baseada na opção do professor de ensiná-lo ou não, mas sim no fato de que ele desacredita que a aprendizagem seja possível.

Ainda relacionado à percepção dos agentes implementadores destacamos as concepções sobre o conceito de educação especial e educação inclusiva, conforme apresentado no próximo item.

\section{4. \\ Percepções a respeito do conceito de deficiência e educação inclusiva: a escola que acolhe.}

Iniciaremos nossa discussão abordando dois conceitos importantes no que se refere à educação de pessoas com deficiência: o conceito de educação especial e o conceito de educação inclusiva. Como já vimos anteriormente, a educação especial se configurou a partir de uma visão inicialmente segregadora (até a metade do século XX), em que pessoas com deficiência, em sua maioria, recebiam educação em locais destinados exclusivamente para elas (instituições especializadas, classes especiais, por exemplo).

Com a promulgação de documentos de organismos internacionais, sobretudo após a Segunda Guerra Mundial, legislações que ressaltam a importância da construção de um sistema de educação inclusivo, a educação 
especial é inserida nesse contexto. A escola deve atender a todos, incluindo o público da educação especial. Assim, a educação especial volta-se à oferta de ensino de um público-alvo específico, sendo eles pessoas com deficiência, transtornos globais do desenvolvimento e altas habilidades/superdotação. Já a educação inclusiva refere-se à oferta de ensino de todas as crianças e jovens tendo como pressuposto o reconhecimento das diferenças individuais de qualquer origem (Glat, 2007 grifos nossos). Isso pode ser verificado através do PNE 20142024 que ressalta que, ao falarmos de uma escola que seja para todos, estamos falando de todos independente de religião, credo, raça, gênero e não só de pessoas com deficiência.

Camargo (2017) afirma que o conceito de inclusão é um paradigma que se aplica aos mais variados espaços físicos e simbólicos. Em contextos sociais considerados inclusivos, todas as pessoas participam efetivamente, uma vez que identidade, diferença e diversidade representam vantagens sociais que favorecem relações de solidariedade e colaboração.

$\mathrm{Na}$ presente pesquisa, os resultados nos mostraram que a maioria dos agentes relacionou educação inclusiva apenas à inserção de pessoas com deficiência no ambiente escolar. Ao serem perguntados se consideram a instituição que atuam uma escola inclusiva, eles respondem de maneira afirmativa que a escola é inclusiva porque "acolhe" os alunos com deficiência: "Inclusiva porque...acolhe os alunos que...que a gente não tem melindre para...para matricular aluno que tenha algum tipo de deficiência" (Diretora Adjunta, Escola II).

$\mathrm{Na}$ concepção desses agentes, bem como da maioria dos entrevistados, uma escola inclusiva é um ambiente que recebe ("acolhe") estudantes com deficiência em suas salas de aula. A história da educação especial contribui para essa percepção, uma vez que, as pessoas com deficiência possuíam (e ainda possuem) espaços voltados exclusivos para seu atendimento, seja ele na área da educação, saúde e assistência.

Para ilustrar essa situação Jannuzzi (2017), que descreve as ideias incorporadas no início do século XX, ao citar Basílio de Magalhães (1913), enfatiza o isolamento histórico da pessoa com deficiência que era considerada 
como alguém que deveria ser educada em classe separada, não apenas porque não aprendia, como os normais, mas também porque impede que as crianças normais aproveitem a instrução que lhes é proporcionada.

A partir da universalização da educação obrigatória na década de 1990 no Brasil e da implementação de políticas públicas educacionais, que orientam que a educação da pessoa com deficiência deva acontecer preferencialmente no ensino regular, esses alunos chegam à escola regular, assim como outros grupos que anteriormente encontravam dificuldades de acesso à escola, como os mais pobres, os negros ${ }^{87}$ ou os estrangeiros ${ }^{88}$, por exemplo. No entanto, mesmo que outros grupos sociais também estejam ocupando os mesmos espaços, a marca da deficiência, do "anormal", do "diferente" causa considerável impacto.

Outro fator de destaque em relação ao conceito de inclusão expresso pelos entrevistados, diz respeito à forma como eles concebem a inclusão: a escola é inclusiva porque possui alunos com deficiência matriculados e também é inclusiva porque acolhe, cuida e atende esses alunos: "Ela é inclusiva porque ela $E$ acolhedora" (Diretora Administrativa, Escola II); "Assim, eu digo assim mais é a ACOLHIDA, que a gente recebe esses alunos, a questão dos professores, a questão dos administrativos. Já faz parte, a gente recebe há muito tempo essas crianças especiais, né?" (Coordenadora I, Escola IX).

Nos trechos destacados, as entrevistadas enfatizam os aspectos inclusivos das unidades escolares levando em conta o acolhimento prestado aos alunos com deficiência. Dos 22 entrevistados que responderam ao questionamento sobre a escola ser inclusiva, 20 consideram que ela é inclusiva porque acolhe os alunos com deficiência.

A fala da Professora de apoio da Escola II merece destaque, pois ela explicita a relação de dependência da pessoa com deficiência, que necessita de cuidado constante, em todas as atividades, inclusive durante o lanche e o recreio.

\footnotetext{
${ }^{87}$ De acordo com a Pesquisa Nacional por Amostra de Domicílios Contínua - Educação, realizada no ano de $2017,47,4 \%$ das pessoas pretas ou pardas não completaram nem a primeira etapa do ensino básico (IBGE, 2018).

${ }^{88}$ Sendo Corumbá uma cidade fronteiriça, existe um grande número de crianças bolivianas matriculadas nas escolas da rede municipal. No município, famílias bolivianas atravessam a fronteira para que seus filhos nasçam em território brasileiro, portanto, nos dados oficiais eles são considerados brasileiros, porém, possuem como língua materna o espanhol e residem no lado boliviano (COSTA, 2015).
} 
A docente afirma que considera a escola inclusiva porque: "Todos os professores participam, as crianças já tem o entendimento tal com ela, cuidam dela, dão lanche na hora do recreio. Tem um cuidado. Os outros professores também, a coordenação, direção. Todo mundo tem um cuidado especial" (Professora de Apoio, Escola II). Esse cuidado, visto como especial pela professora tem relação com a maneira como a pessoa com deficiência é hegemonicamente vista pela sociedade: uma visão que inferioriza e coloca o sujeito como incapaz de realizar atividades mais simples. Chama a atenção que a professora refere-se a uma aluna que possui diagnóstico de Síndrome de Asperger e não tem nenhum comprometimento motor ou necessidade de adaptação física.

O escasso conhecimento sobre as pessoas com deficiência aparece também no depoimento da professora regente II da Escola IX que aparenta ter dificuldades para escolher a palavra mais adequada para explicar porque a escola é inclusiva: "Acredito que todas as salas, na escola ele tem essa...essa...essa...acolhida, né?". A professora aparenta escolher o melhor termo para definir a permanência desses alunos e demonstrar através de sua fala, como ela enxerga a inserção desses alunos na escola. Ela também ressalta a necessidade de estudar a área, realizar uma especialização: "no meu caso falta um pouco mais, tipo é...estudo, né? Vamos buscar uma especialização para poder estar mais por dentro, ajudar aquele aluno" (Professora Regente II, Escola IX). Ao referir-se à importância de se preparar para o trabalho com os alunos com deficiência, percebemos que a professora utiliza o verbo ajudar, configurando que esses alunos necessitam de um auxílio, um apoio, sem estabelecer nenhuma relação com a necessidade deles terem acesso à aprendizagem, ao direito de aprender.

O professor regente II da Escola II também aparenta não possuir conhecimento acerca da forma de se referir às pessoas com deficiência. Ele defina a aluna com deficiência que frequenta sua turma como: "uma pessoa que já tem o corpo de um adulto, mas é uma criança ainda." (Professor Regente II, Escola II).

Os discursos coletados na pesquisa indicam a presença do capacitismo. Valle e Connor (2014) ressaltam que situações como essas não são propositais, portanto mesmo que apontar essas situações pareça um julgamento é importante ressaltarmos que os pensamentos capacitistas permeiam a nossa cultura e as 
escolas encarnam a cultura em que vivemos. Cada conflito com uma barreira reproduz a categoria da deficiência e atua sobre o corpo considerado ilegítimo, não funcional. Portanto, podemos ver que a fala dos agentes mantém o indivíduo com deficiência em uma posição segregada perante os demais, que, na visão deles, tem capacidades de aprender que eles não teriam.

O histórico do caráter fundamentalmente filantrópico e assistencialista dos serviços voltados às pessoas com deficiência contribui para a ideia de que essas pessoas devam ser amparadas, cuidadas, cercadas de afeto: "todo o meu planejamento eu tento voltar um pouquinho pra eles, por mais que eles não acompanhem" (Professora Regente I, Escola IX). Nesse horizonte, a questão da aprendizagem estaria em um patamar secundário. Realizando um paralelo com o trabalho de Oliveira (2017) que pesquisou a discricionariedade de agentes implementadores da política de correção de fluxo ${ }^{89} \mathrm{em}$ uma escola do município do Rio de Janeiro, encontramos relação com o fato de que os professores percebem os alunos de maneira binária e relativamente estereotipada. Esses mesmos agentes podem basear suas ações em valores culturalmente arraigados, colocando em cheque o ideal de uma educação pública de qualidade, voltada para toda a população (Oliveira, 2017).

Entretanto, essas situações não podem deixar de considerar as condições de trabalho vivenciadas por esses atores. Não consta como objetivo do presente trabalho, a discussão aprofundada acerca das condições de trabalho dos agentes implementadores, porém, para auxiliar as análises realizadas, falaremos brevemente sobre a oferta de formação continuada desses atores no próximo item.

\subsection{1. \\ A formação continuada dos agentes implementadores e sua atuação no âmbito da escola}

A formação continuada dos profissionais que atuam com alunos com deficiência na rede municipal de Corumbá apresentou características autônomas, uma vez que, os professores que declararam ter conhecimento na área de educação

\footnotetext{
${ }^{89}$ Políticas voltadas a alunos que apresentam uma distorção idade-série de dois anos ou mais e, geralmente implementadas através de programas e projetos de aceleração da aprendizagem (Oliveira, 2017 apud Alvarse e Mainardes, 2010).
} 
especial relataram ter aprendido a trabalhar na prática ou realizaram cursos por iniciativa própria. Os professores, independente da atuação (professores regentes, professores do AEE ou profissionais de apoio), relatam ter aprendido sobre educação inclusiva ou educação especial de duas maneiras: realizaram por conta própria uma especialização na área ou aprenderam na prática. Dos cinco professores regentes entrevistados, apenas uma possuía formação em educação especial devido a especializações realizadas por conta própria (professora regente I da Escola II).

Mesmo que exista a previsão de formação nos documentos oficiais que orientam a educação de pessoas com deficiência, ainda não alcançamos essa realidade na prática. Sousa (2017) afirma que as mudanças em relação a isso estão acontecendo de maneira lenta, principalmente no que se refere à formação em seus diversos níveis, retratando as dificuldades que os professores enfrentam em sua caminhada na educação especial e inclusiva. A autora ressalta que os saberes acabam sendo construídos e adquiridos na própria prática pedagógica, vindo de diversos contextos, seja na aprendizagem com os pares, núcleo de apoio pedagógico, alunos, entre outros.

Nesta pesquisa percebemos que os profissionais além de terem apenas a opção de buscar as formações continuadas no campo da educação especial por conta própria, encaram isso como uma obrigação. A professora regente II da Escola IX afirma que necessita ter uma especialização, no entanto, não delega isso como uma responsabilidade do município em ofertar as formações, mas coloca como uma necessidade que ela deve suprir.

Vitor e Oliveira (2017) ressaltam que o professor tende a enxergar sua necessidade de formação como uma iniciativa pessoal, de sua responsabilidade. Entretanto, segundo os autores, a formação de professores deveria fazer parte de um projeto educativo social, político com maior envolvimento do Estado a quem caberia financiar projetos consistentes de formação e criar condições adequadas para que os professores participem desses projetos.

Durante as entrevistas, ao perguntarmos sobre as formações continuadas ofertadas pela secretaria municipal de educação ou mesmo pela escola, os entrevistados informaram que costumam se reunir aos sábados ou em um dia 
(geralmente um por semestre) para discutir algum tema. Os temas são escolhidos pela secretaria e, de acordo com os relatos, via de regra, são referentes ao IDEB e ultimamente sobre a BNCC (Base Nacional Comum Curricular). Não tivemos como objetivo nos aprofundar na temática da formação de professores, mas não foi possível deixar de observar a importância disso na atividade docente.

Já os professores do AEE e profissionais de apoio costumam se reunir com mais frequência, mesmo que não seja com fins de formação, pois os encontros possuem características de reuniões para discussão de práticas ou troca de experiências. No caso dos professores das salas de aula regular, estes não possuem essa interação, tampouco a respeito da temática da educação especial. Assim, aparentemente, os professores do AEE e profissionais de apoio, mesmo que com poucos recursos, apresentam melhores condições de trabalhar com os alunos com deficiência, por sentirem-se mais seguros para realizar seu trabalho. Eles mantêm comunicação constante com as assessoras técnicas do CMADIJ, buscando ajuda para resolução dos problemas que acometem a rotina diária. Os professores da sala de aula regular não contam com essa interação direta. Mesmo que as assessoras técnicas do CMADIJ frequentem a escola de acordo com o cronograma estabelecido, essa relação só acontece nessas datas. Os professores não participam de nenhuma outra atividade voltada à temática da educação especial.

Esse fato pode influenciar diretamente na discricionariedade desses agentes, pois o fato de alguns possuírem conhecimento (uma vez que, para atuar no AEE e ser profissional de apoio é obrigatório que tenha formação e/ou experiência na educação especial) e uma equipe destinada a atender suas demandas, viabiliza que o trabalho seja realizado de maneira mais efetiva. $\mathrm{O}$ professor da sala de aula regular também tem acesso à assessoria técnica do CMADIJ, mas diante de salas de aulas cheias e heterogêneas, a tarefa acaba sendo mais árdua.

Considerando a importância de entendimento do contexto de atuação desses agentes implementadores, apresentamos no próximo item a atuação dos diretores e coordenadores das unidades escolares, agentes híbridos, que reúnem características de burocratas de médio escalão e burocratas de nível de rua. 
Abordamos suas condições de trabalho, bem como as interações realizadas entre a secretaria, os professores e os alunos.

\section{5. \\ A implementação da política no âmbito da gestão escolar:atuação dos diretores e coordenadores}

Conforme já apresentado no início deste capítulo, os diretores e coordenadores entrevistados possuem atuação similar nas três escolas participantes da segunda fase da pesquisa. Os diretores administrativos possuem funções relacionadas à parte financeira da escola, enquanto os diretores adjuntos respondem pela parte pedagógica, juntamente com os coordenadores. As coordenações desempenham um papel mais ligado aos docentes, ofertando materiais didáticos, orientando sobre metodologias, recebendo encaminhamentos de alunos considerados indisciplinados e atendendo as famílias para a resolução das situações trazidas no âmbito da escola.

Algo comum nas três escolas é que a equipe de gestão é a responsável pela escolha das séries onde cada professor irá trabalhar, bem como a alocação dos alunos por turma. Dessa forma, são eles que decidem quais professores irão atuar nas turmas que possuem alunos com deficiência e a quantidade de alunos que frequentarão cada turma. Nas três escolas observadas buscamos verificar se a Deliberação 402/2015 do Conselho Municipal de Educação, que prevê a redução de alunos por turma em casos de matrícula de alunos com deficiência estava sendo cumprida ${ }^{90}$.

Nas Escolas II e IV o direito referente à redução de alunos por sala não é cumprida. Na Escola II a justificativa é a pequena quantidade do número de salas de aula, atrelada a alta demanda por vagas na escola. A coordenadora ressalta que não há espaço suficiente para matricular todos os alunos que procuram a escola e que todas as salas estão lotadas. Por esse motivo ela afirma que não existem condições para reduzir a quantidade de alunos em nenhuma turma. Já na Escola

\footnotetext{
${ }^{90}$ Importante ressaltar que a Supervisora II do Núcleo de Inclusão Escolar e Diversidade informou durante a entrevista que, nos casos em que o aluno com deficiência contar com o profissional de apoio, a redução de alunos não se faz necessária. Segundo a supervisora, se o aluno conta com profissional voltado exclusivamente para atendê-lo, não é necessário que a sala seja reduzida.
} 
IV, a legislação municipal não é cumprida, pois nenhum aluno considerado com deficiência possui laudo médico. A redução do número de alunos por sala só ocorre através da comprovação da deficiência por meio de laudo.

A Escola IX consegue cumprir a legislação referente à redução de alunos por turma. Todas as salas de aulas observadas contavam com cerca de 20 alunos e, algumas delas, além do número reduzido, o aluno com deficiência também contava com profissional de apoio. Na Escola IX encontra-se o local de funcionamento do CMADIJ, bem como várias salas de atendimento educacional especializado, o que propicia que os alunos que apresentam suspeita de deficiência sejam encaminhados ao centro com maior celeridade. Acreditamos que este seja um fator que influencia a escola a cumprir a Deliberação 402.

A celeridade do atendimento aos alunos da Escola IX por parte do CMADIJ fica evidente nos discursos das agentes escolares entrevistadas. "A gente precisou... algum aluno com necessidade especial, a gente está com alguma dificuldade a gente aciona o CMADIJ e eles nos ajudam. Vêm! Intervém, né? [...]Toda vez que eles são solicitados vêm um técnico nos ajudar" (Coordenadora II); “a gente sempre está procurando ali, o CMADIJ" (Professora Regente I); "Na verdade assim, nós temos um departamento. Não sei se eu falo um departamento...uma área...da educação especial aqui no [nome da escola] que é o CMADJI' (Diretora Administrativa).

A fala da diretora faz parecer que ela não sabe exatamente qual a nomenclatura do CMADIJ, uma vez que ela apresenta dúvidas em relação à terminologia do centro. Sua fala relaciona-se com o discurso das assessoras técnicas do CMADIJ, descritos no capítulo III, que afirmaram que percebem certa invisibilidade em seu trabalho.

Em relação ao atendimento dos alunos no AEE, a diretora adjunta da Escola II enfatiza a importância de ter uma sala de recursos multifuncionais na escola ao contar sua experiência como diretora administrativa na zona rural. Ela afirma que a presença do profissional propicia o suporte às atividades realizadas com os alunos com deficiência e ressalta que na ausência de uma sala de AEE, o aluno acaba "esquecido", pois, segundo ela, os professores da escola não têm suporte para realizar o trabalho com eles, a equipe de gestão, não tem condições 
de dar pleno apoio ao processo de ensino e aprendizagem desses estudantes e, então, problemas de aprendizagem podem, inclusive, ser considerados deficiência.

Durante as entrevistas, foi possível perceber que a atuação da equipe da gestão prioriza outras ações, que não o atendimento ao aluno com deficiência. A respeito dos alunos, eles relatam atender casos de indisciplina, famílias que procuram a escola para resolver alguma situação específica. Ao serem perguntados sobre os alunos com deficiência, eles citam o CMADIJ, explicitando que existem profissionais destinados exclusivamente para isso, sem que haja necessidade do envolvimento direto deles para a resolução dos problemas.

Importante ressaltar que os documentos referentes às políticas da educação especial enfatizam a necessidade de participação de todos na construção de uma escola considerada inclusiva, sendo responsabilidade da comunidade escolar, incluindo aí o projeto político-pedagógico da escola. A política de educação especial atenta para a necessidade de criar um ambiente que considere as especificidades da comunidade, suas reais demandas e os ajustes que devem ser feitos levando sempre em conta os aspectos sociopolíticos, administrativos e didático-pedagógicos com o objetivo de diminuir as distâncias entre o que se quer e o que se tem (BRASIL, 2004). A política enfatiza tais questões, no entanto, a realidade encontrada nas escolas acaba não contribuindo para que os agentes implementadores encontrem as condições adequadas para atuar, baseando suas atividades nesses preceitos.

Os discursos coletados nas entrevistas, apontam para a total responsabilização do CMADIJ em praticamente todos os procedimentos referentes à implementação da política de educação especial do município, desde os encaminhamentos realizados pela escola, até o envio de profissionais de apoio e professores de AEE para acompanhar os alunos. Na entrevista com a diretora da Escola IX questionou-se a respeito de como a demanda do profissional de apoio é realizada. Ela afirma que: "é o CMADIJ que manda [...] Eles têm uma listagem de todos os alunos da rede que tem... a necessidade...e aí eles fazem a triagem. Esse processo todo é feito pelo CMADIJ." (Diretora Administrativa, Escola IX). Já a diretora adjunta da Escola II relata a atuação do CMADIJ no processo de identificação e encaminhamento do aluno com deficiência: “vem, já identifica, já 
fala, já orienta, se tem ou não (refere-se à deficiência) se vai encaminhar pro médico, se vai encaminhar pra fono (sic)...” (Diretora Adjunta, Escola II).

Já o coordenador da Escola IV chega a interromper a pergunta referente ao encaminhamento dos alunos com suspeita de deficiência, afirmando: "eles que fazem!" (Coordenador, Escola IV). A escola, que não possui nenhum profissional específico para o atendimento dos alunos com deficiência é a que mais apresenta falta de informações a respeito do centro e de todos os atendimentos destinados a esse público. No entanto, a fala dos entrevistados apresenta a angústia que eles sentem pela grande demanda existente na escola.

Quanto à interação da Escola IV com o CMADIJ, o coordenador afirma que pede apoio, que a assessora técnica frequenta a escola, mas que ele sente a necessidade de ter um profissional específico para o atendimento desses alunos dentro da escola. O coordenador parece sentir receio ao fazer tais afirmações, mas sente a necessidade de afirmar as condições existentes na escola em relação ao que ele considera ausência de apoio. Nesta escola, ele conta o caso de um aluno que está repetindo pela quarta vez o segundo ano. Ele mostra extrema preocupação, pois relatou o fato desde a primeira visita na escola para as observações. Pediu ajuda, chamou as professoras para conversar, solicitou ajuda na condução dos problemas. Na ocasião foi esclarecido que após a realização da pesquisa, os resultados seriam apresentados à escola e talvez pudessem auxiliar.

A situação apresentada pelo coordenador da Escola IV mostra que, além da situação da falta de apoio, a equipe da escola também não consegue realizar um acompanhamento mais direto dos alunos com deficiência, porque eles não são capacitados para atuar com esses alunos. As formações ofertadas, na realidade, são reuniões de trabalho, onde são discutidas as demandas da rede e feitas orientações quanto à atuação de cada gestor.

Outro ponto diz respeito à necessidade das escolas em realizarem festivais de prêmios, rifas, comercializarem alimentos dentro da escola com o objetivo de arrecadarem dinheiro. A diretora administrativa da Escola II afirmou que o repasse de recursos não é suficiente, que a escola está sem reforma há anos e que necessita de constantes reparos. Ela enfatizou que anteriormente, era possível negociar com empresas para realizar serviços emergenciais e, com o repasse da 
verba, o pagamento era realizado posteriormente. Porém, essa prática não é mais permitida.

A prática de arrecadação própria de recursos é algo corriqueiro no cenário da educação brasileira, mesmo que proibida em alguns estados, como exemplo de Minas Gerais e Paraná. Porém, Peroni e Adrião (2007) afirmam que a arrecadação de recursos por parte das escolas é uma das questões mais controversas dentro do Programa Dinheiro Direto na Escola, uma vez que a prática estimula a busca de recursos na comunidade, desobrigando o Estado de financiar a escola pública.

Pensar na atuação dos diretores e coordenadores implica considerar o contexto em que eles estão inseridos, as demandas advindas da comunidade, sobretudo, a precariedade existente na unidade escolar, que faz com que esses atores priorizem aspectos básicos para garantir o funcionamento da escola (uma lâmpada, a porta de um banheiro, um bebedouro). A ausência de apoio para esses profissionais obriga (utilizando a palavra da própria diretora administrativa da Escola II) a realização de outros meios, utilização de estratégias que possibilitam que o mínimo seja ofertado. Em contrapartida, as cobranças em relação à qualidade são mantidas pela secretaria.

As dificuldades existentes quanto às condições de funcionamento nas escolas observadas não pareceram ser algo que gerasse revoltas ou cobranças por parte dos gestores. A impressão que se tem é que eles aceitam as condições impostas e procuram sanar as necessidades, mesmo que para isso seja necessário investir recursos próprios. Nesse sentido, Barbosa (2018) afirma que a precariedade exige do campo da educação o máximo de atenção devido à sua dimensão, alcance e causa. $\mathrm{O}$ autor refere-se também à necessidade de pesquisas que tratem dessa temática e enfatiza que o posicionamento da educação perante os problemas existenciais, considerados urgentes e desafiantes é algo que, por vezes, ocorre com certa demora, seja pelo imobilismo que afeta os sistemas educativos, seja por alguma inépcia na compreensão desses problemas.

Sobre a desresponsabilização, o coordenador da Escola IV refere-se mais uma vez ao aluno com 12 anos que está retido no $2^{\circ}$ ano e possui suspeita de diagnóstico de deficiência e enfatiza que não sabe o que fazer para resolver a situação. Afirma que já tentou vários contatos com a família, inclusive solicitando 
que eles realizem a matrícula do aluno na instituição especializada de caráter filantrópico, pois acredita que lá ele terá mais apoio. Porém, não obteve retorno dos responsáveis pelo aluno, que continua frequentando a escola. A fala do coordenador nos mostra aspectos relacionados ao capacitismo e à sua discricionariedade em definir o "melhor" local para o aluno com deficiência receber atendimento educacional "adequado". O coordenador considera correto que esse aluno frequente um espaço com alunos "como ele": "já pedimos para os pais...fazer matrícula dele na...APAE. Pra dar mais apoio, mas acontece que aí a gente não tem esse apoio da família. A família...é...não liga” (Coordenador, Escola IV). Mesmo que o agente escolar não tenha a intenção de considerar o aluno explicitamente como inferior, seu discurso está carregado desse sentido, pois ele afirma que a situação é um problema para a escola e que a causa de não resolver esse "problema" é o fato da família não o encaminhar para a escola especializada.

Dessa forma, a implementação das políticas da educação especial, as situações descritas apontam para a desresponsabilização de diversos agentes: a secretaria municipal de educação, que parece cobrar a escola em relação aos resultados obtidos, sobretudo nas avaliações externas, porém aparenta se isentar quanto às condições de funcionamento das escolas; a equipe de gestão da escola que atribui toda a responsabilidade do acompanhamento do aluno com deficiência ao CMADIJ, desde sua avaliação, acompanhamento, contato com as famílias, orientações aos professores sobre as adaptações curriculares, dentre outras ações que se encontram centralizadas na equipe do CMADIJ, professoras do AEE e profissionais de apoio. Ou seja, responsabilizam-se pelos alunos com deficiência somente aqueles que atuam diretamente com eles e que, possivelmente, apresentam formação para realizar esse trabalho. $\mathrm{Na}$ ausência de uma atuação mais direta desses profissionais, a responsabilização recai sobre a figura da família.

A partir dessas análises, lançamos o seguinte questionamento: se existe uma equipe especializada (mesmo que incompleta) para se preocupar com as questões ligadas às pessoas com deficiência, por que isso seria uma prioridade para o gestor escolar? A participação dos gestores na condução dos atendimentos 
voltados aos alunos com deficiência existe, porém, através de um acompanhamento da situação (participação em reuniões, por exemplo).

A situação é corroborada com os discursos apresentados pelos diretores e coordenadores participantes da pesquisa, que em sua totalidade conheciam o procedimento para encaminhar os alunos com deficiência. Todos eles enfatizam que, a partir da chegada ou descoberta de um aluno com deficiência na escola, eles procuram imediatamente as assessoras técnicas e solicitam auxílio. Durante a entrevista com o grupo das três assessoras técnicas do CMADIJ, presenciamos uma situação em que uma delas recebeu um laudo, enviado pelos gestores por meio de um aplicativo de mensagens instantâneas. Ou seja, a partir da chegada da demanda, ela é imediatamente encaminhada a quem "deve" resolver a situação.

Entendemos que essa situação ocorra devido à percepção dos gestores em relação à deficiência, pois não há muito o que fazer, uma vez que tais alunos não conseguem aprender. Além disso, a falta de conhecimento dos gestores em relação à temática das deficiências também pode influenciar sua atuação. Dessa forma, a partir do momento que se deparam com uma situação relacionada a um aluno com deficiência, não encontram outra saída para resolvê-la, a não ser solicitar a ajuda do CMADIJ, que atende a demanda e realiza todo o processo. $\mathrm{O}$ fato também indica que a atuação do CMADIJ, de certa maneira, acaba por desresponsabilizar as escolas em relação à implementação da política de educação especial no município.

O próximo item apresenta a atuação dos professores regentes, professores de apoio e professores do AEE (os BNRs na implementação da política no âmbito da rede municipal)

\section{6. \\ Burocratas de nível de rua: interações entre os agentes implementadores da linha de frente}

Os burocratas de nível de rua consistem nos profissionais que atuam diretamente com o público alvo das políticas públicas. Lipsky (2010) afirma que, como burocratas de nível de rua, os professores são os que decidem se um aluno será suspenso ou não, se permanecerá na escola, além de fazerem determinações sutis sobre quem pode aprender. Ademais, o contexto também interfere 
diretamente na atuação do burocrata que atua na educação, pois constantemente eles se deparam em situações complicadas e que impedem que seja seguido apenas o roteiro determinado pela política pública. Essas normas prevalecem até certo ponto, uma vez que toda criança requer uma resposta adequada ao contexto específico de sua aprendizagem (idem).

No presente trabalho serão considerados burocratas de nível de rua os professores regentes, os professores do atendimento educacional especializado e os profissionais de apoio, devido à sua atuação direta com os alunos com deficiência, seja em sala de aula ou na sala de recursos multifuncional.

Os profissionais de apoio e professores do AEE possuem formação em educação especial, Psicopedagogia ou experiência na área, sendo o cumprimento de pelo menos uma dessas exigências o pré-requisito para sua contratação. Diante disso, observações realizadas nas Escolas II e IX apontaram para um trabalho mais individual desses profissionais com os alunos. Em uma das salas observadas na Escola IX, a profissional de apoio realizava atividades com uma aluna com Paralisia Cerebral, enquanto isso, o professor regente aplicava uma atividade em grupo para os outros alunos. Os estudantes sentavam-se aos pares para realizar a tarefa. A aluna com Paralisia Cerebral permanecia sozinha com a profissional de apoio, realizando outra atividade.

Sobre o profissional de apoio, Carneiro (2012) destaca que, apesar da legislação prever um profissional para acompanhar o aluno com deficiência no cotidiano escolar, na prática, esse profissional acaba sendo identificado na comunidade escolar como o professor da pessoa com deficiência. Quanto à implementação da política de educação especial, o aluno com deficiência possui matrícula e presença em sala de aula garantidas, porém, pouco interage com os colegas e professores. Mesmo que a legislação e os documentos dos organismos internacionais apregoem que a educação deve ser ofertada a todos, sem distinção, o ensino do aluno com deficiência acaba por ser conduzido pelos profissionais de apoio ou professores do AEE.

A aluna com diagnóstico de paralisia cerebral, ao menos durante o período de observação, não interagiu com nenhum dos colegas. A impressão que se tinha era que ela não pertencia ao grupo e apenas estava no mesmo local que os demais 
alunos. A situação remeteu a um texto de Pierre Bourdieu e Patrick Champagne chamado Os excluídos do interior, onde os autores descrevem a escolarização dos chamados "marginalizados". Bourdieu e Champagne (1997) ao descreverem o contexto educacional francês após o período de democratização (década de 1950) analisam os processos de exclusão baseadas na ordem social. A escola por meio da hierarquia das ordens de ensino (sobretudo quanto à divisão dos ensinos primário e secundário) mantinham relação direta de homologia com a hierarquia social, contribuindo para convencer aqueles que não se sentiam "feitos" para a escola, de que eles não eram aptos para terem os acessos que a escola proporciona (grifo nosso). A esse respeito Faria (2010) relaciona a situação a um jogo de cartas bem definido que contém barreiras bem demarcadas entre os que possuem o acesso e usufruem do sistema e aqueles que não possuem essa condição.

Mesmo que a relação apresentada não possua como foco central os alunos com deficiência, realizamos esse paralelo para nos ajudar a pensar sobre a situação desses estudantes na escola regular. Eles ocupam os mesmos espaços, porém, não acessam os mesmos conteúdos e não compartilham das mesmas oportunidades. É uma “inclusão" mascarada, precarizada.

Pinheiro e Duarte (2017) afirmam que o processo de inclusão de alunos com deficiência ainda tenta se descolar de representações históricas e carrega consigo essas ideias que se refletem diretamente nas ações e representações que circulam na escola. A oferta de uma educação especializada, mesmo que dentro da escola regular, acaba assumindo o lugar de "estrangeiro", ou do estranhamento dentro do espaço, ou ainda um lugar que marca os sujeitos da falta (grifo das autoras).

A profissional de apoio da Escola IX descreve sua atuação durante a entrevista, no entanto, em nenhum momento relata a interação com a professora regente. Quando perguntada a respeito da interação com a regente, ela afirma que trabalham em conjunto. Porém, ao detalhar as ações, atribui a si a responsabilidade de ensinar os alunos.

O discurso das profissionais parece permeado por percepções e práticas contraditórias. Ora afirmam com veemência que o aluno não pertence a elas, que o aluno é de todos e a relação de ensino e aprendizagem cabe ao professor regente, 
ora, ao descrever sua prática profissional, acabam deixando claro quais os objetivos que pretendem alcançar com aquele aluno, assumindo sua responsabilidade.

O discurso dos professores regentes corrobora com as afirmações anteriores. A professora regente II da Escola IX refere-se à profissional de apoio como "a professora, lá... que era especialista mesmo, né?” (Professora Regente II, Escola IX) em outro momento ela ressalta a importância da presença da profissional, pois não consegue atuar sozinha nesse caso: "Mas ele (o aluno) precisa de alguém ali. Então eu acho que eu, ali na sala, só eu, não ia conseguir" (Professora Regente II, Escola IX). Vemos, portanto, que a professora regente considera fundamental a presença do profissional de apoio, alegando que, sem ela não seria possível conduzir tudo sozinha.

Ainda na Escola IX, a professora regente I refere-se ao trabalho da profissional de apoio, atribuindo a ela a responsabilidade de ensinar. A atuação da regente é apenas um auxílio: "E aí a partir de hoje ela já... já vai ver o que ela pode utilizar de material concreto, né? [...] Espero que eu possa ajudá-la." (Professora Regente I, Escola IX).

Sobre o profissional de apoio, Lopes (2018) destaca que a atuação desse profissional tem acontecido, em um contexto nacional, de forma precária, indefinida, não padronizada e com conflitos e equívocos, mesmo que a necessidade da sua atuação e sua importância sejam amplamente reconhecidas. A autora enfatiza a necessidade de uma atuação conjunta de todos os profissionais da unidade escolar, na realização do trabalho do aluno com deficiência. Ademais, Lopes assegura que é primordial a diferenciação do profissional de apoio e do professor de apoio. O profissional de apoio é responsável pelo suporte ao aluno, em atividades em que ele apresente dependência (cuidados básicos, auxílio nas atividades escolares). Já o professor de apoio é um profissional com formação acadêmica que atua dando suporte ao professor regente no planejamento e no ensino.

"Por se tratar de uma prática nova no ambiente escolar, cada município tem-se organizado de uma determinada forma na tentativa de oferecer o ideal de acordo com os princípios que defendem no contexto da inclusão escolar" 
(LOPES, 2018 p. 148). No município de Corumbá o profissional de apoio acaba tendo suas funções mescladas com as funções de um professor de apoio. A legislação municipal apresenta a nomenclatura professor de apoio (Corumbá, 2017), porém, as descrições referem-se à atuação de um profissional de apoio, pois cabe a ele o auxílio nas atividades de vida diária e também dando o suporte à aprendizagem do aluno. Importante lembrar que a exigência para a contratação do profissional de apoio no município de Corumbá é a mesma exigência de contratação de um professor de apoio (formação e/ou experiência em educação especial), o que acaba por confundir ainda mais o papel do profissional.

A respeito da atuação do professor regente em interação com o profissional de apoio, na Escola II, percebemos a importância do conhecimento em relação à área da educação especial. A profissional de apoio relata que todas as atividades são preparadas pela professora regente e todas as ações são planejadas em conjunto. A profissional de apoio também relata que a professora regente chama a aluna para ir ao quadro resolver as atividades, assim como os demais alunos da turma.

Já na Escola IV, que não possui profissional de apoio, a necessidade é destacada pelos entrevistados. A professora regente afirma que não dá conta de realizar as atividades com toda a turma, pois os alunos, que ela considera que têm deficiência, demandam atenção constante. Ela relata não saber o que fazer e ao ser questionada sobre o que falta na escola para que ela seja considerada inclusiva, afirma que falta profissional de apoio, pois seria excelente para as crianças que tem muita dificuldade em aprender. Durante as observações do campo, ela contou que leva pintura, desenhos, para que eles façam, enquanto os outros alunos realizam uma tarefa do livro didático, por exemplo. Aparentemente a percepção de ter demandas de públicos muito diferentes é bastante forte e imobilizadora, talvez até mais do que o esforço profissional ou o desejo de promover a aprendizagem de todos. Dessa forma, conscientemente ou não, as oportunidades oferecidas para que todos aprendam podem ser fortemente restringidas.

$\mathrm{Na}$ Escola IV, existe o caso relatado anteriormente, de um aluno retido no $2^{\mathrm{o}}$ ano com idade de 12 anos. Sobre esse caso, a professora regente afirma que não há nada a ser feito, pois já relataram ao CMADIJ, porém eles solicitam a presença 
da família para realizar a avaliação. Até o momento de realização da pesquisa, a família não havia comparecido à unidade escolar. Por esse motivo, a professora ressalta que não há nada a ser feito. $\mathrm{O}$ discurso se repete em relação à uma aluna de outra turma de $2^{\circ}$ ano, que apresentou diversas suspeitas de diagnósticos. A aluna necessita ser avaliada, no entanto, diante da ausência da família às convocações da escola, a estudante permanece sem avaliação e sem nenhum encaminhamento. A professora regente da turma também afirma que não há nada a ser feito.

A visão de que todos devem se comprometer com a educação, desconsiderando as condições da escola e das famílias para conduzirem esse processo, deve ser analisada com atenção. Da Silveira Nunes, Saia e Tavares (2015) afirmam que a educação inclusiva não fica imune à lógica de que a escola e as famílias possuem mundos paralelos e que é necessário construir pontes para superar os abismos existentes.

Quanto à interação dos professores do AEE com os demais agentes, é importante destacar que a política que garante o atendimento educacional especializado não prevê o funcionamento da sala de recursos em todas as unidades escolares e garante que, nos casos em que a escola não possua a sala de recursos, o aluno com deficiência receba o atendimento em uma escola próxima. No entanto, faz-se necessária a interação entre o professor regente e o professor do atendimento educacional especializado, conforme preconiza o documento do Programa de Implantação das Salas de Recursos Multifuncionais.

Na Escola IX, a professora do AEE II informa que atua na escola apenas $20 \mathrm{~h}$, trabalhando as outras $20 \mathrm{~h}$ em outra unidade. Ela atende vários alunos de outras unidades escolares, no entanto, relata dificuldades em ir até as outras escolas. A entrevistada afirma que o trajeto até as escolas é de responsabilidade das próprias professoras, não sendo disponibilizado meio de transporte para que elas possam realizar as visitas. A situação demonstra a dificuldade na efetivação das orientações contidas na política de âmbito federal, uma vez que, na esfera municipal não são ofertadas as condições adequadas para que a profissional consiga dialogar com os professores das salas regulares em que os alunos atendidos por ela estão matriculados. 
No caso das escolas que possuem salas de recursos multifuncionais (Escola II e Escola IX) a troca entre os profissionais parece auxiliar o trabalho realizado em sala de aula. As professoras do AEE relatam procurar os profissionais de apoio, professores regentes ou professores das disciplinas (no caso de alunos que frequentam os anos finais do Ensino Fundamental) para realizar estudos de casos, orientações sobre metodologias e uso de materiais adaptados e sugestão de atividades.

Já a Escola IV, que não possui sala de recursos multifuncional, mesmo que existam duas escolas próximas que possuam tal sala, os docentes não relataram ter interação com os professores do AEE dessas escolas. Dos alunos acompanhados durante a pesquisa, apenas um frequenta a sala de recursos multifuncional de uma unidade escolar próxima, de acordo com o coordenador.

A Política Nacional da Educação Especial na Perspectiva da Educação Inclusiva preconiza que o atendimento educacional especializado deve identificar, elaborar e organizar recursos pedagógicos e de acessibilidade com o objetivo de eliminar barreiras para a participação dos alunos, no entanto, tais atividades devem ser diferenciadas daquelas ofertadas na sala de aula comum, não sendo substitutivas à escolarização. O AEE deve suplementar a formação dos alunos para garantir sua autonomia e independência na escola e fora dela (BRASIL, 2008).

A respeito da importância da atuação do professor do AEE, Dos Anjos e Da Cruz Souza (2016) ao realizarem levantamento das teses e dissertações do Programa de Pós-graduação em Educação da Universidade Federal do Espírito Santo no período de 2008 a 2015 apontaram que as pesquisas revelaram a necessidade de organizar o AEE a partir de uma ação mediada e intencional planejada de acordo com as especificidades dos alunos público-alvo da educação especial. Para tanto, a sala de recursos multifuncional não deve se constituir como um espaço distante e desarticulado da sala de aula comum, ela precisa estar em consonância com o Projeto Político Pedagógico da escola, à medida que cumpre o papel de suplementação/complementação do trabalho realizado em sala de aula.

No presente trabalho, verificamos que a vinculação do trabalho do professor do AEE e do professor regente apresenta muitas dificuldades e a 
frequente ausência de interação reflete tende a se refletir diretamente na aprendizagem do aluno com deficiência. Os professores do AEE que conseguem fazer essa mediação destacam que seus alunos apresentam bons resultados, no entanto, aqueles que declaram que não conseguem manter um diálogo com os professores regentes, enfatizam as dificuldades e a impotência diante dessa situação. Já as escolas que não contam com uma sala de recursos, encontram-se ainda mais distantes de um trabalho conjunto com o professor do AEE, pois seus alunos enfrentam mais dificuldades em frequentar esse espaço.

Mesmo que a política pública preveja o atendimento dos alunos com deficiência em outras unidades que contem com a sala de recursos, percebemos que quando a escola não tem esse espaço, essa interação não acontece ou acontece de maneira tímida e pouco eficaz. A responsabilidade acaba sendo transmitida, mais uma vez, ao CMADIJ e à família.

Miranda (2016) afirma que a articulação do trabalho desenvolvido pelo professor do AEE e o professor da sala de aula regular ainda está em construção, uma vez que de um modo geral, não há uma sistematização do trabalho de articulação e este tampouco estaria previsto no Projeto Político Pedagógico da escola. Ademais, a maioria dos docentes do ensino regular não dominam os aspectos pedagógicos e as concepções sobre os alunos com deficiência, via de regra parecem ter pouca disponibilidade e tempo para a realização de trabalho em equipes multidisciplinares.

Assim, ao verificarmos o trabalho dos profissionais de apoio e professores do AEE, atores que interagem de maneira mais próxima com o aluno com deficiência na maioria dos casos, percebemos um esforço para a realização do trabalho, com pouca interação com os demais agentes implementadores, a não ser pela proximidade com a equipe do CMADIJ.

Os agentes implementadores do nível de rua que atuam diretamente com os alunos com deficiência mantêm maior contato com os agentes implementadores do médio escalão que respondem pelo setor responsável pela educação especial no município. Ocorre uma intermediação de ação somente daqueles que são responsáveis diretos pelos alunos com deficiência. Os demais agentes implementadores apresentam pouca atuação, apesar de sua importância, 
principalmente devido à falta de conhecimento e visões capacitistas acerca da deficiência.

Dentre as situações observadas, destacamos a atuação da professora regente I da Escola II. Durante a entrevista, ela relata o caso de um aluno que não possui suspeita de deficiência e que apresentava considerável dificuldade em acompanhar o conteúdo. A professora conta que chamou a responsável pelo aluno para uma conversa e externou sua preocupação em relação a ele. A responsável informou que ele perdeu um ente da família quando tinha dois anos e, desde então, passou a apresentar mudanças no comportamento, segundo ela. A professora questiona se a responsável já contou isso anteriormente para alguém da escola ou procurou ajuda, diante da resposta negativa, a professora orienta a responsável a procurar a direção da escola. Ela destaca que, aparentemente o aluno não possui nenhuma deficiência, mas sua aparente angústia está refletida em seus cadernos, pois ele frequenta o segundo ano e não lê e nem escreve uma só palavra.

Posteriormente, a professora é chamada pela direção da escola que pergunta sobre o caso e afirma que o aluno está matriculado na escola há três anos e nunca haviam sequer sinalizado, anteriormente, que ele apresentava alguma dificuldade em aprender. A professora então ressalta que, casos como esse contribuem para que os alunos deixem de frequentar a escola e afirma: "Vai chegar em uma idade que ele não vai mais querer [...] e aí vai desistindo, né? Vai sendo empurrado, vai sendo empurrado e ai desiste!" (Professora Regente I, Escola II). Ela reitera que, diante de situações assim é muito fácil afirmar que uma criança tem deficiência.

O olhar da professora é voltado a todos os alunos, independente de ter uma suspeita prévia de deficiência. A docente procura saber das situações vivenciadas pelos alunos fora do ambiente escolar, conversa, pergunta para a família, orienta sobre encaminhamentos, leva a situação até a direção da escola para que ações sejam tomadas em relação às dificuldades vivenciadas pelo estudante, agindo na contramão do que geralmente ocorre nas escolas: a crença na incapacidade do aluno com deficiência. A percepção de que ele não irá aprender devido à sua 
deficiência. Kassar (1995) destaca que essa situação acaba contribuindo para um retardamento no desenvolvimento do aluno.

\begin{abstract}
Se o compromisso com a educação existe, é inconcebível justificar o fracasso escolar pela "não-adequação" das estruturas familiares dos alunos, heranças biológicas, ou pelas condições sociais e econômicas. O conhecimento dessas condições deve ser um passo em direção a superá-las e não simplesmente contemplá-las. A partir de um enfoque crítico da constituição da sociedade, é viável a opção do professor por desmistificar sua clientela (KASSAR, 1995 p, 88).
\end{abstract}

O olhar do burocrata de nível de rua nesses casos é primordial para garantir que, alunos que não possuem deficiência não sejam tratados como alunos com deficiência devido a dificuldades de aprendizagem, por exemplo. Nesse sentido, a presente pesquisa que teve por objetivo verificar o processo de implementação da política de educação especial a partir da atuação dos agentes implementadores verificou que, mesmo com pequena margem de discricionariedade devido às condições observadas nas escolas, bem como as percepções acerca da deficiência, os burocratas de nível de rua que possuem um olhar voltado para as necessidades de todos os alunos, sem considerar a deficiência como um aspecto limitador contribuem para que a política seja implementada em seu objetivo mais amplo: ofertar educação para todos os alunos, sem distinções.

Nesse sentido, Lima e D’Ascenzi (2013) afirmam que o processo de implementação é definido a partir da consequência de uma intenção (expressa no plano) e os elementos do contexto de ação. Assim, é possível integrar esses dois elementos e inserir variáveis cognitivas, tais como ideias, valores e visões de mundo dos atores. Ainda nesse aspecto, Arretche (2001) ressalta que a diversidade de contextos de implementação pode produzir resultados inteiramente diversos em realidades diferentes. A autora afirma que as instituições impactam as práticas, porém, as ações, valores e contextos dos indivíduos impactam as instituições.

O olhar voltado para todo o grupo de alunos, apresentado pela professora II, aparenta características relacionadas ao denominado Desenho Universal para a Aprendizagem. O conceito de desenho universal foi desenvolvido originalmente na Arquitetura na década de 1960, a partir da exigência de se criar prédios acessíveis aos cidadãos com restrições de mobilidade. O líder do movimento, Ron 
Mace, descobriu que repensar como os prédios eram tradicionalmente configurados na verdade beneficiaria a todos os usuários (VALLE E CONNOR, 2014 grifos dos autores). Um exemplo comumente utilizado para mostrar a importância do desenho universal consiste na construção de rampas. Uma rampa pode ser utilizada por uma pessoa com deficiência física, mas também pode ser utilizada por uma pessoa idosa, obesa ou uma mãe que empurra um carrinho de bebê (Valle e Connor, 2014; Zerbato e Mendes, 2018).

$\mathrm{Na}$ perspectiva da Educação Inclusiva esse conceito foi trazido para pensar a relação de ensino e aprendizagem, levando em conta a diversidade humana. Nesse sentido, o conceito de Desenho Universal possibilita que tanto as pessoas com deficiência quanto às pessoas sem deficiência tenham acesso ao saber. No contexto da relação de ensino e aprendizagem, o conceito de Universal Design of Instruction $^{91}$ (UDL) considera a variação potencial das habilidades individuais, levando em conta estilos e preferências, idade, sexo, orientação, cultura, habilidades e deficiências. São então selecionados conteúdos apropriados e criadas estratégias para a realização das atividades. Trata-se de uma abordagem curricular que procura reduzir os fatores de natureza pedagógica que poderão dificultar a aprendizagem, assegurando dessa forma o acesso, a participação e o sucesso dos alunos (Nunes e Madureira, 2015). No caso dos alunos com deficiência, o desenho universal possibilita que o professor projete e integre um conteúdo acessível, em benefício dos alunos com e sem deficiência (BURGSTAHLER, 2008).

A necessidade de se pensar uma forma de ensinar que contemple a diversidade humana surgiu devido à herança histórica da segregação social que acolhe poucas variações referentes ao modo de aprender, perpetuando a lógica da normalização e a produção do capacitismo. Tal norma privilegia determinadas formas de aprender, e todos que se distanciam dessa normativa enfrentam dificuldades para acessar o conhecimento (BOCK ET AL., 2018).

\footnotetext{
${ }^{91}$ Desenho Universal para Aprendizagem, em tradução livre.
} 
A proposta de um desenho universal para aprendizagem ${ }^{92}$ é sustentada pela ideia defendida na Convenção sobre os Direitos da Pessoa com Deficiência, que o define como a "concepção de produtos, ambientes, programas e serviços a serem usados, na maior medida possível, por todas as pessoas, sem necessidade de adaptação ou projeto específico". O desenho universal não excluirá as ajudas técnicas para grupos específicos de pessoas com deficiência, quando necessárias (BRASIL, 2009c).

Bock et al. (2018) afirmam que no Brasil, a construção da educação inclusiva se baseia sobre a premissa da educação especial, sendo pautada sobretudo, com vistas à adequação de ambientes e metodologias voltadas às pessoas com deficiência, utilizando termos legais e ideias implícitas do modelo biomédico. No entanto, vale ressaltar que educação inclusiva e educação especial não são sinônimos. A educação inclusiva contempla a educação especial, porém possui maior amplitude, ao considerar que a escola deve ser um espaço de todos e para todos.

A educação especial, tradicionalmente, configurou-se num sistema paralelo e segregado de ensino, voltado aos alunos com deficiência, distúrbios graves de aprendizagem e/ou de comportamento, altas habilidades ou superdotação. A caracterização do serviço especializado consistia no agrupamento de profissionais, técnicas recursos e metodologias específicas. A partir dos anos 1990, novas demandas e expectativas sociais, aliadas aos avanços científicos e tecnológicos têm contribuído para o ideário da Educação Inclusiva, que diz respeito à responsabilidade dos governos e sistemas escolares com a qualificação de todos os alunos no que se refere aos conteúdos, conceitos, valores e experiências do processo de ensino e aprendizagem escolar reconhecendo, sobretudo, as diferenças individuais (GLAT E BLANCO, 2007).

Bock et al. (2018) ressaltam que as pesquisas que tratam a temática da educação de pessoas com deficiência mantêm o foco no contexto da aprendizagem desses sujeitos e evidenciam a necessidade de romper com barreiras que limitam a

\footnotetext{
${ }^{92}$ A legislação brasileira possui alguns documentos que preveem a construção e/ou adequação de ambientes e utilização da tecnologia considerando o Desenho Universal. Segundo Pletsch et al. (2017) a proposta do desenho universal foi introduzida com o objetivo de apoiar o desenvolvimento de produtos, metodologias, estratégias, práticas e serviços inovadores que possibilitem a autonomia, o bem-estar e a qualidade de vida de pessoas com deficiência.
} 
participação, questionando o lugar das práticas normalizadoras e capacitistas. Diante disso, fazem-se necessários estudos pautados no princípio do Desenho Universal para Aprendizagem com a finalidade de romper com a perspectiva de uma inclusão que ocorra a partir de diagnósticos e "rótulos" para o chamado "estudante da inclusão" (grifos das autoras). Bock et al. ainda enfatizam que esta lógica demarca a diferença centrada em um determinado sujeito e desconsidera a ampla variação de cada aprendiz.

Por meio das análises empreendidas no presente trabalho e diante das dificuldades percebidas na implementação da política de educação especial sob a percepção dos agentes implementadores no município de Corumbá, reiteramos a necessidade de construção de espaços que atendam a diferentes necessidades e que não considere as dificuldades um traço específico do aluno. A configuração dos espaços educativos devem ser (re)pensadas com o objetivo de construir conhecimentos em conjunto, respeitando as diferenças próprias da condição humana.

Valle e Connor (2014) destacam a fala de professores que afirmam que "ainda não tiveram, em suas carreiras no ensino, uma turma em que todos tenham tido o desempenho esperado para a série" (p.72). Os autores enfatizam que eles nunca terão essa situação em suas salas de aula. Diante disso, eles afirmam que acreditar que a homogeneidade exista significa ficar permanentemente desapontado e perder de vista o objetivo do ensino.

Pobre da criança que é considerada como "não adequada" para a educação especial (ou seja, os resultados dos testes indicam inelegibilidade para os serviços) e cujo professor a vê como "não adequada" para a educação geral também. Temos de dar um passo para trás e nos perguntar o que uma educação pública gratuita e adequada para todas as crianças realmente significa (VALLE e CONNOR, 2014 p.72 - 73).

Sob esse ponto de vista, faz-se necessário começar o trabalho a partir da reestruturação das expectativas dos profissionais, sobretudo em relação aos alunos com deficiência. A atuação dos agentes implementadores afeta diretamente o desempenho dos alunos, mas para que isso de fato seja algo positivo é necessário (re)construir a forma como a deficiência é percebida na sociedade e, sobretudo, nos ambientes escolares. 


\section{5 \\ CONSIDERAÇÕES FINAIS}

O presente trabalho buscou verificar como a política da educação especial é implementada na rede municipal de Corumbá/MS a partir da percepção dos agentes implementadores. Como agentes implementadores consideramos os profissionais da secretaria de educação (Núcleo de inclusão escolar e diversidade e CMADIJ), equipe de gestão das escolas e os professores regentes, professores do atendimento educacional especializado e profissionais de apoio, considerados burocratas de médio escalão e burocratas de nível de rua, respectivamente.

A utilização de conceitos de burocracia de médio escalão e burocracia de nível de rua em estudos da área da educação especial consistem em algo ainda não realizado anteriormente. Conforme apontado na justificativa do presente trabalho, as pesquisas do campo da educação especial voltam-se, em sua maioria, para aspectos vinculados à prática docente e formação de professores (Bueno e Souza, 2018).

Os resultados mostraram que a margem de discricionariedade desses agentes é pequena, uma vez que os aspectos relacionados ao capacitismo e as condições infraestruturais das unidades escolares interferem negativamente na implementação da política. As percepções acerca da deficiência e o contexto histórico, que carregam consigo a ideia de que esses sujeitos não apresentam capacidades de aprendizagem, interfere diretamente na maneira como as políticas são implementadas.

Assim, ao abordarmos o histórico das políticas educacionais da educação especial, conforme apresentado no primeiro capítulo verificamos que a história traz consigo a publicização dos serviços educacionais voltados às pessoas com deficiência a partir do sombreamento de atendimentos ofertados por instituições privadas financiadas com recursos públicos. As instituições privadas de caráter assistencial, que por muitos anos foram as principais instituições responsáveis pela escolarização dessas pessoas, ainda atuam fortemente nos atendimentos, como foi possível verificar neste trabalho, ao falarmos sobre o desmonte do CMADIJ. 
A descentralização das políticas educacionais durante a década de 1990 também é um fator que merece destaque. A partir daí os gestores escolares passaram a ter mais "autonomia" em suas atuações, no entanto, as aspas na palavra autonomia demonstram que essa ideia não ocorreu na prática, pois os gestores não receberam as condições necessárias para administrar as escolas.

A pesquisa realizada nos mostrou um pouco a respeito dessa realidade. Diretores que não possuem condições mínimas para atuarem, escolas com infraestrutura precária e com ausência de mobiliário básico, falta de recursos financeiros para realização de reformas e reparos. Situações que levam a equipe de gestão da escola e os professores a se organizarem para conseguirem recursos por meio de ações coletivas como festival de prêmios, rifas, sorteios, entre outros.

No âmbito da secretaria de educação temos o Núcleo de Inclusão Escolar e Diversidade que é responsável pelo Centro Multidisciplinar de Apoio ao Desenvolvimento Infanto-Juvenil (CMADIJ) que conta com assessoras técnicas que realizam o acompanhamento dos atendimentos educacionais dos alunos com deficiência matriculados na rede municipal. O referido centro, criado em 2004, contava inicialmente com dezoito profissionais da área da educação e saúde, sofrendo alterações em sua composição nos anos seguintes, com a retirada dos profissionais que atuavam na saúde. Permanecem no centro, as psicopedagogas, que atualmente são responsáveis por todas as atividades realizadas pelo setor.

Mesmo que os discursos digam que a intervenção é unicamente pedagógica, as profissionais ainda realizam ações pontuais na área da saúde, como orientações a respeito de medicamentos, acompanhamento dos alunos nos atendimentos de saúde em outros locais, visitas domiciliares, sendo estes alguns dos exemplos das atividades realizadas, além das orientações pedagógicas à equipe de gestão das escolas, aos professores do AEE, professores regentes e aos profissionais de apoio. Portanto, o centro conta com uma equipe pequena, que deve dar conta de realizar os atendimentos em toda a rede municipal, incluindo as escolas da zona rural.

Como pano de fundo à implementação da política, temos as percepções dos agentes, que consideram as pessoas com deficiência como incapacitadas para aprender, a educação inclusiva percebida como sinônimo de educação especial e 
os alunos com deficiência considerados como "os alunos de inclusão", retirandose os aspectos amplos de uma educação inclusiva que considera que o ensino deva ser ofertado para todos, sem distinção. Todos esses fatores, somados à naturalização da precarização resultam na situação atual da rede municipal em relação à escolarização dos alunos com deficiência: alto número de retenções nos anos iniciais do ensino fundamental.

O capacitismo, presente nos discursos e nas ações descritas pelos agentes, principalmente em sala de aula, não consideram as especificidades dos alunos, suas capacidades e conferem ao "acolhimento" da escola e de todos os seus atores o sucesso da implementação da política. Importante ressaltar que essas questões não estão presentes na formulação das políticas da educação especial, no entanto, apresentam-se fortemente na sua implementação.

Alunos com dezoito anos que frequentam o segundo ano do ensino fundamental e que não são alfabetizados, alunos que repetem o segundo ano por vários anos seguidos e que ainda assim, não conseguem acompanhar os conteúdos demonstram que a realidade dos alunos é precária, aproximando-se de uma situação de violência simbólica, definida por Pierre Bourdieu como uma violência simbólica. Por trás de tudo isso encontramos uma sucessão de desresponsabilização observada em vários âmbitos, desde a secretaria até a equipe de gestão das unidades escolares. A concepção de violência simbólica, cunhada por Bourdieu, "descreve o processo de imposição da cultura hegemônica sobre culturas "minoritárias", dominadas" (VIEIRA, 2010 p.118). A violência simbólica, no que se refere à prática pedagógica, manifesta-se na metodologia, nas regras e técnicas adotada como dogmas ao não ser flexível, ao reproduzir preconceitos, na privação de direitos, assumindo formas silenciosas, contribuindo para a invisibilidade dos sujeitos (VIEIRA, 2010).

Em relação aos burocratas de nível de rua estes também apresentam pequena margem de discricionariedade, uma vez que o trabalho ocorre em um contexto em que as formações continuadas não são realizadas pela rede, mas apenas reuniões para discussão de casos e repasse de informações e as unidades escolares não possuem estrutura adequada. Somado a isso há também pouca articulação dos professores regentes com os professores do AEE e profissionais de 
apoio. A professora do AEE da Escola II, afirma várias vezes durante a entrevista que a maioria dos profissionais não conhece sua atuação e chegam a afirmar que ela é a psicóloga da escola. Isso nos mostra a percepção também pautada no modelo médico, ainda presente na educação das pessoas com deficiência.

Já as profissionais que possuem formação e longa experiência na área da educação especial (Professora Regente I da Escola II e Professora do AEE I da Escola IX), demonstraram melhor articulação com as profissionais de apoio e professoras do AEE, aparentando ter um olhar voltado para aspectos externos à escola, identificando situações e encaminhando os casos para a equipe de gestão da escola para providências.

Aí percebemos a importância da formação para que o burocrata de nível de rua possa atuar de acordo com a sua discricionariedade. Conhecendo melhor os aspectos externos que podem influenciar na aprendizagem dos alunos, é possível que eles dialoguem com as famílias, apontem possíveis causas, encaminhem para a direção e possibilitem a realização de um trabalho em conjunto que trará benefícios a todos os alunos. Paralelamente, existe a necessidade de uma rede de serviços que integre educação, saúde e assistência, para que esse encaminhamento e atendimento realmente tenha efetividade. No entanto, apenas o fator ligado à formação não é considerado suficiente para que as escolas consigam atuar na perspectiva da educação inclusiva.

Além desses aspectos, não podemos deixar de apontar a importância da construção de um modelo de educação que contemple a aprendizagem de todos, que procure atender às necessidades através da participação ativa dos alunos. Nunes e Madureira (2015) afirmam que a inclusão impõe mudanças importantes no modo de perspectivar o papel e as funções da escola e na maneira de desenvolver as práticas pedagógicas eficazes que garantam a aprendizagem de todos os alunos. Assim, o Desenho Universal para a Aprendizagem constitui uma abordagem curricular que procura ajudar os professores a responder às necessidades de diversos alunos; remover barreiras de aprendizagem; flexibilizar o processo de ensino; permitir aos alunos formas alternativas de acesso e envolvimento na aprendizagem e; reduzir a necessidade de adaptações curriculares individuais (idem). 
Assim, muito mais do que a discricionariedade dos burocratas de médio escalão e de nível de rua, no contexto da educação das pessoas com deficiência é necessário que existam condições para o atendimento de todos os alunos com o objetivo de proporcionar tanto aos alunos com deficiência, quanto aos profissionais, as possibilidades mínimas de um ensino que considere a diversidade humana. É preciso entender que esses sujeitos, durante toda sua história, foram vistos como pessoas incapacitadas, merecedoras apenas da filantropia da sociedade. A partir da mudança desta concepção, ocorre a possibilidade da construção de uma escola que oferte possibilidades de aprendizagem a todos. Assim sendo, entendemos a necessidade de uma alteração profunda, que envolva não só os atendimentos voltados a essas pessoas, mas o contexto em que as escolas estão inseridas, a possibilidade de atuação dos profissionais e as percepções acerca da deficiência. É o que apregoa o Desenho Universal para Aprendizagem, conforme apontado no capítulo IV.

Os resultados nos fazem entender melhor a situação referente aos números apontados pelos microdados do Censo Escolar 2016, que apontavam a retenção de pessoas com deficiência nos anos iniciais do Ensino Fundamental. Isso, possivelmente, acontece pela maneira como a deficiência é percebida, pois é a partir daí, que a política é pensada e implementada.

Outro fator apontado pela pesquisa diz respeito às características de uma política marcada pela descontinuidade. Mudanças frequentes de gestão, possivelmente vinculadas à motivações político-partidárias contribui para que as ações realizadas pela rede municipal não sejam passíveis de continuidade, a exemplo do relato da supervisora II do Núcleo de Inclusão Escolar e Diversidade, ao relatar a perda de recursos ocorrida durante a mudança de uma das gestões da secretaria. Sobre a descontinuidade das políticas educacionais, Saviani (2008) afirma que esta é uma marca da política educacional brasileira, que tem por característica a sucessão de reformas que adiam as metas estabelecidas, tal como a erradicação do analfabetismo, por exemplo ${ }^{93}$.

\footnotetext{
${ }^{93}$ A esse respeito, Saviani (2008) afirma que: "Para enfrentar esse problema, a Constituição de 1988 previu, nas disposições transitórias, que o Poder Público nas suas três instâncias (a União, os estados e os municípios) deveriam, pelos dez anos seguintes, destinar $50 \%$ do orçamento educacional para essa dupla finalidade. Isso não foi feito. Quando esse prazo estava vencendo, o
} 
No âmbito municipal, a situação não é diferente como foi possível observar nos resultados do trabalho em tela: mudanças de gestão que impactam na continuidade das ações e alteração dos atores que iniciam (ao menos a cada quatro anos) uma nova maneira de gerir a política. Muitas vezes sem considerar o que foi construído anteriormente ou até mesmo alterando o que já foi feito para deixar sua "marca" de gestão.

Já no contexto das unidades escolares foi possível perceber a naturalização da precariedade, ao observarmos escolas que não possuíam condições adequadas de funcionamento, grande número de alunos matriculados (independente de possuir ou não deficiência) e poucos elementos que pudessem contribuir para que, tanto a equipe de gestão, quanto os professores realizassem um trabalho que considerasse a diversidade humana presente no ambiente escolar. Tal situação aponta para o fato das políticas educacionais brasileiras não contemplarem as políticas da educação especial em sua plenitude. Como mostramos no capítulo I, tais políticas foram construídas de maneira paralela.

A realização do trabalho, que teve como objetivo verificar a atuação dos agentes implementadores da política de educação especial na rede municipal de Corumbá/MS apresentou importantes aspectos do "chão da escola" que acabam por impactar os resultados de tais políticas. A descontinuidade da política, a desresponsabilização de alguns agentes, a ausência de recursos que contribuem para a precariedade da infraestrutura das escolas, poucas oportunidades de formação, além das percepções ligadas ao capacitismo que permeia toda a história da educação de pessoas com deficiência no Brasil, mostram a necessidade da construção de uma política educacional que contemple de fato as pessoas com deficiência, não como alunos que necessitam apenas de um atendimento

governo criou o FUNDEF, com prazo de mais dez anos para essa mesma finalidade; e a LDB, por sua vez, instituiu a década da educação; seguiuse a aprovação, em 2001, do Plano Nacional de Educação, que também se estenderia por dez anos. No final do ano passado, ao se esgotarem os dez anos do prazo do FUNDEF, foi instituído o FUNDEB, com prazo de 14 anos, ou seja, até 2020. Agora, quando mais da metade do tempo do PNE já passou, vem um novo Plano, o Plano de Desenvolvimento da Educação (PDE) estabelecer um novo prazo, desta vez de quinze anos, projetando a solução do problema para 2.022. Nesse diapasão, já podemos conjecturar sobre um novo Plano que será lançado em 2022 prevendo, quem sabe, mais 20 anos para resolver o mesmo problema" (p.12). 
especializado, mas como atores que possuem suas demandas atendidas em sua plenitude, considerando a oferta de serviços educacionais, de saúde e assistência.

Como sugestões para trabalho futuros, apontamos a necessidade de pesquisas que contemplem a temática das famílias dos alunos com deficiência no que tange à relação família e escola, uma vez que os responsáveis dos alunos com deficiência apresentam um importante papel nas ações voltadas a esses alunos e muitas vezes são responsabilizados pelos resultados apresentados pelos alunos, conforme apontado na presente pesquisa.

Uma outra sugestão diz respeito à estudos que investiguem a aplicação dos preceitos abordados pelo Desenho Universal para a Aprendizagem e sua efetividade para alunos com e sem deficiência.

Ademais, a pesquisa nos mostrou, a influência da percepção dos agentes implementadores em relação às pessoas com deficiência e como isso influencia a implementação da política voltada ao atendimento educacional dessa população. Pesquisas que enfoquem os "panos de fundo", tais como este estudo, são necessárias, pois apontam fatores que, possivelmente, auxiliarão no entendimento da situação atual desses atores: tanto das condições dos agentes implementadores quanto das pessoas com deficiência. 


\section{Referências Bibliográficas}

AGUIAR, L.C., Um legado do século XX para a política educacional do século XXI? A teoria do capital humano. Revista HISTEDBR on-line, Campinas, n.40, p.126-144, dez. 2010.

ALMEIDA, V.L. A inclusão escolar sob a perspectiva do aluno com deficiência matriculado no Ensino Médio. Dissertação de Mestrado. UFMS, 2015.

ARAÚJO FILHO, T.P. Burocratas do nível de rua: uma análise interacionista sobre a atuação dos burocratas na linha de frente do Estado. Áskesis, v.3, n.1, janeiro/julho, 2014 p. 45-57.

ARRETCHE, M. Federalismo e democracia no Brasil: a visão da ciência política norte-americana. São Paulo em perspectiva, v. 15, n. 4, p. 23-31, 2001.

. Relações federativas nas políticas sociais. Educação e Sociedade.,

Campinas , v. 23, n. 80, p. 25-48, Set. 2002 . Available from http://www.scielo.br/scielo.php?script=sci arttext\&pid=S0101-

73302002008000003\&lng=en\&nrm=iso. Disponível em: 20 de maio de 2017.

Federalismo e políticas sociais no brasil: problemas de coordenação e autonomia. In: SARAVIA, E.; FERRAREZI, E., Políticas Públicas, Brasília, ENAP, 2006.

BARBOSA, M.G. Educação, vida precária e capacitação. Educação e Sociedade, Campinas, v. 39, n. 144, p. 584-599, Sept. 2018 . Available from $<$ http://www.scielo.br/scielo.php?script=sci_arttext\&pid=S0101-

$73302018000300584 \& \operatorname{lng}=$ en\&nrm=iso>. Acesso em 27 de janeiro de 2019.

BARRET, S. Implementation studies: time for a Revival? Personal reflections on 20 Years of implementation studies. Public Administration, v. 82, n., 2, 2004.

BENDINELLI, R. C.; PRIETO, R. G.; ANDRADE, S. G. Inclusão escolar, redes de apoio e políticas sociais. Revista Educação Especial, Santa Maria, p. 13-27, mar. 2012. ISSN 1984-686X. Disponível em: <https://periodicos.ufsm.br/educacaoespecial/article/view/4058/3088>. Acesso em: 20 dez. 2018.

BOCK, G.L.K. GESSER, M., NUERNBERG. A.H. Desenho universal para a aprendizagem: a produção científica no período de 2011 a 2016. Revista Brasileira de Educação Especial. Marília, v.24, n.1, p. 143-160, jan-mar. ,2018. 
BONAMINO, A.M.C. O público e o privado na educação brasileira: inovações e tendências a partir dos anos de 1980. Revista Brasileira de História da Educação, n.5 jan/jun. 2003.

BOURDIEU, P.; CHAMPAGNE, P. Os incluídos do interior. In: BOURDIEU, P. et al. A miséria do mundo. Petrópolis: Editora Vozes, 2001.

Compreender. In: BOURDIEU, P. (2008), A miséria do mundo. São Paulo, Vozes.

BRASIL, CONGRESSO NACIONAL. Lei no 4.024 de 20 de dezembro de 1961 - Fixa as Diretrizes e Bases da Educação Nacional. Brasília, 1961. Disponível em: http://www2.camara.leg.br/legin/fed/lei/1960-1969/lei-4024-20-dezembro1961-353722-publicacaooriginal-1-pl.html Acesso em: 19 de outubro de 2016.

Ministério da Educação. Lei Educacional 5.992/71. Fixa Diretrizes e Bases para o ensino de $\mathbf{1}^{\mathbf{0}}$ e $\mathbf{2}^{\mathbf{0}}$ graus, e dá outras providências. Brasília, 1971. Disponível em: <https://www2.camara.leg.br/legin/fed/lei/1970-1979/lei-569211-agosto-1971-357752-publicacaooriginal-1-pl.html> Acesso em: 19 de outubro de 2016.

, CONSTITUIÇÃO (1988). Constituição da República Federativa do Brasil. Brasília, DF: Senado Federal, 1988.

Declaração de Salamanca e Linha de Ação sobre Necessidades Educativas Especiais. Brasília: Coordenadoria Nacional para Integração da Pessoa Portadora de Deficiência, 1994.

Plano Diretor da Reforma do Aparelho do Estado (MARE). Brasília: Câmara da Reforma do Estado, 1995.

, Ministério da Educação. Decreto n. 3.298 Regulamenta a Lei no 7.853, de 24 de outubro de 1989, dispõe sobre a Política Nacional para a Integração da Pessoa Portadora de Deficiência, consolida as normas de proteção, e dá outras providências, Brasília, 1999.

CONSELHO NACIONAL DE EDUCAÇÃO. CÂMARA DE EDUCAÇÃO BÁSICA. CNE/CEB 2/2001, Diretrizes Nacionais para a Educação Especial na Educação Básica. Brasília, 2001.

Ministério da Educação e Cultura. Secretaria de Educação Especial. Projeto Plurianual de implementação da educação inclusiva nos municípios brasileiros: 2003-2006. Brasília: MEC, 2003.

MEC. SEESP. Educação inclusiva: v.2. O município. Brasília: Ministério da Educação, Secretaria de Educação Especial, 2004. 
MEC. SEESP. Educação Inclusiva: direito à diversidade. Documento Orientador. Brasília, 2005. Disponível em: http://portal.mec.gov.br/seesp/arquivos/pdf/orientador1.pdf Acesso em: $14 \mathrm{de}$ março de 2017.

MEC.SEESP. Programa Educação Inclusiva: direito à diversidade. Brasília, 2006. Disponível em: 〈www.mec.gov.br〉 Acesso em: 14 de março de 2017.

O Plano de Desenvolvimento da Educação: razões, princípios e programas. Brasília, MEC, 2007.

MEC/SEESP. Política Nacional de Educação Especial na Perspectiva da Educação Inclusiva. Brasília, 2008 Disponível em: 〈www.mec.gov.br $>$ Acesso em 30 de abril de 2017.

MEC. Decreto $\mathbf{n}^{\circ}$ 6.571 de 17 de setembro de 2008. Dispõe sobre o atendimento educacional especializado, regulamenta o parágrafo único do art. 60 da Lei $n^{\circ} 9.394 / 96$, e acrescenta dispositivo ao Decreto $n^{\circ} 6.253$, de 13 de novembro de 2007. Brasília, 2008a.

CONSELHO NACIONAL DE EDUCAÇÃO. CÂMARA DE EDUCAÇÃO BÁSICA. CNE/CEB 4/2001, de 02 de outubro de 2009. Diretrizes Operacionais para o Atendimento Educacional Especializado na Educação Básica, modalidade Educação Especial. Brasília, 2009.

—. Ministério da Saúde. Atenção à Saúde das Pessoas Ostomizadas. Brasília, 2009a. Disponível em: http://bvsms.saude.gov.br/bvs/folder/atencao_saude_pessoas_ostomizadas.pdf Acesso em: 20 de novembro de 2018.

- Subsecretaria Nacional de Promoção dos Direitos da Pessoa com Deficiência. Comitê de Ajudas Técnicas Tecnologia Assistiva. - Brasília : CORDE, 2009b.

Decreto 6.949 Promulga a Convenção Internacional sobre os Direitos das Pessoas com Deficiência e seu Protocolo Facultativo, assinados em Nova York, em 30 de março de 2007. Brasília, 2009c.

Ministério da Educação. Secretaria de Educação Especial. Manual de orientação: Programa de Implantação de Salas de Recursos Multifuncionais. Brasília, MEC, 2010.

Programa Educação Inclusiva direito à diversidade no contexto da SECADI/MEC. Secretaria de Educação Continuada, Alfabetização, Diversidade e Inclusão, Brasília, junho 2013. 
SNPD. Viver sem Limite - Plano Nacional dos Direitos da Pessoa com deficiência / Secretaria de Direitos Humanos da Presidência da República (SDH/PR) / Secretaria Nacional de Promoção dos Direitos da Pessoa com Deficiência (SNPD) • VIVER SEM LIMITE - Plano Nacional dos Direitos da Pessoa com Deficiência : SDH-PR/SNPD, 2013a.

. Ministério da Educação. Nota Técnica no. 24 - Orientação aos Sistemas de Ensino para a implementação da Lei n 12.764/2012. Brasília, 2013 b.

Lei Federal 13.005, de 25 de junho de 2014. Aprova o Plano Nacional de Educação - PNE e dá outras providências. Brasília, DF, 25. Jun. 2014. Disponível em: < http://www.planalto.gov.br/ccivil_03/_ato20112014/2014/lei/113005.htm> Acesso em: 30 de abril de 2017.

, FUNDO NACIONAL DE DESENVOLVIMENTO DA EDUCAÇÃO. PDDE - Programa Dinheiro Direto na Escola. Brasília, 2017. Disponível em: $<$ http://www.fnde.gov.br/programas/dinheiro-direto-escola/dinheiro-direto-escolaapresentacao> Acesso em: 30 de abril de 2017.

MINISTÉRIO DA SAÚDE. Manual de ambiência dos Centros Especializados em Reabilitação (CER) e das Oficinas Ortopédicas. Brasilia, 2017a. Disponível em: $<$ http://portalarquivos2.saude.gov.br/images/pdf/2017/junho/12/Manual-deAmbiencia-dos-Centros-Especializados-em-Reabilitacao-e-das-Ofi.....pdf $>$ Acesso em: 01 de março de 2019.

MEC. Fundo Nacional de Desenvolvimento da Educação - História. Brasília, 2018. Disponível em: <https://www.fnde.gov.br/acesso-ainformacao/institucional/quem-somos> Acesso em: 20 de dezembro de 2018.

SIMEC - Sistema Integrado de Monitoramento Execução e Controle. Brasília, 2019. Disponível em: 〈http://simec.mec.gov.br/login.php> Acesso em: 10 de janeiro de 2019.

BUENO. J.G.S. As políticas de inclusão escolar: uma prerrogativa da educação especial? In: BUENO, J.G.S.; MENDES, G.M.L.; SANTOS, R.A. (Org) Deficiência e escolarização: novas perspectivas de análise. Araraquara: Junqueira \& Marin; Brasília, DF: Capes, 2008 p.43-63.

$\mathrm{O}$ atendimento educacional especializado (AEE) como programa nuclear das políticas de educação especial para inclusão escolar. Tópicos Educacionais, Recife, v.22, n.1, jan/jun. 2016.

SOUZA, S. B. A constituição do campo da educação especial expressa na Revista Brasileira de Educação Especial - RBEE (1992-2017). Revista Brasileira de Educação Especial., Marília, v.24., Edição Especial, p.33-50, 2018. 
BULL, D., The Anti-Discretion Movement in Britain: Fact or Phantom?' Journal of Social Welfare Law (1980).

BURGSTAHLER, S. Equal Access: universal design os instruction. Do-it, University of Washington, 2008.

CAIADO, K.R.M.; LAPLANE, A.L.F. Programa Educação Inclusiva: direito à diversidade - uma análise a partir da visão de gestores de um município-pólo. Educação e Pesquisa, São Paulo, v.35, n.2, p.303-315, maio/ago, 2009.

CAIDEN, N.; WILDAVISKY, A. Planning and Budgeting in Developing Countries. New York: John Wiley. 1980.

CAMARGO, E. P. Inclusão social, educação inclusiva e educação especial: enlaces e desenlaces. Ciência e Educação (Bauru), v.23, n.1, Bauru, jan-mar, 2017.

CAMARGO, F.P. O Benefício de Prestação Continuada e a inserção do indivíduo com deficiência intellectual no mundo do trabalho. Dissertação de Mestrado, UFMS, 2011.

CAMPBELL, F.K. Disability Harms: exploring internalized Ableism. In: MARSHALL, C.A. et al. Disabilities: insights from across fields and around the world. Greenwood Publishing Group: London, 2009.

CARNEIRO, M. S. C. Reflexões sobre a avaliação da aprendizagem de alunos da modalidade Educação Especial na Educação Básica. Revista Educação Especial (UFSM), v. 25, 2012.

CAPELLA, A.C.N. Perspectivas teóricas sobre o processo de formulação de políticas públicas. In: HOCHMAN, G., ARRETCHE, M., MARQUES, E. (orgs) Políticas Públicas no Brasil. Rio de Janeiro: Editora Fiocruz, 2007.

CAVALCANTE, P. Descentralização de políticas públicas sob a ótica neoinstitucional: uma revisão de literatura. Revista de Administração Pública, v.45, n.6, 2011.

CAVALCANTE, P.L.C., CAMÕES, M.R.S., KNOP, M.N.H. Burocracia de Médio Escalão nos setores governamentais: semelhanças e diferenças. In: CAVAlCANTE, P., LOTTA, G. (orgs). Burocracia de Médio Escalão: perfil, trajetória e atuação. Brasília, ENAP, 2015.

.; LOTTA, G.S.; Burocracia de Médio Escalão: perfil, trajetória e atuação. Brasília, ENAP, 2015.

CAVALCANTI, S. LOTTA, G.S., PIRES, R.R.C. Contribuições dos estudos sobre burocracia de nível de rua. In: PIRES, R., LOTTA, G., OLIVEIRA, V.E. 
Burocracia e políticas públicas no Brasil: interseções analíticas. Brasília: Ipea: Enap, 2018.

COHEN, M.; MARCH, J.; OLSEN, J. A Garbage Can Model of Organizational Choice, Administrative Science Quarterley 17: 1-25. 1972.

CORUMBÁ, Lei no . 1.523/96. Prefeitura Municipal de Corumbá, 1996.

Corumbá, 2003.

CONSELHO MUNICIPAL DE EDUCAÇÃO. Deliberação no $\mathbf{n}^{\mathbf{0}} \mathbf{7 4}$

Decreto no. 128/2004 - Cria a Unidade de Apoio à Inclusão de Portadores de Necessidades Especiais da Rede Municipal de Ensino e dá outras providências, Prefeitura Municipal de Corumbá, 2004.

Lei Complementar $n^{\circ}$. 89/2005 Dispõe sobre o Plano de Cargos e Carreiras da Prefeitura Municipal de Corumbá, cria cargos efetivos, fixa vencimentos e dá outras providências. Corumbá, 2005.

, SECRETARIA MUNICIPAL DE EDUCAÇÃO. Resolução no 023/2007 - Dispõe sobre o funcionamento do CMADJI e dá outras providências, Prefeitura Municipal de Corumbá, 2007.

2009.

Lei Municipal no. 2.091 - Plano Municipal de Educação. Corumbá,

SECRETARIA MUNICIPAL DE EDUCAÇÃO. Lei n.2.264 - Dispõe sobre a gestão democrática do ensino público municipal de Corumbá e fixa regras para a eleição de diretores e do colegiado escolar da rede municipal de ensino. Corumbá, 2012.

Decreto nº 1.141/2013 Estrutura da Administração Direta Municipal de Corumbá. Corumbá, 2013.

2015 .

Deliberação 402/2015 Conselho Municipal de Educação. Corumbá,

APAE de Corumbá é habilitada como Centro Especializado em Reabilitação. 2015a. Disponível em: www.corumba.ms.gov.br/noticias/apae-decorumba-e-habilitada-como-centro-especializado-em-reabilitação/17603 Acesso em: 13 de maio de 2018.

, Lei Municipal no . 2.550. Corumbá, 2016.

Decreto 2.018 de 25 de julho de 2018. Dispõe sobre a reordenação da tipologia das unidades escolares e dos centros de educação infantil da Rede Municipal de Ensino de Corumbá, e dá outras providências. Disponível em: 
http://do.corumba.ms.gov.br/corumba/portal/visualizacoes/pdf/3147\#/p:1/e:3147? find=Decreto\%20n.\%202018 Acesso em 28 de dezembro de 2018.

SECRETARIA MUNICIPAL DE EDUCAÇÃO. Resolução SEMED/ no 082 - Dispõe sobre a organização curricular da Educação Básica do Município de Corumbá - MS para o ano de 2018, e dá outras providências. Corumbá, 2017.

CORRÊA, N.M. A construção do processo de municipalização da educação especial em Campo Grande no período de 1996 a 2004. Dissertação de Mestrado. Universidade Federal de Mato Grosso do Sul, 2005.

COSTA, G.V.L. Os bolivianos em Corumbá-MS: conflitos e relações de poder na fronteira. Mana, vol.21, n.1, Rio de Janeiro, abril, 2015.

CUNILL-GRAU, N. A intersetorialidade nas novas políticas sociais: uma abordagem analítico-conceitual. In: Cadernos de estudos: desenvolvimento social em debate, Brasília, Ministério do Desenvolvimento Social e Combate à Fome, n.26, 2016.

CUNHA, L.A. Ensino Médio e ensino técnico na América Latina: Brasil, Argentina e Chile. Cadernos de Pesquisa. n 111, p. 47-70, dezembro, 2000.

DA SILVEIRA NUNES, S.; SAIA, A.L.; TAVARES, R. E. Educação inclusiva: entre a história, os preconceitos, a escola e a família. Psicologia: ciência e profissão, v. 35, n. 4, p. 1106-1119, 2015.

DALE, R. Globalização e educação: demonstrando a existência de uma "cultura educacional mundial comum" ou localizando uma "agenda globalmente estruturada para a educação"? Educação e Sociedade., Campinas, vol.25, n.87, p. 423-460, maio/ago. 2004.

GANDIN, L.A. Estado, globalização, justiça social e educação: reflexões contemporâneas de Roger Dale. Currículo sem Fronteiras, v.14, n.2, p. 5-16, maio/ago, 2014.

DAVIS, K.C., Discretionary Justice (Louisiana State University Press, Baton Rouge, 1969).

DAVIS, L.J. The disability studies reader. $2^{\circ}$ edition. New York, 2006.

DE OLIVEIRA ESTEVAM, Dimas. A contínua descontinuidade administrativa e de políticas públicas. Seminário de Ciências Sociais Aplicadas, v. 2, n. 2, 2010.

DI GIOVANNI, G. As estruturas elementares das Políticas Públicas. Cadernos de Pesquisa. n.82, Unicamp, 2009. 
DINIZ, D. O que é deficiência. São Paulo: Brasiliense, 2007.

DONNISON, D.V., Against Discretion, New Society, September (1977).

DOS ANJOS, V. P.; DA CRUZ SOUZA, M. A. O atendimento educacional especializado: análise das publicações do PPGE. Revista Educação Especial em Debate, n. 01, p. 52-69, 2016.

DOURADO, L.F., Avaliação do Plano Nacional de Educação 2001-2009: questões estruturais e conjunturas de uma política. Educação e Sociedade., Campinas, v.31, n.112, p.677 - 705, jul-set. 2010.

ÉBERSOLD. S. L'inclusion : du modèle médical au modèle managérial? Reliance, n.16, p.43-50, 2005.

FALEIROS, V.P. A polÃtica social do estado capitalista. 8.ed. São Paulo: Cortez, 2000. p.46-52.

FARIA, J.H. Weber e a Sociologia das Organizações. Revista de Administração, vol. 18(2) - abril/junho, 1983. p. $23-29$.

.; MENEGHETTI, F. Burocracia como organização, poder e controle. Revista de Administração de Empresas, v. 51, n. 5, p. 424-439, 2011.

FARIA, C.A.P. Implementação: ainda o "elo perdido" da análise de políticas públicas no Brasil? Revista Debates, Dossiê Democracia e Políticas Públicas, Porto Alegre, v.6, n.2, p.13-36, maio-ago. 2012.

FARIA, C. . Pierre Bourdieu, Mauricio Tragtenberg e o reprodutivismo na instituição escolar. 2010. (Apresentação de Trabalho/Seminário). Disponível em: http://www.uel.br/projetos/lenpes/pages/arquivos/2010\%20-

\%20FARIA\%20Cintia\%20de.\%20Artigo\%20de\%20Licenciatura.pdf

FERREIRA, J.R. BUENO, J.G.S. Os 20 anos do GT da Educação Especial: gênese, trajetória e consolidação. Revista Brasileira de Educação Especial., Marília, v.17., p.143-170, Maio-Ago., 2011. Edição Especial.

FLORES, A.S. Gestão escolar e educação inclusiva: articulação entre o atendimento educacional especializado e o ensino regular. Dissertação de Mestrado. UNESP: São José do Rio Preto, 2018.

FREIRE, A.O.G VIANA, R.R., PALOTTI, P.L.M. Influência sobre o processo decisório: o que explica o protagonismo da burocracia federal de médio escalão? In: In: CAVAlCANTE, P.; LOTTA, G.S.; Burocracia de Médio Escalão: perfil, trajetória e atuação. Brasília, ENAP, 2015. 
FRIGOTTO, G. Novos fetiches mercantis da pseudo-teoria do capital humano no contexto do capitalismo tardio. In: ANDRADE, Juarez de; PAIVA, Lauriana Gonçalves de (Org.). As políticas públicas para a educação no Brasil contemporâneo: limites e contradições. Juiz de Fora: Ed. UFJF, 2011.

_., CIAVATTA, M. Educação básica no Brasil na década de 1990: subordinação ativa e consentida à lógica do mercado. Educação e Sociedade. 2003, vol.24, n.82, pp.93-130.

GAIO, D.M. A concepção de modernização na política de cooperação técnica entre o MEC e a USAID. Dissertação de Mestrado. Universidade de Brasília, 2008 .

GARCIA, R. M.C. MICHELS, M.H. A política de educação especial no Brasil (1991 - 2011): uma análise da produção do GT15 - educação especial da ANPED. Revista Brasileira de Educação Especial. vol.17, n. especial, Marília, maio - agosto, 2011.

GLAT, Rosana. Educação Inclusiva: Cultura e Contidiano Escolar. 7Letras, 2007.

BLANCO, L.M.V. Educação especial no contexto de uma educação inclusiva. In: GLAT, R. (orgs.) Educação inclusiva: cultura e cotidiano escolar. Rio de Janeiro: 7 letras, 2007.

GIL, J.; PRIETO, R. G. ; SOTO, A. P. O. M.; FREITAS, A. P. R.; GRINKRAUT, A.; ZICHIA, A. C.; BARBOSA, L. M. R.; CURSINO, P. R.; GONZALEZ, R. K. Gestão das políticas de atendimento aos alunos com necessidades educacionais especiais em municípios paulistas. Jornal de Políticas Educacionais, v. 4, p. 15-24, 2010.

GIRAUD, L. Recordando os bombas do Lloyd Brasileiro, cargueiros de ótima qualidade. 2011. Disponível em: <https://portogente.com.br/colunistas/lairegiraud/48243-recordando-os-bombas-do-lloyd-brasileiro-cargueiros-de-otimaqualidade-continuacao> Acesso em: 28 de dezembro de 2018.

GOMES, R. A análise de dados em pesquisa qualitativa. In: MINAYO, M.C.S.(org.). Pesquisa Social: teoria, métodos e criatividade. $21^{\circ}$ edição. Petrópolis, RJ: Vozes, 2002.

GUERREIRO, E.M.B.R. A acessibilidade e a educação: um direito constitucional como base para um direito social da pessoa com deficiência. Revista Educação Especial., Santa Maria, v.25, n.43, p.217-232, maio/ago. 2012. 
HAM, C., HILL, M. The policy process in the modern capitalist state. Harvester Wheatsheaf, Londres, 1993, segunda edição. Tradução de Renato Amorim e Renato Dagnino. Adaptação e Revisão de Renato Dagnino.

HARPUR, P. Sexism and Racism, why not ableism? Calling for a cultural shift in the approach to disability discrimination. Alternative Law Journal. Vol. 34 issue: 3, pages: 163-167. September, 2009.

Cidades@. 2018. Disponível em:

http://www.cidades.ibge.gov.br/xtras/temas.php?lang=\&codmun=500320\&idtema $=16 \&$ search=mato-grosso-do-sul|corumba|sintese-das-informacoes. Acesso em: 20 de outubro de 2018.

2018

Pesquisa Nacional por Amostra de Domicílios Contínua - Educação.

INEP - Instituto Nacional de Pesquisas Educacionais Anísio Teixeira. Censo da Educação Básica 2016. Brasília: MEC/INEP, 2017.

. Inep divulga estudo sobre salário de professor da educação básica. 21

de junho de 2017.2 Disponível em: <
http://portal.mec.gov.br/component/content/article?id=50471>

JACCOUD, L. Pobreza, direitos e intersetorialidade na evolução recente da proteção social brasileira. In: Cadernos de estudos: desenvolvimento social em debate, Brasília, Ministério do Desenvolvimento Social e Combate à Fome, n.26, 2016.

JANNUZZI, G. Algumas concepções de educação do deficiente. Revista brasileira de Ciências do Esporte, Campinas, v.25, n.3, p. 9-25, maio 2004.

A educação do deficiente no Brasil: dos primórdios ao início do século XXI. Campinas, SP: Autores Associados, 2017.

JOAQUIM, R.C.V. A política de educação especial: um estudo sobre sua implementação nas escolas municipais de Campinas no período de 1989 a 2004. Dissertação de mestrado, UNICAMP, 2006.

JUNQUEIRA L.A.; INOJOSA, R. M.; KOMATSU, S. Descentralização e intersetorialidade: na gestão pública municipal no Brasil: a experiência de Fortaleza. Caracas: UNESCO/CLAD, 1998. Série Concurso de Ensayos CLAD.

KASSAR, M.C.M. Ciência e Senso Comum no Cotidiano das Classes Especiais. Campinas, SP: Papirus, 1995.

Reforma do Estado e educação especial: preliminares para uma análise. Revista de Educação PUC-Campinas. Campinas, n.11, p.24-34, novembro 2001. 
; OLIVEIRA, A. D.; SILVA, G. A. M. Inclusão em escolas municipais: análise inicial de um caso. Educação (UFSM), 2007; 32(1), 397-410.

Percursos da constituição de uma política brasileira de educação especial inclusiva. Revista Brasileira de Educação Especial, Marília, v.17, p.41-58, maio/ago, 2011a.

Educação especial na perspectiva da educação inclusiva: desafios da implantação de uma política nacional. Educar em Revista. Curitiba, Brasil, n.41, p.61-79, jul/set, 2011b.

(et al). Educação especial na perspectiva da educação inclusiva em um município de Mato Grosso do Sul. Cadernos Cedes, v. 38, n. 106, 2018.

MELETTI, S.M.F. Análises de possíveis impactos do Programa Educação Inclusiva: Direito à Diversidade. Ciências humanos e sociais em revista. Rio de Janeiro, EDUR, v.34, n.12, p. 49-63, 2012.

REBELO, A. S. O especial na educação, o atendimento especializado e a educação especial. In: VI Seminário Nacional de Pesquisa em Educação Especial, 2011, Nova Almeida, ES. Prática pedagógica na Educação Especial: multiplicidade do atendimento educacional especializado. Porto Alegre: FCAA, 2011. v. 1. p. 1-17.

KINGDON, J. W. Agendas, alternativas and public policies. 2. ed. Ann Arbor, : University of Michigan, 2003.

KLIN, A. Autismo e Síndrome de Asperger: uma visão geral. Revista Brasileira de Psiquiatria., 2006, 28 (Supl I), S3-11.

LACERDA, P.M. De perto, ninguém é anormal: a construção discursiva de identidades, em narrativas de trajetórias escolares longas, de 'pessoas com deficiência'. Tese de doutorado. Pontifícia Universidade Católica do Rio de Janeiro, Rio de Janeiro, setembro de 2006.

LAPLANE, A.L.F. Notas para uma análise dos discursos sobre inclusão escolar. In: GOÉS, M.C.R., LAPLANE, A.L.F. (Orgs.) Políticas e Práticas de Educação Inclusiva. Campinas, SP: Autores Associados, 2013.

LASSWELL, H. La orientación hacia las políticas. En: AGUILAR VILlanueVA, L.F. (Ed.). Estudio de las Políticas Públicas. México: Porrúa. p. 79-103. v. 1., 1951.

LEMME, P. O Manifesto dos Pioneiros da Educação Nova e suas repercussões na realidade educacional brasileira. Revista Brasileira de Estudos Pedagógicos. Brasília, v.86, n.212, p. 163-178, jan/abr. 2005. 
LIBÂNEO, J.C. O dualismo perverso da escola pública brasileira: escola do conhecimento para os ricos, escola do acolhimento social para os pobres. Educação e Pesquisa. São Paulo, v. 38, n.1, p. 13 - 28, 2012.

LIMA, M.F.M. Correção de fluxo na rede pública municipal do Rio de Janeiro (2009-2014): aspectos da política e trajetórias dos alunos. Tese de Doutorado, Pontifícia Universidade Católica do Rio de Janeiro, 2016.

LIMA, L. L.; D’ASCENZI, L. Implementação de políticas públicas: perspectivas analíticas. Revista de Sociologia e Política, v.21, nº 48: 101 - 110, dez. 2013.

LINDBLOM, C. E. Still Muddling, Not Yet Through, Public Administation Review 39: 517-526. 1979

LOBO, J.A. Projetos políticos pedagógicos de escolas da rede municipal de ensino de Corumbá-MS: aproximação às proposições de flexibilização/adaptações curriculares. 2011. Dissertação (Mestrado em Educação) - Universidade Federal de Mato Grosso do Sul.

LOPES, M.M. Perfil e atuação dos profissionais de apoio à inclusão escolar. Dissertação de mestrado. Departamento de Psicologia, Universidade Federal de São Carlos, 2018.

LOTTA, G. S. Implementação de políticas públicas: o impacto dos fatores relacionais e organizacionais sobre a atuação dos burocratas de nível de rua no Programa Saúde da Família. 2010. Tese de Doutorado. Universidade de São Paulo.

Agentes de implementação: uma forma de análises de políticas públicas. Cadernos Gestão Pública e Cidadania, São Paulo, v.19, n.65, jul/dez. 2014.

Burocracia e implementação de políticas de saúde: os agentes comunitários na Estratégia Saúde da Família. Rio de Janeiro: Editora Fiocruz, 2015 .

PIRES, R.R.C.; OLIVEIRA, V.E. Burocratas de médio escalão: novos olhares sobre velhos atores da produção de políticas públicas. In: CAVALCANTE, P.; LOTTA, G.S.; Burocracia de Médio Escalão: perfil, trajetória e atuação. Brasília, ENAP, 2015.

Saber e Poder: Agentes comunitários de saúde: aproximando saberes locais e políticas públicas. Dissertação de Mestrado. Fundação Getúlio Vargas, 2006.

LIPSKY, M. Street-level bureaucracy: dilemas of the individual in public services. Updated ed., 2010. 
MANETTA, A. Dinâmica populacional, urbanização e ambiente na região fronteiriça de Corumbá / Alex Manetta . - - Campinas, SP : [s. n.], 2009.

MARÇAL, T.L. Inclusão no ensino superior: retratos de estudantes com deficiência. Dissertação de Mestrado. Universidade de Aveiro - Departamento de Educação, 2013.

MARÔCO, J. Análise Estatística com o SPSS Statistics. Pero Pinheiro, Portugal. Report Number, 2011.

MARTIN, M.T. Capacitismo (Ableism). In: PLATERO, R.L. et al. (ed.). Barbarismos queer y otras esdrújulas. Barcelona. Ed. Bellaterra, p. 73-81, 2017.

MAYNARD-MOODY, S.; MUSHENO, M. Cops, Teachers and Counselors: Stories from the Front Lines of Public Service. Ann Arbor: The University of Michigan Press, 2003.

MAZZOTTA, M.J.S. Educação especial no Brasil: história e políticas públicas. 5.ed. - São Paulo: Cortez, 2005.

MELO, M.A. Crise federativa, guerra fiscal e "Hobbesianismo municipal" efeitos perversos da descentralização? São Paulo em Perspectiva, v.10, p.3, 1996.

MELO, A.A.S., SOUSA, F.B. A agenda do mercado e a educação no governo Temer. Germinal: Marxismo e Educação em Debate, Salvador, n.9, n. 1, p. 2536, ago. 2017.

MELLO, A.G. Deficiencia, incapacidade e vulnerabilidade: do capacitismo ou a preeminência capacitista e biomédica do Comitê de Ética em Pesquisa da UFSC.Ciência e Saúde Coletiva, Rio de Janeiro, v.21, n.10, p.3265-3276, Out., 2016.

MICHELS, M.H., GARCIA, R.C.G. Sistema educacional inclusivo: conceito e implicações na política educacional brasileira. Caderno Cedes, Campinas, v.34, n.93, p.157 - 173, maio-ago. 2014.

MINAYO, M.C.S Conceito de Avaliação por Triangulação de Métodos. In: MINAYO, M.C.S., ASSIS, S.G., SOUZA, E.R. (orgs). Avaliação por triangulação de métodos: abordagem de programas sociais. Salvador: EDUFBA; Rio de Janeiro: Editora Fiocruz, 2005.

O desafio do conhecimento: pesquisa qualitativa em saúde. São Paulo: Hucitec, 2008.

MIRANDA, T.G. A relação entre o professor da educação especial e da educação comum. Journal of research in special educational needs, v.16, n.1, 2016. 
MOEHLECKE,S. As políticas de diversidade na educação no governo Lula. Cadernos de Pesquisa, v.39, n.137, p.461-487, maio/ago. 2009.

MOTA, M.O. Implementação de políticas públicas educacionais na perspectiva dos agentes burocráticos. Estudos de Avaliação Educacional., São Paulo, v.29, n.72, p.684-709, set/dez, 2018.

NOGUEIRA, F.A. Continuidade e descontinuidade administrativa em governos locais: fatores que sustentam a ação pública ao longo dos anos. Dissertação de Mestrado. Fundação Getúlio Vargas, 2006.

NÓVOA, A. Professores Imagens do futuro presente. EDUCA, Instituto de Educação. Lisboa, julho 2009.

NUNES, C.; MADUREIRA, I. Desenho Universal para a Aprendizagem: Construindo práticas pedagógicas inclusivas. Da investigação às práticas, v. $5, \mathrm{n}$. 2, p. 126-143, 2015.

OLIVEIRA, A.D. Condições de formação continuada do programa educação inclusiva: direito à diversidade. Dissertação de mestrado. Programa de Pósgraduação em Educação da Universidade Federal de Mato Grosso do Sul. Corumbá, 2012.

OLIVEIRA, A.C.P. As relações entre direção, liderança e clima escolar em escolas municipais do Rio de Janeiro. Tese de Doutorado. Pontifícia Universidade Católica do Rio de Janeiro. Rio de Janeiro, 2015.

OLIVEIRA, D.A. Política educacional e a re-estruturação do trabalho docente: reflexões sobre o contexto Latino-americano. Educação e Sociedade., Campinas , v. 28 , n. 99 , p. $355-$

375, Ago. 2007. http://www.scielo.br/scielo.php?script=sci_arttext\&pid=S010173302007000200004\&lng=en\&nrm=iso . Acesso em 31 de janeiro de 2019.

; VIEIRA, L. F.; AUGUSTO, M. H. Políticas de responsabilização e gestão escolar na educação básica brasileira. Linhas críticas, v. 20, n. 43, p. 529$548,2014$.

OLIVEIRA, M.M. Correção de fluxo em uma escola da rede pública municipal do Rio de Janeiro: percepções e discricionariedade dos agentes implementadores. Dissertação de Mestrado. Pontifícia Universidade Católica do Rio de Janeiro. Rio de Janeiro, 2017.

OLIVEIRA, I.C., VASQUES-MENEZES, I. Revisão de literatura: o conceito de gestão escolar. Cadernos de Pesquisa. v.48, n.169, p.876-900, jul/set.2018.

OLIVEIRA, V.E. ABRUCIO, F.L. Burocracia de médio escalão e diretores de escola: um novo olhar sobre o conceito. In: PIRES, R., LOTTA, G., OLIVEIRA, 
V.E. Burocracia e políticas públicas no Brasil: interseções analíticas. Brasília: Ipea: Enap, 2018.

OMOTE, S. Estigma no tempo da inclusão. Revista brasileira de Educação Especial. Marília, set-dez, 2004, v.10, n.3, p. 287-308.

ORGANIZAÇÃO DAS NAÇÕES UNIDAS (ONU), Declaração Universal dos Direitos Humanos. 1948.

Deficiência, 2006.

PADILHA, C.A.T. Educação e Inclusão no Brasil (1985 - 2010). Dissertação de Mestrado, Unicamp, 2014.

A política de educação especial na era Lula (2003-2011): uma opção pela inclusão. Revista HISTEDBR On-line, v. 15, n. 66, p. 160-177, 2015.

PAES DE CARVALHO, C. OLIVEIRA, A.C.P., LIMA, M.F.M. Avaliações externas? Tensões e desafios para a gestão escolar. Estudos em Avaliação Educacional. São Paulo, v.25, n59, p.50-76, set/dez/2014.

; BONAMINO, A., KAPPEL, D. Redes Municipais de Ensino, Planejamento e Resultados Educacionais. Arquivos Analíticos de Políticas Educativas, 19(30), 2011. Acesso em: 20 de novembro de 2018. Disponível em: http://epaa.asu.edu/ojs/article/view/886

.; OLIVEIRA, A.C.P. Gestão escolar, liderança do diretor e resultados educacionais no Brasil. Revista Brasileira de Educação. v.23, 2018.

PEREIRA, J. G. O Patrimônio ambiental urbano de Corumbá-MS: Identidade e Planejamento. 2007. Tese de Doutorado. Universidade de São Paulo.

PERONI, Vera. Política educacional e papel do estado: no Brasil dos anos 1990. São Paulo: Xamã, 2003.

; ADRIÃO, T. Programa Dinheiro Direto na Escola: uma proposta de redefinição do papel do Estado na educação? Brasília: Instituto Nacional de Estudos e Pesquisas Educacionais Anísio Teixeira, 2007.

PINHEIRO, D., DUARTE, S.M.S. Professores do atendimento educacional especializado e de sala de aula regular: articulações e avaliações sobre o ensino e aprendizagem de alunos incluídos. Revista Exitus, v.7, n.1, 2017.

PIRES, R.R.C. Burocracias, gerentes e suas "histórias de implementação": narrativas do sucesso e fracasso de programas federais. 35 $^{\circ}$ Encontro Anual da ANPOCS. Caxambu (MG), 2011. 
PLATT, A. D. O Paradigma Inclusivo Das Políticas Educacionais e o Paradigma Excludente das Políticas Econômicas nos anos 90: o constructo sócio conceitual na normalidade/anormalidade (ou Adequação Social). Tese de Doutorado. Campinas, São Paulo: UNICAMP (Faculdade de Educação), 2004.

PLETSCH, M. D. . A dialética da inclusão/exclusão nas políticas educacionais para pessoas com deficiências: um balanço do governo Lula (2003-2010). Revista teias (UERJ. Online) , v. 12, p. 39-55, 2011.

A escolarização de pessoas com deficiência intelectual no Brasil: da institucionalização às políticas de inclusão (1973-2013). Education Policy Analysis Archives/Archivos Analíticos de Políticas Educativas [online] 2014, 22. Acesso em: 29 de novembro de 2018. Disponível em: 〈http://www.redalyc.org/articulo.oa?id=275031898089>

A escolarização do aluno com deficiência intelectual...apesar do diagnóstico. In: Kassar, Mônica de Carvalho Magalhães; Meletti, Silvia Marcia Ferreira (Org.). Escolarização de alunos com deficiências: desafios e possibilidades. Campinas: Mercado de letras, 2013.p. 243-269.

REBELO, A.S. Os impactos da política de atendimento educacional especializado: análise dos indicadores educacionais de matrículas de alunos com deficiência. Dissertação de mestrado. UFMS, 2012.

A educação especial no Brasil: indicadores educacionais de atendimento especializado (1973-2014). Tese de Doutorado. Programa de Pós-graduação em Educação do Centro de Ciências Humanas e Sociais da Universidade Federal de Mato Grosso do Sul. Campo Grande, 2016.

KASSAR, M.C.M. Escolarização dos alunos da educação especial na política de educação inclusiva no Brasil. Inclusão Social, Brasília, DF, v.11, n.1, p56-66, jul/dez. 2017.

ROLDÃO, M. C. Colaborar é preciso: questões de qualidade e eficácia no trabalho dos professores. Noesis, n. 71, p. 24-29, out./dez. 2007.

ROBERTSON, S.; DALE, R. Pesquisar a educação em uma era globalizante. Educação e Realidade, Porto Alegre, v.36, n.2, p.347-363, maio/ago, 2011.

RODRIGUES, A.P.N. O uso da tecnologia educacional e da tecnologia assistiva na escolarização de estudantes com deficiência no município de Corumbá/MS. Dissertação de Mestrado. UFMS, Campus do Pantanal, 2017.

ROMANELLI, O. O. História da Educação no Brasil (1930/1973). Petrópolis: Editora Vozes. $8^{\circ}$ edição, 1986.

ROSSATO, S.P.M., LEONARDO, N.S.T. A deficiência intelectual na visão de educadores da educação especial: contribuições da Psicologia Histórico-cultural. 
Revista Brasileira de Educação Especial., Marília, v.17, n.1, p.71-86, jan-abr, 2011.

SABATIER, P.; JENKINS-SMITH, H. Policy Change and Learning: The Advocacy Coalition Approach. Boulder: Westview Press. 1993.

SANTOS, B.S. Por uma concepção multicultural de direitos humanos. Revista Crítica de Ciências Sociais. Coimbra/ Portugal, n. 48, p. 11 - 32, junho 1997.

SARAVIA, E. Introdução à teoria da política pública. IN: SARAVIA, E. FERRAREZI, E. (orgs). Políticas Públicas; coletânea. Brasília - ENAP, 2006.

SASSAKI, R. Como chamar as pessoas que têm deficiência? In: SASSAKI, R. Vida independente: história, movimento, liderança, conceito, filosofia e fundamentos. São Paulo: RNR, 2003, p. 12 - 16.

SAVIANI, D. Política educacional brasileira: limites e perspectivas. Revista de Educação PUC-Campinas, Campinas, n.24, p.7-16, junho 2008.

O Plano de Desenvolvimento da Educação: análise do projeto do MEC. Educação e Sociedade, vol. 28, n. 100, outubro, 2007, p. 1231-1255.

SILVA, P. L. B., MELO, M. A. B. O processo de implementação de políticas públicas no Brasil: características determinantes da avaliação de programas e projetos. Núcleo de Estudos de Políticas Públicas - NEPP. Unicamp. Campinas, Caderno no 48, 2000.

SILVA, A.S., CAVALCANTE, T.C.F. A (im)produtividade da educação inclusiva: qual a demanda de inclusão nas escolas públicas. III CONEDU Congresso Nacional de Educação. Natal, RN, 2016.

SOARES, Tufi Machado; FERNANDES, Neimar da Silva; FERRAZ, Mariana Santos Botarro e RIANI, Juliana de Lucena Ruas de. A expectativa do professor e o desempenho dos alunos. Psic.: Teor. e Pesq. [online]. 2010, vol.26, n.1, pp.157-170. ISSN 0102-3772

SODRÉ, A.C.A.; ALVES, M.F.C. Relação entre Emendas Parlamentares e Corrupção Municipal no Brasil: estudo dos relatórios do programa de fiscalização da Controladoria-geral da União. ANPAD. Curitiba, v.14, n.3, art.2.

SOUSA, K.C. A formação docente para a educação especial e a prática profissional do professor. Dissertação de Mestrado, Universidade do Porto, 2017.

SOUZA, C. Políticas públicas: uma revisão da literatura. Sociologias. Porto Alegre, ano 8, no 16, jul/dez, 2006, p. $20-45$. 
SOUZA, F.F. Políticas de educação inclusiva: análise das condições de desenvolvimento de alunos com deficiência na instituição escolar. Tese de Doutorado. Faculdade de Educação, UNICAMP, 2013.

SOUZA, D.B. Avaliações finais sobre o PNE 2001-2010 e preliminares do PNE 2014-2024. Estudos em Avaliação Educacional. São Paulo, v.25, n.59, p.140170, set/dez, 2014.

SPINK, P. Continuidade e descontinuidade em organizações públicas: um paradoxo democrático. Cadernos FUNDAP. São Paulo, ano 7, n.13, p.57-65 abril, 1987.

UNESCO. Declaração de Salamanca e Enquadramento da Acção na Área das Necessidades Educativas Especiais. Lisboa: Instituto de Inovação Educacional, 1994.

VALLE, J.W., CONNOR, D.J. Ressignificando a deficiencia: da abordagem social às práticas inclusivas na escola. Porto Alegre: AMGH, 2014.

VIANNA, M.A. et.al. A importância do casario do porto de Corumbá como patrimônio histórico cultural no desenvolvimento turístico de Mato Grosso do Sul. Multitemas. n.27, jun. 2002.

VICTOR, S.L.; OLIVEIRA, I.M. Trabalho docente e formação: o que dizem os professores da educação especial? Revista Profissão Docente online, Uberaba, v.17, n.36, p.41-54, jan-jul, 2017.

VIEIRA, S.C.A. Educação, violência e o paradoxo inclusão/inclusão. In: PONTES, R. N.; CRUZ, C.R.R. (orgs.) Educação Inclusiva e violência nas escolas. Belém, Unama, 2010.

ZERBATO, A.P. MENDES, E.G. Desenho universal para a aprendizagem como estratégia de inclusão escolar. Educação Unisinos. 22(2): 147-155, abril-junho, 2018.

WILDAVSKY, A. The Policy of Budgetary Process. Boston: Little and Brown, $2^{a}$ edição. 1992. 


\section{7}

\section{ANEXOS}

\section{Anexo 1. Questionário Informativo}

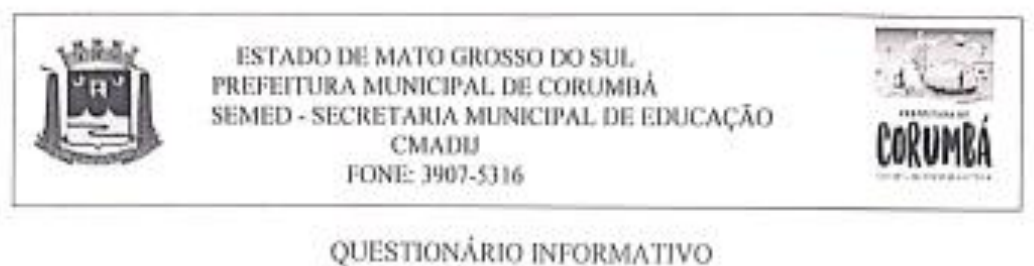

Nonte doAlime :

Data de Nascimento:

Nome da MSe:

Nome do Pai:

Ou Responsaivel :

Enderç̧o do aluno:

Telefone do aluno:

Escola:

Scrie:

Periodo:

Repetente (desde que ano):

I - Motivo do encaminhamento (explicar com detalhes as principais dificuldades do aluno em sala de aula)

I1-Responda detalhadamente as questôes abaixo:

i) Procedimentos pedagógico utilizados com o altmo: 


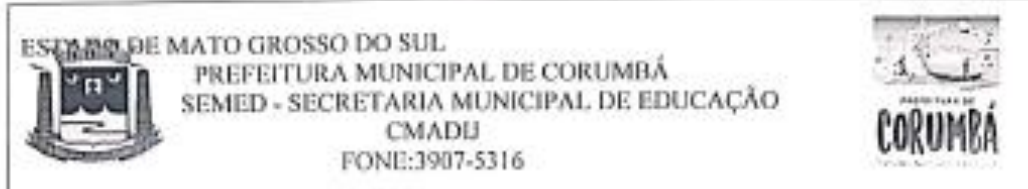

c)Informaçōes sobre a interaçto familia/escola/aluno:

d) Dificuldades/preocupaçס̄es enquanto professor para atingir os seus objetivos:

III-Existe necessidade de adaptaça curricular e'ou acessibilidade no àmbito escolar e familiar?Quais?

Data

Nome do (a) Professar (a)

Por extenso

Nome do (2) Cocrdenador(2)

Por extenso 


\section{Anexo 2.}

Decreto Municipal 2.018 de 25 de julho de 2018.

I - CRITÉRIOS E VARIÁVEIS DE PONTUAÇÃO DAS UNIDADES ESCOLARES

\begin{tabular}{|c|c|c|}
\hline CRITÉRIOS & VARIÁVEIS & PONTUAÇÄO \\
\hline \multirow{6}{*}{$\begin{array}{l}\text { 1. NÚMERO DE ALUNOS } \\
\text { MATRICULADOS }\end{array}$} & Até 250 & 1 \\
\hline & De 251 a 500 & 2 \\
\hline & De 501 a 750 & 3 \\
\hline & 751 a 1000 & 4 \\
\hline & 1001 a 1250 & 5 \\
\hline & Acima de 1250 & 6 \\
\hline \multirow[t]{4}{*}{ 2. ETAPA DE ENSINO } & Educação Infantil - Creche & 1 \\
\hline & Educação Infantil - Pré-escolar & 1 \\
\hline & Ensino Fundamental - Anos iniciais & 1 \\
\hline & Ensino Fundamental - Anos finais & 1 \\
\hline \multirow{4}{*}{$\begin{array}{l}\text { 3. MODALIDADE DE } \\
\text { ENSINO -EJA }\end{array}$} & Até 70 alunos & 0,5 \\
\hline & De 71 a 140 alunos & 1 \\
\hline & De 141 a 280 alunos & 1,5 \\
\hline & Acima de 280 alunos & 2 \\
\hline \multirow[t]{2}{*}{ 4. LOCALIZAÇÃO } & Urbana & 1 \\
\hline & Rural & 2 \\
\hline \multirow{4}{*}{$\begin{array}{l}\text { 5. NÚMERO DE } \\
\text { EXTENSÕES }\end{array}$} & 1 & 0,25 \\
\hline & 2 & 0,5 \\
\hline & 3 & 0,75 \\
\hline & Acima de 3 & 1 \\
\hline
\end{tabular}




\section{8}

\section{APÊNDICES}

\section{Apêndice 1.}

Histórico das ações do governo federal voltadas à Educação Especial. 
Quadro I. Histórico das ações do governo federal voltadas à Educação Especial de 1973 a 2011.

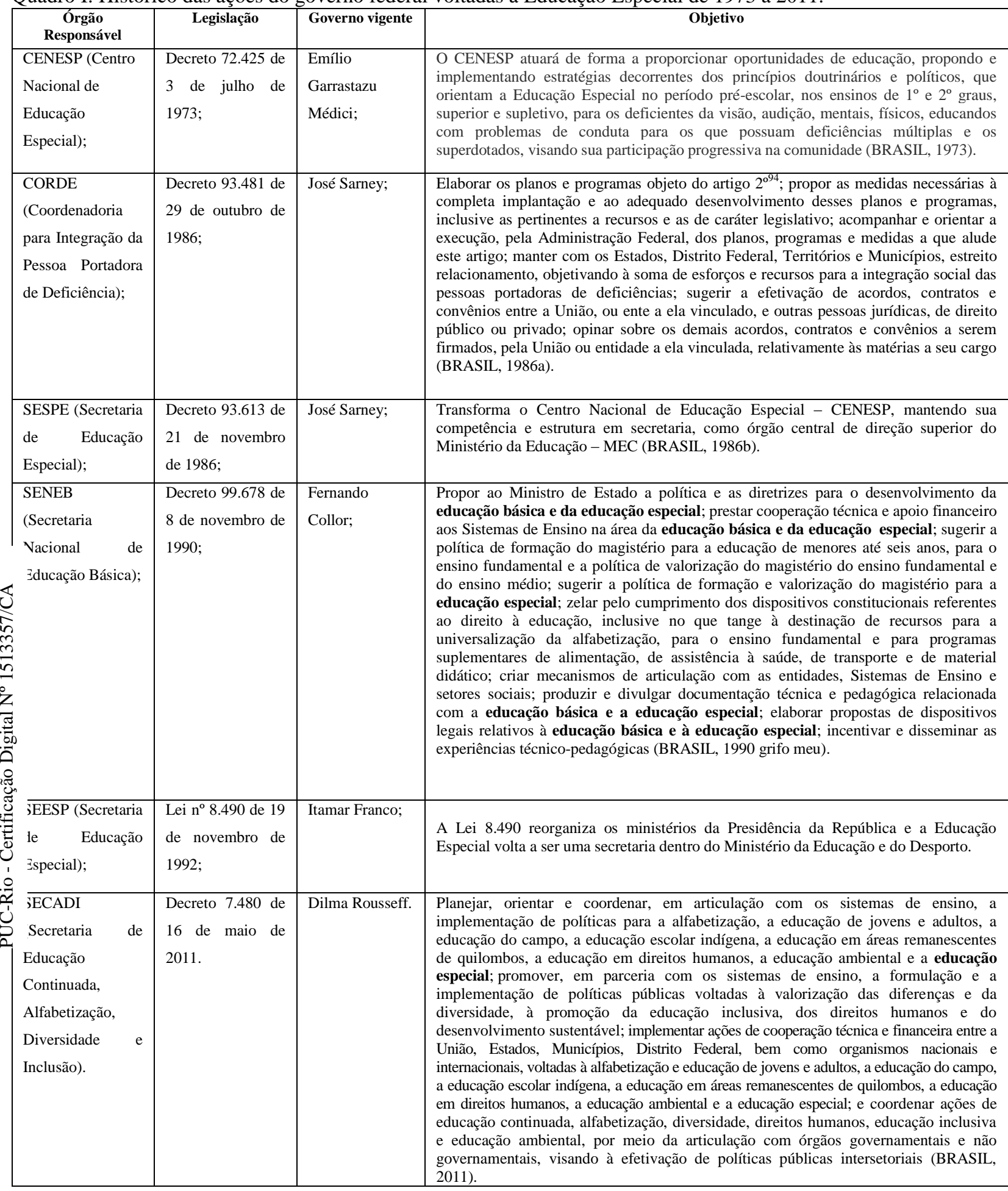

${ }^{94}$ Art. $2^{\circ}$ A Administração Federal atuará, na execução deste ato, integradamente, sob coordenação única, seguindo planos e programas, de prazos e objetivos determinados, aprovados pelo Presidente da República (BRASIL, 1986). 


\section{Apêndice 2.}

Termo de Consentimento Livre e Esclarecido

TERMO DE CONSENTIMENTO LIVRE E ESCLARECIDO

Você está sendo convidado(a) como voluntário(a) a participar do estudo O papel do gestor escolar nas políticas públicas da educação especial e que tem como objetivo investigar qual o papel do gestor escolar na implementação das políticas públicas da educação especial no município de Corumbá/MS. O projeto integra a pesquisa institucional "Liderança, Colaboração Docente e Qualidade da Educação em Diferentes Contextos Organizacionais" do grupo de pesquisa GESQ - Gestão e Qualidade da Educação - coordenado pela Prof ${ }^{a}$. Dr ${ }^{\mathrm{a}}$. Cynthia Paes de Carvalho da PUC-Rio que conta com a autorização da Câmara de Ética em Pesquisa da PUC-Rio.

\section{PARTICIPAÇÃO NO ESTUDO}

A sua participação no referido estudo será responder ao questionário do estudo $\mathbf{O}$ papel do gestor escolar nas políticas públicas da educação especial que contém perguntas sobre a atuação, formação e experiência como diretor de uma unidade escolar.

\section{PROCEDIMENTO}

O questionário será entregue ao diretor da unidade escolar e será recolhido pela pesquisadora após seu preenchimento. Participarão da pesquisa todas as escolas urbanas da rede municipal de Corumbá/MS.

\section{RISCOS E BENEFÍCIOS}

Todos os dados pessoais serão mantidos em sigilo, sendo tratados estatisticamente sem identificação dos respondentes. Há a possibilidade, entretanto, de algum tipo de constrangimento ao abordar temas relacionados à atuação do diretor. Todos os procedimentos levarão este risco em conta, respeitando os envolvidos e a sua escolha em não responder qualquer questão formulada. Os resultados da pesquisa contribuirão com as pesquisas do campo da Educação Especial e poderão subsidiar pesquisas futuras.

\section{SIGILO E PRIVACIDADE}

Nós pesquisadores garantiremos a você que sua privacidade será respeitada, ou seja, seu nome ou qualquer outro dado ou elemento que possa, de qualquer forma, lhe identificar, será mantido em sigilo. Nós pesquisadores nos responsabilizaremos pela guarda e confidencialidade dos dados, bem como a não exposição dos dados de pesquisa.

\section{AUTONOMIA}

Nós lhe asseguramos a assistência durante toda pesquisa, bem como garantiremos seu livre acesso a todas as informações e esclarecimentos adicionais sobre o estudo e suas consequências, enfim, tudo o que você queira saber antes, durante e depois de sua participação. Também informamos que você pode se recusar a participar do estudo, ou retirar seu consentimento a qualquer momento, sem precisar justificar, e de, por desejar sair da pesquisa, não sofrerá qualquer prejuízo. 


\section{RESSARCIMENTO E INDENIZAÇÃO}

Caso tenha qualquer despesa decorrente da participação nesta pesquisa, tais como transporte, alimentação entre outros, haverá ressarcimento dos valores gastos.

De igual maneira, caso ocorra algum dano decorrente de sua participação no estudo, você será devidamente indenizado, conforme determina a lei.

\section{CONTATO}

Os pesquisadores envolvidos com o referido projeto são Flávia Pedrosa de Camargo e Cynthia Paes de Carvalho e com eles você poderá manter contato pelo telefone (67) 9 9223-3386 ou pelos emails flaviacamargo@yahoo.com.br ou cynthiapaesdecarvalho@puc-rio.br

O Comitê de Ética em Pesquisa em Seres Humanos (CEP) é composto por um grupo de pessoas que estão trabalhando para garantir que seus direitos como participante de pesquisa sejam respeitados. Ele tem a obrigação de avaliar se a pesquisa foi planejada e se está sendo executada de forma ética. Se você achar que a pesquisa não está sendo realizada da forma como você imaginou ou que está sendo prejudicado de alguma forma, você pode entrar em contato com o Comitê de Ética em Pesquisa da PUC Rio pelo email posedu@puc-rio.br .

\section{DECLARAÇÃO}

Declaro que li e entendi todas as informações presentes neste Termo de Consentimento Livre e Esclarecido e tive a oportunidade de discutir as informações deste termo. Todas as minhas perguntas foram respondidas e eu estou satisfeito com as respostas. Entendo que receberei uma via assinada e datada deste documento e que outra via assinada e datada será arquivada pelo pesquisador responsável do estudo.

Enfim, tendo sido orientado quanto ao teor de todo o aqui mencionado e compreendido a natureza e o objetivo do já referido estudo, manifesto meu livre consentimento em participar, estando totalmente ciente de que não há nenhum valor econômico, a receber ou a pagar, por minha participação.

\begin{tabular}{|l|l|}
\hline \multicolumn{2}{|l|}{ Dados do participante da pesquisa } \\
\hline Nome: & \\
\hline Telefone: & \\
\hline e-mail: & \\
\hline
\end{tabular} Corumbá, ___ de___

\footnotetext{
Assinatura do participante da pesquisa

Assinatura do Pesquisador
}

\section{USO DE IMAGEM E/OU ÁUDIO}

Autorizo o uso do meu áudio para fins da pesquisa, sendo seu uso restrito para a realização desta pesquisa. 


\section{Apêndice 3.}

Questionário aplicado às direções e coordenações das escolas. 


\section{Eธ}

\section{Pesquisa: “GESTÃO DA ESCOLA, CLIMA ESCOLAR E DESEMPENHO DOS ALUNOS: QUAIS AS RELAÇÕES?”}

Convidamos o/a Sr./Sra. Diretor/a a participar de nossa pesquisa, através do preenchimento deste questionário.

Este trabalho integra a pesquisa "Gestão e Qualidade do Ensino na Educação Básica" do grupo de pesquisa Gestão e Qualidade da Educação - GESQ. Para questionamentos, dúvidas ou relato de algum acontecimento os pesquisadores poderão ser contatados a qualquer momento (gesqpucrio@gmail.com). Sua colaboração será de grande importância para nós. Asseguramos a confidencialidade das informações que nos serão fornecidas. Os dados serão utilizados somente para fins científicos, sem identificação de respondentes individuais ou das escolas em que atuam. Apenas para efeito de controle da quantidade de respondentes por instituição escolar, solicitamos que registre abaixo o nome da escola em que recebeu o presente convite para participar da pesquisa e assinale sua concordância com esta participação.

1. Nome da escola:

2. Declaro estar ciente do exposto e desejo contribuir para esta pesquisa:

( ) $\operatorname{Sim} ;$ ( ) Não

3. Data do preenchimento: direção escolar:

\begin{tabular}{|c|c|c|c|c|}
\hline & $\begin{array}{l}\begin{array}{l}\text { Frequente- } \\
\text { mente }\end{array} \\
\text { mats }\end{array}$ & $\begin{array}{l}\text { Algumas } \\
\text { vezes }\end{array}$ & $\begin{array}{l}\text { Rara- } \\
\text { mente }\end{array}$ & Nunca \\
\hline 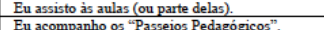 & (1) & (1) & $(1)$ & $(1)$ \\
\hline $\begin{array}{l}\text { Lu acompanho os "Passelos Pedagogageos". } \\
\text { Eu acompanho a aplicação de provas. }\end{array}$ & ( ) & ( ) & () & ( ) \\
\hline $\begin{array}{l}\text { Eu dou sugestões aos professores sobre como eles } \\
\text { podem melhorar suas aulas. }\end{array}$ & ( ) & ( ) & ( ) & ( ) \\
\hline $\begin{array}{l}\text { Eu dialogo com os professores sobre of } \\
\text { problemas gue surgem em suas turmas. }\end{array}$ & ( ) & ( ) & ( ) & ( ) \\
\hline $\begin{array}{l}\text { Eu informo os professores sobre possiveis formas } \\
\text { de ampliarem sua formaçâ para o trabalho na } \\
\text { escola. }\end{array}$ & ( ) & ( ) & ( ) & ( ) \\
\hline Eu dou aulas quando algum professor falta. & ( ) & ( ) & $(\mathrm{s})$ & $(\mathrm{)}$ \\
\hline $\begin{array}{l}\text { Eu campompanho a escolha do material didático } \\
\text { adotado pelos professores na escola. }\end{array}$ & ( ) & ( ) & ( ) & ( ) \\
\hline $\begin{array}{l}\text { Eu converso com os professores sobre } \\
\text { desempenho de seus alunos nas avaliacóes }\end{array}$ & ( ) & ( ) & ( ) & ( ) \\
\hline
\end{tabular}

desempenho de seus alumos nas avaliaçóes

( ) Até um ano.

) Até um ano.
Entre 1 e 3 anos.

Entre 1 e 3 anos.
Mais de 3 anos.

Não possuo experiência.

6. Você possui formação na ảrea da educação especial? a ( ) sim b. ( ) não 6. Você possui formação na área da educação especial? a. ( ) $\operatorname{sim}$ b. ( ) não
7. Você recebe informações/materiais sobre as politicas públicas voltadas às pessoas

com deficiência?

( ) $\mathrm{Sim}$, recebo da Secret

) Sim, recebo do MEC.
Não recebo, porém busco essas informações/materiais por conta própria

Não recebo, porém busco essas informações/mater

8. Como você avalia a sua atuaçã̃o no resultado das politicas públicas da educação?

8. Como você avalia a sua atuação no resultado das politicas públicas
( ) não considero que minha atuação seja importante nos resultados.

( ) não considero que minha atuação seja importante nos resultados. politicas.

politicas.

( ) minha atuação é tão importante quanto a atuação da minl

( ) minha atuação é determinante no resultado das politicas. 9. Qual é a principal estratégia que você utiliza para avaliar o traballo desenvolvido pelos professores?

( ) Observo as aulas. ( ) Discuto sobre o desempenho do professor com o Coordenador Pedagógico e o

Diretor Adjunto.
( ) Levo em consideração comentários feitos pelas familias dos alunos.

( ) Levo em consideração os comentários feitos pelos alunos.

( ) Considero as ponderações feitas pela $\mathrm{CRE} / \mathrm{SME}$.

10. Sobre o seu trabalho na direção desta escola, marque qual é o seu nivel de concordância com cada uma das afirmativas abaixo

\begin{tabular}{|c|c|c|c|c|c|c|c|}
\hline & $\begin{array}{c}\text { Discor- } \\
\text { dot tort- } \\
\text { mente } \\
\text { ment }\end{array}$ & & & & & & $\begin{array}{c}\text { Concor- } \\
\text { do tot- } \\
\text { mente } \\
\text { ment }\end{array}$ \\
\hline $\begin{array}{l}\text { Sinto-me satisfeito (a) com as } \\
\text { relaçōes estabelecidas no } \\
\text { meu local de trabalho }\end{array}$ & ( ) & ( ) & ( ) & ( ) & ( ) & ( ) & ( ) \\
\hline $\begin{array}{l}\text { As demandas de trabalho na } \\
\text { direcão escolar são razoáveis. }\end{array}$ & ( ) & () & ( ) & ( ) & ( ) & ( ) & () \\
\hline $\begin{array}{l}\text { Sinto-me estressado (a) com } \\
\text { o volume de demandas que o } \\
\text { trabalho da direção escolar } \\
\text { me exige. }\end{array}$ & ( ) & ( ) & ( ) & ( ) & ( ) & ( ) & ( ) \\
\hline $\begin{array}{l}\text { Sinto-me insatisfeito (a) com } \\
\text { a irregalaridade da rotina e } \\
\text { com as constantes mudancas } \\
\text { cue interferem na gestâ } \\
\text { quescolar. }\end{array}$ & () & ( ) & ( ) & ( ) & () & () & ( ) \\
\hline $\begin{array}{l}\text { Eu não tenho o mesmo } \\
\text { entusiasmo que eu tinha } \\
\text { quando comecei a trabalhar } \\
\text { na direção escolar. }\end{array}$ & ( ) & ( ) & () & ( ) & () & () & ( ) \\
\hline $\begin{array}{l}\text { Sinto-me frustrado (a) pelo } \\
\text { pouco controle e baixa } \\
\text { interferência que tenho sobre } \\
\text { os projetos encaminhados } \\
\text { pela CRE/SME para a escola. }\end{array}$ & ( ) & ( ) & ( ) & ( ) & () & () & () \\
\hline $\begin{array}{l}\text { Os professoores desta escola } \\
\text { gostam de trabalhar aqui, eu } \\
\text { os descreveria como um } \\
\text { grupo satisfeito. }\end{array}$ & ( ) & ( ) & ( ) & ( ) & () & ( ) & () \\
\hline
\end{tabular}

\begin{tabular}{|c|c|c|c|c|c|c|c|}
\hline $\begin{array}{l}\text { Sinto-me pouco apoiado (a) } \\
\text { em relação aos recursos } \\
\text { financeiros e pessoais } \\
\text { necessários para manter o } \\
\text { pleno funcionamento da }\end{array}$ & ( ) & ( ) & ( ) & ( ) & () & ( ) & ( ) \\
\hline $\begin{array}{l}\text { Sinto-me satisfeito (a) com as } \\
\text { relaçōes estabelecidas no } \\
\text { meul local de thatho }\end{array}$ & ( ) & ( ) & ( ) & ( ) & ( ) & ( ) & ( ) \\
\hline
\end{tabular}

relaçés est estabelecidas
meu local de trabalho

11. Entre os aspectos abaixo, com qual você gasta mais do seu tempo de trabalho na escola?

( ) Gestão de pessoal (administração das relações entre professores e entre funcionários, controle de faltas e licenças, etc.)

( ) Gestão administrativa (prestação de contas, coleta de orçamentos, organização de

( ) Aspectos pedagógicos (discussão sobre currículo, metodologia de ensino, avaliação de desempenho dos alunos, disciplina/comportamento dos alunos)

( ) Relações externas (reuniões com pais, reuniões na CRE/SME, organização e monitoramento de parcerias)

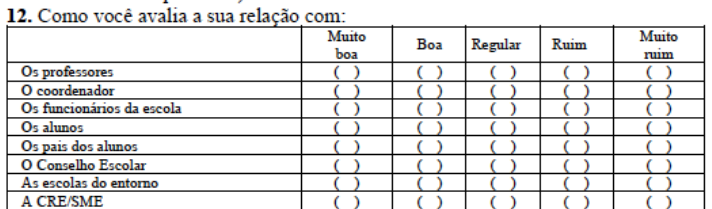

\begin{tabular}{l} 
As escolas do e \\
\hline A CRE/SME \\
\hline
\end{tabular}

13. Como você avalia os seguintes aspectos da sua escola:

\begin{tabular}{|c|c|c|c|c|c|}
\hline & Muito & Boa & Regular & Ruim & $\begin{array}{c}\text { Muito } \\
\text { num }\end{array}$ \\
\hline A convivência entre as pessoas & $\frac{\text { ood }}{(2)}$ & $(1)$ & $(1)$ & $(\mathrm{C})$ & $(1)$ \\
\hline Disciplina/comportamento dos alunos & $(1)$ & $(1)$ & (I) & (1) & $(1)$ \\
\hline Relação dos professores com os alunos & $(1)$ & $(1)$ & (I) & $(2)$ & $(1)$ \\
\hline $\begin{array}{l}\text { Relação entre os professores de uma forma } \\
\text { geral }\end{array}$ & ( ) & ( ) & ( ) & ( ) & ( ) \\
\hline $\begin{array}{l}\text { Relação entre os professores e a } \\
\text { coordenação pedagógica }\end{array}$ & ( ) & ( ) & ( ) & ( ) & ( ) \\
\hline Relação entre os professoreses e a direção & $(\mathrm{C})$ & $(\mathrm{C})$ & ( ) & ( ) & ( ) \\
\hline Relação entre os alunos e os funcionários & $(1)$ & $(1)$ & (1) & () & (1) \\
\hline
\end{tabular}

Relação entre os alunos e os funcionáno

14. Quantos alunos com deficiência desta escola você acredita que chegarão

( ) Todos ou quase todos.

Um pouco mais da metade.

Um pouco menos da meta

Muito poucos.

15. Como o aluno com defíciência é identificado na escola?

( ) A informação e fornecida pela familia na matricula.

( A informação é fornecida pela familia após o inicio das aulas e não no ato da matricula.

( ) $\mathrm{O}$ (a) professor(a) observa em sala de aula e informa a gestão da escola

A escola nunca recebeu alunos com deficiência.

16. Você pretende continuar na direção desta escola nos próximos anos?

16. Voce pretende $\operatorname{Sim}($ ) Não

Registre os motivos que o/a levaram a esta decisão:

17. Qual a expectativa da escola em relação ao(s) aluno(s) com deficiência matriculado(s) atualmente:

( ) Que o(s) aluno(s) acompanhe(m) a turma;

Que ele consiga acompanhar os conteúdos no tempo dele, mesmo que não Q

Que ele não acompanhe os conteúdos, mas tenha a oportunidade de socialização;

( Acredito que o aprendizado no caso desses alunos não seja possivel. 
Geo

\section{Pesquisa: "GESTÃo DA ESCOLA, CLIMA ESCOLAR E DESEMPENHO DOS ALUNOS: QUAIS AS RELAÇÕES?"}

18. Vocês receberam os Referenciais do Programa Educação Educação Inclusiva: direito à diversidade? Caso sim, como utilizam?

( ) não recebemos

( ) recebemos e disponibilizamos para todos os profissionais da escola, independente de solicitação

( ) recebemos e só disponibilizamos quando alguém solicita

( ) recebemos e está arquivado na escola

19. Caso tenha feito ensino superior, em que tipo de instituição se graduou?

( ) pública

20. Qual é o seu grau máximo de escolarização concluida?

( ) ensino fundamental

( ) ensino médio

( ) curso normal de nivel médio

( ) ensino médio técnico

( ) curso normal de nivel superior

( ) ensino superior

( ) pós-graduação especialização

( ) mestrado

doutorado

1. Você é: a. ( ) Homem; b. ( ) Mulher

22. Marque a opção que determina a sua faixa etária:

( ) Até 24 anos ( ) De 40 a 49 anos
( )

$\begin{array}{ll}\text { () De } 25 \text { a } 29 \text { anos } & \text { ( ) De } 50 \text { a } 54 \text { anos }\end{array}$

$\begin{array}{ll}\text { () De } 30 \text { a } 39 \text { anos } & \text { ( ) } 55 \text { anos ou mais. }\end{array}$

23. Caso tenha feito ensino superior, você se graduou em curso de:

( ) pedagogia

( ) outra licenciatura

24. Você concluiu algum curso de qualificação na área de gestão escolar/educacional?

a. ( ) sim; b. ( ) não.
25. Você jả trabalhou como professor regente de turma na educação básica? a. ( ) não; b. ( ) sim. Por quantos anos?

26. Há quantos anos você trabalha como diretor escolar?

( ) 5 anos ou menos ( ) 16 a 20 anos

( ) 6 a 10 anos

( ) mais de 20 anos

( ) 11 a 15 anos

27. Há quantos anos você traballha como diretor nesta escola?

$\begin{array}{ll}\text { ( ) } 5 \text { anos ou menos } & \text { ( ) } 16 \text { a } 20 \text { anos }\end{array}$

( ) 6 a 10 anos ( ) mais de 20 anos

( ) 11 a 15 anos

28. De que forma foi escollido para o cargo atual de diretor escolar?

() indicação () concurso

( ) eleição ( ) escollha através de banca

( ) eleição e seleção ( ) outro. Especifique:

29. Qual a sua carga horária semanal de trabalho?

( ) até $20 \mathrm{~h}$

( ) mais de $40 \mathrm{~h}$

30. Em sua opinião, qual é o maior desafio do trabalho na direção escolar?

31. Agradecemos a sua participação. Caso queira registrar algum comentário sobre este questionário ou acrescentar alguma informação que julgue importante, utilize o espaço abaixo: 
Apêndice 4.

Questionário aplicado aos professores das unidades escolares. 


\section{6es}

\section{Pesquisa: “GESTÃo DA ESCOLA, CLIMA ESCOLAR E DESEMPENHO DOS ALUNOS: QUAIS AS RELAÇÕES?”}

Convidamos o/a Sr./Sra. Professor/a a participar de nossa pesquisa, através do preenchimento deste questionário.

Este trabalho integra a pesquisa "Gestão e Qualidade do Ensino na Educação Básica" do grupo de pesquisa Gestão e Qualidade da Educação - GESQ. Para questionamentos, dúvidas ou relato de algum acontecimento os pesquisadores poderão ser contatados a qualquer momento (gesqpucrio@gmail.com). Sua colaboração será de grande importância para nós. Asseguramos a confidencialidade das informações que nos serão fornecidas. Os dados serão utilizados somente para fins cientificos, sem identificação de respondentes individuais ou das escolas em que atuam. Apenas para efeito de controle da quantidade de respondentes por instituição escolar, solicitamos que registre abaixo o nome da escola em que recebeu o presente convite para participar da pesquisa e assinale sua concordância com esta participação.

1. Nome da escola:

2. Declaro estar ciente do exposto e desejo contribuir para esta pesquisa

( ) $\mathrm{Sim}$; ( ) Não

3. Data do preenchimento:

( ) Educação infantil.

( ) Anos iniciais do ensino fundamental $\left(1^{\circ}\right.$ ao $5^{\circ}$ ano)

( ) Anos finais do ensino fundamental $\left(6^{\circ}\right.$ ao $9^{\circ}$ ano)

( ) Mais de um segmento.

5. Você possui experiência na Educação Especial?

( ) Até um ano.

( Entre 1 e 3 anos.

( )Mais de 3 anos

( )Não possuo experiência.

6. Você possui experiência na Educação Especial?

(.) Até um ano.

Entre 1 e 3 anos.

Mais de 3 anos.

$\varangle$ Não possuo experiência

locê recebe da direção da escola informações/materiais sobre como trabalhar com

locê recebe da direção
los com deficiência?

ISim, recebo da direção todo o material necessário.

I Sim, recebo da coordenação todo o material necessário

$\curvearrowleft$ ) Sim, porém o que recebo da coordenação/direção não é suficiente.

) Não recebo, porém busco essas informações/materiais por conta própria.

Z. não recebo e não busco tais informações/materiais.

¿ omo você avalia a sua relação com

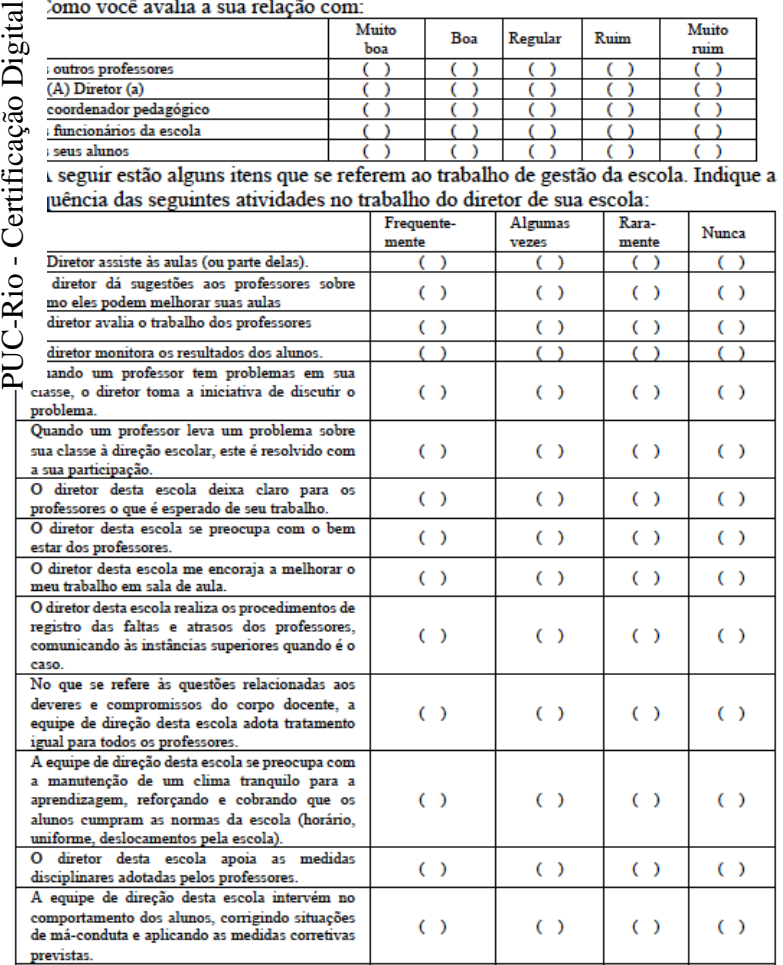

10. As interações pessoais que tive com o diretor, no último mês, foram predominantemente para (escolha apenas uma opção):

( ) Relatar trabalhos desenvolvidos em minha aula/turma, sobre os quais gostaria de conversar com o diretor.

( ) Apresentar e comentar os resultados de meus alunos nas últimas avaliações

( ) Resolver alguma situação disciplinar ou de comportamento ocorrido com meus alunos, para a qual solicitei a intervenção do diretor.

( ) Conversar sobre assuntos pessoais e diversos.

( ) Resolver alguma situação administrativa

11. Como você avalia os seguintes aspectos da sua escola:

\begin{tabular}{|c|c|c|c|c|c|}
\hline & $\begin{array}{c}\text { Muito } \\
\text { boa }\end{array}$ & Boa & Regular & Ruim & $\begin{array}{l}\text { Muito } \\
\text { rum }\end{array}$ \\
\hline A convivência entre as pessoas & $(1)$ & $(1)$ & $(1)$ & $(1)$ & $(1)$ \\
\hline Disciplina/comportamento dos alunos & (1) & (c) & (1) & ( ) & (1) \\
\hline Relaçẫo dos professores com os alunos & $(1)$ & (1) & $(1)$ & (1) & $(1)$ \\
\hline $\begin{array}{l}\text { Relacão entre os professores de una forma } \\
\text { geral }\end{array}$ & ( ) & ( ) & ( ) & ( ) & ( ) \\
\hline $\begin{array}{l}\text { Relacãão entre os professores e a } \\
\text { coordenaçâo pedagogogica }\end{array}$ & ( ) & ( ) & ( ) & ( ) & ( ) \\
\hline Relação entre os professores e a direção & ( ) & ( ) & ( ) & ( ) & ( ) \\
\hline Relação entre os alunos e os funcionánios & 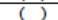 & & & & (1) \\
\hline
\end{tabular}

12. Indigue o seu nivel de concordância com cada uma das afirmativas abaixo:

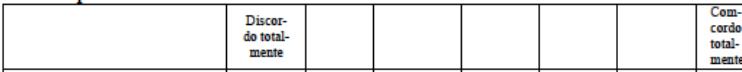

Nesta escola a equipe
gestão é reconhecida

realizar um bom trabalho.

Em equipe, trabalhamos para
melhorar a imagem da escola.

\begin{tabular}{l|l|l|l|l|l|l} 
( ) & $($ ) & ( ) & ( ) & ( ) & ( ) & ( )
\end{tabular}

tamanho da minha turma.

\begin{tabular}{ll|l|l|l|l|l}
$(1)$ & $(1)$ & $(1)$ & $(1)$ & $(1)$ & $(1)$ & $(1)$
\end{tabular}

tempo dar o melhor de mim

Eu me sinto satisfeito en

trabalhar nesta escola.

A equipe de gestão da escola

tem uma postura

os professores.

\begin{tabular}{ll|l|l|l|l|l|l} 
reforça $\circ$ trabalho & & & & & & & \\
\hline
\end{tabular}

desenvolvido pelos

professores.
0 diretor desta escola

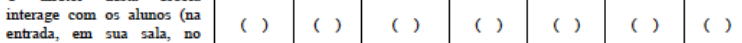

ra sala,

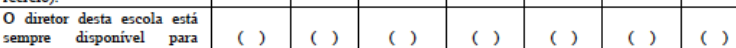

atender quem o procurar.

O diretor desta esco

\begin{tabular}{ll|l|l|l|l|l|l}
$\begin{array}{l}\text { demonstra abertura } \\
\text { interesse para escutar }\end{array}$ os & ( ) & ( ) & ( ) & ( ) & ( ) & ( ) & ( )
\end{tabular}

professores para escutar os

o diretor desta escola

\begin{tabular}{l|l|l|l|l|l|l|l}
$\begin{array}{l}\text { consegue articular as } \\
\text { diferentes ideias e opiniôes }\end{array}$ & ( ) & ( ) & ( ) & ( ) & ( ) & ( ) & ( )
\end{tabular}

do grupo.

Sinto-me realizado com o
trabalho que desenvolvo

nesta escola.

inclusiva

Encontro na escola

infraestrutura que preciso

para realizar minhas aulas.

A organização da es
favorece meu trabalho.

Há um senso de cooperaçã̃

nesta escola.

( ) $\operatorname{Sim}($ ) Não

Registre os motivos que o/a levaram a esta decisão:

14.Quantos alunos com deficiência desta escola você acredita que chegarão à universidade?

( ) Todos ou quase todos

( ) Um pouco mais da metade.

( ) Um pouco menos da metade

( ) Muito poucos 


\section{6}

\section{Pesquisa: "GESTÃO DA ESCOLA, CLIMA ESCOLAR E DESEMPENHO DOS ALUNOS: QUAIS AS RELAÇÕES?"}

15. Qual a expectativa da escola em relação ao(s) aluno(s) com deficiência matriculado(s) atualmente:

( ) Que o(s) aluno(s) acompanhe(m) a turma acompanhe toda a turma.

( ) Que ele não acompanhe os conteúdos, mas tenha a oportunidade de socialização. ( ) Acredito que o aprendizado no caso desses alunos não seja possivel

16. Você é: a. () Homem; b. ( ) Mulher.

17. Marque a opção que determina a sua faixa etária:
$\begin{array}{ll}\text { ( ) Até } 24 \text { anos. } & \text { ( ) De } 40 \text { a } 49 \text { anos. }\end{array}$

( ) Até 24 anos.

() De 40 a 49 anos
() 50 anos

( ) De 30 a 39 anos.

( ) 55 anos ou mais

18. Qual é o seu grau máximo de escolarização concluída?

( ) ensino fundamental

( ) ensino médio

( ) curso normal de nivel médio

( ) ensino médio técnico

( ) curso normal de nivel superior.

( ) ensino superior.

( ) ensino superior.

( ) mestrado.

( ) doutorado

( ) pós-doutorado

19. Qual é o seu regime de trabalho nesta escola?

( ) concursado.

( ) contrato temporário

20. Caso tenha feito ensino superior, em que tipo de instituição se graduou?

( ) pública

( ) privada

( ) pedagogia

( ) outra licenciatura

( ) outros.

22. Há quantos anos (completos) você é professor nesta escola?

( ) Menos de 1 ano.

no. ( ) 7 a 9 anos.

( ) 10 a 14 anos.

( ) 4 a 6 anos ( ) Mais de 15 anos.
23. Há quantos anos (completos) você é professor nesta rede de ensino?

$\begin{array}{lll}\text { ( ) Menos de } 1 \text { ano. ( ) } 7 \text { a } 9 \text { anos. } & \text { ( ) } 10 \text { a } 14 \text { anos. }\end{array}$

$\begin{array}{ll}\text { ( ) } 1 \text { a } 3 \text { anos. } & \text { ( ) } 10 \text { a } 14 \text { anos }\end{array}$

( ) 4 a 6 anos. ( ) Mais de 15 anos

24. Quais disciplinas você leciona atualmente nesta escola?

( ) Todas as disciplinas (professor polivalente dos anos iniciais do ensino fundamental/Educação Infantil).

( ) Lingua Portuguesa (anos finais do ensino fundamental).

( ) Matemática (anos finais do ensino fundamental).

( ) Outras. Especifique:

25. Qual a sua carga horária semanal de trabalho nesta escola?
$\begin{array}{llll}\text { ( ) até } 20 \mathrm{~h} & (\mathrm{)}) \text { até } 30 . & (\text { ) até } 40 \mathrm{~h} . & (\text { ) mais de } 40 \mathrm{~h} .\end{array}$

26. De que forma você foi alocado nesta escola?

( ) indicação da Secretaria.

( ) minha solicitação.

( ) solicitação do diretor

( ) realocação.

(27. Em sua jornada de trabalho nesta escola está prevista carga horária remunerada para a realização de reuniões pedagógicas?

( ) $\mathrm{Sim}$

( ) Sim.

28. Você possui outro cargo de professor?

( ) $\mathrm{Sim}$.

( ) Não.

29. Agradecemos a sua participação. Caso queira registrar algum comentário sobre este questionário ou acrescentar alguma informação que julgue importante, utilize o espaço abaixo: 


\section{Apêndice 5.}

Roteiro utilizado nas entrevistas durante a segunda fase da pesquisa:

- Qual a formação e trajetória profissional.

- Atuação na rede e na escola - tempo, acesso ao cargo/função, etc.

- Relação com o resto da equipe - como foram escolhidos.

- Principais atividades/responsabilidades da equipe

- São realizadas ações de formação na escola? Sobre que temas? Como são feitas?

- Critérios de atribuição de turmas aos professores

- Essa escola é inclusiva? Por que? Como?

- Como se identifica um aluno com deficiência e o que acontece nessas situações? 